UNIVERSIDADE DE SÃO PAULO

ESCOLA DE ENGENHARIA DE SÃO CARLOS

DEPARTAMENTO DE ENGENHARIA HIDRÁULICA E SANEAMENTO

LABORATÓRIO DE PROCESSOS BIOLÓGICOS

LEANDRO AUGUSTO GOUVÊA DE GODOI

Potencial do reator anaeróbio de leito fixo-estruturado e fluxo descendente para o tratamento de drenagem ácida de minas em co-digestão com vinhaça

VERSÃO CORRIGIDA

SÃO CARLOS

2018 



\title{
Potencial do reator anaeróbio de leito fixo-estruturado e fluxo descendente para $o$ tratamento de drenagem ácida de minas em co-digestão com vinhaça
}

\begin{abstract}
Tese apresentada à Escola de Engenharia de São Carlos, da Universidade de São Paulo, como parte dos requisitos para obtenção do título de Doutor em Ciências: Engenharia Hidráulica e Saneamento.
\end{abstract}

Orientadora: Prof ${ }^{a}$. Dr ${ }^{a}$. Márcia Helena Rissato Zamariolli Damianovic

\section{VERSÃO CORRIGIDA \\ SÃO CARLOS




\section{AUTORIZO A REPRODUÇÃO TOTAL OU PARCIAL DESTE TRABALHO POR QUALQUER MEIO ĆONVENCIONAL OU ELETRÔNICO, PARA FINS DE ESTUDO E PESQUISA, DESDE QUE CITADA A FONTE.}

Ficha catalográfica elaborada pela Biblioteca Prof. Dr. Sérgio Rodrigues Fontes da EESC/USP com os dados inseridos pelo(a) autor(a).

Gouvêa de Godoi, Leandro Augusto
G588p Potencial do reator anaeróbio de leito fixo-estruturado e fluxo descendente para o tratamento de drenagem ácida de minas em co-digestão com vinhaça / Leandro Augusto Gouvêa de Godoi; orientadora Márcia Helena Rissato Zamariolli Damianovic. São Carlos, 2018 .

Tese (Doutorado) - Programa de Pós-Graduação em Engenharia Hidráulica e Saneamento e Área de Concentração em Hidráulica e Saneamento -- Escola de Engenharia de São Carlos da Universidade de São Paulo, 2018 .

1. Drenagem ácida de minas. 2. bactérias redutoras de sulfato. 3. recuperação de metais. 4. sulfeto. 5. ferro. 6. vinhaça de cana-de-açúcar. 7. leito fixo-estruturado. 8. fluxo descendente. I. Título. 


\section{FOLHA DE JULGAMENTO}

Candidato: Engenheiro LEANDRO AUGUSTO GOUVÊA DE GODOI.

Título da tese: "Potencial do retor anaeróbio de leito fixo-estruturado e fluxo descendente para o tratamento de drenagem ácida de minas em codigestão com vinhaça".

Data da defesa: 14/05/2018.

Comissão Julaadora:

Resultado:

Profa. Dra. Márcia Helena Rissało Zamariolli Damianovic (Orieníadora)

(Escola de Engenharia de São Carlos/EESC)

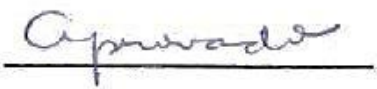

Prof. Titular Eugenio Foresti

(Escola de Engenharia de São Carlos/EESC)

ATROFADO

Prof. Dr. Arnaldo Sarii

Aprovaro

(Universidade Estadual Paulista "Júlio de Mesquita Filho"/UNESP - Araraquara)

Prof. Dr. Gunther Brucha

(Universidade Federal de Alfenas/UNIFAL)

APRCVADC

Profa. Dra. Sueli Moura Bertolino

APROVADO

(Universidade Federal de Uberlândia/UFU)

Coordenador do Programa de Pós-Graduação em Engenharia Hidráulica e Saneamento:

Prof. Dr. Eduardo Mario Mendiondo

Presidente da Comissão de Pós-Graduação:

Prof. Associado Luís Fernando Costa Alberto 



\section{DEDICATÓRIA}

A Natália, companheira para toda a vida, e à Helena, nossa amada filha, o melhor presente do mundo, dedico. 



\section{AGRADECIMENTOS}

A Deus, pela vida, pelas oportunidades concedidas e por sua presença misericordiosa ao meu lado, sustentando e iluminando meus passos a todo momento, fazendo-se sentir quando mais foi necessário.

Aos meus pais, José Carlos e Leila, a meu irmão Matheus, e à "Vó Lena", família maravilhosa, por todo incansável apoio, generosidade, pelos conselhos e, mais que tudo, por todo amor!

À Natália, minha amada esposa, por toda paciência e cumplicidade na aventura da vida, pela compreensão ao longo do difícil processo do doutorado e, acima de tudo, pelo nosso maior presente: Helena, nossa filha, que desde pequena tem nos possibilitado viver uma nova dimensão (incondicional) do amor!

A todos os meus demais familiares, junto dos quais a vida é sempre mais cheia de alegrias e forças para superar os desafios.

À Professora Márcia Damianovic, pela dedicada orientação e por todo suporte desde o mestrado, pela confiança em mim depositada e, principalmente, pela amizade.

Aos grandes Professores Eugenio Foresti e Marcelo Zaiat, pela valiosa convivência no LPB, pelas sugestões, pelos exemplos de profissionais e de seres humanos, e pela sabedoria compartilhada, especialmente nas indispensáveis horas do café. E à Professora Maria Bernadete, por seu comprometimento e zelo em manter os usuários do LPB "na linha”, sem o qual muito do sucesso desse grupo de pesquisa não teria sido alcançado.

Aos Professores Ariovaldo Silva e Renata Rodriguez, pela participação e pelas contribuições na qualificação do presente trabalho.

Aos Professores Arnaldo Sarti, Gunther Brucha e Sueli Bertolino, que ao lado do Prof. Eugenio Foresti aceitaram tomar parte na banca de avaliação deste trabalho.

Aos grandes amigos "panquecudos": Carla, Priscila, Carol-Gil, Isabella, Tiago, Lucas, Eduardo e Carol, Rachel e Fabrício, pela grande amizade e parceria construída ao longo da pós-graduação, por toda ajuda, pelos exemplos de dedicação, pelas conversas científicas, e pelas conversas não tão científicas assim, pelos apuros compartilhados, pela afinidade com nossos amigos de quatro-patas, e por toda a zoeira que tornou mais leve a nossa árdua rotina no laboratório. Levarei a amizade de vocês pela vida!

À Renata Solcia, pela dedicação no enfrentamento ao desafiador ciclo do enxofre. 
A todos os amigos do LPB, grande família da ciência que desde os tempos de iniciação tive o prazer de conhecer: Aimeé, Alana, Alejandra, Ana Flávia, Ânia, Beatriz Lyra, Bruno-Giz, Camila, Carol Granatto, Cebola, Cristiane Arruda, Dagoberto, Djalma, Drica, Elias, Elis, Fabrício, Fiaz, Gleisi, Guilherme Oliveira, Guilherme Soares, Inaê, Inês, Jéssica Lopes, Juliana Kawanishi, Kiemi, Laís, Leonardo (Sr. Léo), Luma, Mara, Marcus, Mariê, Marina, Maritza, Mirabelle, Mirian, Moara, Paulo Clair, Pilar, Rachel Lebrero, Raissa, Ricardo Almeida, Rodrigo Carneiro, Rodrigo Longo, Rogério, Sarah, Samuel, Simone, Tainá, Taís, Tânia, Theo, Tiagão, Túlio, Valéria Del Nery, Vanessa, Vivian, Vuitik... E a todos os que não tenham sido mencionados...

À Janja e Carol Sabatini, pelo auxílio na execução das técnicas cromatográficas, pelo suporte na sala de análises e no laboratório como um todo, bem como pela agradável convivência diária. À Isabel, pela ajuda na realização do DGGE, à Elô, pelas microscopias efetuadas, e a ambas pelo auxílio na sala da microbiologia. Ao técnico do IQSC, Márcio de Paula, pela competência na realização das análises de EDX.

Aos funcionários do departamento de Hidráulica e Saneamento: Silvana, Fernando, Rose, Sá, Priscila, e a todo o corpo técnico. Também ao Sr. Antônio, Dona Rosa, Dona Fátima e Andréia, e a todos os responsáveis pela segurança e limpeza do laboratório.

Aos demais amigos, que acompanharam minha trajetória até aqui, especialmente aos irmãos que ganhei pela fé na Paróquia São Benedito (São Carlos/SP), por todo apoio, incentivo, torcida e pela partilha da vida. Seria impossível nomear a cada um!

Ao time Ergostech: Yumi e Lívia, por acreditarem no meu trabalho. À Bruna, Alan, Weslei e Wivi, pela acolhida e por acompanharem de perto os apuros para finalizar esta tese.

À Alexandra Elbakyan, e a toda equipe por trás da plataforma "Sci-Hub", pela luta em favor da ampla disseminação e livre acesso ao conhecimento científico.

Ao CNPq, pela concessão da bolsa que tornou possível a realização deste trabalho.

E a todos os que, de alguma forma, contribuíram para a minha formação acadêmica, profissional, pessoal e para a finalização desta tese... 
"A natureza tem perfeições para mostrar que é a imagem de Deus, e defeitos para mostrar que é apenas sua imagem."

Blaise Pascal (1623-1662) 



\section{RESUMO}

GODOI, L.A.G. Potencial do reator anaeróbio de leito fixo-estruturado e fluxo descendente para o tratamento de drenagem ácida de minas em co-digestão com vinhaça. 2018. 256 p. Tese (Doutorado) - Escola de Engenharia de São Carlos, Universidade de São Paulo, São Carlos, 2018.

No presente trabalho foi avaliado o potencial do reator anaeróbio de leito fixo-estruturado e fluxo descendente (down-flow fixed strucutured bed reactor - DFSBR) para o tratamento de drenagens ácidas de minas (DAM) com vistas à recuperação de metais. Vinhaça de cana-deaçúcar foi utilizada como doador de elétrons para bactérias redutoras de sulfato (BRS) e ferro $\left(\mathrm{Fe}^{2+}\right)$ foi adicionado como metal de referência. Em associação com a sulfetogênese, produção de metano foi promovida pela relação $\mathrm{DQO} / \mathrm{SO}_{4}{ }^{2-}$ de 2,0 , maior que a relação estequiométrica de oxidação da matéria orgânica via redução de $\mathrm{SO}_{4}{ }^{2-}(0,67)$. Concentrações afluentes de DQO e $\mathrm{SO}_{4}{ }^{2-}$ da ordem de $4000 \mathrm{mg} . \mathrm{L}^{-1}$ e $2000 \mathrm{mg} . \mathrm{L}^{-1}$, respectivamente, foram mantidas durante todo o período experimental (547 dias), sendo o reator operado com TDH de $20 \mathrm{~h}$. Durante a ETAPA 1 (277 dias) o DFSBR foi alimentado com substrato sintético simulando a fração solúvel da vinhaça e recebeu cargas crescentes de ferro $\left(0,07\right.$ a $\left.0,51 \mathrm{~g} \mathrm{Fe}^{2+} \cdot \mathrm{L}^{-1} \cdot \mathrm{d}^{-1}\right)$ para avaliação do potencial de remoção de metais. Foram obtidas eficiências de remoção de DQO e $\mathrm{SO}_{4}{ }^{2-}$ de $94 \pm 2 \%$ e $97 \pm 3 \%$, respectivamente. Remoção de ferro de $95 \pm 5 \%$ foi alcançada, assim como proporções crescentes de ferro (de até 55\%) nas cinzas do precipitado. Ao longo da ETAPA 2 (100 dias) vinhaça foi utilizada como único doador de elétrons e diferentes razões de recirculação foram estudadas $(0,50,100$ e 150 vezes $)$, com velocidades superficiais do escoamento variando de 0,03 a 5,20 m. $\mathrm{h}^{-1}$. A eficiência de remoção de DQO de $82 \pm 6 \%$ foi atribuída à presença de compostos recalcitrantes na vinhaça, ao passo que a remoção de $\mathrm{SO}_{4}{ }^{2-}$

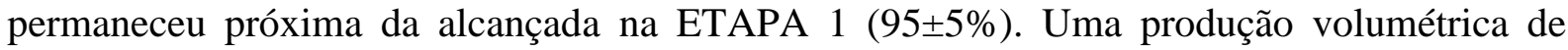
metano da ordem de $390 \mathrm{~mL} \mathrm{CH}_{4} \cdot \mathrm{L}^{-1} \cdot \mathrm{d}^{-1}$ foi obtida (CNTP). A despeito da variação nas taxas de reciclo, maior estabilidade e eficiência de remoção de ferro $(96 \pm 3 \%)$ foram determinadas na ausência de recirculação, com ganhos econômicos para o processo. Durante a ETAPA 3 (170 dias) a diminuição gradativa do $\mathrm{pH}$ afluente de 6,30 para 3,50 foi realizada. Apesar da supressão de alcalinidade, o sistema atingiu eficiências de remoção de $\mathrm{SO}_{4}{ }^{2-}$ de $97 \pm 1 \%$ e remoção de ferro de $95 \pm 4 \%$. Foram observados efeitos adversos sobre o metabolismo metanogênico, com queda na produção de metano de 380 para $230 \mathrm{~mL} \quad \mathrm{CH}_{4} \cdot \mathrm{L}^{-1} \cdot \mathrm{d}^{-1}$, acompanhada por aumento da DQO residual no efluente (1500 mg DQO.L $\mathrm{L}^{-1}$ ). Ainda assim, o DSFBR foi capaz de elevar o $\mathrm{pH}$ da água residuária de 3,5 para 6,9, confirmando o potencial do sistema para a neutralização de DAM. A caracterização da comunidade microbiana por análise do sequenciamento do gene RNAr $16 \mathrm{~S}$ indicou predominância dos gêneros Desulfovibrio e Methanosaeta, comprovando o estabelecimento simultâneo dos processos sulfetogênicos e metanogênicos. Por fim, os resultados apontaram perspectivas promissoras de aplicação do DFSBR ao tratamento de DAM via redução de $\mathrm{SO}_{4}{ }^{2-}$ favorecendo a precipitação e separação de metais em reator de único estágio. A vinhaça de cana-de-açúcar também se mostrou um adequado doador de elétrons para o processo.

Palavras-chave: Drenagem ácida de minas; bactérias redutoras de sulfato; recuperação de metais; sulfeto; ferro; vinhaça de cana-de-açúcar; leito fixo-estruturado; fluxo descendente. 


\begin{abstract}
GODOI, L.A.G. Down-flow fixed-structured bed anaerobic reactor potential for acid mine drainage treatment in co-digestion with vinasse. 2018. 256 p. Tese (Doutorado) Escola de Engenharia de São Carlos, Universidade de São Paulo, São Carlos, 2018.
\end{abstract}

This work evaluated the potential of the down-flow fixed-structured bed anaerobic reactor (DFSBR) for the treatment of acid mine drainage (AMD) aiming at metals recovery. Sugarcane vinasse was used as electron donor for sulfate-reducing bacteria (BRS) and iron $\left(\mathrm{Fe}_{2}{ }^{+}\right)$was added as reference metal. In association with sulfidogenesis, methane production was promoted by the applied $\mathrm{COD} / \mathrm{SO}_{4}{ }^{2-}$ ratio of 2.0 , which is higher than the stoichiometric ratio for organic matter oxidation solely by $\mathrm{SO}_{4}{ }^{2-}$ reduction (0.67). Affluent concentrations of $\mathrm{COD}$ and $\mathrm{SO}_{4}{ }^{2-}$ were kept close to $4000 \mathrm{mg} . \mathrm{L}^{-1}$ and $2000 \mathrm{mg} . \mathrm{L}^{-1}$, respectively, over the entire experimental time (547 days). The reactor was operated with HRT of $20 \mathrm{~h}$. During STAGE 1 (277 days) the DFSBR was fed with synthetic substrate simulating the soluble fraction of vinasse and received increasing iron loads $\left(0.07\right.$ to $\left.0.51 \mathrm{~g} \mathrm{Fe}^{2+} \cdot \mathrm{L}^{-1} \cdot \mathrm{d}^{-1}\right)$ to verify the potential for metal removal. $\mathrm{COD}$ and $\mathrm{SO}_{4}{ }^{2-}$ removal efficiencies were $94 \pm 2 \%$ and $97 \pm 3 \%$, respectively. Iron removal of $95 \pm 5 \%$ was achieved, as well as increasing proportions of iron (up to 55\%) were observed in the ashes of precipitate. Throughout STAGE 2 (100 days) sugarcane vinasse was used as unique electron donor whereas different recirculation ratios were studied $(0,50,100$ and 150 times), with superficial flow velocities ranging from 0.03 to $5.20 \mathrm{~m}^{-1}$. COD removal efficiency of $82 \pm 6 \%$ was attributed to the presence of recalcitrant compounds in the vinasse, while the removal of $\mathrm{SO}_{4}{ }^{2-}$ remained close to that previously achieved during STAGE $1 \quad(95 \pm 5 \%)$. Volumetric methane production near of $390 \mathrm{~mL} \mathrm{CH} 4 . \mathrm{L}^{-1} \cdot \mathrm{d}^{-1}$ was obtained (STP). Although the variation in the recycle rates, greater stability and efficiency of iron removal $(96 \pm 3 \%)$ were determined in the absence of recirculation, with economic gains for the process. During the STAGE 3 (170 days) gradual decrease of the $\mathrm{pH}$ affluent from 6.30 to 3.50 was performed. Despite the alkalinity suppression, the system achieved $\mathrm{SO}_{4}{ }^{2-}$ removal efficiencies of $97 \pm 1 \%$ and iron removal close to $95 \pm 4 \%$. Adverse effects over methanogenic metabolism were observed once methane production decreased from 380 to $230 \mathrm{~mL} \mathrm{CH}_{4} \cdot \mathrm{L}^{-1} \cdot \mathrm{d}^{-1}$, which was followed by a residual COD increase in the effluent (1500 mg COD.L $\left.{ }^{-1}\right)$. Nevertheless, the DSFBR was able to raise the $\mathrm{pH}$ of the wastewater from 3.5 to 6.9 , indicating the potential of such system for AMD neutralization. 16S rRNA gene sequencing analysis for microbial community characterization showed predominance of the genera Desulfovibrio and Methanosaeta, confirming the simultaneous establishment of sulfidogenic and methanogenic processes. Finally, the results presented promising perspectives for the DFSBR application to the AMD treatment via $\mathrm{SO}_{4}{ }^{2-}$ reduction, also favoring metals precipitation and separation in a single-stage reactor. Sugarcane vinasse was also considered a suitable electron donor for the process.

Keywords: Acid mine drainage; sulfate-reducing bacteria; metals recovery; sulfide; sugarcane vinasse; structured-fixed bed; down-flown. 


\section{LISTA DE FIGURAS}

Figura 3.1: Solubilidade de diversos sulfetos metálicos em função do $\mathrm{pH}$.

Figura 3.2: Solubilidade de hidróxidos metálicos em função do pH.

Figura 3.3: Distribuição das espécies de sulfeto em função do $\mathrm{pH}$ com destaque da faixa ótima para a digestão anaeróbia.

Figura 4.1: Representação esquemática do reator de leito fixo-estruturado de fluxo descendente (DFSBR) e vista transversal do leito.

Figura 4.2: Cilindros de polietileno de baixa densidade.

Figura 4.3: Hastes de material suporte do DFSBR.

Figura 4.4: Reator DFSBR em operação com indicação dos pontos de coleta de amostra. Detalhe para a zona de sedimentação sem material suporte.

Figura 4.5: Curva de calibração estabelecida para a análise espectrofotométrica de ferro total pelo método da Ferrozina.

Figura 4.6: (a) Representação esquemática do aparato utilizado para a geração de sulfeto de hidrogênio dissolvido, e (b) fotografia ilustrativa do sistema em uso.

Figura 5.1: Eficiências de remoção de DQO (ER-DQO) e sulfato (ER-Sulfato), e cargas volumétricas aplicadas de DQO (COVa) e sulfato (CSVa) ao longo da ETAPA 1, operada com as seguintes concentrações de ferro: FASE 1A - 2 mg.L - $^{-1}$ FASE 1B - 55 mg.. ${ }^{-1}$; FASE 1C - 110 mg.L ${ }^{-1}$; FASE $1 \mathrm{D}-220 \mathrm{mg} . \mathrm{L}^{-1}$ e FASE $1 \mathrm{E}-400 \mathrm{mg} . \mathrm{L}^{-1}$.

Figura 5.2. Desempenho geral do DFSBR: (a) Análise estatística de Boxplot das cargas orgânicas removidas (COVr) e eficiências médias de remoção de DQO durante a ETAPA 1; e (b) Análise estatística de Boxplot das cargas de sulfato removidas (CSVr) e eficiências médias de remoção de sulfato durante a ETAPA 1.

Figura 5.3. Distribuição do fluxo de elétrons no DFSBR (em porcentagem de DQO) para as vias de redução de sulfato, metanogênese e produção de sólidos suspensos voláteis (SSV) em cada fase da ETAPA 1. As barras de erros representam o desvio-padrão.

Figura 5.4. Concentrações de ácido acético (em termos de DQO) no efluente do reator DFSBR durante as fases operacionais da ETAPA 1. As barras de erro representam o desvio-padrão.

Figura 5.5. Concentrações de sulfeto total dissolvido, sulfeto de hidrogênio molecular $\left(\mathrm{H}_{2} \mathrm{~S}\right)$ e sulfeto ionizado $\left(\mathrm{HS}^{-}\right)$no efluente do reator DFSBR durante a ETAPA 1. As barras de erros representam o desvio-padrão. 
Figura 5.7. Pontos brancos são indícios de enxofre elementar acumulado em amostras de biomassa do reator ao final da primeira fase operacional.

Figura 5.8. Células com possível acúmulo de enxofre elementar.

Figura 5.9. Desempenho do DFSBR na remoção de ferro: (a) Análise estatística de Boxplot das eficiências de remoção de ferro obtidas nas FASES 1B a 1E; e (b) Análise estatística de Boxplot das cargas de ferro removidas e cargas de ferro médias aplicadas durante a ETAPA 1. 121

Figura 5.10. Monitoramento temporal das eficiências de remoção de ferro ao longo da ETAPA 1. Setas em destaque indicam realização de descartes de fundo no DFSBR. 122

Figura 5.11. Análise do material precipitado: (a) Concentrações de sólidos totais, fixos e voláteis nas amostras de descarte em cada fase da ETAPA 1; e (b) Caracterização elementar por EDX das cinzas do material coletado. As barras de erro representam o desvio-padrão.

Figura 5.12: Análise estatística de Boxplot da produção volumétrica de metano da ETAPA 1. Dados corrigidos para as $\mathrm{CNTP}\left(0^{\circ} \mathrm{C}\right.$ e $\left.1 \mathrm{~atm}\right)$.

Figura 5.13: Morfologias semelhantes ao gênero Methanosaeta em amostras de biomassa do reator DFSBR ao final da primeira fase operacional. 128

Figura 5.14: Morfologias semelhantes às de bactérias redutoras de sulfato. 129

Figura 5.15: Dendrogramas baseados no coeficiente de similaridade de Pearson a partir do padrão de bandas do DGGE encontrado no inóculo (IN-1) e em amostras de biomassa coletadas ao final das FASES 1A e 1E para os Domínios Archaea (a) e Bacteria (b). 130

Figura 5.16. Alcalinidade a sulfeto em diversos níveis de concentração de sulfeto total dissolvido (STD) e valores de $\mathrm{pH}$ dentro da faixa usual para a digestão anaeróbia $(5,0<\mathrm{pH}<9,0)$. 140

Figura 5.17. Características do efluente do DFSBR com relação às frações de alcalinidade total devidas a sulfeto, a bicarbonato e a ácidos voláteis durante a ETAPA 1. As barras de erros representam o desvio-padrão.

Figura 5.18. Resultados dos ensaios hidrodinâmicos: (a) Curvas de resposta normalizadas obtidas (curvas F originais); (b) Curvas de resposta ajustadas (curvas F ajustadas); e (c) Curvas de distribuição do tempo de residência (curvas E).

Figura 5.19. Fotografias mostrando a injeção de dextrana azul no DFSBR: (a) Logo após o pulso; (b) após $6 \mathrm{~h}$ do pulso; e (c) após $24 \mathrm{~h}$. As imagens receberam tratamento digital para melhor visualização da zona estagnada (em azul). 152

Figura 5.20. Eficiências de remoção de DQO (ER-DQO) e sulfato (ER-Sulfato), e cargas volumétricas aplicadas de matéria orgânica (COVa) e sulfato (CSVa) ao longo do tempo de operação da ETAPA 2, sob diferentes razões de recirculação. 155

Figura 5.21. Desempenho geral do DFSBR: (a) Análise estatística de Boxplot das cargas orgânicas removidas (COVr) e eficiências médias de remoção de DQO durante a ETAPA 2; e (b) Análise 
estatística de Boxplot das cargas de sulfato removidas (CSVr) e eficiências médias de remoção de sulfato durante a ETAPA 2.

Figura 5.22. Concentrações de ácido acético (em termos de DQO) no efluente do reator DFSBR durante as fases operacionais da ETAPA 2. As barras de erro representam o desvio-padrão. ............ 158

Figura 5.23. Distribuição do fluxo de elétrons no DFSBR (em porcentagem de DQO) para as vias de redução de sulfato, metanogênese e produção de sólidos suspensos voláteis (SSV) em cada fase da ETAPA 2. As barras de erros representam o desvio-padrão. 160

Figura 5.24. Análise do lodo aderido ao material suporte: (a) Concentrações de sólidos totais, fixos e voláteis em cada fase da ETAPA 2; e (b) Caracterização elementar por EDX das cinzas do material coletado. As barras de erro representam o desvio-padrão.

Figura 5.25. Características do efluente do DFSBR com relação às frações de alcalinidade total devidas a sulfeto, a bicarbonato e a ácidos voláteis durante a ETAPA 2. As barras de erros representam o desvio-padrão. 166

Figura 5.26: Frações de sulfeto produzidas pelo reator DFSBR ao longo da ETAPA 2 167

Figura 5.27. Concentrações de sulfeto total dissolvido, sulfeto de hidrogênio molecular $\left(\mathrm{H}_{2} \mathrm{~S}\right)$ e sulfeto ionizado ( $\mathrm{HS}^{-}$) no efluente do reator DFSBR durante a ETAPA 2. As barras de erros representam o desvio-padrão. 168

Figura 5.28: Análise estatística de Boxplot da produção volumétrica de metano da ETAPA 2. Dados corrigidos para as $\mathrm{CNTP}\left(0^{\circ} \mathrm{C}\right.$ e $\left.1 \mathrm{~atm}\right)$. 170

Figura 5.29. Desempenho do DFSBR na remoção de ferro: (a) Análise estatística de Boxplot das eficiências de remoção de ferro obtidas nas FASES 2B a 2E; e (b) Análise estatística de Boxplot das cargas de ferro removidas e cargas de ferro médias aplicadas durante a ETAPA 2. 172

Figura 5.30. Correlação entre as cargas volumétricas de ferro aplicadas e removidas no DFSBR sob diferentes razões de recirculação ao longo das três ETAPAS de operação. 175

Figura 5.31. Análise do material precipitado: (a) Concentrações de sólidos totais, fixos e voláteis nas amostras de descarte em cada fase da ETAPA 2; e (b) Caracterização elementar por EDX das cinzas do material coletado. As barras de erro representam o desvio-padrão.

Figura 5.32. Perfis longitudinais de concentração de DQO (a) e sulfato (b) no DFSBR ao final das FASES 2B a $2 \mathrm{C}$. 178

Figura 5.33. Perfis longitudinais de concentração de sulfeto total e ferro total no DFSBR ao final das FASES 2B $(100 \mathrm{x}), 2 \mathrm{C}(0 \mathrm{x}), 2 \mathrm{D}(150 \mathrm{x})$ e $2 \mathrm{E}(50 \mathrm{x})$. 179

Figura 5.34: Dendrogramas baseados no coeficiente de similaridade de Pearson a partir do padrão de bandas do DGGE encontrado nos inóculos (IN-1 e IN-2) e em amostras de biomassa coletadas ao final das FASES 2A, 2B e 2E para os Domínios Archaea (a) e Bacteria (b). 
Figura 5.35. Decaimento temporal das concentrações medidas de DQO e sulfato em cada ensaio em batelada. As linhas representam os correspondentes ajustes matemáticos. As barras de erro verticais representam um desvio padrão sistemático estimado em $10 \%$.

Figura 5.36: Eficiências de remoção de DQO (ER-DQO) e sulfato (ER-Sulfato), e cargas volumétricas aplicadas de matéria orgânica (COVa) e sulfato (CSVa) ao longo da ETAPA 3, operada com diminuição gradual do $\mathrm{pH}$ afluente.

Figura 5.37. Desempenho geral do DFSBR: (a) Análise estatística de Boxplot das cargas orgânicas removidas (COVr) e eficiências médias de remoção de DQO durante a ETAPA 3; e (b) Análise estatística de Boxplot das cargas de sulfato removidas (CSVr) e eficiências médias de remoção de sulfato durante a ETAPA 3.

Figura 5.38. Distribuição do fluxo de elétrons no DFSBR (em porcentagem de DQO) para as vias de redução de sulfato, metanogênese e produção de sólidos suspensos voláteis (SSV) em cada fase da ETAPA 3. As barras de erros representam o desvio-padrão. 198

Figura 5.39: Análise estatística de Boxplot da produção volumétrica de metano da ETAPA 3. Dados corrigidos para as $\mathrm{CNTP}\left(0^{\circ} \mathrm{C}\right.$ e $\left.1 \mathrm{~atm}\right)$. 200

Figura 5.40: Perfis espaciais de $\mathrm{pH}$ ao longo do leito do reator DFSBR realizados ao final 202

Figura 5.41. Características do efluente do DFSBR com relação às frações de alcalinidade total devidas a sulfeto, a bicarbonato e a ácidos voláteis durante a ETAPA 3. As barras de erros representam o desvio-padrão. 203

Figura 5.42. Monitoramento da relação Ai/Ap ao longo do tempo operacional da ETAPA 3..... 204

Figura 5.43. Concentrações de ácido acético (em termos de DQO) no efluente do reator DFSBR durante as fases operacionais da ETAPA 3. As barras de erro representam o desvio-padrão. 206

Figura 5.44. Concentrações de sulfeto total dissolvido, sulfeto de hidrogênio molecular $\left(\mathrm{H}_{2} \mathrm{~S}\right)$ e sulfeto ionizado (HS ${ }^{-}$) no efluente do reator DFSBR durante a ETAPA 3. As barras de erros representam o desvio-padrão. 208

Figura 5.45. Monitoramento temporal das eficiências de remoção de ferro ao longo da ETAPA 3... 209

Figura 5.46: Frações de sulfeto produzidas pelo reator DFSBR ao longo da ETAPA 3. 211

Figura 5.47. Análise do material precipitado: (a) Concentrações de sólidos totais, fixos e voláteis nas amostras de descarte em cada fase da ETAPA 3; e (b) Caracterização elementar por EDX das cinzas do material coletado. As barras de erro representam o desvio-padrão. 213

Figura 5.48: Dendrogramas baseados no coeficiente de similaridade de Pearson a partir do padrão de bandas do DGGE encontrado nos inóculos (IN-1 e IN-2) e em amostras de biomassa coletadas ao final das FASES 3A, 3B, 3E e 3G para os Domínios Archaea (a) e Bacteria (b).

Figura 5.49: Curvas de rarefação definidas para os níveis de gênero e família das amostras 3A e 3G (a) e curvas de rarefação para as comunidades dos Domínios Archaea (b) e Bacteria (c). 
Figura 5.50: Abundâncias relativas referentes aos níveis taxonômicos de Domínio e Filo nas amostras sequenciadas ao final das FASES $3 \mathrm{~A}$ e $3 \mathrm{G}$ do DFSBR.

Figura 5.51. Abundâncias relativas de gêneros dos Domínios Bacteria (a) e Archaea (b) observadas nas amostras de biomassa do DFSBR ao final das FASES 3A e 3G. 


\section{LISTA DE TABELAS}

Tabela 3.1: Composições de DAM provenientes de minerações localizadas em municípios brasileiros.

Tabela 4.1: Condições operacionais empregadas ao longo das etapas do estudo

Tabela 4.2: Composições das soluções estoque e dosagem dos diversos componentes utilizados no preparo da vinhaça sintética. 70

Tabela 4.3: Soluções estoque de vitaminas e micronutrientes utilizadas na suplementação do substrato sintético.

Tabela 4.4: Composição final do efluente sintético utilizado durante a ETAPA 1 simulando a mistura de vinhaça com DAM rica em ferro.

Tabela 4.5: Composição original da vinhaça concentrada utilizada durante as ETAPAS 2 e 3 do

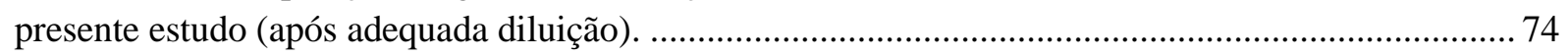

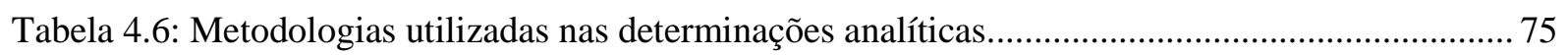

Tabela 4.7: Condições utilizadas no programa de PCR para os Domínios Archaea e Bacteria. .95

Tabela 5.1. Cargas orgânicas volumétricas aplicadas (COVa) e removidas (COVr), cargas de sulfato volumétricas aplicadas (CSVa) e removidas (CSVr) e eficiências de remoção de DQO (ER-DQO) e sulfato (ER-Sulfato) obtidas durante a ETAPA 1. 109

Tabela 5.2. Cargas volumétricas de ferro aplicadas (CFVa) e removidas (CFVr), e eficiências de remoção de ferro total (ER-Fe) durante a ETAPA 1.

Tabela 5.3. Alcalinidades total $\left(\mathrm{A}_{\mathrm{T}}\right)$, parcial $\left(\mathrm{A}_{\mathrm{P}}\right)$, intermediária $\left(\mathrm{A}_{\mathrm{I}}\right)$, a bicarbonato $\left(\mathrm{A}_{\mathrm{BIC}}\right)$ e devida a sulfeto ( $\left.\mathrm{A}_{\mathrm{HS}-}\right)$ nas soluções padrões.

Tabela 5.4. Dinâmica das frações de alcalinidade devida a sulfeto e a bicarbonato após a adição de ácido acético (titulações realizadas com $\mathrm{H}_{2} \mathrm{SO}_{4} 0,12 \mathrm{~N}$ ). 138

Tabela 5.5. Valores médios e desvios-padrões das concentrações de ferro afluente, HS , alcalinidade total e $\mathrm{pH}$ no efluente do reator DFSBR

Tabela 5.6. Ajustes matemáticos das curvas de resposta obtidas. 150

Tabela 5.7. Características do escoamento no DFSBR sob diferentes razões de recirculação. 151

Tabela 5.8. Cargas orgânicas volumétricas aplicadas (COVa) e removidas (COVr), cargas de sulfato volumétricas aplicadas (CSVa) e removidas (CSVr) e eficiências de remoção de DQO (ER-DQO) e sulfato (ER-Sulfato) obtidas durante a ETAPA 2 . 156

Tabela 5.9. Concentrações de SSV medido no efluente do DFSBR durante a ETAPA 2. 161 
Tabela 5.10. Cargas volumétricas de ferro aplicadas (CFVa) e removidas (CFVr), e eficiências de remoção de ferro total (ER-Fe) durante a ETAPA 2.

Tabela 5.11. Parâmetros obtidos para ajuste dos modelos cinéticos de primeira ordem com residual e sem residual, relativos à remoção de DQO e sulfato, respectivamente

Tabela 5.12. Cargas orgânicas volumétricas aplicadas (COVa) e removidas (COVr), cargas de sulfato volumétricas aplicadas (CSVa) e removidas (CSVr) e eficiências de remoção de DQO (ER-DQO) e sulfato (ER-Sulfato) obtidas durante a ETAPA 3.

Tabela 5.13. Valores de pH nas correntes afluente e efluente do DFSBR e no meio líquido interno, bem como concentrações de SSV medidas no efluente do reator durante a ETAPA 3.

Tabela 5.14. Variação na composição média do biogás do DFSBR durante a ETAPA 3.

Tabela 5.15. Cargas volumétricas de ferro aplicadas (CFVa) e removidas (CFVr), e eficiências de remoção de ferro total (ER-Fe) durante a ETAPA 3

Tabela 5.16. Resultados do sequenciamento e índices ecológicos $\alpha$ das amostras de biomassa obtidas ao final das FASES 3A e 3G

Tabela 5.17. Potencial de produção de energia a partir do biogás gerado no DFSBR tratando DAM utilizando vinhaça como doador de elétrons. 


\section{LISTA DE ABREVIATURAS, SIGLAS E SÍMBOLOS}

AAV: Alcalinidade devida a ácidos voláteis;

$\mathrm{Ag}^{2+}$ : Íon prata;

AHS: Alcalinidade devida a sulfeto;

AM: Arqueias metanogênicas;

ANOVA: Analysis of variance (Análise de Variância);

Ap: Alcalinidade parcial;

Ar: Argônio;

$\mathrm{A}_{\mathrm{T}}$ : Alcalinidade total;

BRS: bactérias redutoras de sulfato;

C: Concentração;

$\mathrm{CaCO}_{3}:$ Carbonato de cálcio

$\mathrm{Cd}^{2+}$ : Íon cádmio;

$\mathrm{CE}_{\mathrm{CH} 4}$ : Conteúdo energético do gás metano;

CFV: Carga de ferro volumétrica;

$\mathrm{CH}_{2} \mathrm{O}$ : Molécula orgânica genérica;

$\mathrm{CH}_{3} \mathrm{CH}_{2} \mathrm{CH}_{2} \mathrm{COO}^{-}$: Butirato;

$\mathrm{CH}_{3} \mathrm{CH}_{2} \mathrm{COO}^{-}$: Propionato;

$\mathrm{CH}_{3} \mathrm{CH}_{2} \mathrm{OH}$ : Etanol;

$\mathrm{CH}_{3} \mathrm{CHCOO}^{-}$: Lactato;

$\mathrm{CH}_{3} \mathrm{COO}^{-}$: Acetato;

$\mathrm{CH}_{3} \mathrm{COOH}$ : Ácido acético molecular;

$\mathrm{CH}_{4}$ : Metano;

$\mathrm{C}_{\mathrm{MÁX}}$ : Concentração máxima;

CNTP: Condições normais de temperatura e pressão;

$\mathrm{CO}_{2}$ : Dióxido de carbono;

$\mathrm{Co}^{2+}:$ Íon cobalto; 
COD: Chemical oxygen demand;

COV: Carga orgânica volumétrica;

CSV: Carga de sulfato volumétrica;

$\mathrm{Cu}^{2+}:$ Íon cobre;

DAM: Drenagem ácida de minas;

DFSBR: Down-flow fixed-structured bed reactor (Reator de leito fixo-estruturado e fluxo descendente);

DGGE: Denaturing gradient gel electrophoresis (Eletroforese em gel de gradiente desnaturante);

DNA: Deoxyribonucleic acid (Ácido desoxirribonucleico);

DBO: Demanda bioquímica de oxigênio;

DQO: Demanda química de oxigênio;

E (t): Curva de distribuição do tempo de residência;

EDS/EDX: Energy Dispersive Spectroscopy/Energy-dispersive X-ray spectroscopy

(Espectroscopia de raios X por dispersão em energia);

EESC: Escola de Engenharia de São Carlos;

ER-DQO: Eficiência de remoção de DQO;

ER-Fe: Eficiência de remoção de ferro total;

ER-Sulfato: Eficiência de remoção de sulfato;

F: Curva de resposta normalizada;

F: Estatística da Análise de Variância (ANOVA);

$\mathrm{Fe}(\mathrm{HS})_{2}$ : Hidrogenossulfeto de ferro;

$\mathrm{Fe}(\mathrm{OH})_{3}$ : Hidróxido de ferro;

$\mathrm{Fe}^{2+}:$ Íon ferroso;

$\mathrm{Fe}^{3+}:$ Íon férrico;

$\mathrm{FeCl}_{2} \cdot 4 \mathrm{H}_{2} \mathrm{O}$ : Cloreto de ferro (II) tetrahidratado;

FeS: Monossulfeto de ferro;

$\mathrm{FeS}_{2}$ : Dissulfeto de ferro (pirita);

Fi: Curva de resposta invertida (corrigida);

$\mathrm{H}^{+}$: Íon hidrogênio; 
$\mathrm{H}_{2}$ : Hidrogênio molecular;

$\mathrm{H}_{2} \mathrm{~S}$ : Sulfeto de hidrogênio molecular;

$\mathrm{H}_{2} \mathrm{SO}_{4}$ : Ácido sulfúrico;

$\mathrm{HCl}$ : Ácido clorídrico

$\mathrm{HCO}_{3}^{-}$: Íon bicarbonato;

$\mathrm{Hg}^{2+}$ : Íon mercúrio;

HRT: Hydraulic retention time (tempo de retenção hidráulico);

HS: : Íon bissulfeto (Hidrogenossulfeto);

$\mathrm{k}_{1:}$ Coeficiente cinético aparente de primeira ordem;

$\mathrm{k}_{1 \mathrm{sp}}$ : Coeficiente cinético aparente específico de primeira ordem;

$\mathrm{KCl}$ : Cloreto de potássio anidro;

$\mathrm{K}_{\mathrm{H}}$ : Constante de Henry;

Kps: Constante de solubilidade;

LPB: Laboratório de Processos Biológicos;

$\mathrm{Me}^{2+}:$ Íon metálico divalente genérico;

MeS: Molécula de um sulfeto metálico genérico;

N: Parâmetro do modelo de N-tanques de mistura em série;

$\mathrm{N}_{2}$ : Nitrogênio molecular;

$\mathrm{Na}_{2} \mathrm{HPO}_{4}$ : Fosfato de sódio bibásico;

$\mathrm{Na}_{2} \mathrm{~S} .9 \mathrm{H}_{2} \mathrm{O}$ : Sulfeto de sódio nonahidratado;

$\mathrm{Na}_{2} \mathrm{~S}$ : Sulfeto de sódio;

$\mathrm{Na}_{2} \mathrm{SO}_{4}$ : Sulfato de sódio anidro;

$\mathrm{NaCl}$ : Cloreto de sódio;

$\mathrm{NaH}_{2} \mathrm{PO}_{4}$ : Fosfato de sódio monobásico;

$\mathrm{NaHCO}_{3}$ : Bicarbonato de sódio;

$\mathrm{NaOH}$ : Hidróxido de sódio;

$\mathrm{Ni}^{2+}$ : Íon níquel;

NTK: Nitrogênio total kjeldahl; 
$\mathrm{O}_{2}$ : Oxigênio molecular;

$\mathrm{OH}^{-}$: Íon hidróxido;

OTU: Operational taxonomic unit (Unidade taxonômica operacional);

P.A.: Padrão analítico;

p: Nível de significância;

$\mathrm{Pb}^{2+}$ : Íon chumbo;

PBS: Phosphate buffered saline (Tampão fosfato-salino);

$\mathrm{P}_{\mathrm{CH} 4}$ : Pressão parcial de metano no headspace;

PCR: Polymerase chain reaction (Reação em cadeia da polimerase);

pH: Potencial hidrogeniônico;

$\mathrm{pKa}^{1}:$ Constante de primeira dissociação;

$\mathrm{pKa}^{2}:$ Constante de segunda dissociação;

$\mathrm{PO}_{4}{ }^{3-}$ : Íon fosfato;

PPE: Potencial de produção de energia a partir do biogás;

$\mathrm{Q}_{\mathrm{AFL}}$ : Vazão líquida afluente;

$\mathrm{Q}_{\mathrm{R}}$ : Vazão de recirculação da fase líquida;

$\mathrm{R}$ : Constante universal dos gases;

RAHLF: reator anaeróbio horizontal de leito fixo;

Rend $_{\mathrm{CH} 4}$ : Rendimento de metano por volume de vinhaça tratada;

RNA: Ribonucleic acid (Ácido ribonucleico);

RNAr: RNA ribossomal;

$S^{0}:$ Enxofre elementar;

$\mathrm{S}^{2-}:$ Íon dissulfeto;

SF: Sólidos fixos;

$\mathrm{SO}_{4}{ }^{2-}$ : Íon sulfato;

$\mathrm{SO}_{3}{ }^{2-}$ : Íon sulfito;

$\mathrm{S}_{2} \mathrm{O}_{3}{ }^{2-}$ : Íon tiossulfato;

SSV: Sólidos suspensos voláteis; 
STD: Sulfeto total dissolvido;

STE: Sulfeto total no efluente;

STF: Sólidos totais fixos;

STP: Standard temperature and pressure;

STV: Sólidos totais voláteis;

T: Temperatura experimental;

t: Tempo;

TDH: tempo de detenção hidráulica;

UASB: Upflow anaerobic sludge blanket reactor (Reator anaeróbio de fluxo ascendente com manta de lodo);

UPGMA: Unweighted Pair Group Method using Arithmetic averages (Método de agrupamento usando médias aritméticas não ponderadas);

USP: Universidade de São Paulo;

UV: Ultravioleta;

$\mathrm{V}_{\mathrm{CH} 4}$ : Vazão volumétrica de metano;

Vs: Velocidade superficial de escoamento;

Vt: Volume total;

Vu: Volume útil;

$\mathrm{X}_{\mathrm{CH} 4}$ : Concentração molar de metano dissolvido;

$\mathrm{Zn}^{2+}:$ Íon zinco;

$\mathrm{ZnSO}_{4}:$ Sulfato de zinco;

$\Delta \mathrm{G}^{\mathrm{o}}:$ Energia livre de Gibbs;

$\Delta \mathrm{t}$ : Intervalo de tempo;

$\varepsilon:$ Porosidade do leito;

ๆ: eficiência estimada de um motor de ciclo combinado;

$\sigma^{2}$ : Variância da curva E (t) normalizada;

$\overline{\theta h}$ : Tempo de residência médio;

$\sigma_{\Theta}^{2}$ : Variância adimensional da curva $\mathrm{E}(\mathrm{t})$. 


\section{SUMÁRIO}

1. INTRODUÇÃO

2. OBJETIVOS

2.1 Objetivo Geral 31

2.2 Objetivos Específicos 31

2.2.1 OBJETIVO ESPECÍFICO 1 31

2.2.2 OBJETIVO ESPECÍFICO 2 32

2.2.3 OBJETIVO ESPECÍFICO 3 33

3. REVISÃO BIBLIOGRÁFICA 34

3.1 DRenagens Ácidas de Minas (DAM) 34

3.2 TRATAMENTO das DAM 37

3.3 DOADORES DE ELÉTRONS PARA A REDUÇÃo BIOLÓGICA DE SULFATO 40

3.4 RELAÇõES DQO/SULFATO APLICADAS AO TRATAMENTO DAS DAM 43

3.5 Microbiologia das bactérias REDUtORAS de SUlFato 45

3.6 CONFIGURAÇõES DE REATORES APLICADOS À RECUPERAÇÃO DE METAIS 48

3.7 CONTRIBUIÇÃO DO ÍON BISSULFETO NA ALCALINIDADE DE REATORES ANAERÓBIOS 52

4. MATERIAL E MÉTODOS 57

4.1 Delineamento experimental 57

4.1.1 ETAPA 1 - REFERENTE AO OBJETIVO ESPECÍFICO 1 60

4.1.2 ETAPA 2 - REFERENTE AO OBJETIVO ESPECÍFICO 2 61

4.1.3 ETAPA 3-REFERENTE AO OBJETIVO ESPECÍFICO 3 62

4.2 REATOR DFSBR 63

4.3 MATERIAL SUPORTE E ZONA DE SEDIMENTAÇão 64

4.4 INOCULAÇÃO 68

4.5 Água RESIDUÁRIA 69

4.5.1 ÁGUA RESIDUÁRIA SINTÉTICA (ETAPA 1) 69

4.5.2 VINHAÇA DE CANA-DE-AÇÚCAR (ETAPAS 2 E 3) 73

4.6 ANÁLISES FÍSICO-QUÍMICAS 75 
4.6.1 $\mathrm{PH} \longrightarrow 76$

4.6.2 DEMANDA QUÍMICA DE OXIGÊNIO (DQO) E SULFETO TOTAL DISSOLVIDO (STD)___ 76

4.6.3 SUlfeTO TOTAL NO EFLUENTE (STE)__ 79

4.6.4 SULFATO DISSOLVIDO__ 79

4.6.5 FERRO TOTAL _ 80

4.6.6 COMPOSIÇÃO ELEMENTAR DO PRECIPITADO___ 81

4.6.7 COMPOSIÇÃO DOS ÁCIDOS ORGÂNICOS VOLÁTEIS ___ 82

4.6.8 COMPOSIÇÃO DO BIOGÁS ___ 83

4.7 AVALIAÇÃo da ALCALINIDADE DEVIDA A SULFETo ___ 83

$\begin{array}{llr}4.8 & \text { ENSAIOS HIDRODINÂMICOS } & 88\end{array}$

4.9 AVALIAÇÃo da CINÉtICA DE REMOÇão de MATÉRIA ORGÂNICA E SULFATO NO DFSBR ___ 91

4.10 MiCROSCOPIA ÓPTICA _ 93

4.11 ANÁLISE DA DIVERSIDADE MICROBIANA (PCR/DGGE) _ _ 93

4.12 CARACTERIZAÇÃo MicrobianA POR SEQUENCIAMENTO do RNAR 16S 95

4.13 Parâmetros Calculados

4.13.1 VIAS DE REMOÇÃO DA MATÉRIA ORGÂNICA __ 96

4.13.2 ESTIMATIVA DO METANO DISSOLVIDO___ 98

4.13.3 ESPECIAÇÃO DO SULFETO TOTAL DISSOLVIDO _ 99

4.13.4 EFICIÊNCIA DE REMOÇÃO DE FERRO __ 101

4.13.5 ESTIMATIVA DO POTENCIAL DE PRODUÇÃO DE ENERGIA A PARTIR DO BIOGÁS NO DFSBR___ 101

4.14 ANÁLISES Estatísticas ___ 103

5. RESULTADOS E DISCUSSÃO

5.1 ETAPA 1: DESEMPENHO GERAL DO DFSBR __ 105

5.1.1 REMOÇÃO DE MATÉRIA ORGÂNICA E SULFATO __ 105

5.1.2 PRODUÇÃO de SULFETO E PRECIPITAÇÃO dE FERRO _ 115

5.1.3 PRODUÇÃO dE METANO _ 126

5.1.4 CARACTERIZAÇÃO DA DIVERSIDADE MICROBIANA-ETAPA 1 _ 127

5.1.5 CONSIDERAÇÕES FINAIS RELATIVAS À ETAPA 1

5.2 ETAPA 1: AVALIAÇÃo dA ALCALINIDADE DEVIDA A SULFETO____ 134

5.2.1 AVALIAÇÃO DA CONTRIBUIÇÃO DO ÍON BISSULFETO (HS) PARA A ALCALINIDADE TOTAL DO MEIO LÍQUIDO_ 134

5.2.2 ALCALINIDADE DEVIDA A SULFETO NO DFSBR _ _ 142

5.2.3 CONSIDERAÇÕES FINAIS RELATIVAS À ALCALINIDADE DEVIDA A SULFETO __ 145 
5.3 ETAPA 2: INFLUÊNCIA DA RECIRCULAÇÃO NO DFSBR 147

5.3.1 CARACTERIZAÇÃO HIDRODINÂMICA DO DFSBR SOB DIFERENTES RAZÕES DE RECICLO 147

5.3.2 DESEMPENHO DO DFSBR SOB DIFERENTES RAZÕES DE RECIRCULAÇÃO 154

5.3.3 BALANÇOS DE MATÉRIA ORGÂNICA E ENXOFRE 166

5.3.4 PRECIPITAÇÃO dE SULFETOS DE FERRO EM DIFERENTES RAZÕES DE RECICLO_ 171

5.3.5 PERFIS ESPACIAIS DO DFSBR SOB DIFERENTES RAZÕES DE RECICLO 177

5.3.6 CARACTERIZAÇÃO DA DIVERSIDADE MICROBIANA - ETAPA 2 179

5.3.7 ENSAIOS CINÉTICOS A PARTIR DE DIFERENTES DOADORES DE ELÉTRONS 183

5.3.8 CONSIDERAÇÕES FINAIS RELATIVAS À ETAPA 2 190

5.4 ETAPA 3: INFLUÊNCIA DO PH AFLUENTE SOBRE O DESEMPENHO DO DFSBR 193

5.4.1 DESEMPENHO DO DFSBR SUBMETIDO À DIMINUIÇÃO DO PH AFLUENTE 193

5.4.2 EFEITO DO PH INTERNO SOB AS ESPÉCIES DE SULFETO DISSOLVIDO NO DFSBR 207

5.4.3 INFLUÊNCIA DO ABAIXAMENTO DO PH SOBRE A PRECIPITAÇÃO DE SULFETOS DE FERRO NO DFSBR 209

5.4.4 CARACTERIZAÇÃO DA DIVERSIDADE MICROBIANA - ETAPA 3 213

5.4.5 CARACTERIZAÇÃO DA COMUNIDADE MICROBIANA POR SEQUENCIAMENTO DO RNAR 16S 217

5.4.6 EStIMATIVA DO POTENCIAL ENERGÉtICO DO DFSBR TRATANDO DAM EM CO-DIGESTÃO COM VINHAÇA DE CANA-DE-AÇÚCAR 227

5.4.7 CONSIDERAÇÕES FINAIS RELATIVAS À ETAPA 3 229

6. CONCLUSÕES 232

7. SUGESTÕES PARA TRABALHOS FUTUROS 235

8. REFERÊNCIAS BIBLIOGRÁFICAS 237 



\section{INTRODUÇÃO}

Diversos setores industriais, especialmente a atividade mineradora, são responsáveis pela geração de águas residuárias caracterizadas por baixos valores de $\mathrm{pH}$ e altas concentrações do íon sulfato e metais dissolvidos, principalmente metais pesados (JOHNSON; HALLBERG, 2005). A liberação no ambiente dessas águas residuárias, comumente chamadas de drenagens ácidas de minas (DAM), pode comprometer em longo prazo a qualidade dos corpos d'água e do solo, a vida aquática e também a saúde dos seres humanos (CHEN et al., 2014; AKCIL; KOLDAS, 2006).

Entre os diversos tratamentos propostos para as DAM têm-se os métodos físicoquímicos convencionais, baseados na adição de compostos alcalinos para a precipitação dos metais pesados sob a forma de hidróxidos (JOHNSON; HALLBERG, 2005). Estas estratégias de tratamento, além dos altos custos associados à dosagem de produtos químicos aos grandes volumes de drenagens ácidas, também levam à geração de resíduos sólidos de difícil disposição (GARCÍA et al., 2001).

Uma alternativa para o tratamento das DAM é a aplicação de processos biológicos baseados na redução do sulfato em condições anaeróbias. Entre os benefícios proporcionados por esse processo estão a produção de alcalinidade, a precipitação dos metais sob a forma de sulfetos insolúveis e a geração de menores quantidades de lodo, o qual pode ser disposto com baixos custos (RODRIGUEZ, 2010; GALLEGOS-GARCIA et al., 2009).

Diante do crescimento da demanda por metais, o que tem levado à escassez dos recursos minerais e ao aumento dos custos associados à sua obtenção, a recuperação de metais a partir de águas residuárias, como as DAM, também tem se tornando uma alternativa atrativa do ponto de vista econômico e ambiental (VILLA-GOMEZ et al., 2011).

A precipitação dos metais presentes em águas residuárias ricas em sulfato pode ser obtida em sistemas biológicos sob condições anaeróbias, as quais possibilitam o metabolismo 
das bactérias redutoras de sulfato (BRS), que utilizam o íon sulfato (presente nas DAM em altas concentrações) como aceptor final de elétrons na oxidação do hidrogênio ou da matéria orgânica, produzindo bicarbonato e sulfeto de hidrogênio (LENS et al., 1998). O sulfeto, por sua vez, reage com alguns metais dissolvidos, precipitando-os sob a forma de sulfetos metálicos insolúveis (HAO, 2003), passíveis de separação da fase líquida com a aplicação de estratégias adequadas.

A reduzida concentração de matéria orgânica presente nas drenagens ácidas, porém, exige a adição de uma fonte de carbono externa que possibilite a atuação dos microrganismos envolvidos na redução biológica do sulfato. Entre os diversos substratos orgânicos já estudados tem-se o metanol (TSUKAMOTO; MILLER, 1999), o etanol (RODRIGUEZ et al., 2012; TSUKAMOTO et al., 2004; KAKONSEN et al., 2003), o butanol (SARTI; ZAIAT, 2011), o lactato (RODRIGUEZ; ZAIAT, 2011; ELLIOT et al., 1998), o propionato (GREBEN et al., 2004), entre outros.

Visando minimizar os custos associados à adição desses substratos orgânicos comerciais, tem se investigado também a viabilidade do uso de resíduos orgânicos como doadores de elétrons para o tratamento das DAM (ZAGURY et al., 2006; WAYBRANT et al., 1998). Pela produção de vinhaça de cana-de-açúcar em larga escala no Brasil (MORAES et al., 2015), essa água residuária, proveniente da indústria sucroalcooleira, representa um doador de elétrons em potencial para o tratamento biológico de DAM, principalmente devido ao seu elevado conteúdo de matéria orgânica (PARNAUDEAU et al., 2008; WILKIE et al., 2000), tendo sido escolhido para a realização do presente estudo.

Além de diferentes doadores de elétrons para o metabolismo das BRS, diversas configurações de reatores também têm sido estudadas para os processos combinados de redução de sulfato e precipitação de metais (KAKSONEN; PUHAKKA, 2007). Entretanto, nem sempre o processo se dá de forma satisfatória, uma vez que os metais precipitados podem 
permanecer retidos no material suporte, no grânulo ou biofilme, dificultando a sua recuperação (VILLA-GOMEZ et al., 2011). Algumas alternativas propostas consistem na utilização de reatores em série, os quais possibilitam a ocorrência da redução biológica do sulfato e da precipitação dos sulfetos metálicos em estágios separados (XINGYU et al., 2013; UCAR et al., 2011).

Outra configuração recentemente apresentada é a do reator de leito fluidizado inverso (reator fluidizado de fluxo descendente), o qual consiste na fluidização de um material suporte de densidade inferior à do meio líquido, ou seja, que se mantenha na parte superior da coluna do reator. O sistema promove a precipitação dos sulfetos metálicos e possibilita a sua recuperação na parte inferior do reator, a qual permanece livre de biomassa (VILLA-GOMEZ et al., 2011; GALLEGOS-GARCIA et al., 2009). A vantagem dessa configuração está relacionada com a remoção eficiente de matéria orgânica e sulfato, a elevação do pH devido à sulfetogênese e a recuperação de metais precipitados como sulfetos insolúveis em um mesmo reator (SAHINKAYA; GUNGOR, 2010). Todavia, reatores de leito fluidizado exigem maiores gastos energéticos para a manutenção da fluidização do leito, a qual é obtida por meio da aplicação de altas vazões de recirculação.

Como alternativa, propôs-se no presente estudo a utilização do reator anaeróbio de leito fixo-estruturado (AFSBR) (MOCKAITIS, 2011), uma vez que essa configuração possibilita uma alta retenção de biomassa no material suporte associada à manutenção de uma área de escoamento livre na seção transversal do leito. Nesse caso, a espessura do biofilme é regulada pelas forças de cisalhamento proporcionadas pelas velocidades superficiais do escoamento (MOCKAITIS et al., 2014). A aplicação do fluxo descendente e a manutenção de uma câmara livre de material suporte na base do reator, por sua vez, são modificações originalmente propostas para viabilizar o controle operacional do acúmulo de biomassa em sistemas aplicados à produção de bio-hidrogênio (ANZOLA-ROJAS et al., 2016; ANZOLA- 
ROJAS; ZAIAT, 2015). Essas estratégias também foram adotadas para avaliação do seu potencial em favorecer a formação e precipitação de sulfetos metálicos insolúveis, proporcionando um arraste mais efetivo do material precipitado, contornando o problema de deposição dos metais sobre o biofilme e facilitando a sua recuperação na zona de sedimentação do reator. 


\section{OBJETIVOS}

\subsection{Objetivo Geral}

O objetivo geral do presente estudo foi avaliar o potencial de uma configuração inovadora, o reator anaeróbio de leito fixo-estruturado e fluxo descendente (down-flow fixedstructured bed reactor - DFSBR), aplicado ao tratamento de DAM em co-digestão com vinhaça concentrada de cana-de-açúcar.

Tal objetivo geral foi sustentado pela seguinte hipótese central: A utilização do DFSBR promoverá a melhoria dos balanços energético e econômico do tratamento de DAM pela eliminação da dosagem de substratos orgânicos comerciais, substituídos por uma água residuária complexa (vinhaça), com potencial para a recuperação de metais de interesse para a atividade industrial e pelo reaproveitamento do biogás rico em metano gerado.

\subsection{Objetivos Específicos}

O objetivo geral do presente estudo foi desdobrado em alguns objetivos específicos, fundamentados em suas respectivas sub-hipóteses, abaixo elencadas:

\subsubsection{Objetivo específico 1}

Avaliar o potencial do reator de leito fixo-estruturado e fluxo descendente (DFSBR) no tratamento de uma água residuária sintética simulando a mistura de DAM com vinhaça em relação $\mathrm{DQO} /$ sulfato $=2,0$ e submetido ao aumento da concentração de ferro na DAM afluente visando à precipitação e remoção de sulfetos metálicos. 
Sub-hipótese 1A: A relação DQO/sulfato maior que a estequiométrica (>0,67) permitirá o estabelecimento dos processos metanogênico e sulfetogênico associados, levando à estabilidade do processo anaeróbio com eficiente remoção de matéria orgânica e sulfato;

Sub-hipótese 1B: A configuração do leito fixo-estruturado e o fluxo descendente proporcionará a formação e a precipitação de sulfetos metálicos no DFSBR, bem como a sua separação efetiva na câmara inferior do reator;

Sub-hipótese 1C: O sulfeto dissolvido, devido às propriedades da sua especiação química, contribui expressivamente com a capacidade tampão de reatores sulfetogênicos, de forma que a sua diminuição gradual, induzida pelo aumento na carga de ferro aplicada, será uma das principais causas da perda de alcalinidade do sistema.

\subsubsection{Objetivo específico 2}

Avaliar a influência de diferentes razões de recirculação (e suas velocidades superficiais de escoamento) sobre o regime hidrodinâmico do reator DFSBR e sobre o desempenho do sistema no tratamento conjunto de DAM e vinhaça real, visando ao estabelecimento de melhores condições para a formação e sedimentação de sulfetos metálicos.

Sub-hipótese 2A: Maiores razões de recirculação proporcionarão condições mais efetivas de arraste dos sulfetos metálicos formados no reator, evitando sua deposição sobre o biofilme e possibilitando uma recuperação mais significativa dos mesmos;

$\checkmark \quad$ Sub-hipótese 2B: Excessivas velocidades superficiais de escoamento poderão afetar negativamente a estabilidade do processo biológico, promovendo o desprendimento do biofilme, com prejuízo para o processo biológico; 
$\checkmark \quad$ Sub-hipótese 2C: A vinhaça é uma água residuária com conteúdo orgânico e mineral passível de ser utilizada como doador de elétrons, fonte exclusiva de carbono e nutrientes para o tratamento biológico de uma DAM, possibilitando o estabelecimento de uma biomassa versátil, com a associação de processos sulfetogênicos e metanogênicos no sistema.

\subsubsection{Objetivo específico 3}

Avaliar o desempenho geral do DFSBR e as modificações da comunidade microbiana quando submetido à diminuição gradual do pH afluente, pela redução na dosagem de agente alcalinizante.

$\checkmark \quad$ Sub-hipótese 3A: A sulfetogênese estabelecida a partir da vinhaça de cana-deaçúcar possibilitará a neutralização de uma DAM sintética sem adição externa de álcali graças à geração de alcalinidade associada à redução de sulfato, provendo maior robustez ao processo;

$\checkmark \quad$ Sub-hipótese 3B: A diminuição do pH afluente do DFSBR durante o tratamento de uma DAM sintética permitirá investigar a influência desse parâmetro sobre a precipitação de sulfetos metálicos no reator;

Sub-hipótese 3C: A supressão na dosagem de álcali externo implicará na acidificação do meio líquido, com modificação das populações microbianas presentes no sistema, e promoverá a restrição do metabolismo metanogênico, antes favorecido pelas condições aplicadas ao início da operação do reator. 


\section{REVISÃO BIBLIOGRÁFICA}

\subsection{Drenagens ácidas de minas (DAM)}

Entre os problemas ambientais mais graves causados pela atividade mineradora está a liberação das drenagens ácidas de minas (DAM), uma água residuária largamente produzida em minas a céu aberto e subterrâneas, em bacias de rejeitos da mineração e em pilhas de estocagem de minérios contendo sulfetos (NASCIMENTO, 1998).

Os sulfetos minerais, tais como a pirita e a marcassita (polimorfos de fórmula $\mathrm{FeS}_{2}$ ), uma vez em contato com a água e com o oxigênio atmosférico, são espontaneamente oxidados (Equação (3.1)) levando à produção de ácido sulfúrico e promovendo a solubilização dos metais pesados presentes em solos e rochas (AKCIL; KOLDAS, 2006).

$$
\mathrm{FeS}_{2}+7 / 2 \mathrm{O}_{2}+\mathrm{H}_{2} \mathrm{O} \rightarrow \mathrm{Fe}^{2+}+2 \mathrm{SO}_{4}{ }^{2-}+2 \mathrm{H}^{+}
$$

Desta forma, as DAM são caracterizadas por altas concentrações de sulfato, as quais chegam a ultrapassar $2000 \mathrm{mg} . \mathrm{L}^{-1}$, acidez pronunciada e elevado conteúdo de metais, tais como ferro, cobre, zinco, alumínio, chumbo e cádmio (MELLO et al., 2014; UCAR et al., 2011). A Tabela 3.1 apresenta a composição média de algumas DAM encontradas no Brasil. 
Tabela 3.1: Composições de DAM provenientes de minerações localizadas em alguns municípios brasileiros.

\begin{tabular}{|c|c|c|c|c|c|}
\hline & $\begin{array}{l}\text { Forquilhinha } \\
\text { (SC) }\end{array}$ & $\begin{array}{l}\begin{array}{l}\text { Urussanga } \\
\text { (SC) }{ }^{(2)}\end{array} \\
\end{array}$ & $\begin{array}{l}\text { Lauro Muller } \\
\text { (SC) }\end{array}$ & $\begin{array}{l}\text { Poços de Caldas } \\
\text { (MG) }^{(4)}\end{array}$ & $\begin{array}{l}\text { Charqueada } \\
\text { (RS) })^{(5)}\end{array}$ \\
\hline pH & 2,3 & 2,8 & 2,7 & 3,5 & 2,7 \\
\hline DQO (mg.L $\left.L^{-1}\right)$ & - & 34 & - & - & 43 \\
\hline DBO $\left(\mathrm{mg.L}^{-1}\right)$ & - & 7,0 & - & - & 5,0 \\
\hline NTK (mg.L L $\left.^{-1}\right)$ & - & 2,36 & - & - & 4,0 \\
\hline Fósforo $\left(\mathbf{m g . L} \mathbf{L}^{-1}\right)$ & - & 0,255 & - & $<0,03$ & 0,03 \\
\hline Sulfato $\left(\mathrm{mg} . \mathrm{L}^{-1}\right)$ & 9120 & 1699 & 383 & 1550 & 989 \\
\hline Ferro $\left(\right.$ mg.L $\left.^{-1}\right)$ & 5900 & 112 & 2460 & - & 208 \\
\hline Alumínio (mg.L $\left.\mathrm{L}^{-1}\right)$ & 2000 & 134 & 1295 & - & 19 \\
\hline Manganês (mg.L ${ }^{-1}$ ) & 129 & 7 & 120 & 138 & 9 \\
\hline Cobre (mg.L $\left.{ }^{-1}\right)$ & 0,07 & - & $<0,10$ & - & 0,03 \\
\hline $\operatorname{Zinco}\left(\mathbf{m g . L}^{-1}\right)$ & 65 & 1,5 & 19 & 22,6 & 0,1 \\
\hline Níquel (mg.L $\left.{ }^{-1}\right)$ & - & - & - & - & ND* \\
\hline Cádmio (mg.L $\left.{ }^{-1}\right)$ & 0,06 & - & $<0,10$ & - & ND* \\
\hline Cromo (mg.L $\left.L^{-1}\right)$ & 0,24 & - & 0,30 & - & ND* \\
\hline Chumbo (mg.L $\left.{ }^{-1}\right)$ & $<0,03$ & - & 1,20 & _- & ND* \\
\hline
\end{tabular}

*ND: Não detectado.

Fonte: ${ }^{(1)}$ MENEZES, 2009; (2) NUNES, 2010; ${ }^{(3)}$ SULZBACH, 2015; ${ }^{(4)}$ BENEDETTO, 2005; ${ }^{(5)}$ KONARZEWKI; SCHNEIDER, 2009.

Embora os bissulfetos de ferro sejam encontrados predominantemente associados com a exploração de carvão, níquel, chumbo, zinco, cobre, urânio, ouro e prata, a ocorrência de DAM também pode ser ocasionada por grandes obras de engenharia que exijam alta movimentação ou escavação de terra e rochas contendo minerais sulfetados, tais como para a construção de estradas, túneis, barragens e aeroportos (MELLO et al., 2014).

Após o processo inicial de oxidação da pirita $\left(\mathrm{FeS}_{2}\right)$ levando à solubilização do íon ferroso em meio ácido, se o potencial de oxidação for mantido, diversas outras reações ocorrerão conforme as equações (3.2) e (3.3) abaixo apresentadas (AKCIL; KOLDAS, 2006). 


$$
\begin{aligned}
& \mathrm{Fe}^{2+}+1 / 4 \mathrm{O}_{2}+\mathrm{H}^{+} \rightarrow \mathrm{Fe}^{3+}+1 / 2 \mathrm{H}_{2} \mathrm{O} \\
& \mathrm{Fe}^{3+}+3 \mathrm{H}_{2} \mathrm{O} \rightarrow \mathrm{Fe}(\mathrm{OH})_{3(\mathrm{~s})}+3 \mathrm{H}^{+}
\end{aligned}
$$

Embora a reação (3.2) ocorra lentamente em condições abióticas, alguns microrganismos acidófilos, especialmente aqueles pertencentes ao gênero Acidithiobacilus, podem atuar como catalisadores biológicos, favorecendo a oxidação do íon ferroso $\left(\mathrm{Fe}^{2+}\right)$ a íon férrico $\left(\mathrm{Fe}^{3+}\right)$ (GLEISNER et al., 2006). Em ambiente ácido $(\mathrm{pH}<3,0)$ a reação $(3.3)$ será deslocada no sentido da geração de produtos, levando a uma maior concentração de $\mathrm{Fe}^{3+}$ em solução, o qual passará a atuar como principal agente oxidante do mineral sulfetado (Equação (3.4)). Devido a esse efeito auto-propagante de oxidação da pirita disponível pelo íon férrico, e sob as baixas concentrações de oxigênio dissolvido nas DAM, o ferro em solução se encontrará predominantemente em sua forma iônica bivalente $\left(\mathrm{Fe}^{2+}\right)(\mathrm{AKCIL} ; \mathrm{KOLDAS}$, 2006).

$\mathrm{FeS}+14 \mathrm{Fe}^{3+}+8 \mathrm{H}_{2} \mathrm{O} \rightarrow 15 \mathrm{Fe}^{2+}+2 \mathrm{SO}_{4}{ }^{2-}+16 \mathrm{H}^{+}$

Os impactos adversos das drenagens ácidas são extensos e duradouros, uma vez que as áreas exploradas são expressivamente grandes e a geração das DAM não cessa com o encerramento das atividades mineradoras. Dessa forma, as áreas mineradas permanecem contribuindo com a poluição do solo e dos corpos hídricos indefinidamente (JOHNSON; HALLBERG, 2005).

O baixo valor de $\mathrm{pH}$ das DAM, o qual pode chegar a menos de 3,50, e a alta concentração de metais tóxicos e sulfatos prejudicam os ecossistemas aquáticos, levando à diminuição da riqueza e diversidade da biota (GRAY, 1997), bem como impedindo a 
utilização dos corpos d'água contaminados como fonte de abastecimento para o consumo humano (CHEN et al., 2014; MELLO et al., 2014). A contaminação de peixes e outros seres aquáticos, os quais são consumidos por organismos superiores, inclusive seres humanos, também pode resultar em efeitos deletérios para a saúde devido aos efeitos bioacumulativos dos metais pesados e outros metaloides ao longo da cadeia alimentar, especialmente em função de suas propriedades cancerígenas, teratogênicas, neuro e nefrotóxicas (FADIRAN et al., 2014).

\subsection{Tratamento das DAM}

Dentre os métodos mais utilizados para o tratamento das DAM tem-se a neutralização química e a precipitação de hidróxidos metálicos por meio da adição de agentes alcalinizantes (AKCIL; KOLDAS, 2006; JOHNSON; HALLBERG, 2005). Todavia, em função dos grandes volumes de drenagens ácidas, os gastos com a adição de reagentes químicos, bem como a produção de resíduos de difícil disposição ao fim do tratamento, são limitações inerentes a tais processos (KAKSONEM; PUHAKKA, 2007; GARCÍA et al., 2001).

Outros métodos de tratamento aplicados a essas águas residuárias consistem em osmose reversa, resinas de troca iônica, processos de adsorção (em zeólitas, gel de sílica, alumínio ou carvão ativado), entre outros (MOTSI, 2010). Todavia, os altos custos de implantação e os grandes volumes de DAM geradas inviabilizam o recurso a essas tecnologias em larga escala.

Uma alternativa que tem sido apontada como viável nas últimas décadas para o tratamento das drenagens ácidas de minas é a aplicação do processo biológico anaeróbio. As altas concentrações de sulfato presente nas DAM possibilitam o metabolismo das bactérias redutoras de sulfato (BRS), que utilizam o íon $\mathrm{SO}_{4}{ }^{2-}$, presente nas DAM, como aceptor final de elétrons na oxidação da matéria orgânica ou hidrogênio. Os produtos dessa reação são 
sulfeto de hidrogênio $\left(\mathrm{H}_{2} \mathrm{~S}\right)$ e alcalinidade $\left(\mathrm{HCO}_{3}^{-}\right)$, ambos importantes para o incremento do pH do meio líquido (Equação (3.5)) (GODOI et al., 2017b; UCAR et al., 2011; GALLEGOSGARCIA et al., 2009).

$2 \mathrm{CH}_{2} \mathrm{O}+\mathrm{SO}_{4}{ }^{2-} \rightarrow \mathrm{H}_{2} \mathrm{~S}+2 \mathrm{HCO}_{3}^{-}$

$\mathrm{Na}$ qual $\mathrm{CH}_{2} \mathrm{O}$ representa genericamente uma molécula doadora de elétrons.

O sulfeto biogênico (gerado biologicamente pelas BRS), o qual apresenta características tóxicas e corrosivas e odor desagradável, por sua vez, reage com os metais em solução (Equação (3.6)) formando sulfetos metálicos insolúveis, que precipitam e podem ser posteriormente separados da fase líquida e submetidos a processos físico-químicos para recuperação dos metais de interesse (SAHINKAYA; GUNGOR, 2010).

$\mathrm{H}_{2} \mathrm{~S}+\mathrm{Me}^{2+} \leftrightharpoons \mathrm{MeS}_{(\mathrm{s})}+2 \mathrm{H}^{+}$

$\mathrm{Na}$ qual $\mathrm{Me}^{2+}$ representa genericamente um cátion metálico bivalente, passível de ser precipitado, tais como $\mathrm{Ag}^{2+}, \mathrm{Cd}^{2+}, \mathrm{Co}^{2+}, \mathrm{Cu}^{2+}, \mathrm{Fe}^{2+}, \mathrm{Hg}^{2+}, \mathrm{Ni}^{2+}, \mathrm{Pb}^{2+}, \mathrm{Zn}^{2+}$, entre outros.

A geração de alcalinidade promovida pelos processos biológicos de redução de sulfato é também um fator importante tanto para a adequação ambiental das drenagens ácidas, quanto para os processos de precipitação dos metais em solução. De fato, a maioria dos metais apresenta baixos valores de solubilidade em faixas de $\mathrm{pH}$ acima da neutralidade $(\mathrm{pH}>7,0)$, sendo facilmente separados da fase líquida por precipitação, seja pela formação de sulfetos metálicos insolúveis (Figura 3.1) ou hidróxidos (Figura 3.2) (LEWIS, 2010). 


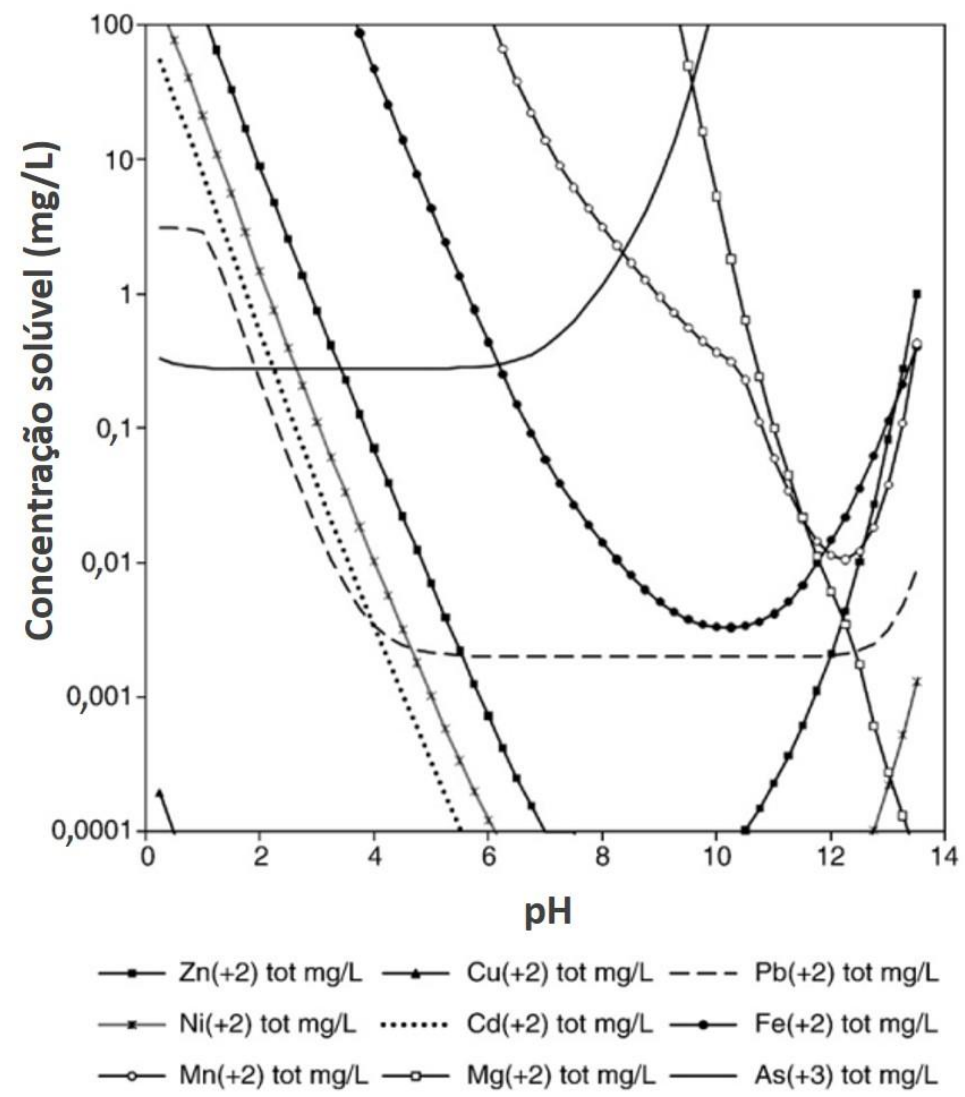

Figura 3.1: Solubilidade de diversos sulfetos metálicos em função do pH.

Fonte: LEWIS, 2010.

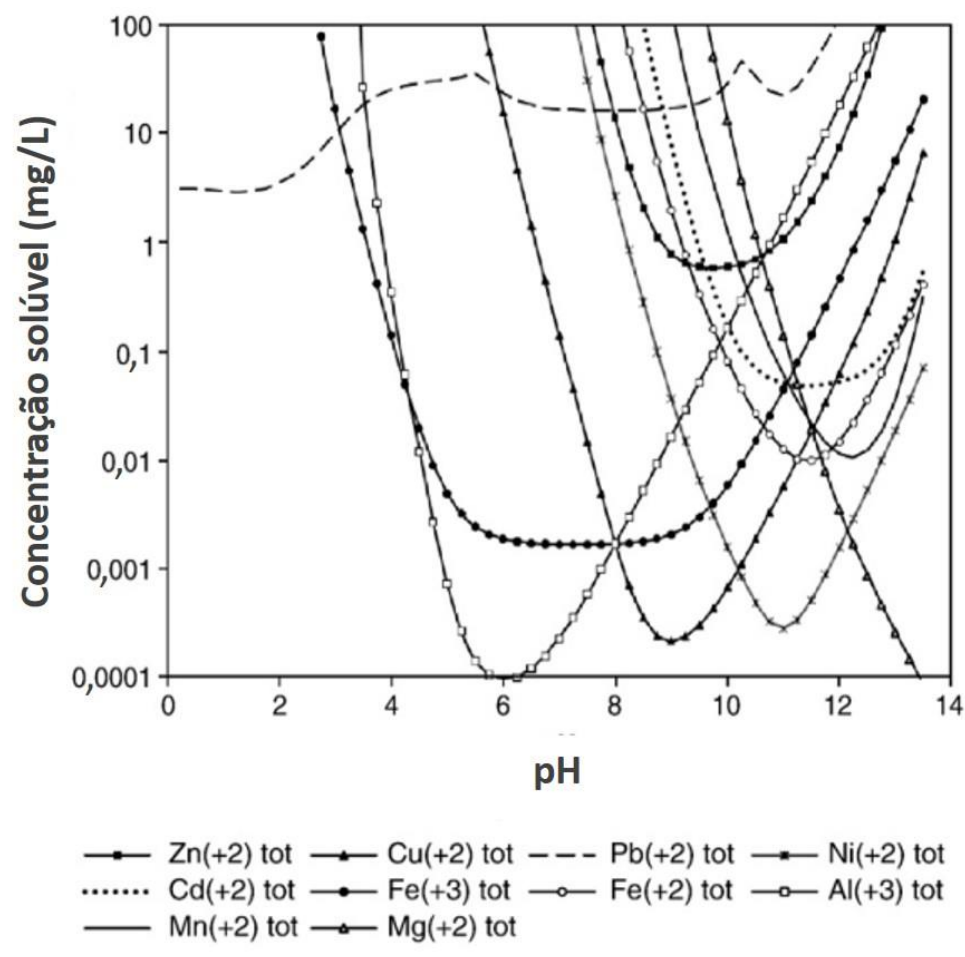

Figura 3.2: Solubilidade de hidróxidos metálicos em função do pH.

Fonte: LEWIS, 2010. 
As vantagens do processo biológico baseado na redução de sulfato para a precipitação de metais devem-se também ao fato dos sulfetos metálicos apresentarem melhores propriedades de precipitação, rápidas taxas de reação, menor solubilidade do precipitado, além de um maior potencial de reaproveitamento de metais sulfetados por processos de combustão/fundição (LEWIS, 2010).

Uma vez que os produtos de solubilidade (Kps) de diversos sulfetos metálicos são menores que os Kps dos respectivos hidróxidos metálicos, menores concentrações residuais desses complexos na fase líquida também são mais facilmente alcançadas, possibilitando a obtenção de maiores eficiências de remoção de metais em sistemas biológicos de tratamento de DAM baseados na precipitação com sulfeto (LEWIS, 2010; JOHNSON et al., 2006).

\subsection{Doadores de elétrons para a redução biológica de sulfato}

Em função de seu conteúdo desprezível de matéria orgânica, o tratamento biológico das drenagens ácidas requer a introdução de doadores de elétrons externos, passíveis de serem utilizados pelas BRS nos processos de redução de sulfato, o qual atua como aceptor final de elétrons (LENS et al., 1998). A escolha do doador de elétrons deverá levar em consideração a sua disponibilidade, facilidade no manuseio, os custos com aquisição e o potencial de utilização pelas BRS (KAKSONEM; PUHAKKA, 2007).

Os doadores de elétrons que podem ser oxidados pelas bactérias redutoras de sulfato consistem, geralmente, em compostos orgânicos de baixo peso molecular, tais como ácidos orgânicos (lactato, propionato, butirato, piruvato) e álcoois (principalmente o etanol) (LIAMLEAM; ANNACHHATRE, 2007; HAO, 2003).

De fato, para o tratamento anaeróbio das DAM, as fontes de carbono comumente utilizadas consistem, em sua maioria, de substratos orgânicos comerciais, de considerável valor econômico, tais como o metanol (TSUKAMOTO; MILLER, 1999), o etanol 
(RODRIGUEZ et al., 2012; SARTI et al., 2009; TSUKAMOTO et al., 2004; KAKONSEN et al., 2003), o lactato (RODRIGUEZ; ZAIAT, 2011; ELLIOT et al., 1998), ácidos orgânicos voláteis (CELIS-GARCIA et al., 2007; GREBEN et al., 2004) e sacarose (GREBEN et al., 2000).

A busca por substratos mais adequados e com menores custos associados tem levado ao estudo da utilização de águas residuárias orgânicas que sejam passíveis de tratamento pela via anaeróbia (ZAGURY et al., 2006). A mistura de vários doadores de elétrons presentes nesses resíduos pode proporcionar taxas de redução de sulfato maiores que as obtidas com o uso de um único tipo de substrato orgânico graças à disponibilização de carbono em suas diversas formas (LIAMLEAM; ANNACHHATRE, 2007; WAYBRANT et al., 1998).

A vinhaça de cana-de-açúcar, subproduto líquido resultante da produção de etanol a partir da fermentação do caldo da cana-de-açúcar, é uma água residuária largamente produzida no Brasil e passível de ser submetida ao tratamento anaeróbio (MORAES et al., 2015; WILKIE et al., 2000). Entre os componentes orgânicos da vinhaça podem ser citados diversos ácidos orgânicos (acético, lático, propiônico, butírico), concentrações residuais de carboidratos (sacarose), álcoois (etanol, metanol, glicerol), além de compostos aromáticos (PARNAUDEAU et al., 2008; WILKIE et al., 2000).

Vinhaças ricas em sulfato já têm sido apresentadas na literatura como substratos adequados para o estabelecimento da sulfetogênese (BARRERA et al., 2014; BARRERA et al., 2013), muito embora a sua aplicação como doador de elétrons no tratamento de uma drenagem ácida sintética só tenha sido testada por um único trabalho encontrado na literatura (GONÇALVES et al., 2007). Assim, a vinhaça de cana-de-açúcar representaria um doador de elétrons com potencial para ser testado em maior profundidade no tratamento biológico de DAM, visando-se a produção de sulfeto para a remoção de metais. 
Outra vantagem do tratamento em conjunto das DAM com a vinhaça de cana-deaçúcar poderia estar ligada ao fato de, pela diluição da fração orgânica da vinhaça ao ser misturada com as drenagens ácidas, obter-se um efluente com menores teores de matéria orgânica, com o favorecimento do processo anaeróbio. Também a diluição da DAM após a adição da vinhaça resultará em um efluente final com menores concentrações de sulfato, evitando a produção de sulfeto em excesso, o qual pode vir a ser tóxico aos microrganismos envolvidos no processo anaeróbio (MAILLACHERUVU et al., 1993; HILTON; OLESZKIEWICZ, 1988).

Um fator limitante para a aplicação da vinhaça ao tratamento de DAM se deve às grandes distâncias entre as unidades geradoras de vinhaça e as instalações da atividade mineradora, exigindo o transporte de altos volumes de substrato orgânico. Por outro lado, algumas usinas tem implantado o processo de concentração da vinhaça restante da destilação do etanol (MUTTON et al., 2014). A concentração da vinhaça por evaporação, por exemplo, possibilita a recuperação da sua fração orgânica, a qual pode ser então utilizada como ração animal, como combustível para caldeiras, ou mesmo para aplicação como fertilizante, diminuindo os volumes transportados (MUTTON et al., 2014). O vapor recuperado da vinhaça após o seu processo de concentração pode ser condensada e retornar como água de reuso industrial (MUTTON et al., 2014). Entre diversos métodos de concentração da vinhaça também se encontra a floculação seguida de sedimentação e filtração (NICOLAIEWSKY, 1981), a bioconcentração, por reaproveitamento da vinhaça no caldo de fermentação (NAVARRO et al., 2000), a nanofiltração acoplada à osmose reversa (NATARAJ et al., 2006) e a microfiltração por membranas (GOMES et al., 2011).

A vinhaça concentrada, isto é, com uma concentração orgânica e mineral acima da vinhaça in natura, passa a se tornar mais atrativa para utilização como doador de elétrons em sistemas de tratamento de DAM. Todavia, o alto custo energético da vinhaça, 
independentemente do processo escolhido, é ainda sua principal restrição para sua aplicação generalizada (MUTTON et al., 2014).

\subsection{Relações DQO/sulfato aplicadas ao tratamento das DAM}

Um dos parâmetros a ser levado em conta quando se deseja o estabelecimento dos processos sulfetogênicos em sistemas de tratamento anaeróbios é a relação $\mathrm{DQO} / \mathrm{SO}_{4}{ }^{2-}$, a qual deverá permanecer próxima de 0,67 caso o objetivo do tratamento seja a oxidação da matéria orgânica predominantemente pela via de redução do sulfato (LENS et al., 1998). Em relações $\mathrm{DQO} / \mathrm{SO}_{4}{ }^{2-}$ menores que 0,67 , a quantidade de matéria orgânica disponível é insuficiente para a completa redução do sulfato, a qual só poderá ser obtida com a adição de mais doadores de elétrons. Já para relações maiores de 0,67, a matéria orgânica só será completamente degradada se, além da sulfetogênese, a metanogênese também ocorrer (OMIL et al., 1998).

A relação $\mathrm{DQO} / \mathrm{SO}_{4}{ }^{2-}$ de 0,67 obedece à estequiometria da reação de oxidação completa da matéria orgânica pela via da redução do sulfato. De fato, em relações DQO/sulfato mais restritivas, próximas da relação estequiométrica de 0,67 , toda a matéria orgânica disponível poderia ser utilizada nas reações de redução de sulfato (LENS et al., 1998). Todavia, essa relação teórica assume que todo metabolismo das BRS seria dirigido para a via de oxidação completa da matéria orgânica (Equações (3.7), (3.8) e (3.9); oxidação completa de hidrogênio, acetato e etanol, respectivamente) (MUYZER; STAMS, 2008), o que nem sempre ocorre na prática. Geralmente, em reatores anaeróbios, a redução de sulfato se dá principalmente pela via da oxidação incompleta da matéria orgânica, com geração de acetato (Equações (3.10), (3.11), (3.12) e (3.13); oxidação parcial de etanol, propionato, butirato e lactato, respectivamente) (ZHOU; XING, 2015; DAMIANOVIC; FORESTI, 2007). Nesse caso, a demanda por doador de elétrons é maior, e a operação do sistema em relações próximas de 0,67 pode implicar no estabelecimento de competição entre os diversos grupos 
de BRS pela matéria orgânica disponível, além da inibição da metanogênese (YAMAGUCHI, et al., 1999; CHOI; RIM, 1991). Como resultado, são obtidas menores eficiências de remoção de matéria orgânica e sulfato (VILELA et al., 2014; VELASCO et al., 2008; DAMIANOVIC; FORESTI, 2007).

$$
\begin{aligned}
& \mathrm{SO}_{4}^{-2}+4 \mathrm{H}_{2}+\mathrm{H}^{+} \rightarrow 4 \mathrm{H}_{2} \mathrm{O}+\mathrm{HS}^{-} \\
& \Delta \mathrm{G}^{\mathrm{o}}=-151,9 \mathrm{~kJ} / \text { reação } \\
& \mathrm{SO}_{4}^{-2}+\mathrm{CH}_{3} \mathrm{COO}^{-} \rightarrow 2 \mathrm{HCO}_{3}^{-}+\mathrm{HS}^{-} \\
& \Delta \mathrm{G}^{\mathrm{o}}=-47,6 \mathrm{~kJ} / \text { reação } \\
& 3 \mathrm{SO}_{4}^{-2}+2 \mathrm{CH}_{3} \mathrm{CH}_{2} \mathrm{OH} \rightarrow 4 \mathrm{HCO}_{3}^{-}+2 \mathrm{H}_{2} \mathrm{O}+\mathrm{H}^{+}+3 \mathrm{HS}^{-} \\
& \Delta \mathrm{G}^{\mathrm{o}}=-227,3 \mathrm{~kJ} / \text { reação } \\
& \mathrm{SO}_{4}{ }^{-2}+2 \mathrm{CH}_{3} \mathrm{CH}_{2} \mathrm{OH} \rightarrow 2 \mathrm{CH}_{3} \mathrm{COOH}+2 \mathrm{H}_{2} \mathrm{O}+\mathrm{S}^{-2} \\
& \Delta \mathrm{G}^{\mathrm{o}}=-22 \mathrm{~kJ} / \text { reação } \\
& 0,75 \mathrm{SO}_{4}^{-2}+\mathrm{CH}_{3} \mathrm{CH}_{2} \mathrm{COO}^{-} \rightarrow \mathrm{CH}_{3} \mathrm{COO}^{-}+\mathrm{HCO}_{3}^{-}+0,25 \mathrm{H}^{+}+0,75 \mathrm{HS}^{-} \\
& \Delta \mathrm{G}^{\mathrm{o}}=-37,7 \mathrm{~kJ} / \text { reação } \\
& 0,5 \mathrm{SO}_{4}^{-2}+\mathrm{CH}_{3} \mathrm{CH}_{2} \mathrm{CH}_{2} \mathrm{COO}^{-} \rightarrow 2 \mathrm{CH}_{3} \mathrm{COO}^{-}+0,5 \mathrm{H}^{+}+0,5 \mathrm{HS}^{-} \\
& \Delta \mathrm{G}^{\mathrm{o}}=-27,8 \mathrm{~kJ} / \text { reação } \\
& 0,5 \mathrm{SO}_{4}^{-2}+\mathrm{CH}_{3} \mathrm{CHCOO}^{-} \rightarrow \mathrm{CH}_{3} \mathrm{COO}^{-}+\mathrm{HCO}_{3}^{-}+0,5 \mathrm{HS}^{-} \\
& \Delta \mathrm{G}^{\mathrm{o}}=-80,2 \mathrm{~kJ} / \text { reação }
\end{aligned}
$$

Por sua vez, o acúmulo do ácido acético em sistemas exclusivamente sulfetogênicos tem sido amplamente reportado na literatura (BERTOLINO et al., 2012; CELIS-GARCIA et 
al., 2007; SAHINKAYA et al., 2007; YAMAGUCHI et al., 1999). Esta ocorrência já foi observada nos sistemas de tratamento de DAM operando com relações DQO/sulfato próximas de 0,67 , uma vez que sob esta relação a quantidade de elétrons disponível para as oxidadoras incompletas não seria suficiente para a redução de todo o sulfato presente no reator (RODRIGUEZ, 2010). Vale ressaltar também que, conforme apontam alguns estudos, o estabelecimento de BRS oxidadoras do acetato em reatores anaeróbios é de difícil obtenção (CAO et al., 2012; LENS et al., 2002; OMIL et al., 1998).

Uma estratégia para reduzir essa limitação é a operação de sistemas sulfetogênicos em relações $\mathrm{DQO} / \mathrm{SO}_{4}{ }^{2-}$ mais elevadas, por meio de fornecimento de substrato orgânico em excesso (SAHINKAYA; GUNGOR, 2010), proporcionando o estabelecimento da metanogênese concomitantemente à sulfetogênese (CHOI; RIM, 1991).

O alcance da relação de sinergia entre bactérias redutoras de sulfato geradoras de acetato e arqueias metanogênicas acetoclásticas já foi demonstrado na prática (GODOI et al., 2015; VILELA et al., 2014), o que possibilita o alcance de elevadas eficiências de remoção de DQO, pela manutenção das concentração de ácido acético sob controle, além do ganho advindo da produção do metano.

\subsection{Microbiologia das bactérias redutoras de sulfato}

As bactérias redutoras de sulfato (BRS) compreendem um grupo de microrganismos procariontes capazes de realizarem a redução dissimilativa do íon sulfato (ou outras formas oxidadas de enxofre), a qual consiste na utilização do sulfato como aceptor final de elétrons no processo de respiração anaeróbia. Nesse metabolismo, o sulfeto, como resultado final da redução do sulfato, é excretado para o meio (MADIGAN et al., 2000). A redução do sulfato a sulfeto ocorre através de uma sequência de reações através das quais 8 moles de elétrons são 
transferidos a partir do doador de elétrons (o qual pode consistir de um composto orgânico ou hidrogênio molecular) para cada 1 mol de sulfato reduzido (LENS et al., 1998).

Partindo-se das características morfológicas e fisiológicas, as BRS podem ser divididas, conforme HOLT et al. (1994), em quatro subgrupos principais:

- Subgrupo 1) BRS gram-positivas formadoras de esporos, do gênero Desulfotomaculum, os quais se apresentam na forma de bacilos retos ou ligeiramente curvados, encontrados principalmente no solo, sendo capazes de resistirem à altas temperaturas e à falta de água pela formação de endósporos. São estritamente anaeróbias, podendo ser autotróficas ou heterotróficas. Nesse último caso, hidrogênio é utilizado no metabolismo como fonte de energia enquanto o acetato é requerido como fonte de carbono. Podem utilizar sulfato, tiossulfato ou sulfito como aceptores finais de elétrons;

- Subgrupo 2) BRS não formadoras de endósporos e oxidadoras incompletas de substratos orgânicos até acetato. Podem utilizar enxofre elementar $\left(\mathrm{S}^{0}\right)$, sulfato, sulfito ou tiossulfato como aceptores finais de elétrons. Podem apresentar morfologias ovais, formato de bacilos, de espirais ou vibriões, sendo dotadas ou não de mobilidade (flagelo). Abarcam os gêneros Desulfobubus, Desulfomicrobium, Desulfomonas, Desulfovibrio e Thermodesulfobacterium;

- Subgrupo 3) BRS não formadoras de endósporos que oxidam completamente compostos orgânicos variados até $\mathrm{CO}_{2}$. Reduzem sulfato, sulfito ou tiossulfato a sulfeto. As células desses microrganismos podem apresentar formatos esféricos ou ovalados (gênero Desulfococcus), formato de bacilos retos ou curvos (gêneros Desulfomonile e Desulfobacter), bacilos curvados ou vibriões (gênero Desulfobacterium), sarcinas (gênero Desulfosarcina) ou em arranjos filamentosos (gênero Desulfonema). Além de bactérias, as únicas arqueas 
termofílicas redutoras de sulfato conhecidas (gênero Archaeglobus) também estão incluídas neste subgrupo;

- Subgrupo 4) Constituído pelos microrganismos capazes de reduzir apenas enxofre elementar $\left(S^{0}\right)$ a sulfeto. Caracterizados por estritamente anaeróbios, apresentam morfologia de bacilos retos ou ovalados e são geralmente dotadas de flagelo lateral. Neste subgrupo encontram-se os indivíduos dos gêneros Desulfurella e Desulforomonas, os quais são geralmente observados em fontes geotermais ou habitando sedimentos marinhos, respectivamente.

Já do ponto de vista das análises comparativas do RNA ribossomal 16s (RNAr 16S), as BRS conhecidas podem ser classificadas em 7 linhagens filogenéticas distintas, sendo 5 linhagens pertencentes ao Domínio Bacteria e duas ao Domínio Archaea (MUYZER; STAMS, 2008). A maioria dos organismos redutores de sulfato, divididos aproximadamente em 23 gêneros (entre os quais estão as BRS mesófilas dos gêneros Desulfovibrio, Desulfobacterium, Desulfomicrobium e Desulfomonile), estão incluídos na classe Deltaproteobacteria. Na sequência, as BRS gram-positivas (gêneros Desulfotomaculum, Desulfosporosinus e Desulfosporomusa) são agrupadas dentro da classe Clostridia. Três linhagens (dentro das classes Nitrospirae, Thermodesulfobacteria e Thermodesulfobiaceae) são caracterizadas por possuírem apenas BRS termofílicas (gêneros Thermodesulfovibrio, Thermodesulfobacterium e Thermodesulfobium, respectivamente). Já as arqueas redutoras de sulfato são classificadas dentro das classes Euryarchaeota (gênero Archaeoglobus) e Crenarchaeota (gêneros Thermocladium e Caldirvirga).

De fato, as BRS se caracterizam não só pela alta diversidade de espécies, mas também pela sua versatilidade nutricional e ambiental. Além da capacidade de utilizarem diversos doadores de elétrons (COLLERAN et al., 1995) e diferentes aceptores de elétrons $\left(\mathrm{S}^{0}, \mathrm{SO}_{4}{ }^{2-}\right.$, $\mathrm{SO}_{3}{ }^{2-}$ e $\mathrm{S}_{2} \mathrm{O}_{3}{ }^{2-}$ ), são capazes de sobreviver na ausência de compostos oxidados de enxofre 
graças à sua versatilidade metabólica. Piruvato, lactato e etanol, por exemplo, são compostos orgânicos facilmente fermentados por BRS (LENS et al., 1998; WIDDEL, 1988). Por causa de tais características, as BRS são praticamente onipresentes, podendo ser encontradas nos mais diversos habitats, naturais ou antrópicos, nos quais haja presença de sulfato, mesmo sob condições extremas de temperatura, umidade, $\mathrm{pH}$ e oxigênio (MUYZER; STAMS, 2008).

BRS já foram observadas em sedimentos marinhos, fontes termais, vulcões, poços de petróleo, na rizosfera de plantas, em aquíferos, ambientes hipersalinos e oxigenados, em meios extremamente ácidos, tais como em drenagens ácidas de minas, e em lagoas alcalinas (MUYZER; STAMS, 2008; LENS et al., 1998).

Além da importância fundamental dos microrganismos redutores de sulfato para o ciclo do enxofre, BRS também são importantes para a regulação do funcionamento de diversos ecossistemas e para a viabilidade de processos de remediação ambiental, de modo que o interesse pelo estudo desses organismos tem crescido significativamente nas últimas décadas (CASTRO et al., 2000).

\subsection{Configurações de reatores aplicados à recuperação de metais}

O tratamento biológico de DAM pode ser de natureza passiva ou ativa. Os tratamentos passivos de drenagens superficiais consistem de leitos de infiltração, lagoas anóxicas ou wetlands. Já para águas subterrâneas contaminadas por DAM podem ser utilizadas as estratégias de injeção de substrato ou barreiras permeáveis reativas. O objetivo desse tipo de tratamento é o enriquecimento da atividade dos microrganismos redutores de sulfato in situ (KAKSONEN; PUHAKKA 2007; GAZEA et al., 1996). Apesar de consideradas soluções com baixo custo de operação e manutenção, as maiores desvantagens do tratamento passivo são relacionadas com a dificuldade de controle do processo devido às variações sazonais nas 
condições ambientais, as extensas áreas demandadas para realização do tratamento e a dificuldade na recuperação de metais (KAKSONEN; PUHAKKA 2007).

Já as alternativas de tratamento ativo dizem respeito à aplicação de biorreatores, os quais são mais compactos, possibilitam maior controle operacional do processo e facilitam a recuperação dos sulfetos metálicos, apesar dos altos custos associados com a instalação e manutenção do sistema (KAKSONEN; PUHAKKA 2007).

Diversas configurações de reatores anaeróbios já foram testadas para o tratamento de DAM em condições sulfetogênicas, acoplados ou não à recuperação de metais, tais como reatores UASB (RODRIGUEZ et al., 2012; LENZ et al., 2008), filtros anaeróbios (ELLIOT et al., 1998), reatores compartimentados (BEKMEZCI et al., 2011), reatores de leito expandido (SIERRA-ALVAREZ et al., 2007) e reatores de leito fluidizado (SAHINKAYA et al., 2007).

Em reatores biológicos de um único estágio (por exemplo, reatores de leito fixo) operados em faixas de $\mathrm{pH}$ próximas da neutralidade, os metais podem ser precipitados sob a forma de sulfetos insolúveis, mas esta configuração não permite uma separação efetiva dos metais precipitados, os quais permanecem em contato com a biomassa, podendo aderir ao material suporte ou biofilme (VILLA-GOMEZ et al., 2011; GALLEGOS-GARCIA et al., 2009). O depósito de sulfeto metálico nas biopartículas pode resultar na inibição da atividade sulfetogênica pela toxicidade dos metais depositados ou ainda por prejudicar os processos de transferência de massa no sistema (VILLA-GOMEZ et al., 2011; UTGIKAR et al., 2002).

Outras configurações propostas para a recuperação de metais consistem em reatores de duas ou mais fases, nos quais os processos de redução do sulfato e produção de sulfeto ocorrem em um reator, e a precipitação dos metais ocorre em câmaras separadas. Essa configuração possibilita a recuperação de diferentes metais de forma segregada por meio da recirculação do efluente líquido do reator sulfetogênico (contendo sulfeto dissolvido e alcalinidade para precipitação de ferro, por exemplo) ou do biogás produzido (contendo 
sulfeto gasoso para a precipitação de zinco e cobre em baixos valores de $\mathrm{pH}$, por exemplo) (XINGYU et al., 2013; UCAR et al., 2011; JIMÉNEZ-RODRIGUEZ et al., 2009).

Um problema observado em sistemas em série, nos quais se realiza a injeção de efluente ou do biogás rico em sulfeto em uma câmara separada para a precipitação dos metais, diz respeito à formação de pequenas partículas de sulfetos metálicos, com baixa sedimentabilidade. Isso ocorre devido ao estabelecimento de gradientes de concentrações de sulfeto no meio líquido, sendo altas as concentrações no entorno da entrada da corrente rica em sulfeto (ESPOSITO et al., 2006; VEEKEN et al., 2003a, b). Nessas regiões com altas concentrações de sulfeto, altas taxas de formação de sulfetos metálicos também são obtidas, o que concorre para a formação de partículas menores (MERSMANN, 1999). Por outro lado, quando as concentrações de sulfeto são menores, as taxas de nucleação (formação de novas partículas) também são baixas, proporcionando a formação de cristais maiores, com melhores qualidades de sedimentação. Assim, quanto mais homogênea a concentração de sulfeto, o que pode ser facilmente obtido em reatores de fase única, mais favorável as condições para a formação de partículas de sulfetos metálicos de fácil separação (SÁNCHEZ-ANDREA et al., 2014).

Dessa forma, o conceito de reatores de único estágio para o estabelecimento simultâneo dos processos de redução de sulfato e precipitação de metais se mostra uma estratégia mais desejável para potencializar a sedimentação e posterior recuperação dos metais de interesse. Além dos menores custos com instalação e operação de reatores em único estágio, também devem ser destacado o fato de não ser necessário o transporte ou canalização das correntes ricas em sulfeto, o que já seria dificultoso pelas suas características fortemente corrosivas. Aliado a isso tem-se a manutenção de menores concentrações residuais de sulfeto dissolvido no meio líquido do biorreator, contornando-se assim os problemas de inibição da biomassa sulfetogênica (SÁNCHEZ-ANDREA et al., 2014). 
Uma configuração que tem sido testada com êxito, não só para a precipitação de metais, mas também para a sua recuperação no tratamento de DAM, é o reator de leito fluidizado de fluxo descendente, ou reator de leito fluidizado inverso (CELIS-GARCIA et al., 2007). Nessa configuração o material suporte flutua no topo do reator e a fluidização é obtida pela recirculação do efluente de forma descendente. Outra vantagem do reator de leito fluidizado inverso são suas altas velocidades superficiais do escoamento, o que evita a deposição de sulfetos metálicos diretamente sobre a biomassa. Assim, durante o processo, os metais que precipitam sob a forma de sulfetos insolúveis são arrastados para o fundo do reator, onde poderão ser retirados e recuperados em seguida (SAHINKAYA; GUNGOR, 2010; GALLEGOS-GARCIA et al., 2009).

Um inconveniente desta configuração de reator, que o torna menos atraente para aplicações em escala real, são os altos gastos energéticos, em função das altas vazões de recirculação requeridas para a fluidização permanente do leito, um problema inerente aos reatores de leito fluidizado (RAJESHWARI et al., 2000). De fato, as razões de reciclo em reatores de leito fluidizado inverso podem chegar até 600 vezes a vazão de alimentação (GALLEGOS-GARCIA et al., 2009).

Por outro lado, o reator anaeróbio de leito fixo-estruturado (AFSBR), recentemente apresentado (MOCKAITIS, 2011), tem potencial de se tornar uma alternativa economicamente viável para o tratamento de drenagens ácidas de minas com recuperação de metais. $\mathrm{O}$ arranjo do leito fixo-estruturado consiste em estruturar o material suporte em hastes verticais equidistantes ao longo do comprimento do leito, mantendo uma área transversal de escoamento livre. Esta configuração de reator apresenta como principais vantagens a diminuição do acúmulo de sólidos, ocorrência comum em reatores de leito fixo empacotados, nos quais o material suporte é acondicionado de maneira aleatória. No AFSBR, problemas como o entupimento do leito e caminhos preferências de escoamento podem ser evitados, 
graças ao processo de autorregulação do biofilme pelas forças de cisalhamento (LAZAROVA; MANEM, 1995), as quais são proporcionadas pelas velocidades superficiais de escoamento no sistema (MOCKAITIS et al., 2014). O reator de leito fixo-estruturado já foi inclusive aplicado com sucesso no tratamento anaeróbio de águas residuárias orgânicas ricas em sulfato (GODOI et al., 2015; CAMILOTI et al., 2013) e na remoção de metais pesados (Chumbo e Cádmio) de uma água residuária sintética (MOCKAITIS et al., 2012).

Uma inovação proposta por este trabalho para o tratamento de DAM em reator de leito fixo-estruturado é a aplicação do fluxo descendente, com o objetivo de se proporcionarem melhores condições de separação dos sulfetos metálicos formados, os quais serão arrastados pelo escoamento descendente para a câmara inferior do sistema, livre de material suporte, da qual poderão serão retirados. Originalmente, o reator de leito fixo-estruturado e fluxo descendente (down-flow fixed-structured bed reactor - DFSBR) foi testado para a produção de hidrogênio a partir da fermentação da sacarose visando à manutenção de altas cargas orgânicas específicas, o que é mais facilmente obtido nessa configuração devido ao arraste de biomassa para o fundo do reator pelas velocidades descensionais do escoamento (ANZOLAROJAS et al., 2016; ANZOLA-ROJAS; ZAIAT, 2015).

Outra modificação dessa configuração consiste na aplicação de uma razão de recirculação que, apesar de menor que as razões geralmente aplicadas em reatores de leito fluidizado inverso, o que visa contribuir com os processos de regulação da espessura do biofilme e minimizar a deposição dos metais precipitados sobre a biomassa ou a sua adesão ao material suporte.

\subsection{Contribuição do íon bissulfeto na alcalinidade de reatores anaeróbios}

As DAM são caracterizadas pelos baixos valores de pH (AKCIL; KOLDAS 2006), de forma que uma das vantagens do tratamento anaeróbio mediado por BRS diz respeito à 
neutralização do efluente pela produção de alcalinidade no processo de redução biológica de sulfato (Equação (3.5)), aliada com a imobilização dos metais pesados, que reagem com o sulfeto em solução (JOHNSON; HALLBERG 2005).

Por outro lado, uma vez que o tratamento anaeróbio é fortemente dependente do pH do meio líquido para a manutenção de adequada atividade dos microrganismos (CALLANDER et al., 1983), é ideal que sistemas anaeróbios sejam capazes de resistir à bruscas variações do $\mathrm{pH}$, o que é garantido pela alcalinidade a bicarbonato. De fato, o íon bicarbonato é o maior responsável por prover o tamponamento suficiente exigido por esses sistemas, permitindo a manutenção do $\mathrm{pH}$ na faixa adequada para o metabolismo dos microrganismos envolvidos (CHERNICHARO, 2007). De fato, na ausência de alcalinidade suficiente (seja internamente produzida ou adicionada como fonte externa), a produção de ácidos voláteis pode resultar na acidificação do meio reacional com inibição da biomassa (AQUINO; CHERNICHARO, 2005).

Embora uma fração importante de alcalinidade na faixa de $\mathrm{pH}$ usualmente adotada para reatores anaeróbios (entre 6,0 e 8,0) seja garantida pela concentração do íon bicarbonato $\left(\mathrm{HCO}_{3}{ }^{-}\right)$, outros aceptores de prótons $\left(\mathrm{H}^{+}\right)$também podem contribuir com a alcalinidade total do sistema, tais como a hidroxila $\left(\mathrm{OH}^{-}\right)$, os ânions fosfato $\left(\mathrm{PO}_{4}{ }^{3-}\right)$ e bissulfeto (HS $\left.{ }^{-}\right)$(WOLFGLADROW et al., 2007).

De fato, o sulfeto biologicamente gerado a partir do metabolismo das BRS é encontrado predominantemente na fase líquida, distribuído entre a forma molecular (sulfeto de hidrogênio dissolvido $-\mathrm{H}_{2} \mathrm{~S}$ ) e as formas iônicas, seja como íon bissulfeto ou hidrogenossulfeto $\left(\mathrm{HS}^{-}\right)$, seja como íon dissulfeto ( ${ }^{2-}$ ) (LEWIS, 2010). Essa distribuição é dependente do pH da solução, conforme mostrado na Figura 3.3. 


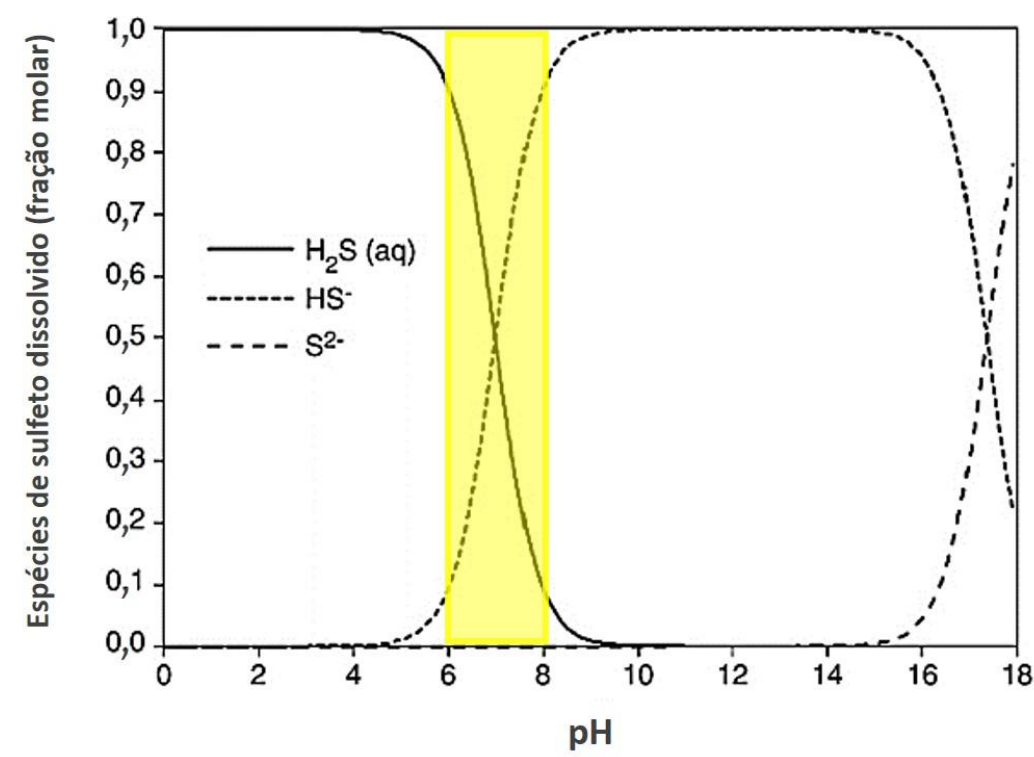

Figura 3.3: Distribuição das espécies de sulfeto em função do $\mathrm{pH}$ com destaque da faixa ótima para a digestão anaeróbia.

Fonte: LEWIS, 2010; LENS et al., 2008.

Uma vez em solução, o sulfeto atua como um ácido fraco, dissociando-se conforme as reações mostradas nas equações (3.14) e (3.15) a seguir (LEWIS, 2010):

$$
\begin{array}{ll}
\mathrm{H}_{2} \mathrm{~S}_{(\mathrm{aq})} \leftrightharpoons \mathrm{HS}^{-}+\mathrm{H}^{+} & \mathrm{pKa}^{1}=6.99 \\
\mathrm{HS}^{-} \leftrightharpoons \mathrm{S}^{2-}+\mathrm{H}^{+} & \mathrm{pKa}^{2}=17.4
\end{array}
$$

$\mathrm{O}$ valor do $\mathrm{pKa}^{2}$ referente à segunda dissociação (Equação (3.14)) é controverso, com valores obtidos na literatura entre 13 e 19 (MYERS, 1986). De qualquer forma, na faixa de pH próxima da neutralidade, na qual são usualmente operados os sistemas anaeróbios (Figura 3.3), apenas a primeira dissociação pode ser considerada relevante. Já com relação à dissociação do primeiro par $\left(\mathrm{H}_{2} \mathrm{~S} / \mathrm{HS}^{-}\right)$, com $\mathrm{pKa}^{1}$ próximo de 6,99 em condições ambientais de temperatura e pressão $\left(25^{\circ} \mathrm{C}\right.$ e $\left.1 \mathrm{~atm}\right)$, alta fração do íon bissulfeto serão encontradas no 
meio líquido, o que implica em uma porção significativa de alcalinidade devida à habilidade do $\mathrm{HS}^{-}$em neutralizar os íons $\mathrm{H}^{-}$para produzir o sulfeto de hidrogênio molecular (Equação (3.15)) (GODOI et al., 2017b).

A manutenção de adequada capacidade tampão no meio líquido se faz necessária para garantir a robustez de um sistema anaeróbio, o qual depende do equilíbrio entre diversos metabolismos realizados por bactérias acidogênicas, acetogênicas, redutoras de sulfato por arqueias metanogênicas. Dessa forma, o monitoramento da alcalinidade do reator biológico é essencial para a adequada operação desses sistemas, de forma a ser possível uma rápida tomada de decisão para evitar o seu colapso devido ao eventual acúmulo de ácidos orgânicos (CHERNICHARO, 2007). Tais determinações são convencionalmente realizadas por meio de procedimentos titulométricos, que se baseiam na titulação de uma amostra do efluente do reator com um ácido forte (APHA/AWWA/WEF, 2005; RIPLEY et al., 1986). Ainda que esses métodos sejam capazes de determinar a capacidade tampão do sistema, os resultados da titulação não levam em conta a contribuição do sulfeto dissolvido, a qual é medida concomitantemente com o bicarbonato ao longo da titulação. Essa limitação se torna mais significativa em reatores nos quais a sulfetogênese apresenta uma participação substancial no processo de remoção da matéria orgânica, pela maior produção de sulfeto.

De acordo com a Equação (3.16) a seguir, considerando o ferro como exemplo, a precipitação de $1 \mathrm{~mol}$ desse metal com o sulfeto implica tanto na geração de $1 \mathrm{~mol}$ de acidez $\left(\mathrm{H}^{+}\right)$assim como resulta no consumo de 1 mol do ânion $\mathrm{HS}^{-}$, anteriormente disponível em solução (GALLEGOS-GARCIA et al., 2009).

$$
\mathrm{HS}^{-}+\mathrm{Fe}^{2+} \leftrightharpoons \mathrm{FeS} \downarrow+\mathrm{H}^{+}
$$


Nesse contexto, torna-se importante diferenciar as frações de alcalinidade devidas ao $\mathrm{HS}^{-}$aquoso, o qual é diretamente removido pelo mecanismo de precipitação de metais, da fração de alcalinidade devida ao bicarbonato, consumido pela liberação de prótons. Ignorar a perda potencial de alcalinidade pela precipitação dos sulfetos metálicos pode resultar na instabilidade do reator anaeróbio, devida ao déficit resultante na capacidade tampão do meio. Por outro lado, não levar em conta a contribuição do sulfeto para o incremento da alcalinidade do efluente tratado também poderá implicar na superestimação do bicarbonato produzido pelo metabolismo microbiano. Até agora, a contribuição do sulfeto e o seu papel na alcalinidade de reatores sulfetogênicos não foi profundamente explorada. Tendo isso em vista, o presente trabalho também visou avaliar a alcalinidade devida a sulfeto no efluente do DFSBR tratando uma DAM sintética com precipitação de sulfetos metálicos induzida pelo aumento gradual da carga de ferro aplicada. 


\section{MATERIAL E MÉTODOS}

\subsection{Delineamento experimental}

O estudo do reator de leito fixo-estruturado e fluxo descendente (DFSBR) aplicado ao tratamento de DAM sintética utilizando vinhaça como fonte de carbono e doador de elétrons se estendeu por 17 fases operacionais, as quais foram agrupadas em 3 etapas.

A água residuária utilizada durante a primeira etapa experimental (ETAPA 1) consistiu de um efluente sintético simulando a mistura das duas águas residuárias em questão, sendo a primeira uma drenagem ácida de minas (DAM) rica em ferro, e a segunda a fração solúvel da vinhaça de cana-de-açúcar, utilizada como doador de elétrons, fonte de carbono e nutrientes para a redução de sulfato e produção de metano. Durante as etapas posteriores (ETAPAS 2 e 3) o sistema foi testado no tratamento de uma DAM sintética em conjunto com vinhaça de cana-de-açúcar concentrada, proveniente de usina de produção de açúcar e etanol.

Cada etapa de operação está relacionada a um objetivo específico e baseada nas suas respectivas sub-hipóteses, como anteriormente descrito (seção 2.2, p. 31). A Tabela 4.1 apresenta resumidamente as condições testadas em cada etapa, subdivididas nas 17 fases operacionais do estudo.

Convém ressaltar que, apesar da alta variabilidade de composição observada em drenagens ácidas de minas (Tabela 3.1), e embora diversos elementos metálicos sejam encontrados nas DAM, optou-se por conduzir o presente estudo utilizando-se uma DAM sintética de composição simplificada, contendo apenas ferro como metal de referência, o qual é usualmente o componente metálico de maior concentração na água residuária em questão (LOPES, 2011). O ferro ferroso $\left(\mathrm{Fe}^{2+}\right)$, por sua vez, por não apresentar toxicidade expressiva sobre microrganismos redutores de sulfato e metanogênicos (MUDHOO; KUMAR, 2013; TABAK et al., 2004), possibilitou a aplicação de concentrações crescentes desse metal numa 
ampla faixa (até $400 \mathrm{mg} \cdot \mathrm{L}^{-1}$ ), permitindo a investigação do potencial de formação e precipitação de sulfetos metálicos no DFSBR sob diversas cargas de metal aplicadas. Finalmente, uma vez que os sulfetos de ferro apresentam coeficientes de solubilidade (Kps) maiores que os de outros metais presentes em DAM (LEWIS, 2010), espera-se que os resultados positivos obtidos ao longo da operação do DFSBR sejam replicados em estudos posteriores, focados na precipitação e separação de outros metais de interesse. 
Tabela 4.1: Condições operacionais empregadas ao longo das etapas do estudo.

\begin{tabular}{|c|c|c|c|c|c|c|c|c|c|c|c|c|c|c|c|c|c|}
\hline \multirow{3}{*}{ Parâmetros } & \multirow{2}{*}{\multicolumn{5}{|c|}{ ETAPA 1}} & \multirow{2}{*}{\multicolumn{5}{|c|}{ ETAPA 2}} & \multirow{2}{*}{\multicolumn{7}{|c|}{ ETAPA 3}} \\
\hline & & & & & & & & & & & & & & & & & \\
\hline & $\mathbf{1 A}$ & 1B & $1 \mathrm{C}$ & $1 D$ & $1 E$ & $2 \mathrm{~A}$ & 2B & $2 \mathrm{C}$ & 2D & $2 \mathbf{E}$ & $\mathbf{3 A}$ & 3B & $3 \mathrm{C}$ & 3D & $3 E$ & $3 F$ & 3G \\
\hline DQO (mg.L $\left.{ }^{-1}\right)$ & \multicolumn{5}{|c|}{$4025 \pm 190$} & \multicolumn{5}{|c|}{$4000 \pm 440$} & \multicolumn{7}{|c|}{$4100 \pm 450$} \\
\hline $\mathrm{DQO} / \mathrm{SO}_{4}{ }^{2-}$ & \multicolumn{5}{|c|}{$2,0 \pm 0,2$} & \multicolumn{5}{|c|}{$2,0 \pm 0,3$} & \multicolumn{7}{|c|}{$1,9 \pm 0,2$} \\
\hline TDH (h) & \multicolumn{5}{|c|}{$20 \pm 1$} & \multicolumn{5}{|c|}{$21 \pm 2$} & \multicolumn{7}{|c|}{$21 \pm 2$} \\
\hline pH afluente & \multicolumn{5}{|c|}{$6,1 \pm 0,1$} & \multicolumn{5}{|c|}{$6,1 \pm 0,2$} & $\begin{array}{c}6,3 \\
\pm 0,4\end{array}$ & $\begin{array}{c}6,0 \\
\pm 0,1\end{array}$ & $\begin{array}{c}5,4 \\
\pm 0,1\end{array}$ & $\begin{array}{c}5,0 \\
\pm 0,1\end{array}$ & $\begin{array}{c}4,6 \\
\pm 0,1\end{array}$ & $\begin{array}{c}4,0 \\
\pm 0,1\end{array}$ & $\begin{array}{c}3,5 \\
\pm 0,1\end{array}$ \\
\hline $\begin{array}{l}\text { Ferro afluente } \\
\left(\text { mg.L }^{-1}\right)\end{array}$ & $\begin{array}{c}2 \\
\pm 1\end{array}$ & $\begin{array}{l}55 \\
\pm 5\end{array}$ & $\begin{array}{r}110 \\
\pm 10\end{array}$ & $\begin{array}{l}220 \\
\pm 15\end{array}$ & $\begin{array}{l}400 \\
\pm 70\end{array}$ & $2 \pm 1$ & \multicolumn{4}{|c|}{$310 \pm 60$} & $2 \pm 1$ & \multicolumn{6}{|c|}{$260 \pm 40$} \\
\hline $\begin{array}{l}\text { Tempo de } \\
\text { Operação }\end{array}$ & \multicolumn{5}{|c|}{277 dias } & \multicolumn{5}{|c|}{100 dias } & \multicolumn{7}{|c|}{170 dias } \\
\hline
\end{tabular}

Fonte: $\mathrm{O}$ autor. 


\subsubsection{ETAPA 1 -Referente ao objetivo específico 1}

Durante a ETAPA 1 pretendeu-se avaliar a aplicação do reator DFSBR para o tratamento biológico de uma água residuária rica em sulfato e ferro (DAM sintética), utilizando um substrato orgânico sintético baseado na vinhaça como doador de elétrons. O potencial de formação e precipitação de sulfetos metálicos e a sua recuperação na zona inferior de sedimentação do reator também foi avaliado.

A justificativa para a utilização de um efluente orgânico sintético durante a primeira etapa desse trabalho se deveu à necessidade de aquisição de conhecimentos fundamentais sobre os processos envolvidos. A adaptação inicial dos microrganismos e o controle das concentrações de sulfato, sulfeto e ferro foram fatores determinantes para o desenvolvimento de estudos com bases científicas que permitissem avaliar o potencial do reator DFSBR para o tratamento conjunto de DAM com vinhaça, visando à remoção e recuperação de metais.

A FASE 1A consistiu na estabilização do reator, na qual foram aplicadas as cargas orgânica e de sulfato desejadas e o sistema foi monitorado até a obtenção de estabilidade nos processos de remoção de DQO, redução de sulfato e produção de sulfeto. Durante essa fase a concentração de ferro total afluente foi mantida próxima de $2 \mathrm{mg} . \mathrm{L}^{-1}$, de forma a garantir apenas o ferro requerido como micronutriente pela biomassa. A relação DQO/sulfato foi mantida em 2,0, acima do valor estequiométrico $(0,67)$, viabilizando o estabelecimento da metanogênese concomitantemente à sulfetogênese (OMIL et al., 1998; CHOI; RIM, 1991).

Durante as FASES 1B a 1E o reator foi submetido ao aumento gradativo nas concentrações de ferro no afluente (50 a $400 \mathrm{mgFe}{ }^{2+} \cdot \mathrm{L}^{-1}$ ) para se avaliar a capacidade do reator em proporcionar a formação e a precipitação adequada de sulfetos de ferro.

A contribuição do sulfeto dissolvido para a alcalinidade total do sistema, em conjunto com a alcalinidade a bicarbonato, e o comportamento das espécies de sulfeto no reator 
submetido à precipitação de metais, foi avaliada ao longo das 5 fases operacionais testadas durante essa etapa (seção 4.7, p. 83).

Por fim, a caracterização da diversidade microbiana do inóculo e de amostras de biomassa obtidas ao início (FASE 1A) e ao final (FASE 1E) da ETAPA 1 por meio de PCR/DGGE foi efetuada (seção 4.11, p. 93).

\subsubsection{ETAPA 2 - Referente ao objetivo específico 2}

Durante a ETAPA 2 foram avaliadas diferentes razões de recirculação da fase líquida $(0,50,100$ e 150 vezes $)$ de forma a se definir a taxa de reciclo $\left(\mathrm{Q}_{\mathrm{AFL}} / \mathrm{Q}_{\mathrm{R}}\right)$, associada a sua velocidade superficial do escoamento, que garantisse maior estabilidade e eficiência do processo biológico e de formação e separação dos sulfetos de ferro no reator. A velocidade superficial do escoamento descendente em cada fase foi calculada conforme a Equação (4.1), abaixo apresentada:

$$
\mathrm{V}_{\mathrm{S}}=\frac{\mathrm{Q}}{\mathrm{A} \times \varepsilon}
$$

$\mathrm{Na}$ qual $\mathrm{V}_{\mathrm{S}}$ é a velocidade superficial do escoamento $\left(\mathrm{m} . \mathrm{h}^{-1}\right)$; Q é a vazão total de líquido considerando as vazões afluente $\left(\mathrm{Q}_{\mathrm{AFL}}\right)$ e de reciclo $\left(\mathrm{Q}_{\mathrm{R}}\right)\left(\mathrm{m}^{3} \cdot \mathrm{h}^{-1}\right)$; A é a área da seção transversal $\left(\mathrm{m}^{2}\right)$; e $\varepsilon$ é a porosidade do leito, definida como sendo o quociente entre o volume útil e o volume total do reator $(\mathrm{Vu} / \mathrm{Vt})$.

Previamente à introdução de vinhaça real no sistema, para a determinação das condições hidrodinâmicas do DFSBR, ensaios com traçador foram realizados sob as diferentes razões de reciclo, conforme detalhado na seção 4.8, p. 88. Vinhaça sintética foi utilizada durante os testes hidrodinâmicos, sem adição complementar de ferro. 
Após a realização dos ensaios hidrodinâmicos, o reator passou a ser alimentado com vinhaça real (FASE 2A) para verificar a adequação desse substrato como doador de elétrons e fonte de carbono e nutrientes para o processo. Nas fases subsequentes (FASES 2B a 2E), operadas com diferentes razões de reciclo, uma carga maior de ferro voltou a ser introduzida no sistema. A partir de então, as cargas de DQO, sulfato e ferro aplicadas permaneceram praticamente as mesmas, conforme mostrado na Tabela 4.1, e o estudo dos efeitos das diferentes razões de recirculação sobre o processo foi conduzido.

Para avaliar o efeito da velocidade superficial sobre a deposição de sulfetos metálicos no biofilme, bem como para verificar o possível arraste de biomassa, ao final de cada fase operacional dessa etapa (FASES 2B a 2E) foram retiradas amostras de material suporte, aleatoriamente coletadas, para análise de sólidos totais, fixos e voláteis, bem como para determinação das porcentagens de ferro e enxofre nas cinzas da biomassa.

Testes cinéticos para avaliação das taxas de remoção de matéria orgânica e sulfato no reator DFSBR operando em batelada a partir de diversos doadores de elétrons (vinhaça, ácidos acético, propiônico, lático e etanol) foram realizados ao final da ETAPA 2, conforme descrito na seção 4.9, p. 91.

Por fim, análise da diversidade microbiana (PCR/DGGE) de amostras dos inóculos utilizados e da biomassa coletada ao início (FASES 2A e 2B) e ao final (FASE 2E) da ETAPA 2 também foi realizada (seção 4.11, p. 93).

\subsubsection{ETAPA 3 - Referente ao objetivo específico 3}

A ETAPA 3 foi destinada ao estudo do reator alimentado com DAM sintética e vinhaça real, sendo submetido à diminuição gradativa do $\mathrm{pH}$ do afluente $(\mathrm{pH}$ AFLUENTE $=6,3$ $\rightarrow 3,5$ ), de forma a se avaliar a estabilidade do processo anaeróbio com diminuição da 
dosagem externa de álcali e o potencial do sistema para a neutralização de uma drenagem ácida de minas. Também se pretendeu verificar os efeitos do $\mathrm{pH}$ afluente (e do $\mathrm{pH}$ no meio líquido interno do reator) sobre a precipitação de sulfetos metálicos, bem como sobre o desempenho da biomassa estabelecida no reator.

Análises da diversidade microbiana obtida ao longo dessa etapa foram realizadas em amostras provenientes dos inóculos e do material suporte ao final das FASES 3A, 3B, 3E e 3G por meio da técnica PCR/DGGE (seção 4.11, p. 93). Para caracterização da comunidade microbiana estabelecida no reator e verificação das modificações sofridas pela biomassa após a supressão da dosagem de álcali no DFSBR foi realizado o sequenciamento do RNAr $16 \mathrm{~S}$ das amostras de biomassa coletadas ao final das FASES 3A e 3G (seção 4.12, p. 95).

Por fim, uma avaliação preliminar do potencial teórico de geração de energia a partir do biogás gerado pelo DFSBR também foi efetuada, para a verificação da viabilidade econômica do sistema de tratamento de uma DAM real (baseado no DFSBR) em relação aos gastos com o transporte da vinhaça.

\subsection{Reator DFSBR}

O reator de leito fixo-estruturado e fluxo descendente (down-flow fixed-structured bed reactor - DFSBR) utilizado no presente estudo consistiu de uma coluna de acrílico com $6 \mathrm{~cm}$ de diâmetro interno e altura de $70 \mathrm{~cm}$. A base do reator, de formato cônico, contou com uma saída para o descarte do material precipitado. Um compartimento de equalização de nível foi instalado na saída do efluente para manutenção do nível líquido constante no interior do reator, bem como para melhorar a retenção dos sólidos em suspensão (principalmente os sulfetos metálicos) no interior do sistema. O volume total do reator, incluindo o equalizador de nível, foi de 1,9 L, enquanto o seu volume útil foi de 1,7 L (porosidade de 89,5\%). Pontos 
de coleta de amostras foram distribuídos de forma equidistante ao longo da coluna do reator. O DFSBR foi operado com tempo de detenção hidráulica (TDH) da ordem de 20 h e mantido em câmara com temperatura controlada de $30^{\circ} \mathrm{C}$. A vazão de alimentação foi próxima de $85 \mathrm{~mL} \cdot \mathrm{h}^{-1}$ ao longo de todo o período operacional. Na Figura 4.1 tem-se uma representação esquemática do DFSBR utilizado neste estudo.

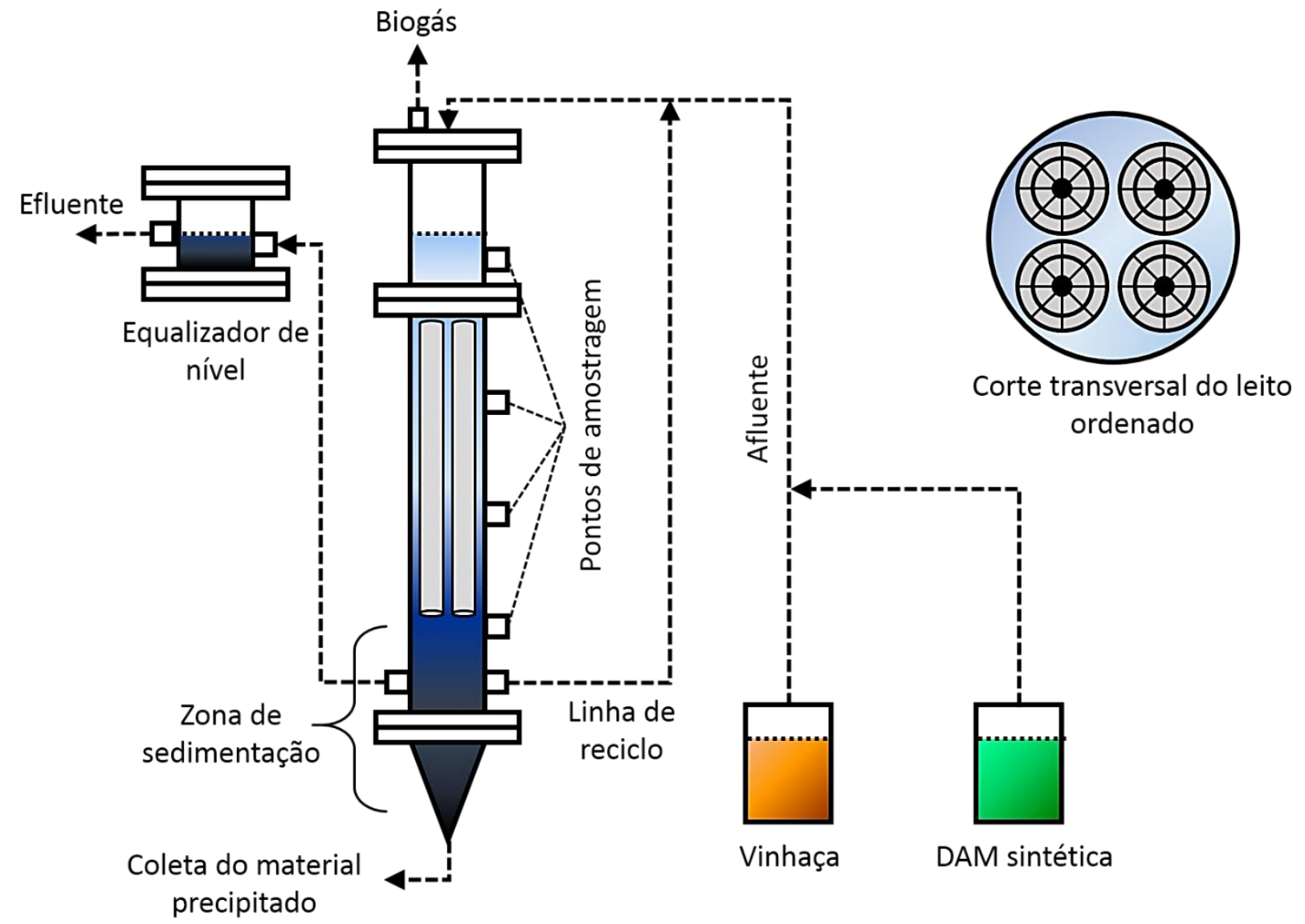

Figura 4.1: Representação esquemática do reator de leito fixo-estruturado de fluxo descendente (DFSBR) e vista transversal do leito.

Fonte: GODOI et al., 2017a.

\subsection{Material suporte e zona de sedimentação}

O material suporte consistiu de cilindros de polietileno de baixa densidade com $30 \mathrm{~mm}$ de comprimento e $25 \mathrm{~mm}$ de diâmetro cada. O material apresenta densidade de $0,96 \mathrm{~g} . \mathrm{cm}^{-3}$ e a 
sua área superficial específica é de cerca de 7,95 $\mathrm{m}^{2} \cdot \mathrm{g}^{-1}$ (PEIXOTO, 2011). Os cilindros foram acondicionados em 4 hastes verticais, dispostas ao longo do leito. Cada haste contou com 13 cilindros cada. A Figura 4.2 apresenta uma amostra do material suporte utilizado e na Figura 4.3 são mostradas as hastes do reator montadas.

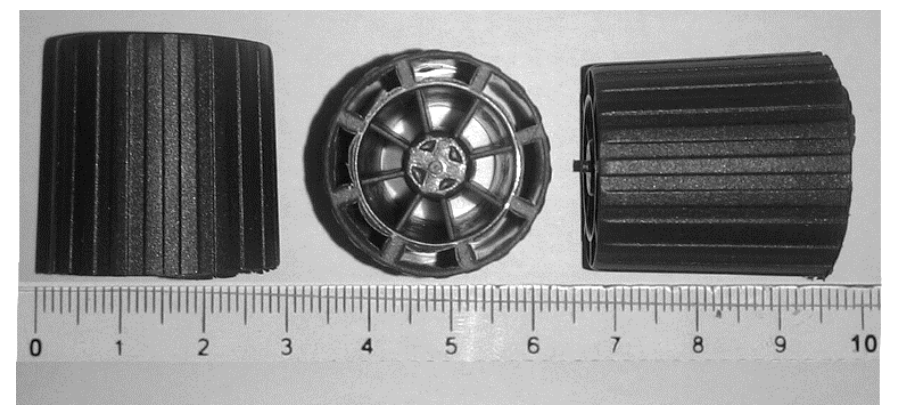

Figura 4.2: Cilindros de polietileno de baixa densidade.

Fonte: $\mathrm{O}$ autor.

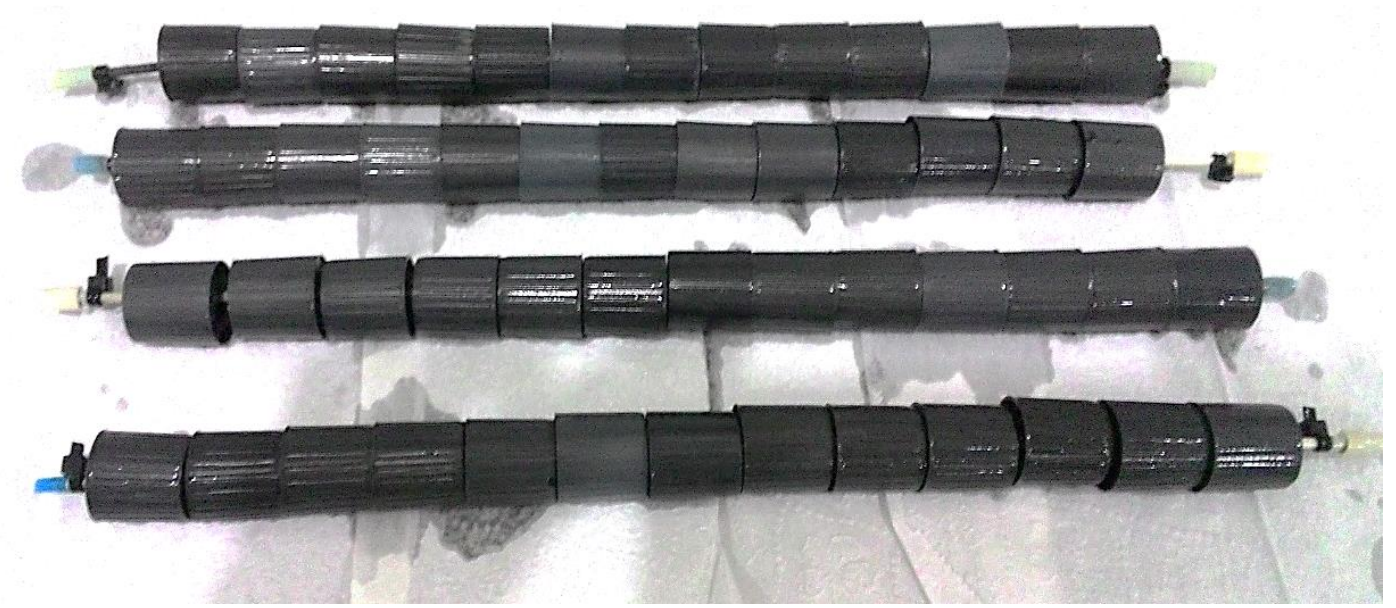

Figura 4.3: Hastes de material suporte do DFSBR.

Fonte: $\mathrm{O}$ autor.

Foi mantida uma região livre de material suporte (altura de $20 \mathrm{~cm}$ e volume aproximado de $500 \mathrm{~mL}$ ) na parte inferior do reator para a sedimentação dos sulfetos metálicos produzidos. Vale ressaltar que para efeito do cálculo do tempo de detenção hidráulico (TDH) foi considerado o volume útil do reator, levando em conta as zonas com e sem material suporte. 
Para evitar a saturação da câmara de sedimentação e visando também à recuperação dos sulfetos metálicos precipitados foram realizados descartes periódicos dessa zona do DFSBR. Durante as FASES 1A a 1D o descarte foi realizado com frequência próxima de mensal. Durante a FASE 1E a frequência do descarte foi aumentada para semanal. Em cada descarte, cerca de $500 \mathrm{~mL}$ de líquido interno rico em sulfetos metálicos era retirado do reator. Para evitar o contato da biomassa com o oxigênio atmosférico por longo período de tempo, o volume do reator era rapidamente completado com $500 \mathrm{~mL}$ de meio sintético neutralizado $(\mathrm{pH}=7,0)$. Durante as fases operacionais das ETAPAS 2 e 3 o descarte passou a ser realizado a cada 3 dias, com retirada de cerca de $150 \mathrm{~mL}$ de líquido interno do reator.

Na Figura 4.4 é apresentado o reator em operação, durante a fase sem adição complementar de ferro, permitindo a visualização da zona de sedimentação sem material suporte e os pontos de amostragem. 


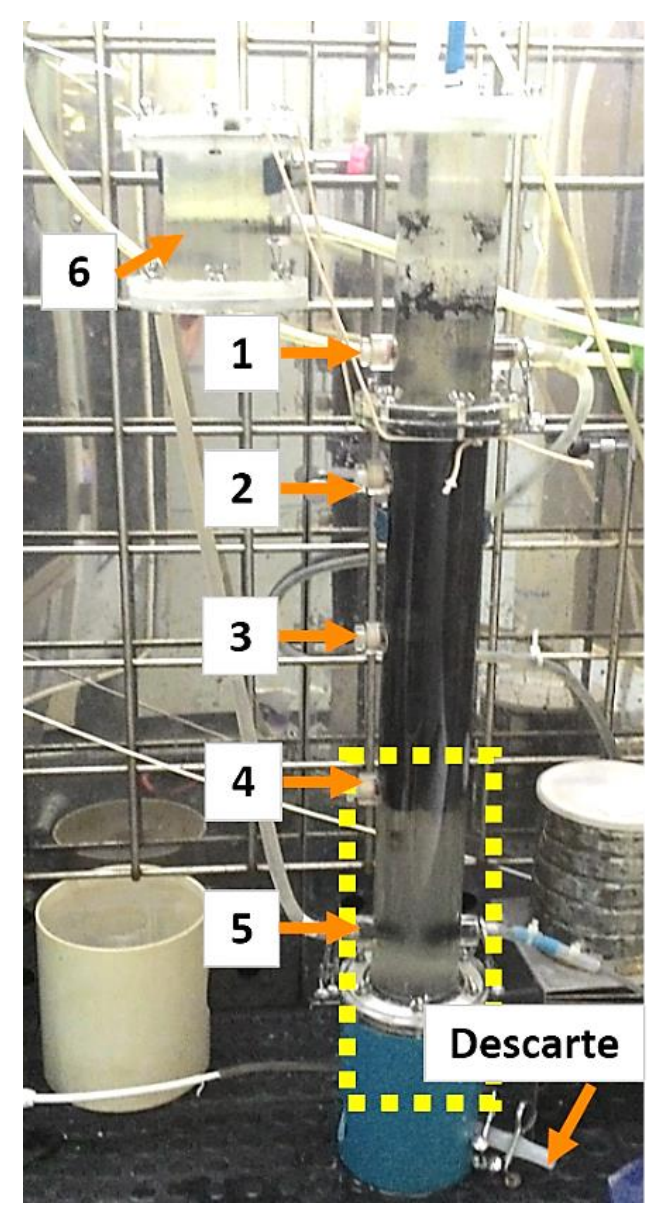

Figura 4.4: Reator DFSBR em operação com indicação dos pontos de coleta de amostra. Detalhe para a zona de sedimentação sem material suporte.

Fonte: $\mathrm{O}$ autor. 


\subsection{Inoculação}

A inoculação do reator foi realizada com biomassa proveniente de lodo de reator UASB (35 gSTV.L ${ }^{-1}$ ) tratando efluente de abatedouro de aves (Abatedouro Ideal, Pereiras/SP - Brasil), durante a primeira etapa (ETAPA 1), operada com meio sintético. Durante as etapas posteriores (ETAPAS 2 e 3), operadas com vinhaça real, foi empregada uma mistura (1:1) de dois lodos granulares: O primeiro proveniente do mesmo reator UASB tratando efluente de avícola (IN-1), como anteriormente indicado, e o segundo proveniente de reator UASB em escala piloto para tratamento de vinhaça em condição mesofílica (IN-2) (29 gSTV.L ${ }^{-1}$ ) (ALVES, 2018 - trabalho de doutorado em andamento) ${ }^{1}$.

O protocolo de inoculação aplicado ao início das 3 ETAPAS consistiu de uma adaptação da metodologia proposta por ZAIAT et al. (1994). O lodo granular foi desagregado em liquidificador. O reator montado e com o material suporte acondicionado no leito foi preenchido com uma mistura concentrada do inóculo com o efluente orgânico a ser utilizado (proporção de 1:5 e $\mathrm{pH}=7,0$ ) permanecendo em repouso durante um período de 24 horas. Após esse tempo, $5 \mathrm{~L}$ de efluente orgânico recém preparado $(\mathrm{pH}=7,0)$ foram mantidos em recirculação fechada do sistema por 7 dias consecutivos, tendo sido aplicada uma DQO inicial da ordem de $2000 \mathrm{mg} . \mathrm{L}^{-1}$ e relação $\mathrm{DQO} / \mathrm{SO}_{4}{ }^{2-}$ próxima a 1,0 , de forma a proporcionar uma pressão de seleção favorável às BRS. Em seguida o reator passou a ser alimentado de modo contínuo, com concentrações afluentes de DQO crescentes, até $4000 \mathrm{mgDQO} . \mathrm{L}^{-1}$ e relação $\mathrm{DQO} / \mathrm{SO}_{4}{ }^{2-}$ próxima de 2,0.

\footnotetext{
${ }^{1}$ ALVES, I. Estudo da manta de lodo e do efeito das taxas de recirculação e das cargas orgânicas em reatores UASB para produção de metano no processamento da vinhaça de cana-de-açúcar. Tese (Doutorado). Trabalho em andamento pelo Programa de Pós Graduação em Engenharia Hidráulica e Saneamento da Escola de Engenharia de São Carlos (EESC/USP).
} 


\section{5 Água Residuária}

\subsection{1 Água residuária sintética (ETAPA 1)}

Conforme mencionado anteriormente (subseção 4.1.1, p. 60), durante a primeira etapa de operação do reator DFSBR (ETAPA 1) foi testada uma mistura de DAM sintética com um efluente orgânico sintético simulando a fração solúvel da vinhaça. Esse efluente orgânico sintético foi elaborado conforme as diversas caracterizações de diferentes vinhaças realizadas no Laboratório de Processos Biológicos (LPB/EESC/USP) e reportadas por ROCHA (2012), ALVES (2015), LONGO (2015) e FUESS (2017).

A vinhaça sintética era diluída com água de abastecimento (proporção 1:5) para obtenção de uma concentração de DQO afluente da ordem de $4000 \mathrm{mg} . \mathrm{L}^{-1}$ e recebia dosagem adicional de sulfato de sódio $\left(3 \mathrm{~g} \mathrm{Na}_{2} \mathrm{SO}_{4} \cdot \mathrm{L}^{-1}\right)$ para simular uma concentração de sulfato da ordem de $2000 \mathrm{mgSO}_{4}{ }^{2-} \cdot \mathrm{L}^{-1}$, o qual seria proveniente da adição de uma drenagem ácida de minas com elevado teor de sulfato (MELLO et al., 2014). A relação DQO/SO ${ }_{4}{ }^{2-}$ foi mantida próxima de 2,0 durante todo o período experimental. O meio sintético orgânico era preparado três vezes por semana e armazenado em geladeira $\left(4^{\circ} \mathrm{C}\right)$ para manutenção de suas características originais.

A Tabela 4.2 apresenta as dosagens empregadas das diversas soluções estoque ou a dosagem direta dos reagentes sólidos que foram utilizados no preparo do efluente orgânico sintético (vinhaça sintética). 
Tabela 4.2: Composições das soluções estoque e dosagem dos diversos componentes utilizados no preparo da vinhaça sintética.

\begin{tabular}{|c|c|c|c|}
\hline Componentes & & $\begin{array}{l}\text { Solução } \\
\text { estoque }\left(g . L^{-1}\right)\end{array}$ & $\begin{array}{l}\text { Dosagem } \\
(\text { por g de DQO)* }\end{array}$ \\
\hline \multirow{6}{*}{$\begin{array}{l}\text { Substratos } \\
\text { Orgânicos }\end{array}$} & Sacarose $\left(\mathrm{C}_{12} \mathrm{H}_{22} \mathrm{O}_{11}\right)$ & - & $0,526 \mathrm{~g}$ \\
\hline & Etanol $\left(\mathrm{CH}_{3} \mathrm{CH}_{2} \mathrm{OH}\right)$ & - & $0,185 \mathrm{~mL}$ \\
\hline & Ácido acético $\left(\mathrm{CH}_{3} \mathrm{COOH}\right)$ & - & $0,082 \mathrm{~mL}$ \\
\hline & Ácido propiônico $\left(\mathrm{C}_{2} \mathrm{H}_{5} \mathrm{COOH}\right)$ & - & $0,028 \mathrm{~mL}$ \\
\hline & Ácido butírico $\left(\mathrm{C}_{3} \mathrm{H}_{7} \mathrm{COOH}\right)$ & - & $0,036 \mathrm{~mL}$ \\
\hline & Fenol $\left(\mathrm{C}_{6} \mathrm{H}_{5} \mathrm{OH}\right)$ & 6,5 & $0,052 \mathrm{~mL}$ \\
\hline \multirow{7}{*}{$\begin{array}{l}\text { Solução de } \\
\text { Metais }\end{array}$} & Cloreto férrico hexahidratado $\left(\mathrm{FeCl}_{3} \cdot 6 \mathrm{H}_{2} \mathrm{O}\right)$ & 7,56 & \multirow{7}{*}{$0,3 \mathrm{~mL}$} \\
\hline & $\begin{array}{l}\text { Cloreto de manganês tetrahidratado } \\
\left(\mathrm{MnCl}_{2} \cdot 4 \mathrm{H}_{2} \mathrm{O}\right)\end{array}$ & 1,55 & \\
\hline & Cloreto de zinco $\left(\mathrm{ZnCl}_{2}\right)$ & 0,14 & \\
\hline & Cloreto de cobre diidratado $\left(\mathrm{CuCl}_{2} \cdot 2 \mathrm{H}_{2} \mathrm{O}\right)$ & 0,13 & \\
\hline & $\begin{array}{l}\text { Cloreto de níquel hexahidratado } \\
\left(\mathrm{NiCl}_{2} \cdot 6 \mathrm{H}_{2} \mathrm{O}\right)\end{array}$ & 0,11 & \\
\hline & Cloreto de chumbo $\left(\mathrm{PbCl}_{2}\right)$ & 0,06 & \\
\hline & Cloreto de cádmio hidratado $\left(\mathrm{CdCl}_{2} \cdot \mathrm{H}_{2} \mathrm{O}\right)$ & 0,02 & \\
\hline \multirow{3}{*}{$\begin{array}{l}\text { Solução de } \\
\text { Sais }\end{array}$} & Cloreto de cálcio diidratado $\left(\mathrm{CaCl}_{2} \cdot 2 \mathrm{H}_{2} \mathrm{O}\right)$ & 61,14 & \multirow{3}{*}{$1,2 \mathrm{~mL}$} \\
\hline & Cloreto de sódio $(\mathrm{NaCl})$ & 41,41 & \\
\hline & $\begin{array}{l}\text { Cloreto de magnésio hexahidratado } \\
\left(\mathrm{MgCl}_{2} \cdot 6 \mathrm{H}_{2} \mathrm{O}\right)\end{array}$ & 84,02 & \\
\hline \multirow{2}{*}{ Macronutrientes } & Cloreto de amônio $\left(\mathrm{NH}_{4} \mathrm{Cl}\right)$ & 175,70 & \multirow{2}{*}{$0,9 \mathrm{~mL}$} \\
\hline & Fosfato de potássio monobásico $\left(\mathrm{KH}_{2} \mathrm{PO}_{4}\right)$ & 15,81 & \\
\hline Fonte de potássio & Cloreto de potássio $(\mathrm{KCl})$ & - & $0,213 \mathrm{~g}$ \\
\hline Fonte de sulfato & Sulfato de sódio $\left(\mathrm{Na}_{2} \mathrm{SO}_{4}\right)$ & - & $0,450 \mathrm{~g}^{* *}$ \\
\hline
\end{tabular}

*A dosagem de cada reagente é função do volume final de meio sintético e da concentração de DQO pretendida. Por exemplo, para preparar $1 \mathrm{~L}$ de meio sintético contendo 4 gDQO.L ${ }^{-1}$, multiplicar a quantidade de cada reagente pela massa final de DQO exigida (1 L x 4 gDQO. $\left.\mathrm{L}^{-1}=4 \mathrm{gDQO}\right)$.

**Simulando apenas o sulfato presente na vinhaça. Durante o presente estudo o meio sintético era posteriormente enriquecido com sulfato, simulando a introdução de uma DAM.

Fonte: GODOI et al., 2017a.

O efluente orgânico sintético também era enriquecido com vitaminas (TOUZEL; ALBAGNAC, 1983) e micronutrientes (TORRES, 1992) (Tabela 4.3) os quais, embora não tenham sido quantificados nas caracterizações da vinhaça, são importantes para o estabelecimento dos processos anaeróbios (SPEECE, 1983). 
Tabela 4.3: Soluções estoque de vitaminas e micronutrientes utilizadas na suplementação do substrato sintético.

\begin{tabular}{|c|c|c|c|}
\hline Componentes & & $\begin{array}{l}\text { Solução } \\
\text { estoque }\left(\mathrm{g} . \mathrm{L}^{-1}\right)\end{array}$ & $\begin{array}{l}\text { Dosagem } \\
\left(\mathrm{mL} . \mathrm{L}^{-1}\right)\end{array}$ \\
\hline \multirow[t]{4}{*}{ Micronutrientes $^{(1)}$} & Cloreto de cobalto hexahidratado $\left(\mathrm{CoCl}_{2} \cdot 6 \mathrm{H}_{2} \mathrm{O}\right)$ & 0,096 & \multirow{4}{*}{0,5} \\
\hline & Ácido bórico $\left(\mathrm{H}_{3} \mathrm{BO}_{3}\right)$ & 0,040 & \\
\hline & Molibdato de sódio hidratado $\left(\mathrm{NaMoO}_{4} \cdot \mathrm{H}_{2} \mathrm{O}\right)$ & 0,096 & \\
\hline & $\begin{array}{l}\text { Selenito de sódio pentahidratado } \\
\left(\mathrm{Na}_{2} \mathrm{SeO}_{3} .5 \mathrm{H}_{2} \mathrm{O}\right)\end{array}$ & 0,104 & \\
\hline \multirow[t]{10}{*}{ Vitaminas $^{(2)}$} & Biotina $\left(\mathrm{C}_{10} \mathrm{H}_{16} \mathrm{~N}_{2} \mathrm{O}_{3} \mathrm{~S}\right)$ & 0,002 & \multirow{10}{*}{1,0} \\
\hline & Ácido fólico $\left(\mathrm{C}_{10} \mathrm{H}_{16} \mathrm{~N}_{2} \mathrm{O}_{3} \mathrm{~S}\right)$ & 0,002 & \\
\hline & Tiamina $\left(\mathrm{C}_{12} \mathrm{H}_{17} \mathrm{~N}_{4} \mathrm{OS}\right)$ & 0,005 & \\
\hline & Riboflavina $\left(\mathrm{C}_{17} \mathrm{H}_{20} \mathrm{~N}_{4} \mathrm{O}_{6}\right)$ & 0,005 & \\
\hline & Ácido nicotínico (Niacina) $\left(\mathrm{C}_{6} \mathrm{H}_{5} \mathrm{NO}_{2}\right)$ & 0,005 & \\
\hline & Pantotenato de cálcio $\left(\mathrm{C}_{18} \mathrm{H}_{32} \mathrm{CaN}_{2} \mathrm{O}_{10}\right)$ & 0,005 & \\
\hline & Piridoxina $\left(\mathrm{C}_{8} \mathrm{H}_{12} \mathrm{ClNO}_{3}\right)$ & 0,01 & \\
\hline & Cobalamina $\left(\mathrm{C}_{63} \mathrm{H}_{88} \mathrm{CoN}_{14} \mathrm{O}_{14} \mathrm{P}\right)$ & 0,0001 & \\
\hline & Ácido lipóico $\left(\mathrm{C}_{8} \mathrm{H}_{14} \mathrm{O}_{2} \mathrm{~S}_{2}\right)$ & 0,005 & \\
\hline & Ácido p-aminobenzóico $\left(\mathrm{NH}_{2} \mathrm{C}_{6} \mathrm{H}_{4} \mathrm{COOH}\right)$ & 0,005 & \\
\hline
\end{tabular}

Fonte: ${ }^{(1)}$ TORRES, 1992; ${ }^{(2)}$ TOUZEL; ALBAGNAC, 1983.

Ainda que as bactérias redutoras de sulfato já tenham sido observadas atuando em faixas de pH mais baixas (SÁNCHEZ-ANDREA et al., 2014), o pH do meio sintético orgânico foi ajustado para próximo de 6,0 por meio de dosagem de uma solução de hidróxido de sódio $(\mathrm{NaOH} 12 \mathrm{M})$. Este procedimento teve como objetivo acelerar a partida do sistema assim como possibilitar o estabelecimento e a manutenção da metanogênese concomitantemente à sulfetogênese.

Para simular as concentrações de ferro provenientes da drenagem ácida de minas a serem aplicadas em cada fase operacional (Tabela 4.1), o meio sintético orgânico recebia dosagem adequada de uma solução concentrada de cloreto ferroso tetrahidratado $\left(\mathrm{FeCl}_{2} \cdot 4 \mathrm{H}_{2} \mathrm{O}\right)$ diretamente na tubulação de entrada do reator. A concentração da solução de $\mathrm{FeCl}_{2} .4 \mathrm{H}_{2} \mathrm{O}$ foi variada durante as fases operacionais, de acordo com as concentrações de ferro desejadas no afluente. 
Para evitar a oxidação do ferro II a ferro III (insolúvel) e a sua precipitação no reservatório afluente, a solução de $\mathrm{FeCl}_{2} \cdot 4 \mathrm{H}_{2} \mathrm{O}$ era preparada com água deionizada e mantida sob fluxo de nitrogênio $\left(\mathrm{N}_{2}\right)$ durante 15 min para remoção do oxigênio dissolvido. $\mathrm{O}$ pH da solução era ajustado para próximo de 2,0 com dosagem de uma solução 1:1 de ácido clorídrico $(\mathrm{HCl} 6 \mathrm{M})$. A vazão de entrada no reator da solução de cloreto ferroso (DAM sintética) foi da ordem de $0,05 \mathrm{~mL} \cdot \mathrm{min}^{-1}$, a qual foi escolhida para se evitar a acidificação do meio sintético pelo baixo $\mathrm{pH}$ da solução estoque de ferro e também para não modificar o TDH imposto ao reator (vazão da solução de ferro menor que $10 \%$ da vazão de alimentação).

A Tabela 4.4 apresenta a composição final do meio sintético utilizado na alimentação do reator DFSBR durante a ETAPA 1 de operação.

Tabela 4.4: Composição final do efluente sintético utilizado durante a ETAPA 1 simulando a mistura de vinhaça com DAM rica em ferro.

\begin{tabular}{|c|c|c|}
\hline \multicolumn{2}{|l|}{ Constituintes } & \multirow{2}{*}{$\begin{array}{l}\text { Concentrações } \\
4000\end{array}$} \\
\hline Matéria orgânica & DQO solúvel $\left(\mathrm{mg} \mathrm{O}_{2} \cdot \mathrm{L}^{-1}\right)$ & \\
\hline & Sacarose $\left(\mathrm{mg} . \mathrm{L}^{-1}\right)$ & 2100 \\
\hline & Etanol (mg.L $\left.\mathrm{L}^{-1}\right)$ & 582 \\
\hline & Ácido acético $\left(\mathrm{mg} \cdot \mathrm{L}^{-1}\right)$ & 345 \\
\hline & Ácido propiônico $\left(\mathrm{mg} \cdot \mathrm{L}^{-1}\right)$ & 111 \\
\hline & Ácido butírico (mg.L $\left.\mathrm{L}^{-1}\right)$ & 140 \\
\hline & Fenol $\left(\mathrm{mg} . \mathrm{L}^{-1}\right)$ & 1,5 \\
\hline \multirow[t]{3}{*}{ Nutrientes } & Sulfato $\left(\mathrm{mg} \mathrm{SO}_{4} \cdot \mathrm{L}^{-1}\right)$ & $2000^{*}$ \\
\hline & Nitrogênio total (mg NTK.L $\left.{ }^{-1}\right)$ & 165,5 \\
\hline & Fósforo $\left(\mathrm{mg} \mathrm{PO}_{4}{ }^{3+} \cdot \mathrm{L}^{-1}\right)$ & 39,5 \\
\hline \multirow[t]{11}{*}{ Metais } & Potássio (mg K.L $L^{-1}$ ) & 453,5 \\
\hline & Cálcio (mg Ca.L $\mathrm{L}^{-1}$ ) & 80,0 \\
\hline & Sódio (mg Na.L ${ }^{-1}$ ) & 135,7 \\
\hline & Magnésio (mg Mg.L ${ }^{-1}$ ) & 48,2 \\
\hline & Manganês (mg Mn.L $\mathrm{L}^{-1}$ ) & 0,52 \\
\hline & Zinco (mg Zn.L $\left.\mathrm{L}^{-1}\right)$ & 0,08 \\
\hline & Cobre $\left(\mathrm{mg} \mathrm{Cu} . \mathrm{L}^{-1}\right)$ & 0,06 \\
\hline & Chumbo (mg Pb.L $\mathrm{L}^{-1}$ ) & 0,06 \\
\hline & Níquel (mg Ni.L ${ }^{-1}$ ) & 0,03 \\
\hline & Cádmio (mg Cd.L $\left.\mathrm{L}^{-1}\right)$ & 0,01 \\
\hline & Ferro (mg Fe.L $\left.\mathrm{L}^{-1}\right)$ & Variável $(2,0-400)^{*}$ \\
\hline
\end{tabular}

*Concentrações advindas da DAM sintética.

Fonte: GODOI et al., 2017a. 


\subsubsection{Vinhaça de cana-de-açúcar (ETAPAS 2 e 3)}

Durante as etapas subsequentes do estudo (ETAPAS 2 e 3) utilizou-se vinhaça proveniente da Usina Rio Pardo (Cerqueira César, SP, Brasil), com alta concentração de matéria orgânica $\left(\approx 120\right.$ gDQO. $\left.\mathrm{L}^{-1}\right)$. A vinhaça utilizada é concentrada em aparelhos evaporadores com o objetivo de minimizar o seu volume, facilitando assim o transporte desse resíduo até os canaviais, situados em zona distante da Usina, onde é então disposto no solo, durante o processo de fertirrigação. Outra vantagem da concentração da vinhaça é a reutilização, no processo produtivo, da água recuperada a partir da evaporação (MUTTON et al., 2014).

No presente estudo, a vinhaça concentrada foi escolhida para favorecer a viabilidade do tratamento in loco de uma drenagem ácida real, de forma que seria requerido o transporte de menores volumes de vinhaça.

A vinhaça concentrada era mantida em reservatório para a sedimentação dos sólidos em suspensão e o sobrenadante era diluído em água de abastecimento para obtenção de DQO afluente próxima de $4000 \mathrm{mg} \cdot \mathrm{L}^{-1}$. $\mathrm{Na}_{2} \mathrm{SO}_{4}$ era dosado para complementar o conteúdo de sulfato da vinhaça diluída $\left(\approx 800 \mathrm{mg} . \mathrm{L}^{-1}\right)$ e atingir uma concentração afluente da ordem de $2000 \mathrm{mgSO}_{4} \cdot \mathrm{L}^{-1}$, visando a manutenção da relação $\mathrm{DQO} / \mathrm{SO}_{4}{ }^{2-}$ igual a 2,0 , a qual foi utilizada durante a etapa anterior com meio sintético. Assim, considerou-se o tratamento de uma DAM com concentração de sulfato da ordem de $1200 \mathrm{mg} \cdot \mathrm{L}^{-1}$.

A vinhaça diluída era preparada três vezes por semana e mantida em refrigerador $\left(4^{\circ} \mathrm{C}\right)$ para manutenção de suas características. A suplementação nutricional utilizada durante a ETAPA 1 (vinhaça sintética) foi suprimida, de forma que a vinhaça de cana-de-açúcar também passou a ser dosada como fonte exclusiva de vitaminas e nutrientes para o processo. 
O pH da vinhaça diluída era ajustado em 6,0 (ETAPA 2) ou em valores inferiores (ETAPA 3) pela dosagem de soluções concentradas de $\mathrm{NaOH}(12 \mathrm{M})$ ou $\mathrm{HCl}(6 \mathrm{M})$.

A Tabela 4.5 apresenta a composição da vinhaça concentrada que foi utilizada no presente estudo.

Tabela 4.5: Composição original da vinhaça concentrada utilizada durante as ETAPAS 2 e 3 do presente estudo (após adequada diluição).

\begin{tabular}{|c|c|c|}
\hline \multicolumn{2}{|l|}{ Constituintes } & \multirow{2}{*}{$\frac{\text { Concentrações }}{120000}$} \\
\hline Matéria orgânica $^{(1)}$ & DQO bruta $\left(\mathrm{mg} \mathrm{O}_{2} \cdot \mathrm{L}^{-1}\right)$ & \\
\hline & DBO bruta $\left(\mathrm{mg} \mathrm{O}_{2} \cdot \mathrm{L}^{-1}\right)$ & 60600 \\
\hline & Carboidratos solúveis $\left(\mathrm{mg} \cdot \mathrm{L}^{-1}\right)$ & 17200 \\
\hline & Ácidos voláteis totais $\left(\mathrm{mg} \mathrm{CH}_{3} \mathrm{COOH} . \mathrm{L}^{-1}\right)$ & 9500 \\
\hline & Fenóis totais $\left(\mathrm{mg} \cdot \mathrm{L}^{-1}\right)$ & 12 \\
\hline \multirow[t]{4}{*}{ Nutrientes ${ }^{(2)}$} & Sulfato $\left(\mathrm{mg} \mathrm{SO}_{4} \cdot \mathrm{L}^{-1}\right)$ & $25200 *$ \\
\hline & Nitrogênio total (mg NTK.L $\left.\mathrm{L}^{-1}\right)$ & 3100 \\
\hline & Nitrogênio amoniacal $\left(\mathrm{mg} \mathrm{NH}_{4} \cdot \mathrm{L}^{-1}\right)$ & 400 \\
\hline & Fósforo $\left(\mathrm{mg} \mathrm{PO}_{4}{ }^{3+} . \mathrm{L}^{-1}\right)$ & 860 \\
\hline \multirow[t]{11}{*}{ Metais ${ }^{(2)}$} & Potássio (mg K.L $\left.{ }^{-1}\right)$ & 4000 \\
\hline & Cálcio (mg Ca.L ${ }^{-1}$ ) & 2200 \\
\hline & Sódio (mg Na.L $\left.\mathrm{L}^{-1}\right)$ & 6000 \\
\hline & Magnésio (mg Mg.L ${ }^{-1}$ ) & 920 \\
\hline & Manganês (mg Mn.L $\mathrm{L}^{-1}$ ) & 10,2 \\
\hline & Zinco (mg Zn.L $\left.{ }^{-1}\right)$ & 1,2 \\
\hline & Cobre (mg Cu. $\left.\mathrm{L}^{-1}\right)$ & 1,1 \\
\hline & Chumbo (mg Pb. $\mathrm{L}^{-1}$ ) & 1,0 \\
\hline & Níquel (mg Ni.L $\left.{ }^{-1}\right)$ & 0,6 \\
\hline & Cádmio (mg Cd.L $\left.\mathrm{L}^{-1}\right)$ & 0,2 \\
\hline & Ferro $\left(\mathrm{mg} \mathrm{Fe} . \mathrm{L}^{-1}\right)$ & $40 *$ \\
\hline \multirow[t]{6}{*}{ Sólidos ${ }^{(2)}$} & Sólidos totais $\left(\mathrm{g} \cdot \mathrm{L}^{-1}\right)$ & 103 \\
\hline & Sólidos totais voláteis $\left(\mathrm{g} \cdot \mathrm{L}^{-1}\right)$ & 71 \\
\hline & Sólidos suspensos totais $\left(\mathrm{g} \cdot \mathrm{L}^{-1}\right)$ & 20 \\
\hline & Sólidos suspensos voláteis $\left(\mathrm{g} . \mathrm{L}^{-1}\right)$ & 18 \\
\hline & Sólidos dissolvidos totais $\left(\mathrm{g} . \mathrm{L}^{-1}\right)$ & 83 \\
\hline & Sólidos dissolvidos voláteis $\left(\mathrm{g} . \mathrm{L}^{-1}\right)$ & 53 \\
\hline
\end{tabular}

*Concentrações advindas da própria vinhaça, previamente à diluição e mistura da DAM sintética.

Fonte: ${ }^{(1)} \mathrm{O}$ autor; ${ }^{(2)}$ ALVES (2015) e LONGO (2015). 
Manteve-se a aplicação da solução concentrada de $\mathrm{FeCl}_{2} \cdot 4 \mathrm{H}_{2} \mathrm{O}$ (DAM sintética) preparada conforme procedimento já apresentado no item anterior (subseção 4.5.1, p. 69). A vazão dessa solução foi mantida próxima de $0,05 \mathrm{~mL} \cdot \mathrm{min}^{-1}$ e a concentração de ferro na solução concentrada foi ajustada para atender às concentração afluentes requeridas.

\subsection{Análises Físico-Químicas}

Determinações analíticas de pH, DQO, alcalinidade, ácidos orgânicos voláteis, sulfato, sulfeto, ferro total e composição do biogás para o monitoramento do reator DFSBR foram realizadas de duas a três vezes por semana, conforme as metodologias apresentadas na Tabela 4.6. Com frequência quinzenal também foram realizadas análises da série de sólidos (totais, suspensos, fixos e voláteis) do efluente do reator e do descarte de lodo da câmara inferior de sedimentação, bem como análises da composição elementar desse descarte.

Tabela 4.6: Metodologias utilizadas nas determinações analíticas.

\begin{tabular}{lll}
\hline Análises & Metodologias & Referências \\
\hline pH & Método potenciométrico (Eletrodo de pH) & APHA/AWWA/WEF (2005) \\
DQO & Método colorimétrico em refluxo fechado & APHA/AWWA/WEF (2005) \\
\hline Alcalinidade & Método titulométrico & RIPLEY et al. (1986) \\
Ácidos voláteis totais & Método titulométrico & $\begin{array}{l}\text { DILALLO; ALBERTSON } \\
\text { (1961) }\end{array}$ \\
\hline Ácidos orgânicos & Cromatografia gasosa & ADORNO et al. (2014a) \\
\hline Sulfeto total & Método colorimétrico do azul de metileno & APHA/AWWA/WEF (2005) \\
Sulfato & Método turbidimétrico do cloreto de bário & APHA/AWWA/WEF (2005) \\
Ferro total & Método colorimétrico da ferrozina & VIOLLIER et al. (2000) \\
\hline Sólidos & Método gravimétrico & APHA/AWWA/WEF (2005) \\
\hline Composição do biogás & Cromatografia gasosa & ADORNO et al. (2014b) \\
\hline $\begin{array}{l}\text { Caracterização do } \\
\text { precipitado }\end{array}$ & $\begin{array}{l}\text { Espectrometria de energia dispersiva de } \\
\text { raios-X (EDS/EDX) }\end{array}$ & - \\
\hline Font: O autor & &
\end{tabular}

Fonte: $\mathrm{O}$ autor. 
A vazão de biogás produzido foi monitorada diariamente com o auxílio de gasômetro on-line MilliGascounter MGC-1 (Dr.-Ing. Ritter Apparatebau GmbH \& Co. KG, Bochum, Alemanha) conectado à saída do selo hídrico acoplado ao headspace do reator.

As especificidades de algumas variáveis analisadas estão descritas com maior detalhamento nas subseções a seguir:

\subsection{1 $p H$}

Além do $\mathrm{pH}$ afluente e efluente, foi monitorado também o valor de $\mathrm{pH}$ interno do reator. Esse procedimento se deveu ao fato de, logo após a saída do efluente do reator, os gases dissolvidos, em especial $\mathrm{H}_{2} \mathrm{~S}$ e $\mathrm{CO}_{2}$, serem rapidamente liberados para a atmosfera (SPEECE, 1996). Esse comportamento implica no aumento do $\mathrm{pH}$ da fase líquida devido ao deslocamento do equilíbrio químico do bicarbonato $\left(\mathrm{HCO}_{3}{ }^{-}+\mathrm{H}^{+} \rightleftharpoons \mathrm{H}_{2} \mathrm{O}+\mathrm{CO}_{2}\right)$ e do sulfeto de hidrogênio ( $\mathrm{HS}^{-}+\mathrm{H}^{+} \rightleftharpoons \mathrm{H}_{2} \mathrm{~S}$ ), implicando no consumo de prótons ( $\mathrm{H}^{+}$) (GODOI et al., 2017b). Para contornar esse problema, amostras líquidas eram coletadas diretamente do interior da câmara de equalização de nível (ponto de coleta $n^{\circ} 6$ indicado na Figura 4.4) por meio de septo imerso, com auxílio de uma seringa. A amostra era então transferida para béquer de volume adequado e a leitura do $\mathrm{pH}$ prontamente efetuada.

\subsubsection{Demanda química de oxigênio (DQO) e sulfeto total dissolvido (STD)}

As análises de demanda química de oxigênio (DQO) foram realizadas em amostras do afluente e do efluente do reator. No caso do efluente, além das determinações de DQO bruta e filtrada (membrana com poro de 1,2 $\mu \mathrm{m}$ ), também foram preparadas amostras centrifugadas (3500 rpm durante 5 minutos) após adição de sulfato de zinco $\left(\mathrm{ZnSO}_{4}\right)$ em excesso. A análise 
desse sobrenadante tem por objetivo eliminar a interferência do sulfeto dissolvido na determinação da DQO através da sua precipitação sob a forma de sulfeto de zinco (ZnS). A diferença entre a DQO efluente filtrada $\left(\mathrm{DQO}_{\mathrm{FILTRADA}}{ }^{\mathrm{EF}}\right)$ e a DQO efluente centrifugada com sulfato de zinco $\left(\mathrm{DQO}_{\mathrm{ORGÂNICA}}{ }^{\mathrm{EF}}\right)$ corresponde à $\mathrm{DQO}$ devida ao sulfeto total dissolvido no

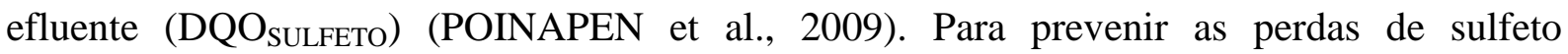
dissolvido por volatilização, as amostras coletadas para análise de DQO recebiam algumas gotas de solução concentrada de $\mathrm{NaOH}$ (12 M) (POINAPEN et al., 2009).

Para converter a concentração da DQO devida ao sulfeto em termos de sulfeto total dissolvido (STD) foi utilizado o fator empírico de conversão de 1,2 mgDQO.mgSTD ${ }^{-1}$, determinado por AQUINO et al. (2007). Este fator, menor que o estequiométrico ( 2 mgDQO.mgSTD ${ }^{-1}$ ), leva em conta as perdas sistemáticas de sulfeto por volatilização, principalmente sob as condições ácidas da digestão aplicada durante o teste da DQO. A Equação (4.2) apresenta o cálculo da concentração de sulfeto total dissolvido empregada.

$\mathrm{STD}=\frac{\left(\mathrm{DQO}_{\text {FILTRADA }}{ }^{\mathrm{EF}}-\mathrm{DQO}_{\left.\mathrm{ORGÂNICA}^{\mathrm{EF}}\right)}\right.}{1,2}$

Na qual STD é a concentração de sulfeto total dissolvido no efluente do reator $\left(\mathrm{mgS}^{2-} \cdot \mathrm{L}^{-1}\right) ; \mathrm{DQO}_{\mathrm{FILTRADA}}{ }^{\mathrm{EF}}$ é a concentração de DQO dissolvida no efluente $\left(\mathrm{mgO}_{2} \cdot \mathrm{L}^{-1}\right)$; e DQO $_{\text {ORGÂNICA }}{ }^{\mathrm{EF}}$ é a concentração de DQO dissolvida no efluente tendo sido removida a interferência devida ao sulfeto total dissolvido $\left(\mathrm{mgO}_{2} \cdot \mathrm{L}^{-1}\right)$.

Já para determinar a DQO efluente em suspensão utilizou-se o cálculo indicado na Equação (4.3). Nesse caso, descontou-se tanto a parcela de DQO orgânica dissolvida no efluente $\left(\mathrm{DQO}_{\mathrm{ORGANNICA}^{\mathrm{EF}}}\right.$ ) quanto a DQO devida ao sulfeto total no efluente (STE) da DQO bruta determinada no efluente do reator $\left(\mathrm{DQO}_{\mathrm{BRUTA}}{ }^{\mathrm{EF}}\right)$. A concentração de STE foi 
determinada conforme descrito a seguir, na subseção 4.6.3, p. 79. Empregou-se o mesmo fator de conversão acima mencionado (1,2 mgDQO.mgSTE $\left.{ }^{-1}\right)$ para converter a concentração de sulfetos totais em termos de DQO.

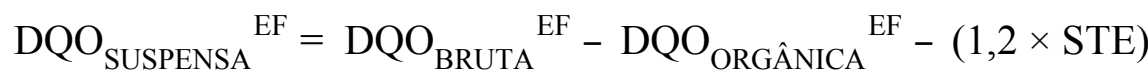

Na qual DQO SUSPENSA $^{\mathrm{EF}}$ é a concentração de DQO orgânica em suspensão no efluente do reator $\left(\mathrm{mgO}_{2} \cdot \mathrm{L}^{-1}\right)$; DQO $\mathrm{BRUTA}^{\mathrm{EF}}$ é a concentração de DQO bruta no efluente $\left(\mathrm{mgO}_{2} \cdot \mathrm{L}^{-1}\right)$; e STE é a concentração de sulfeto total no efluente $\left(\mathrm{mgS}^{2-} \cdot \mathrm{L}^{-1}\right)$.

A DQO SUSPENSA $^{\text {EF }}$ foi utilizada como medida indireta de sólidos suspensos voláteis (SSV) no efluente do reator, podendo ser convertida em termos de concentração de SSV aplicando o fator de 1,42 mgDQO.mgSSV${ }^{-1}$ (SPEECE, 1996), conforme indicado na Equação (4.4).

$\mathrm{SSV}_{\text {EFLUENTE }}=\frac{\mathrm{DQO}_{\text {SUSPENSA }^{\mathrm{EF}}}}{1,42}$

Na qual SSV EFLUENTE é a concentração de sólidos suspensos voláteis estimada no efluente do reator (mgSSV.L $\left.{ }^{-1}\right)$.

No caso das amostras afluentes, considerou-se a DQO total medida na entrada do reator $\left(\mathrm{DQO}_{\mathrm{AFLUENTE}}\right)$ como sendo predominantemente dissolvida. De fato, durante a ETAPA 1, operada exclusivamente com efluentes sintéticos, todos os componentes orgânicos eram de caráter solúvel. Já durante as ETAPAS 2 e 3, a vinhaça real diluída, após longo tempo de sedimentação no tanque de armazenamento, apresentava uma fração de DQO suspensa da ordem de 5\% da DQO total medida no afluente do reator, sendo, portanto, considerada desprezível. 


\subsubsection{Sulfeto total no efluente (STE)}

A concentração de sulfeto total no efluente (STE) é considerada como sendo composta pelas concentrações das diversas espécies de sulfeto de hidrogênio dissolvidas no meio líquido $\left(\mathrm{H}_{2} \mathrm{~S}, \mathrm{HS}^{-}\right.$e $\left.\mathrm{S}^{2-}\right)$ mais os sulfetos metálicos em suspensão (APHA/AWWA/WEF, 2005). Para determinação do STE, uma amostra de $0,2 \mathrm{~mL}$ do efluente retirado diretamente da zona de saída do reator (equalizador de nível) era imediatamente fixada em $1 \mathrm{~mL}$ de solução 0,5 M de acetato de zinco e recebia 2 gotas de solução $12 \mathrm{M}$ de hidróxido de sódio $(\mathrm{NaOH})$ para elevação do pH (POINAPEN et al., 2009). Esse procedimento também foi realizado com o objetivo de se evitarem perdas de sulfeto por volatilização. Em seguida a amostra era submetida à análise colorimétrica do azul de metileno (APHA/AWWA/WEF, 2005).

\subsubsection{Sulfato dissolvido}

As amostras do efluente a serem analisadas quanto ao sulfato eram coletadas diretamente da câmara de saída do reator (equalizador de nível), filtradas em membrana de 1,2 $\mu \mathrm{m}$ e acidificadas com dosagem de algumas gotas de $\mathrm{HCl}$ concentrado (6 M). Em seguida, as amostras eram mantidas sob agitação durante alguns minutos para eliminação do sulfeto dissolvido, evitando assim a sua reoxidação a sulfato pelo oxigênio atmosférico. $10 \mathrm{~mL}$ das amostras (já diluídas em água deionizada, se necessário) eram submetidas ao teste turbidimétrico com cloreto de bário, conforme reportado pelo Standard Methods for the Examination of Water and Wastewater (APHA/AWWA/WEF, 2005). 


\subsubsection{Ferro total}

As análises das concentrações de ferro total no afluente e no efluente do reator foram realizadas conforme a metodologia apresentada por VIOLLIER et al. (2000). O método adotado baseia-se na utilização do reagente ferrozina (3-(2-Pyridyl)-5,6-diphenyl-1,2,4triazine-pp-disulfonic acid monosodium salt hydrate) o qual reage com o íon $\mathrm{Fe}^{2+}$ formando um complexo magenta estável, passível de ser analisado em espectrofotômetro empregandose absorção de $562 \mathrm{~nm}$ (VIOLLIER et al., 2000).

Previamente à análise, as amostras efluentes coletadas no reator eram submetidas ao protocolo de extração proposto por GARCÍA-BALBOA et al. (2011). Esse procedimento consistiu na adição de $1 \mathrm{~mL}$ de solução $1 \mathrm{M}$ de ácido clorídrico $(\mathrm{HCl})$ a cada $1 \mathrm{~mL}$ da amostra para a estabilização do ferro ferroso $\left(\mathrm{Fe}^{2+}\right)$ em solução e para a solubilização do ferro férrico $\left(\mathrm{Fe}^{3+}\right)$ pelo abaixamento do $\mathrm{pH}$ da fase líquida. Em seguida as amostras eram mantidas durante $24 \mathrm{~h}$ ao abrigo da luz.

Após 24 h de espera, $4 \mathrm{~mL}$ da amostra acidificada e diluída recebiam adição de 0,4 mL de solução $10^{-2} \mathrm{M}$ de ferrozina (preparada em solução $10^{-1} \mathrm{M}$ de acetato de amônio). Para reduzir todo o $\mathrm{Fe}^{3+}$ eventualmente presente novamente a $\mathrm{Fe}^{2+}$, única forma passível de reagir com a ferrozina, as amostras recebiam a adição de $0,6 \mathrm{~mL}$ de uma solução redutora (cloridrato de hidroxilamina 1,4 M preparada em $\mathrm{HCl} 2 \mathrm{M}$ ) e $0,2 \mathrm{~mL}$ de solução tampão (acetato de amônio 2 M com pH ajustado para próximo de 9,0 com hidróxido de amônio) (VIOLLIER et al., 2000). Após 10 minutos de reação as amostras eram lidas em 562 nm. Para eliminar a interferência da cor ou turbidez, preparava-se um branco com o próprio efluente acidificado e substituindo-se a adição da ferrozina por $0,4 \mathrm{~mL}$ de água deionizada.

No preparo da curva de calibração foi utilizado cloreto ferroso tetrahidratado $\left(\mathrm{FeCl}_{2} \cdot 4 \mathrm{H}_{2} \mathrm{O}\right)$ de grau analítico (P.A.). Uma solução estoque de $100 \mathrm{mgFe}{ }^{2+} \cdot \mathrm{L}^{-1}$ foi preparada 
em água ultrapura (Milli- $\mathrm{Q}^{\circledR}$ ) com pH ajustado para menos de 2,0 por dosagem de $\mathrm{HCl}$ concentrado. Os padrões foram preparados por diluição da solução estoque em água ultrapura para a obtenção de triplicatas com as seguintes concentrações de ferro: 1,0; 2,5; 5,0; 7,5; 10,0; 12,5 e 15,0 mg. $\mathrm{L}^{-1}$. A curva final de calibração, a equação ajustada e o coeficiente de correlação $\left(\mathrm{R}^{2}\right)$ estão apresentados na Figura 4.5.

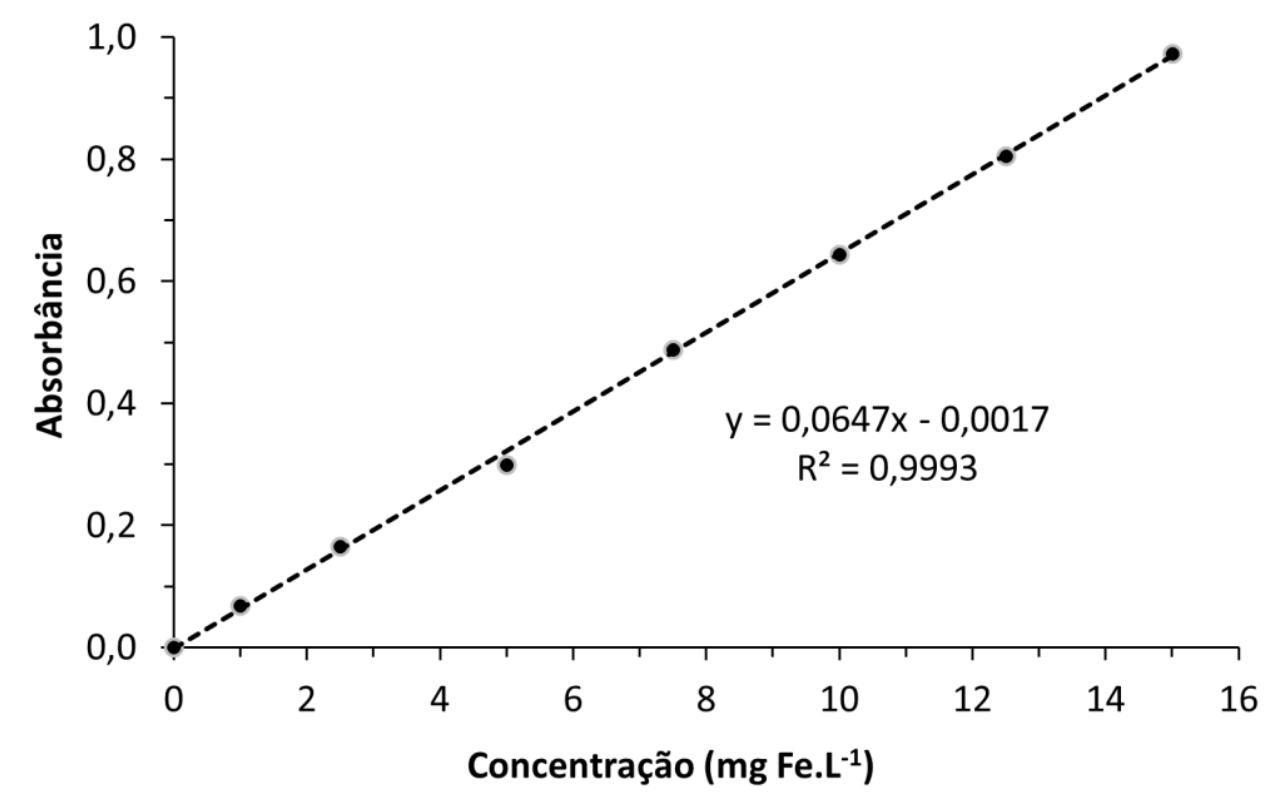

Figura 4.5: Curva de calibração estabelecida para a análise espectrofotométrica de ferro total pelo método da Ferrozina.

Fonte: $\mathrm{O}$ autor.

\subsubsection{Composição elementar do precipitado}

Amostras do lodo acumulado no cone inferior do reator foram coletadas a cada 30 dias para a realização de análises de EDX (espectrometria de energia dispersiva de raios-x) com o intuito de verificar as proporções de ferro $(\mathrm{Fe})$, enxofre $(\mathrm{S})$ e outros elementos no precipitado. Foi utilizado um equipamento EDX LINK ANALYTICAL (Isis System Series 200) acoplado 
a um microscópio de varredura eletrônica LEO440 (LEO Electron Microscopy Ltd., Cambridge, UK) com aumento de 500x.

Previamente às determinações, as amostras eram utilizadas para a quantificação de sólidos totais fixos (STF) e voláteis (STV) pelo método gravimétrico (APHA/AWWA/WEF, 2005). O resíduo das determinações de sólidos totais fixos (livres, portanto, de matéria orgânica) era encaminhado para o teste de EDX.

Amostras retiradas da superfície do material suporte também foram submetidas à análise de EDX ao longo das ETAPAS 2 e 3 para a determinação da proporção de ferro no biofilme.

A presente análise foi realizada com caráter essencialmente qualitativo, uma vez que seus resultados são dados em porcentagem do elemento por unidade de área, medida em triplicata. Os resultados obtidos não foram utilizados para fins de balanço de massa, mas para avaliar a possibilidade de recuperação dos metais nas condições proporcionadas pelo reator estudado.

\subsubsection{Composição dos ácidos orgânicos voláteis}

Para quantificação de ácidos orgânicos voláteis e álcoois no efluente do reator foi utilizado um cromatógrafo de gás GC-2010 (Shimadzu Scientific Instruments, Columbia, MD, USA) equipado com coluna HP-INNOWAX (30 m de comprimento x 0,25 mm de diâmetro interno x $0,25 \mu \mathrm{m}$ de espessura de filme) e detector de ionização em chama (FID), tendo hidrogênio como gás de arraste, segundo metodologia descrita por ADORNO et al. (2014a). 


\subsubsection{Composição do biogás}

A composição do biogás foi analisada em cromatógrafo gasoso GC-2014 (Shimadzu Scientific Instruments, Columbia, MD, USA), com detector de condutividade térmica (TCD) e coluna HP-PLOT/Q (30 m de comprimento x 0,53 mm de diâmetro interno x 40,0 $\mu \mathrm{m}$ de espessura de filme), tendo hidrogênio como gás de arraste, conforme metodologia apresentada por ADORNO et al. (2014b). O volume de amostra gasosa analisada foi de $1000 \mu \mathrm{L}$.

\subsection{Avaliação da alcalinidade devida a sulfeto}

Soluções padrões contendo bicarbonato de sódio $\left(\mathrm{NaHCO}_{3}\right)$ e sulfeto de hidrogênio dissolvido $\left(\mathrm{H}_{2} \mathrm{~S}_{(\mathrm{aq})}\right)$ foram preparadas com o objetivo de se avaliar a contribuição real do íon HS $^{-}$para com a alcalinidade total de reatores anaeróbios medida por procedimentos titulométricos. Sulfeto de hidrogênio dissolvido foi obtido a partir de uma solução concentrada de sulfeto de sódio nonahidratado $\left(\mathrm{Na}_{2} \mathrm{~S} .9 \mathrm{H}_{2} \mathrm{O}\right)$ com auxílio do aparato experimental mostrado na Figura 4.6. 


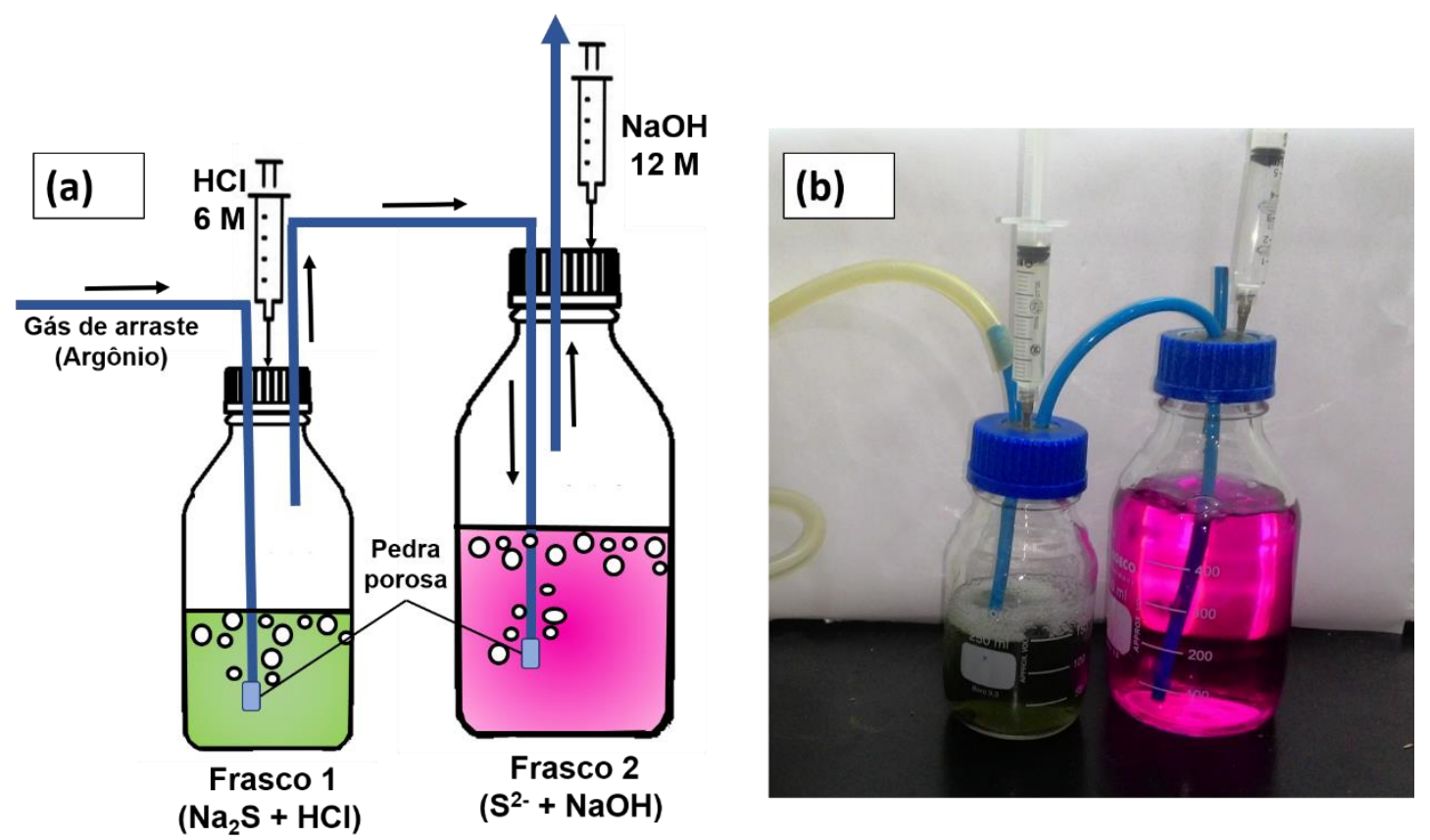

Figura 4.6: (a) Representação esquemática do aparato utilizado para a geração de sulfeto de hidrogênio dissolvido, e (b) fotografia ilustrativa do sistema em uso.

Fonte: GODOI et al., 2017b.

No primeiro frasco de vidro Duran ${ }^{\mathrm{TM}}$ foi preparada uma solução contendo cerca de $10 \mathrm{~g}$ de $\mathrm{Na}_{2} \mathrm{~S} .9 \mathrm{H}_{2} \mathrm{O}$ em $100 \mathrm{~mL}$ de água destilada. No segundo frasco Duran ${ }^{\mathrm{TM}}$ foram colocados $400 \mathrm{~mL}$ de água destilada com algumas gotas de solução indicadora de fenolftaleína e o pH foi elevado para acima de 12,0 com solução concentrada de $\mathrm{NaOH}$ (50\% $\mathrm{m} / \mathrm{v}$ ou $12 \mathrm{M})$. O headspace do primeiro frasco foi conectado por uma mangueira ao fundo do segundo frasco. Uma seringa foi utilizada para injetar $\mathrm{HCl}$ concentrado (6 M) diretamente na solução de sulfeto de sódio para a geração de sulfeto de hidrogênio $\left(\mathrm{H}_{2} \mathrm{~S}\right)$ conforme a reação indicada pela Equação (4.5). A solução rica em sulfeto era então submetida a fluxo de argônio gasoso (Ar) para o sttriping do $\mathrm{H}_{2} \mathrm{~S}$ produzido e a sua transferência do primeiro para o segundo frasco, onde era borbulhado na solução alcalina. Sempre que o pH da solução no segundo frasco caía em função do aumento da concentração de $\mathrm{H}_{2} \mathrm{~S}_{(\mathrm{aq})}$ (indicado pelo esmaecimento da coloração da fenolftaleína) injetava-se mais solução de $\mathrm{NaOH}$, garantindose uma retenção mais efetiva do sulfeto na fase líquida. 
Após cerca de 30 min sob fluxo de argônio, a solução alcalina do segundo frasco foi submetida à metodologia colorimétrica do azul de metileno (APHA/AWWA/WEF, 2005) para determinação da concentração de sulfeto total dissolvido (STD). Paralelamente, preparou-se uma solução de bicarbonato de sódio $\left(\mathrm{NaHCO}_{3}\right)$ em água deionizada com concentração final de $2 \mathrm{~g} \cdot \mathrm{L}^{-1}$ do íon bicarbonato $\left(\mathrm{HCO}_{3}{ }^{-}\right)$.

Alíquotas da solução de $\mathrm{H}_{2} \mathrm{~S}\left(\right.$ aq) e da solução de $\mathrm{NaHCO}_{3}$ foram combinadas com água deionizada e desoxigenada, de forma a resultarem em soluções padrões com concentrações conhecidas de bicarbonato $\left(1000,500\right.$ e $\left.300 \mathrm{mg} . \mathrm{L}^{-1}\right)$, sulfeto $\left(825,340,170\right.$ e $\left.150 \mathrm{mg} . \mathrm{L}^{-1}\right)$ e de ambos os ânions em mistura. Um volume de $50 \mathrm{~mL}$ de cada solução padrão foi submetido à titulação usando soluções de ácido sulfúrico com normalidades conhecidas $\left(\mathrm{H}_{2} \mathrm{SO}_{4} 0,8 \mathrm{~N}\right.$ ou $0,12 \mathrm{~N}$ ) até os valores de $\mathrm{pH}=5,75$ (Alcalinidade parcial) e 4,30 (Alcalinidade total), conforme metodologia proposta por RIPLEY et al. (1986). As titulações foram acompanhadas com auxílio de pH-metro. Antes de proceder à titulação das amostras contendo sulfeto, o pH das soluções foi ajustado para próximo de 8,30 com o mesmo ácido utilizado na titulação. Este passo foi adotado pois abaixo dessa faixa de $\mathrm{pH}$ a contribuição das alcalinidades devidas a hidróxidos $\left(\mathrm{OH}^{-}\right)$e a carbonatos $\left(\mathrm{CO}_{3}{ }^{2-}\right)$ pode ser considerada desprezível (JENKINS; MOORE, 1977). Todas as determinações foram efetuadas em triplicatas. Titulações de amostras contendo sulfeto foram realizadas na capela, sob exaustão.

Em seguida foram efetuados os cálculos da especiação do sulfeto dissolvido para determinação da concentração molar de $\mathrm{HS}^{-}$em cada amostra, conforme o equacionamento descrito posteriormente na subseção 4.13.3, p. 99. 
Considerando que $1 \mathrm{~mol}$ do ânion $\mathrm{HS}^{-}$é capaz de neutralizar $1 \mathrm{~mol}$ de íons $\mathrm{H}^{+}$para produzir o sulfeto de hidrogênio molecular $\left(\mathrm{H}_{2} \mathrm{~S}\right)$ (Equação (3.14)), a concentração molar de HS $^{-}$(Equação (4.31)) foi utilizada para estimar a alcalinidade devida ao sulfeto total dissolvido ( $\left.\mathrm{AHS}^{-}\right)$no efluente do reator, conforme o cálculo apresentado pela Equação (4.6).

$\mathrm{A}_{\mathrm{HS}^{-}}\left(\mathrm{mg} \mathrm{CaCO} 3 \cdot \mathrm{L}^{-1}\right)=\left[\mathrm{HS}^{-}\right] \times 50000$

$\mathrm{Na}$ qual 50000 é o equivalente-grama (massa molar/valência) do $\mathrm{CaCO}_{3}$, utilizado como referência nas medidas de alcalinidade.

Os resultados teóricos esperados foram comparados com os resultados obtidos pelo procedimento titulométrico de forma a se avaliar a aplicabilidade do equacionamento proposto na determinação da fração de alcalinidade devida a sulfeto.

Uma vez que o acúmulo de ácido acético $\left(\mathrm{CH}_{3} \mathrm{COOH}\right)$ é uma ocorrência frequentemente observada em reatores sulfetogênicos (GALLEGOS-GARCIA et al., 2009; NAGPAL et al., 2000; REIS et al., 1992) a capacidade tampão do sulfeto dissolvido também foi avaliada na presença desse ácido orgânico. Para este fim, uma outra série de soluções padrões $\left(300 \mathrm{mgHCO}{ }^{3-} . \mathrm{L}^{-1}, 150 \mathrm{mgHS}-. \mathrm{L}^{-1}\right.$ e $\left.300 \mathrm{mgHCO}^{3-} \cdot \mathrm{L}^{-1}+150 \mathrm{mgHS} \cdot \mathrm{L}^{-1}\right)$ foi titulada após a adição de ácido acético concentrado. As concentrações finais do ácido testadas foram $150 \mathrm{mg} \mathrm{CH} \mathrm{CHOH}_{3} \mathrm{~L}^{-1}$ (nas soluções com bicarbonato ou sulfeto) e $300 \mathrm{mg} \mathrm{CH}_{3} \mathrm{COOH}^{-1}$ (nas soluções com a mistura dos dois ânions). Soluções controle contendo apenas ácido acético também foram padronizadas por titulação entre valores de $\mathrm{pH}$ 5,75 até 4,30 (pH inicial ajustado com solução de $\mathrm{NaOH})$. 
Por fim, os consumos teóricos de alcalinidade foram estimados e comparados com os consumos observados. Para isto, considerou-se que $1 \mathrm{~g}$ de ácido acético consome 0,83 g de alcalinidade em termos de $\mathrm{CaCO}_{3}$.

Uma vez que os resultados obtidos foram considerados satisfatórios, indicando a validade do equacionamento teórico, os cálculos propostos foram utilizados para avaliar a contribuição do sulfeto dissolvido para com a alcalinidade do reator DFSBR operando sob diversas cargas de ferro (ETAPA 1) e valores de pH afluente decrescentes (ETAPA 3).

Já para a determinação da alcalinidade a bicarbonato real do sistema ( $\left.\mathrm{A}_{\mathrm{BIC}}\right)$, descontaram-se as contribuições do íon $\mathrm{HS}^{-}\left(\mathrm{A}_{\mathrm{HS}}\right.$ ) e dos ácidos voláteis totais (AAV) da alcalinidade total medida, conforme indicado na Equação (4.7).

$\mathrm{A}_{\mathrm{BIC}}\left(\mathrm{mg} \mathrm{CaCO} \cdot \mathrm{L}^{-1}\right)=\mathrm{A}_{\mathrm{T}}-\mathrm{AAV}-\mathrm{A}_{\mathrm{HS}}$

$\mathrm{Na}$ qual $\mathrm{A}_{\mathrm{T}}$ é a alcalinidade total no efluente do reator $\left(\mathrm{mgCaCO}_{3} \cdot \mathrm{L}^{-1}\right)$ medida por titulação ácida até $\mathrm{pH}=4,30 ; \mathrm{AAV}$ é a alcalinidade devida aos ácidos voláteis totais $\left(\mathrm{mgCaCO}_{3} \cdot \mathrm{L}^{-1}\right)$; e $\mathrm{A}_{\mathrm{HS}}$ é a alcalinidade a sulfeto estimada pela Equação (4.6) $\left(\mathrm{mgCaCO}_{3} \cdot \mathrm{L}^{-1}\right)$.

As alcalinidades total $\left(A_{T}\right)$, parcial $\left(A_{P}\right)$, intermediária $\left(A_{I}\right)$ e devida a ácidos voláteis totais (AAV), por sua vez, foram determinadas de acordo com os protocolos titulométricos habituais propostos por RIPLEY et al. (1986) e DILALLO; ALBERTSON (1961) (Tabela 4.6). As Equações utilizadas nos cálculos dessas variáveis são apresentadas na sequência:

$$
\mathrm{A}_{\mathrm{T}}=\frac{\mathrm{V}_{2} \times \mathrm{N}_{\mathrm{H}_{2} \mathrm{SO}_{4}} \times 50000}{\mathrm{~V}_{\mathrm{AMOSTRA}}}
$$


$\mathrm{A}_{\mathrm{P}}=\frac{\mathrm{V}_{1} \times \mathrm{N}_{\mathrm{H}_{2} \mathrm{SO}_{4}} \times 50000}{\mathrm{~V}_{\mathrm{AMOSTRA}}}$

$A_{I}=A_{T}-A_{P}$

$\mathrm{AAV}=\frac{\mathrm{V}_{3} \times \mathrm{N}_{\mathrm{NaOH}} \times 50000}{\mathrm{~V}_{\text {AMOSTRA }}}$

Na qual $V_{1}$ é o volume da solução de ácido sulfúrico utilizado na titulação da amostra até $\mathrm{pH}=5,75(\mathrm{~mL}) ; \mathrm{V}_{2}$ é o volume da solução de $\mathrm{H}_{2} \mathrm{SO}_{4}$ gasto até $\mathrm{pH}=4,30(\mathrm{~mL}) ; \mathrm{V}_{3}$ é o volume da solução de $\mathrm{NaOH}$ gasto para elevar o $\mathrm{pH}$ da amostra de 4,0 para 7,0 (mL); $\mathrm{N}_{\mathrm{H} 2 \mathrm{SO}}$ é a normalidade da solução de ácido sulfúrico $(\mathrm{N})$; e $\mathrm{N}_{\mathrm{NaOH}}$ é a normalidade da solução de hidróxido de sódio (N).

\subsection{Ensaios hidrodinâmicos}

Ensaios hidrodinâmicos foram realizados no início da ETAPA 2, visando caracterizar o padrão de escoamento do reator de leito fixo-estruturado e fluxo descendente (DFSBR) sob diferentes razões de recirculação. $\mathrm{O}$ experimento seguiu a metodologia adaptada por ANZOLA-ROJAS (2014), baseada no estímulo em degrau invertido, para evitar que o traçador empregado, pela diferença de densidade, não acompanhasse adequadamente o escoamento do reator de fluxo descendente.

No presente estudo, o ensaio consistiu em encher o volume do reator com o efluente sintético, cuja condutividade era conhecida, provocando em seguida um estímulo em degrau invertido por meio da alimentação do sistema com água residuária sintética sem a adição de cloreto de potássio $(\mathrm{KCl})$. Essa foi a alternativa encontrada para a realização de ensaios hidrodinâmicos que resultassem na descrição do regime de escoamento do reator em operação, ou seja, levando-se em conta a presença de biomassa aderida ao material suporte e a 
geração de turbulência devida ao biogás. $\mathrm{KCl}$ foi escolhido como traçador por ser um constituinte expressivo do meio sintético e por não se tratar de um nutriente indispensável para a manutenção do reator em pleno funcionamento durante o ensaio. Antes da inoculação e partida do sistema também foi realizado um ensaio hidrodinâmico para determinar o padrão de escoamento do reator fora de operação seguindo o mesmo protocolo experimental.

Uma sonda de condutividade Vernier CON-BTA (Vernier Software \& Technology, Beaverton OR, USA) foi instalada na saída de efluente do reator, acoplada a uma interface USB Go!Link (Vernier Software \& Technology, Beaverton OR, USA) conectada a um computador. Foram adquiridos dados com intervalo de 3 minutos durante tempo superior a três vezes o TDH teórico $(3 \times 20$ h). A aquisição de dados foi realizada com apoio do software Logger Lite 1.6.1 (Vernier Software \& Technology, Beaverton OR, USA).

Para minimizar interferências devidas a ruídos na curva de resposta obtida, os dados experimentais de cada ensaio foram ajustados a curvas sigmoidais ou polinomiais de quarto grau com coeficientes de correlação $\left(\mathrm{R}^{2}\right)$ maiores que 0,99 . As curvas ajustadas, traçadas com auxílio do software OriginPro 8 (OriginLab Corporation, Northamptom, MA, USA), foram utilizadas no lugar das curvas originais para a obtenção das curvas de resposta normalizadas (Curva F), conforme a Equação (4.12) (LEVENSPIEL, 2000).

$$
F=\frac{C}{C_{M A ́ x}}
$$

$\mathrm{Na}$ qual $\mathrm{C}$ é a concentração do traçador; e $\mathrm{C}_{\mathrm{MÁx}}$ é a sua concentração máxima detectada.

Já que no presente caso o ensaio foi realizado de maneira invertida, a curva de resposta foi convertida em curva $\mathrm{F}_{\mathrm{i}}$ conforme a Equação (4.13). 
$\mathrm{F}_{\mathrm{i}}=1-\mathrm{F}$

A curva $F_{i}$ foi então transformada na curva de distribuição do TDH (Curva E), conforme Equação (4.14). A partir da curva E determinou-se o TDH médio do reator, de acordo com a Equação (4.15) (LEVENSPIEL, 2000).

$\mathrm{E}=\frac{\mathrm{dF}}{\mathrm{dt}} \cong \frac{\Delta \mathrm{F}}{\Delta \mathrm{t}}$

$\overline{\theta \mathrm{h}}=\frac{\int_{0}^{\infty} \mathrm{t} \cdot \mathrm{E}(\mathrm{t}) \cdot \mathrm{dt}}{\int_{0}^{\infty} \mathrm{E}(\mathrm{t}) \cdot \mathrm{dt}} \cong \frac{\sum_{0}^{\mathrm{n}} \mathrm{t} \cdot \mathrm{E}(\mathrm{t}) \cdot \Delta \mathrm{t}}{\sum_{0}^{\mathrm{n}} \mathrm{E}(\mathrm{t}) \cdot \Delta \mathrm{t}}$

Na qual $\overline{\theta h}$ é o TDH médio obtido (h); e n é o número de medições realizadas durante o ensaio hidrodinâmico.

A partir do cálculo da variância da curva normalizada (Equação (4.16)) e da variância adimensional (Equação (4.17)) calculou-se o número $(\mathrm{N})$ de tanques de mistura completa em série (Equação (4.18)) para representação do padrão de escoamento do DFSBR (LEVENSPIEL, 2000).

$$
\begin{aligned}
& \sigma^{2}=\int_{0}^{\infty}(\mathrm{t}-\overline{\theta \mathrm{h}})^{2} \cdot \mathrm{E}(\mathrm{t}) \cdot \mathrm{dt} \cong \sum_{0}^{\mathrm{n}}(\mathrm{t}-\overline{\theta \mathrm{h}})^{2} \cdot \mathrm{E}(\mathrm{t}) \cdot \Delta \mathrm{t} \\
& \sigma_{\Theta}^{2}=\frac{\sigma^{2}}{\overline{\theta_{\mathrm{h}}^{2}}} \\
& \mathrm{~N}=\frac{1}{\sigma_{\Theta}^{2}}
\end{aligned}
$$

Na qual $\sigma^{2}$ é a variância da curva normalizada (h); $\sigma_{\Theta}^{2}$ é a variância adimensional; e $N$ é o número de reatores de mistura completa em série. 


\subsection{Avaliação da cinética de remoção de matéria orgânica e sulfato no DFSBR}

Foram realizados ensaios em batelada no reator DFSBR para avaliar a cinética aparente de degradação da matéria orgânica e de redução de sulfato a partir da água residuária orgânica utilizada (vinhaça), de etanol e ácido lático (doadores de elétrons comumente empregados no tratamento de DAM) e dos ácidos acético e propiônico. Esses últimos dois substratos foram utilizados para avaliar a atividade acetotrófica e hidrogenotrófica da biomassa estabelecida no DFSBR.

Os ensaios foram realizados ao final da operação do reator durante a ETAPA 2. O reator foi mantido com vazão de reciclo da fase líquida correspondente a 100 vezes a vazão afluente durante a operação contínua do reator. A recirculação foi mantida durante os testes cinéticos para assegurar adequadas condições de mistura no interior do sistema.

Ao início de cada ensaio o reator foi drenado e preenchido rapidamente com meio contendo DQO próxima de $1100 \mathrm{mg} . \mathrm{L}^{-1}$ e concentração de sulfato da ordem de $600 \mathrm{mg} . \mathrm{L}^{-1}$ (relação $\mathrm{DQO} / \mathrm{SO}_{4}{ }^{2-} \approx 2,0$ ). $\mathrm{O} \mathrm{pH}$ inicial foi ajustado em 7,20 por meio da dosagem de uma solução concentrada de $\mathrm{NaOH}$. Os valores iniciais de $\mathrm{pH}$ foram mantidos próximos dos valores medidos no interior do reator durante a ETAPA 2 (dados não mostrados). A concentração inicial de DQO foi escolhida de maneira a não causar sobrecargas no sistema, evitando-se ultrapassar em demasia os valores de DQO medidos ao longo do DFSBR durante o perfil de concentrações espaciais determinado ao final da FASE 2B (dados a serem mostrados na Figura 5.32.a).

No ensaio com vinhaça real, a mesma foi diluída para a DQO desejada e recebeu dosagem complementar de sulfato de sódio, sem adição de outros nutrientes. Já para os testes com os outros doadores de elétrons preparou-se um meio sintético obedecendo a mesma 
composição utilizada durante a ETAPA 1 (Tabela 4.2), diluída para a DQO de 1100 mg.L ${ }^{-1}$, e excetuando-se a adição dos componentes orgânicos, os quais foram substituídos exclusivamente pelo substrato a ser testado como doador de elétrons. Vitaminas e micronutrientes também foram adicionados (Tabela 4.3).

Amostras foram coletadas no início do ensaio e a cada intervalo de 60 min para a realização de análises de DQO, sulfato, sulfeto e pH durante as primeiras $10 \mathrm{~h}$ de ensaio. Uma amostra coletada após $24 \mathrm{~h}$ do início do ensaio também foi analisada. As amostras eram retiradas diretamente da linha de reciclo do sistema. Uma vez que o volume útil do DFSBR é da ordem de 1,7 $\mathrm{L}$, foram retirados $10 \mathrm{~mL}$ de amostra em cada coleta, resultando em um volume total retirado de $120 \mathrm{~mL}$, respeitando-se o limite máximo de $10 \%$ do volume útil do reator $(=170 \mathrm{~mL})$.

Coeficientes cinéticos aparentes de primeira ordem foram estimados a partir do decaimento temporal das concentrações de DQO $\left(\mathrm{k}_{1}{ }^{\mathrm{DQO}}, \mathrm{h}^{-1}\right)$ e sulfato $\left(\mathrm{k}_{1}{ }^{\mathrm{SO} 4}, \mathrm{~h}^{-1}\right)$ em cada ensaio. O modelo aplicado para o ajuste do decaimento da matéria orgânica (Equação (4.19)) consistiu de uma adaptação do modelo de Monod, levando em conta uma concentração remanescente de DQO e baixo rendimento celular (MOCKAITIS et al., 2012). Já o decaimento de sulfato foi ajustado ao modelo cinético de primeira ordem sem concentração residual (Equação (4.20)).

Os ajustes matemáticos dos dados experimentais às Equações (4.19) e (4.20) foram realizados com auxílio do software OriginPro 8 (OriginLab Corporation, Northamptom, MA, USA), aplicando o algoritmo de Levenberg-Maquardt. Os respectivos coeficientes específicos de primeira ordem $\left(\mathrm{k}_{1 \mathrm{sp}}^{\mathrm{DQO}}\right.$ e $\left.\mathrm{k}_{1 \mathrm{sp}}{ }^{\mathrm{SO}}, \mathrm{gSSV}^{-1} \cdot \mathrm{h}^{-1}\right)$ foram obtidos dividindo-se $\mathrm{k}_{1}^{\mathrm{DQO}}$ e $\mathrm{k}_{1}^{\mathrm{SO} 4}$ pela quantidade de biomassa aderida (em termos de SSV) ao final da operação do reator DFSBR. 


$$
\begin{aligned}
& \mathrm{C}_{\mathrm{DQO}}(\mathrm{t})=\mathrm{C}_{\mathrm{DQO}}{ }^{\text {Residual }}+\left(\mathrm{C}_{\mathrm{DQO}}{ }^{0}-\mathrm{C}_{\mathrm{DQO}}{ }^{\text {Residual }}\right) \cdot \exp \left(-\mathrm{k}_{1}{ }^{\mathrm{DQO}} \cdot \mathrm{t}\right) \\
& \mathrm{C}_{\mathrm{SO} 4}(\mathrm{t})=\mathrm{C}_{\mathrm{SO} 4}{ }^{0} \cdot \exp \left(-\mathrm{k}_{1}{ }^{\mathrm{SO} 4} \cdot \mathrm{t}\right)
\end{aligned}
$$

Onde C (t) é a concentração do substrato de interesse (DQO ou sulfato) medida no tempo $t\left(m g . L^{-1}\right) ; C^{0}$ é a concentração inicial $(t=0)$ do substrato de interesse $\left(m g . L^{-1}\right) ; C^{\text {Residual }}$ é a concentração residual de substrato $\left(\mathrm{mg} . \mathrm{L}^{-1}\right) ; \mathrm{k}_{1}$ o coeficiente cinético aparente de primeira ordem $\left(\mathrm{h}^{-1}\right)$; e t é o tempo do ensaio $(\mathrm{h})$.

Nos intervalos entre cada ensaio o reator foi mantido por $24 \mathrm{~h}$ em descanso, sendo a DQO e o sulfato ajustados aos níveis iniciais com dosagem da água residuária original (vinhaça).

\subsection{Microscopia óptica}

Amostras coletadas do material suporte do reator ao final da FASE 1A foram analisadas utilizando técnicas de microscopia óptica de luz comum e contraste de fase em Microscópio Olympus BX60 (Olympus Optical Co. Ltd., Tóquio, Japão) acoplado à câmera com captura de imagem Evolution QE e software Image-Pro Plus 4.5 (Media Cybernetics, Silver Spring, MD, USA) para determinação das principais morfologias estabelecidas no biofilme.

\subsection{Análise da diversidade microbiana (PCR/DGGE)}

A avaliação da diversidade microbiana (Domínios Archaea e Bacteria) foi realizada por meio das técnicas de reação em cadeia polimerase (Polymerase chain reaction - PCR) 
seguida de eletroforese em gel de gradiente desnaturante (Denaturing gradient gel electrophoresis - DGGE), baseando-se no protocolo experimental descrito por GRIFFITHS et al. (2000).

A técnica de PCR/DGGE consistiu, basicamente, de três etapas: 1) Extração do DNA ribossomal; 2) amplificação por reação em cadeia de polimerase dos fragmentos de interesse; 3) separação dos fragmentos-alvos pela desnaturação parcial da dupla-hélice.

Foram analisadas amostras dos dois inóculos utilizados (IN-1 e IN-2), bem como amostras de biomassa do reator retiradas do material suporte ao final das FASES 1A e 1E (ETAPA 1), ao final das FASES 2A, 2B e 2E (ETAPA 2), e ao final das FASES 3A, 3B, 3E e 3G (ETAPA 3). Para a composição de cada amostra em questão, várias frações de biomassa foram colhidas em diversos pontos do material suporte e homogeneizadas com o intuito de permitir uma análise da diversidade populacional representativa do reator como um todo.

Previamente à extração do DNA, as amostras foram lavadas sucessivas vezes com tampão fosfato salino (Phosphate-buffered saline - PBS 1X: $130 \mathrm{mM} \mathrm{NaCl} ; 7 \mathrm{mM} \mathrm{Na}_{2} \mathrm{HPO}_{4}$; $\left.3 \mathrm{mM} \mathrm{NaH}{ }_{2} \mathrm{PO}_{4} ; \mathrm{pH}=7,20\right)$, centrifugadas a $4^{\circ} \mathrm{C}(8000 \mathrm{rpm}$ durante $10 \mathrm{~min})$ e os pellets armazenados à temperatura de $-20^{\circ} \mathrm{C}$.

A extração do DNA foi efetuada utilizando-se glass beads, fenol tamponado com Tris e clorofórmio, conforme protocolo de GRIFFITHS et al. (2000) modificado. Maior detalhamento do procedimento adotado pode ser encontrado em DELFORNO (2014).

Para a amplificação dos fragmentos de interesse do gene RNAr 16S do DNA extraído foram utilizados os set-primers 1100FGC - 1401R, para o Domínio Archaea (KUDO et al., 1997), e 968FGC - 1401R, para o Domínio Bacteria (NUBEL et al., 1996). A PCR foi realizada em termociclador Eppendorf Mastercycler AG 22331 (Eppendorf, Hamburg, Alemanha), obedecendo às condições indicadas na Tabela 4.7. 
Tabela 4.7: Condições utilizadas no programa de PCR para os Domínios Archaea e Bacteria.

\begin{tabular}{llllllll}
\hline Domínio & $\begin{array}{l}\text { Pré- } \\
\text { desnaturação }\end{array}$ & $\begin{array}{l}\mathbf{N}^{\mathbf{0}} \text { de } \\
\text { ciclos }\end{array}$ & Desnaturação & Anelamento & Extensão & $\begin{array}{l}\text { Final da } \\
\text { extensão }\end{array}$ & Resfriamento \\
\hline Archaea $^{(1)}$ & $94^{\circ} \mathrm{C}$ & 35 & $94^{\circ} \mathrm{C}$ & $55^{\circ} \mathrm{C}$ & $72^{\circ} \mathrm{C}$ & $72^{\circ} \mathrm{C}$ & $4^{\circ} \mathrm{C}$ \\
& $90 \mathrm{~s}$ & & $30 \mathrm{~s}$ & $30 \mathrm{~s}$ & $90 \mathrm{~s}$ & $3 \mathrm{~min}$ & \\
\hline Bacteria $^{(2)}$ & $94^{\circ} \mathrm{C}$ & 35 & $94^{\circ} \mathrm{C}$ & $63^{\circ} \mathrm{C}$ & $72^{\circ} \mathrm{C}$ & $72^{\circ} \mathrm{C}$ & $4^{\circ} \mathrm{C}$ \\
& $5 \mathrm{~min}$ & & $1 \mathrm{~min}$ & $1 \mathrm{~min}$ & $1 \mathrm{~min}$ & $5 \mathrm{~min}$ & \\
\hline
\end{tabular}

Fonte: ${ }^{(1)}$ KUDO et al., 1997; ${ }^{(2)}$ NUBEL et al., 1996.

Os produtos da PCR foram aplicados em gel de poliacrilamida $8 \%$ em TAE 1X, com gradiente linear de desnaturante (ureia e formamida) variando de 45 a $65 \%$. A eletroforese foi efetuada em voltagem constante $(75 \mathrm{~V})$, a temperatura de $60^{\circ} \mathrm{C}$ por $16 \mathrm{~h}$. Em seguida o gel foi corado em solução de brometo de etídio e a imagem capturada em equipamento Eagle Eye II (Stratagene, La Jolla, CA, USA) sob iluminação UV de $254 \mathrm{~nm}$. O perfil do DGGE foi analisado com auxílio do software Bionumerics 2.5 (Applied Maths, Ghent, Bélgica). Os coeficientes de similaridade foram determinados pelo coeficiente de correlação de Pearson e os dendrogramas pelo algoritmo UPGMA (unweighted pair group method with arithmetic averages).

\subsection{Caracterização microbiana por sequenciamento do RNAr 16S}

As amostras de DNA extraídas conforme o protocolo indicado anteriormente na seção 4.11, p. 93, a partir da biomassa coletada ao final das FASES 3B e 3G foram enviadas para sequenciamento do gene RNAr 16 S através da plataforma Illumina Miseq no Mr. DNA Lab (www.mrdnalab.com, Shallowater, Texas, EUA). Foram utilizados os primers 515F (5'-CACGACGTTGTAAAACGACGTGCCAGCMGCCGCGGTAA-3') e 806R (5'-CAGGAAACAGCTATGACCGGACTACVSGGGTATCTAAT-3'), os quais são 
específicos para amplificação da região variável V4 do gene RNAr 16S (CAPORASO et al., 2012).

O processamento dos dados foi realizado utilizando o QIIME pipeline. Foram removidas as sequências com menos de 150 pares de bases e adotou-se similaridade de $97 \%$ para determinação das Unidades Taxinômicas Operacionais (Operational Taxonomic Unit OTUs). Após a remoção de singletons (OTUs com apenas uma sequência) e quimeras. A classificação taxonômica das OTUs finais foi determinada utilizando-se bases de dados derivadas do GreenGenes, RDPII4 e NCBI5 (DESANTIS et al., 2006). Foram definidos limites confiáveis de $80 \%$ para gênero e $50 \%$ para outros níveis taxonômicos. No ambiente estatístico do R, a tabela de contagem e metadados foram importados como objeto phyloseq para rarefação, análise de alfa e beta diversidade, análises estatísticas e gráficos (phyloseq software, McMURDIE; HOLMES, 2013).

\subsection{Parâmetros Calculados}

\subsubsection{Vias de remoção da matéria orgânica}

Em sistemas metanogênicos e sulfetogênicos simultâneos enquanto uma parcela da matéria orgânica $\left(\mathrm{DQO}_{\mathrm{CH} 4}\right)$ é oxidada na etapa final da digestão anaeróbia pelo metabolismo das arqueias metanogênicas (AM), sendo convertida a $\mathrm{CH}_{4}$ e $\mathrm{CO}_{2}$, outra parcela é utilizada como doador de elétrons nas reações de redução de sulfato a sulfeto pelas BRS (DQO $\left.\mathrm{SO}_{4}\right)$.

Uma vez que para a redução de $1 \mathrm{~g}$ de $\mathrm{SO}_{4}{ }^{2-}$ se faz necessária a oxidação de $0,67 \mathrm{~g}$ de matéria orgânica (DQO) pelo metabolismo das BRS (LENS et al., 1998), estimou-se o fluxo de elétrons requerido pela via sulfetogênica conforme indicado na Equação (4.22). Já para 
estimar o fluxo de elétrons demandado pela via metanogênica (Equação (4.23)) considerou-se que cada $1 \mathrm{~g}$ de DQO consumida pelas AM rende $350 \mathrm{~mL}$ de metano sob condições normais de temperatura e pressão $\left(\mathrm{CNTP}-0^{\circ} \mathrm{C}\right.$ e $\left.1 \mathrm{~atm}\right)$ (SPEECE, 1996). Neste último caso também foi levada em conta a parcela de metano dissolvido estimada no efluente do reator, conforme descrito na subseção 4.13.2, p. 98.

Vale ressaltar que os cálculos aqui apresentados não levam em conta a quantia de matéria orgânica diretamente convertida em biomassa (síntese celular) ou utilizada nos processos de manutenção do biofilme. Apenas a fração de DQO em suspensão no efluente $\left(\right.$ DQO $\left._{\text {SUSPENSA }}{ }^{\mathrm{EF}}\right)$ foi considerada, a qual corresponde aos sólidos suspensos voláteis (SSV) produzidos pelo sistema e arrastados pelo cisalhamento ou desprendimento do biofilme.

$$
\begin{aligned}
& \mathrm{DQO}_{\text {REMOVIDA }}=\mathrm{DQO}_{\text {AFLUENTE }}-\mathrm{DQO}_{\text {ORGÂNICA }}{ }^{\mathrm{EF}} \\
& \mathrm{DQO}_{\mathrm{SO} 4}(\%)=\frac{0,67 \times\left(\mathrm{SO}_{4}{ }^{\mathrm{AF}}-\mathrm{SO}_{4}{ }^{\mathrm{EF}}\right)}{\mathrm{DQO}_{\text {REMOVIDA }}} \times 100 \\
& \mathrm{DQO}_{\mathrm{CH} 4}(\%)=\frac{\mathrm{V}_{\mathrm{CH} 4}}{350 \times 10^{-6} \times \mathrm{DQO}_{\text {REMOVIDA }} \times \mathrm{Q}_{\mathrm{AFL}}} \\
& \mathrm{DQO}_{\mathrm{SSV}}(\%)=\frac{\mathrm{DQO}_{\text {SUSPENSA }}}{\mathrm{DQO}_{\text {REMOVIDA }}} \times 100
\end{aligned}
$$

$\mathrm{Na}$ qual DQO $\mathrm{REMOVIDA}_{\mathrm{A}}$ é a diferença entre as concentrações de DQO solúvel no afluente e no efluente do reator $\left(\mathrm{mgO}_{2} \cdot \mathrm{L}^{-1}\right) ; \mathrm{DQO}_{\mathrm{SO} 4}$ é a porcentagem da DQO $\mathrm{REMOVIDA}_{\text {que }}$ foi convertida via redução de sulfato $(\%) ; \mathrm{SO}_{4}{ }^{\mathrm{AF}}$ e $\mathrm{SO}_{4}{ }^{\mathrm{EF}}$ são, respectivamente, as concentrações de sulfato dissolvido no afluente e no efluente do reator $\left(\mathrm{mgSO}_{4}{ }^{2-} \cdot \mathrm{L}^{-1}\right)$;

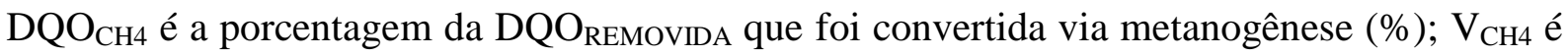


a vazão total de metano produzido (L.d $\left.{ }^{-1}\right)$ determinada pela Equação (4.27), mostrada na

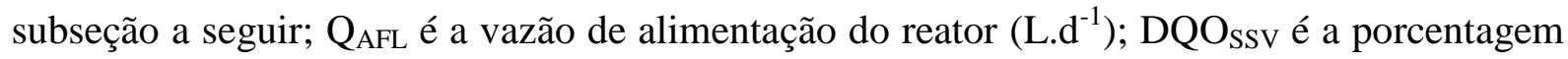
de DQO removida que foi convertida a sólidos suspensos voláteis medidos no efluente do reator (\%); e DQO ${ }_{\text {SUSPENSA }}{ }^{\mathrm{EF}}$ é a concentração de DQO orgânica em suspensão no efluente do reator $\left(\mathrm{mgO}_{2} \cdot \mathrm{L}^{-1}\right)$ calculada conforme Equação (4.3).

\subsubsection{Estimativa do metano dissolvido}

A fração de metano que se encontra dissolvida no meio líquido, sendo perdida com o efluente do reator (GIMÉNEZ et al., 2012), foi estimada conforme o cálculo apresentado na Equação (4.25).

$\mathrm{X}_{\mathrm{CH} 4}=\mathrm{P}_{\mathrm{CH} 4} \times \mathrm{K}_{\mathrm{H}}{ }^{\mathrm{CH} 4}$

$\mathrm{Na}$ qual $\mathrm{X}_{\mathrm{CH} 4}$ é a concentração molar de metano dissolvida no meio líquido (mol. $\mathrm{L}^{-1}$ ); $\mathrm{P}_{\mathrm{CH} 4}$ é a pressão parcial de metano medida no headspace do reator (atm); e $\mathrm{K}_{\mathrm{H}}{ }^{\mathrm{CH} 4}$ é a constante da Lei de Henry para o metano nas condições experimentais (mol. $\left.\mathrm{L}^{-1} \cdot \mathrm{atm}^{-1}\right)$.

A constante de Henry foi calculada conforme indicações reportadas por SANDER (2014), tendo sido determinado o valor de $\mathrm{K}_{\mathrm{H}}{ }^{\mathrm{CH} 4}=1,36 \times 10^{-3} \mathrm{~mol} \cdot \mathrm{L}^{-1} \cdot \mathrm{atm}^{-1}$ a $30^{\circ} \mathrm{C}$.

A concentração de metano dissolvido no efluente foi então transformada em termos de vazão (Equação (4.26)) e somada à vazão de metano no biogás para determinação da vazão total de metano produzido $\left(\mathrm{V}_{\mathrm{CH} 4}\right)$ (Equação (4.27).

$\mathrm{V}_{\mathrm{CH} 4}{ }^{\mathrm{DISS}}=\mathrm{Q}_{\mathrm{AFL}} \times \frac{\mathrm{X}_{\mathrm{CH} 4} \times \mathrm{R} \times \mathrm{T}}{\mathrm{P}}$ 


$$
\mathrm{V}_{\mathrm{CH} 4}=\mathrm{V}_{\mathrm{CH} 4}{ }^{\text {BIOGÁS }}+\mathrm{V}_{\mathrm{CH} 4} \text { DISS }
$$

$\mathrm{Na}$ qual $\mathrm{V}_{\mathrm{CH} 4}{ }^{\text {DISS }}$ é a vazão estimada de metano dissolvido no efluente do reator

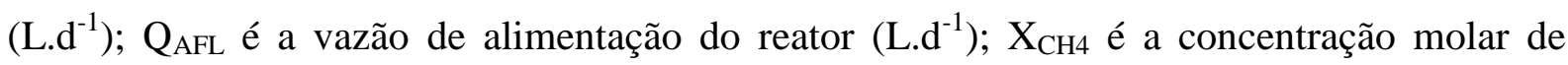
metano dissolvida no meio líquido $\left(\right.$ mol. $\left.\mathrm{L}^{-1}\right)$; $\mathrm{R}$ é a constante universal dos gases ideais $(\mathrm{R} \approx$ 0,08206 atm.L.mol $\left.{ }^{-1} \cdot \mathrm{K}^{-1}\right) ; \mathrm{T}$ é a temperatura absoluta das condições experimentais $(\mathrm{T}=$

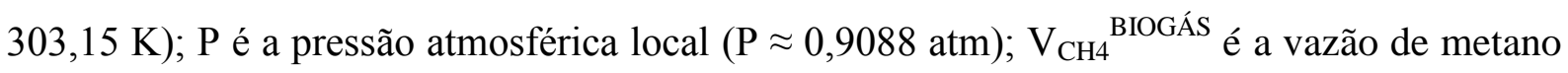
medido no biogás (L.d $\left.{ }^{-1}\right)$; e $\mathrm{V}_{\mathrm{CH} 4}$ é a vazão total de metano produzido (L.d ${ }^{-1}$ ).

Vale ressaltar que a concentração de metano dissolvido regida pela Lei de Henry é válida em condições estritas de equilíbrio da interface líquido-gás, o que não ocorre facilmente em sistemas anaeróbios em função da liberação constante de biogás. De qualquer forma, os resultados obtidos pelo presente cálculo foram utilizados apenas como uma estimativa aproximada do metano que é perdido em solução com o efluente do reator. Embora potencialmente subestimada, essa fração de metano dissolvido foi levada em conta para o levantamento dos balanços de massa de interesse.

\subsubsection{Especiação do sulfeto total dissolvido}

O sulfeto produzido pelo metabolismo das BRS pode se encontrar dissolvido sob a forma das espécies $\mathrm{H}_{2} \mathrm{~S}$ aquoso (sulfeto de hidrogênio dissolvido), $\mathrm{HS}^{-}$(íon bissulfeto) e $\mathrm{S}^{2-}$ (íon dissulfeto). Esse equilíbrio é regido pelo $\mathrm{pH}$ do meio líquido, conforme mostrado anteriormente na Figura 3.3.

Uma vez que o $\mathrm{pKa}^{2}$ do equilíbrio do sulfeto dissolvido está além da faixa de $\mathrm{pH}$ característica dos processos anaeróbios $\left(6,0\right.$ a 8,0) (Equação (3.15)), a concentração do íon $S^{2-}$ pode ser considerada desprezível (LENS et al., 1998). 
Partindo da definição da constante de dissociação (Kpa ${ }^{1}$ ) do par $\mathrm{H}_{2} \mathrm{~S} \mathrm{HS}^{-}$(Equação (4.28)), igualou-se o logaritmo negativo dessa expressão ao $\mathrm{pKa}^{1}$ (Equação (4.29)). Para resolução do equacionamento foi assumida a simplificação de que $\mathrm{pH}=-\log \left[\mathrm{H}^{+}\right]$. A concentração molar de sulfeto total dissolvido [STD], determinada analiticamente, também foi considerada como sendo a soma das concentrações molares de ambas as espécies dissolvidas em questão (Equação (4.30)). Após algumas manipulações algébricas, baseadas nas propriedades matemáticas do logaritmo, chegou-se à Equação (4.31), a qual permite determinar a parcela de sulfeto total na forma ionizada.

$$
\begin{aligned}
& \mathrm{Kp}_{\mathrm{a}^{1}}=\frac{\left[\mathrm{HS}^{-}\right] \times\left[\mathrm{H}^{+}\right]}{\left[\mathrm{H}_{2} \mathrm{~S}\right]} \\
& \mathrm{pKa}^{1}=-\log \left(\frac{\left[\mathrm{HS}^{-}\right] \times\left[\mathrm{H}^{+}\right]}{\left[\mathrm{H}_{2} \mathrm{~S}\right]}\right) \\
& {[\mathrm{STD}]=\left[\mathrm{HS}^{-}\right]+\left[\mathrm{H}_{2} \mathrm{~S}\right]} \\
& {\left[\mathrm{HS}^{-}\right]=\frac{\left[\mathrm{STD}^{2}\right]}{1+10^{\mathrm{pKa}^{1}-\mathrm{pH}}}}
\end{aligned}
$$

Na qual [STD] é a concentração molar de sulfeto total dissolvido no efluente do reator $\left(\right.$ mol. $\left.\mathrm{L}^{-1}\right) ;\left[\mathrm{HS}^{-}\right]$é a concentração molar do íon bissulfeto $\left(\mathrm{mol} . \mathrm{L}^{-1}\right)$; e $\left[\mathrm{H}_{2} \mathrm{~S}\right]$ é a concentração molar de sulfeto de hidrogênio dissolvido $\left(\mathrm{mol} \cdot \mathrm{L}^{-1}\right)$.

Nas condições ambientais $\left(25^{\circ} \mathrm{C}\right.$ e 1 atm) o $\mathrm{pKa}^{1}$ do par $\mathrm{H}_{2} \mathrm{~S} / \mathrm{HS}^{-}$é da ordem de 6,99 (LENS et al., 1998). 


\subsubsection{Eficiência de remoção de ferro}

Uma vez que a dosagem do cloreto ferroso se deu na entrada do reator, com vazão diferente da dosagem do meio sintético orgânico, utilizou-se a Equação (4.32) para determinar a concentração de ferro total no afluente. Partindo dos resultados das análises de ferro total no efluente, as eficiências de remoção de ferro do sistema foram calculadas conforme a Equação (4.33).

$$
\begin{aligned}
& \mathrm{Fe}_{\mathrm{AF}}=\frac{\mathrm{Fe}_{\text {estoque }} \times \mathrm{Q}_{\mathrm{Fe}}}{\mathrm{Q}_{\mathrm{AFL}}} \\
& \mathrm{E}_{\mathrm{Fe}}(\%)=\frac{\left(\mathrm{Fe}_{\mathrm{AF}}-\mathrm{Fe}_{\mathrm{EF}}\right)}{\mathrm{Fe}_{\mathrm{AF}}} \times 100
\end{aligned}
$$

Na qual $\mathrm{Fe}_{\mathrm{AF}}$ é a concentração estimada de ferro afluente do reator (mg.L $\left.{ }^{-1}\right) ; \mathrm{Fe}_{\text {estoque }}$ é a concentração de ferro no reservatório estoque da DAM sintética $\left(\mathrm{mg} . \mathrm{L}^{-1}\right) ; \mathrm{Fe}_{\mathrm{EF}}$ é a concentração de ferro no efluente do reator $\left(m g . L^{-1}\right)$; $Q_{\mathrm{Fe}}$ é a vazão da solução de cloreto ferroso $\left(L . h^{-1}\right)$; Q Q remoção de ferro no sistema (\%).

\subsubsection{Estimativa do potencial de produção de energia a partir do biogás no DFSBR}

Finalmente, para fins ilustrativos, pretendeu-se estimar o potencial de produção de energia (PPE) a partir do biogás gerado no DFSBR tratando DAM utilizando vinhaça concentrada de cana-de-açúcar como doador de elétrons. Para efeito de cálculo considerou-se o conteúdo energético do metano $\left(\mathrm{CE}_{\mathrm{CH} 4}\right)$ de $10 \mathrm{KWh} / \mathrm{m}^{3}$ e uma eficiência elétrica de um 
motor de ciclo combinado $(\eta)$ da ordem de 36\% (CABRAL et al., 2017). Em seguida, tomando por base a produção de metano estimada ao longo da ETAPA 3, foram definidos os rendimentos de metano por unidade de volume de vinhaça $\left(\operatorname{Rend}_{\mathrm{CH} 4}\right)$ dosado no sistema em cada condição operacional testada. Assim, a Equação (4.34) foi aplicada:

$$
\mathrm{PPE}=\operatorname{Rend}_{\mathrm{CH} 4} \times \mathrm{CE}_{\mathrm{CH} 4} \times \eta
$$

Na qual PPE é o potencial de produção de energia a partir do biogás gerado no sistema por unidade de volume de vinhaça utilizada $\left(\mathrm{KWh} / \mathrm{L}\right.$ vinhaça); Rend $_{\mathrm{CH} 4}$ é o rendimento observado de $\mathrm{CH}_{4}$ por unidade de volume de vinhaça utilizado $\left(\mathrm{m}^{3} \mathrm{CH}_{4} \cdot \mathrm{m}^{3}\right.$ vinHAÇA $\left.{ }^{-1}\right)$; $\mathrm{CE}_{\mathrm{CH} 4}$ é o conteúdo energético do metano $\left(10 \mathrm{KWh} \cdot \mathrm{m}^{3} \mathrm{CH}_{4}{ }^{-1}\right)$; e $\eta$ é a eficiência estimada de um motor de ciclo combinado (36\%).

Uma vez que a concentração média de DQO no afluente do reator foi mantida próxima de $4000 \mathrm{mg} . \mathrm{L}^{-1}$, e uma vinhaça concentrada com cerca de $120000 \mathrm{mg} . \mathrm{L}^{-1}$ de DQO foi utilizada como doador de elétrons (Tabela 4.5), cerca de 33,3 mL de vinhaça concentrada foram diluídos em $1000 \mathrm{~mL}$ da DAM a ser tratada. Assim, em um caso real, para cada $1 \mathrm{~m}^{3} \mathrm{de}$ DAM, 33,3 L de vinhaça seriam exigidos. Portanto, para cálculo do rendimento observado de metano por volume de vinhaça foi utilizada a Equação (4.35):

$$
\operatorname{Rend}_{\mathrm{CH} 4}=\frac{\mathrm{V}_{\mathrm{CH} 4}{ }^{\text {BIOGÁS }}}{\mathrm{Q}_{\mathrm{AFL}} \times\left(\frac{33,3}{1000}\right)}
$$




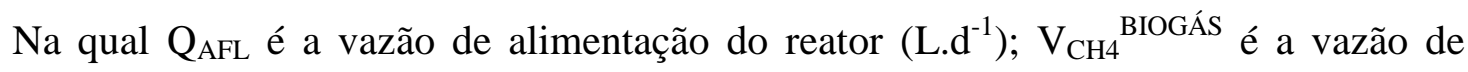

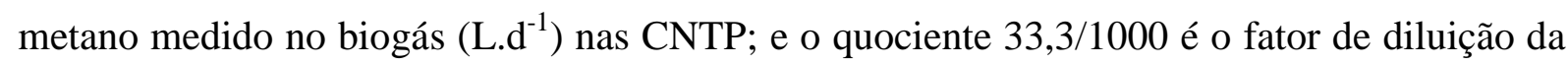
vinhaça concentrada no meio de alimentação do reator.

Vale ressaltar que os cálculos propostos na presente subseção foram efetuados apenas com intuito ilustrativo, de forma que várias simplificações foram implicitamente adotadas. É fato que o transporte de grandes volumes de vinhaça (mesmo concentrada) implicam em custos impeditivos para a manutenção do sistema de tratamento utilizando o substrato em questão como doador de elétrons, a não ser em casos específicos, nos quais há proximidade entre as unidades geradoras de vinhaça e DAM.

\subsection{Análises Estatísticas}

Os resultados relativos às cargas de matéria orgânica, sulfato e ferro removidas, bem como os valores de produção volumétrica de metano foram avaliados por meio de diagramas do tipo Boxplot, construídos com auxílio do software Microsoft Office Excel 2013 (Microsoft Corporation, Redmond, WA, USA).

Estatísticas descritivas de média e desvio-padrão também foram utilizados para interpretação dos dados obtidos.

Para analisar a similaridade estatística entre conjuntos de dados obtidos em diferentes fases operacionais, análises de normalidade e variância foram realizadas com o auxílio do software BioEstat ${ }^{\circledR} 5.3$ (Instituto de Desenvolvimento Sustentável Mamirauá, Tefé, AM, Brasil). Para verificação da normalidade amostral, o teste estatístico de normalidade de Lilliefors (para $k$ amostras, com alfa $=0,05$ ) foi escolhido por se destinar à análise de pequenas amostras com quantidades variáveis de dados em cada amostra. Em seguida, procedeu-se à análise de variância pelo teste $F$ (ANOVA) de um critério com teste de Tukey $(t$ 
de Student). Caso o conjunto de dados analisados não apresentasse distribuição normal, o teste de hipótese Kruskal-Walis seria aplicado. Todos os testes estatísticos foram efetuados utilizando-se um nível de significância de 5\%. 


\section{RESULTADOS E DISCUSSÃO}

\subsection{ETAPA 1: Desempenho geral do DFSBR}

Durante a ETAPA 1 foi avaliado o potencial do DFSBR no tratamento de uma água residuária sintética simulando a mistura de DAM com vinhaça em relação DQO/sulfato $=2,0$ e submetido à carga de ferro afluente crescente visando à precipitação e separação de metais (Objetivo específico 1: Sub-hipóteses 1A e 1B).

\subsubsection{Remoção de matéria orgânica e sulfato}

A Figura 5.1 apresenta o desempenho do reator DFSBR na remoção de matéria orgânica e sulfato ao longo da partida (FASE 0) e das 5 fases operacionais da ETAPA 1.

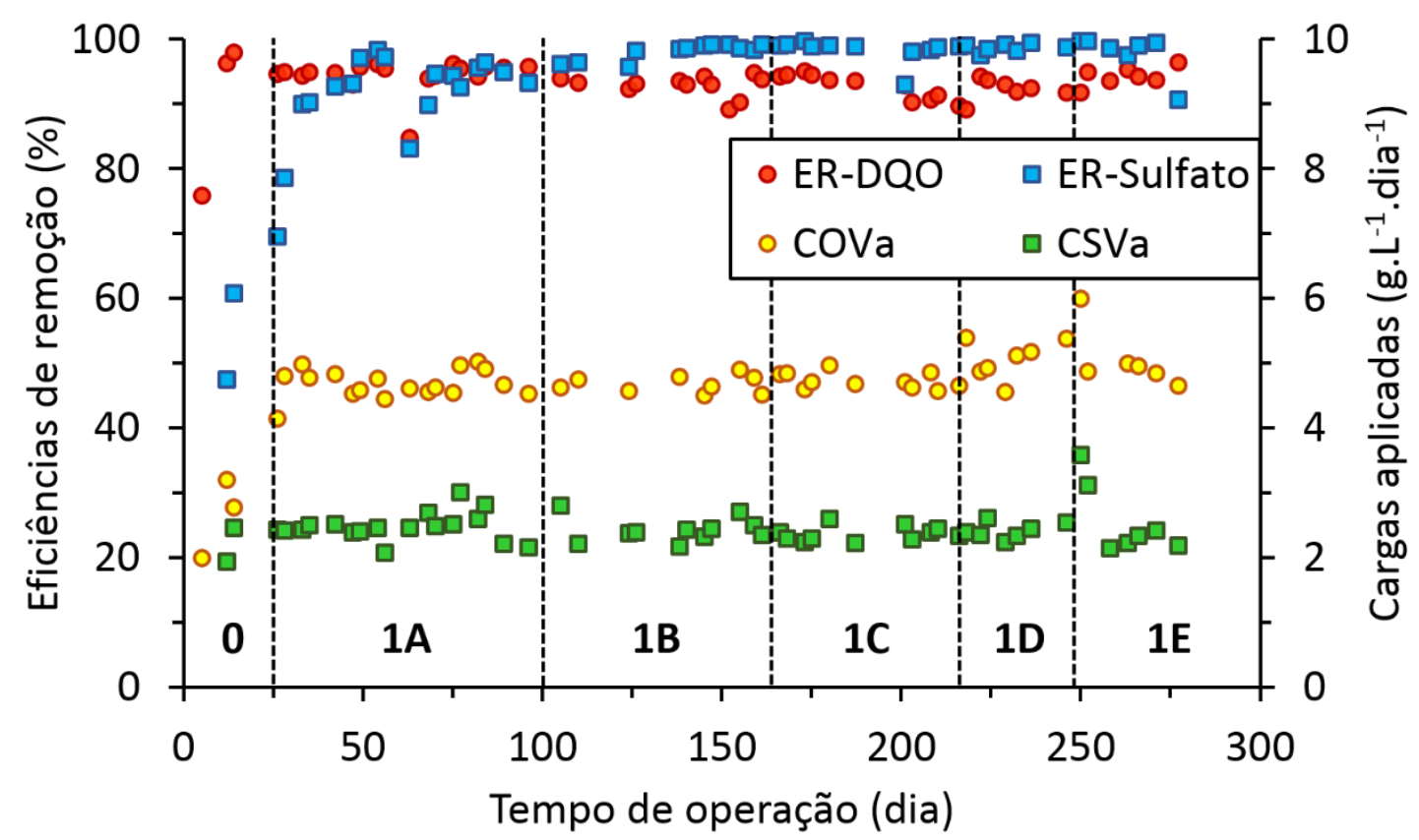

Figura 5.1: Eficiências de remoção de DQO (ER-DQO) e sulfato (ER-Sulfato), e cargas volumétricas aplicadas de DQO (COVa) e sulfato (CSVa) ao longo da ETAPA 1, operada com as seguintes concentrações de ferro: FASE 1A - 2 mg.L $^{-1}$; FASE $1 B-55$ mg. $^{-1}$; FASE 1C 110 mg.L ${ }^{-1}$; FASE 1D - 220 mg.L ${ }^{-1}$ e FASE 1E - 400 mg.L.$^{-1}$.

Fonte: $\mathrm{O}$ autor. 
Após 7 dias em reciclo fechado, o sistema foi aberto para operar em fluxo contínuo e submetido a cargas orgânicas aplicadas (COVa) crescentes, até se atingir a carga desejada de 4,7 \pm 0,2 gDQO. $\mathrm{L}^{-1} \cdot \mathrm{d}^{-1}$. Durante a fase de partida (FASE 0) a concentração de matéria orgânica afluente variou de 1700 para 4000 mgDQO.L ${ }^{-1}$. Desde o início da operação o sistema recebeu dosagem de sulfato próxima de $2000 \mathrm{mgSO}_{4}{ }^{2-} \cdot \mathrm{L}^{-1}$ para a manutenção de uma carga de sulfato aplicada (CSVa) de 2,4 $\pm 0,2 \mathrm{~g} \cdot \mathrm{L}^{-1} \cdot \mathrm{d}^{-1}$. A relação DQO/sulfato durante a inoculação e o início da fase de partida do reator (FASE 0) foi mantida em torno de 1,0, sendo aumentada gradativamente para 2,0 ao longo dos 25 dias de duração dessa fase. O início da partida do sistema em relação DQO/sulfato de 1,0 foi efetuada para se promover uma pressão de seleção favorável ao enriquecimento dos microrganismos redutores de sulfato oriundos do inóculo. Durante a FASE 0 as eficiências de remoção de sulfato aumentaram de 50\% para $80 \%$, indicando o potencial sulfetogênico da biomassa, capaz de viabilizar o estabelecimento de redução de sulfato em um curto período de tempo. Após 15 dias de operação o reator apresentou eficiências de remoção de DQO superiores a 93\% graças ao rápido estabelecimento da metanogênese. Após a fase de partida (FASE 0), já nos primeiros 5 dias de operação da FASE 1A, o sistema foi capaz de atingir eficiências de remoção de sulfato superiores a 90\%, o que indicou o sucesso no estabelecimento da sulfetogênese associada à metanogênese no reator.

A Figura 5.2 apresenta a análise estatística de Boxplot das cargas de DQO e sulfato removidas ao longo das fases operacionais testada na ETAPA 1. 
(a)

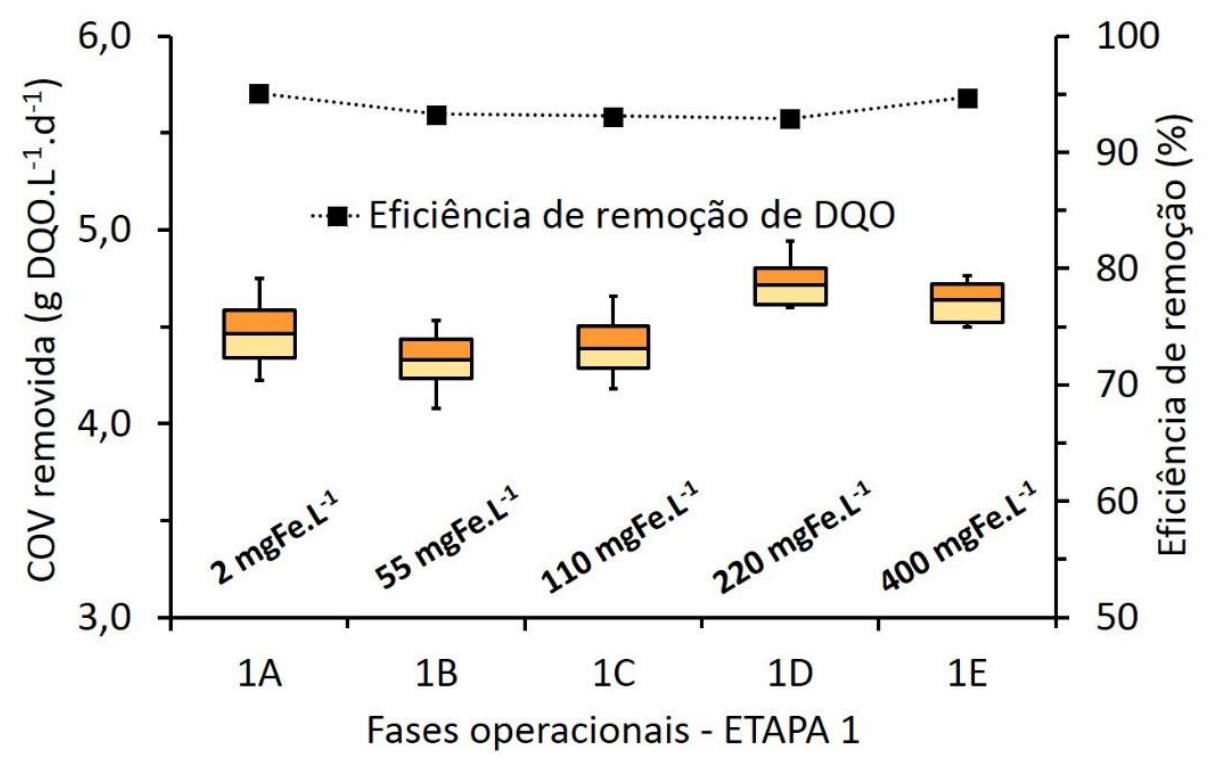

(b)

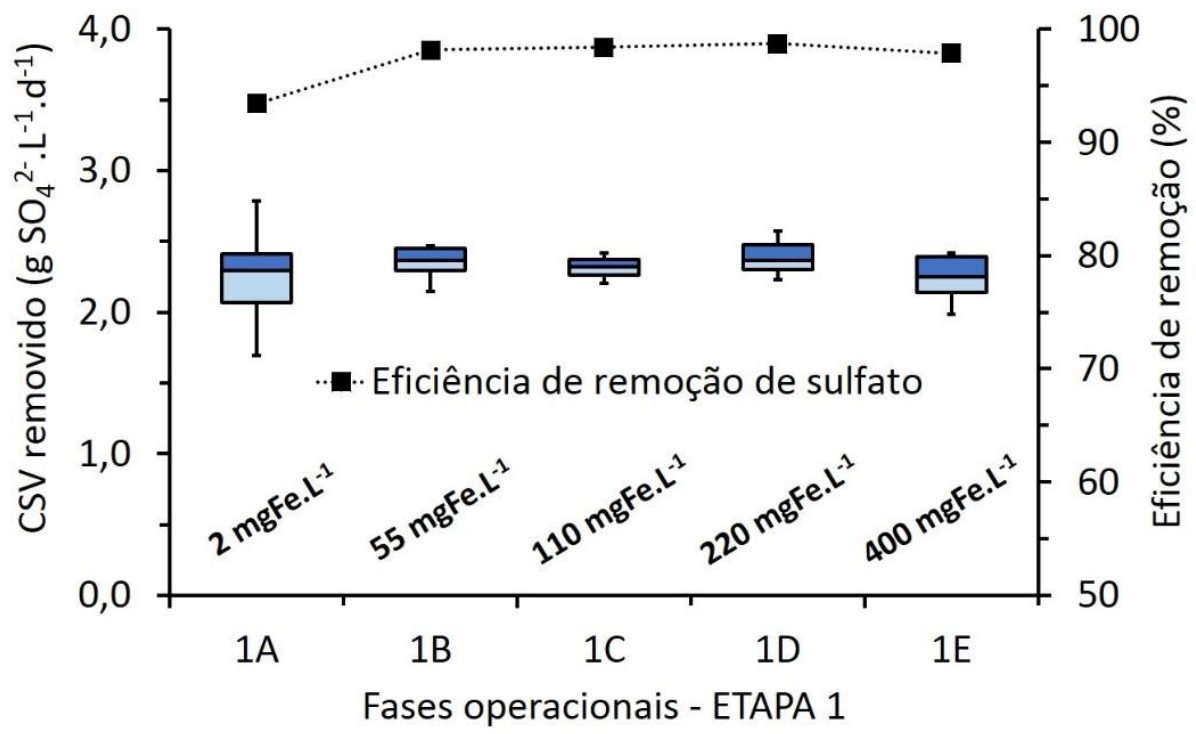

Figura 5.2. Desempenho geral do DFSBR: (a) Análise estatística de Boxplot das cargas orgânicas removidas (COVr) e eficiências médias de remoção de DQO durante a ETAPA 1; e (b) Análise estatística de Boxplot das cargas de sulfato removidas (CSVr) e eficiências médias de remoção de sulfato durante a ETAPA 1.

Fonte: GODOI et al., 2017a.

Ao longo das FASES 1A a 1E o reator DFSBR apresentou estabilidade, com eficiência média de remoção de DQO de $94 \pm 2 \%$. Carga orgânica removida de 4,4 $\pm 0,2$ gDQO.L ${ }^{-1} \cdot \mathrm{d}^{-1}$ foi obtida durante as FASES 1A, 1B e 1C. Um incremento na concentração de matéria 
orgânica afluente durante as FASES 1D e $1 \mathrm{E}\left(\mathrm{COVa}=5,1 \pm 0,4 \mathrm{gDQO} \cdot \mathrm{L}^{-1} \cdot \mathrm{d}^{-1}\right)$ promoveu o aumento da COVr para 4,7 $\pm 0,4$ gDQO.L ${ }^{-1} \cdot d^{-1}$ (Figura 5.2.a).

Eficiência de remoção de sulfato de $93 \pm 5 \%$ foi obtida ao longo da FASE 1A, operada com concentração afluente de ferro da ordem de $2 \mathrm{mg} \cdot \mathrm{L}^{-1}$. Após a introdução da DAM sintética (FASES 1B a 1E), nas quais maiores concentrações de ferro foram introduzidas no sistema (cerca de 50 até $400 \mathrm{mg} . \mathrm{L}^{-1}$ ), o reator apresentou eficiências de remoção de sulfato próximas a 100\% (Figura 5.2), ou seja, concentração efluente de sulfato abaixo do limite de detecção (LD) do método empregado $\left(2 \mathrm{mg} \cdot \mathrm{L}^{-1}\right)$. Esse resultado indicou a plena adaptação dos microrganismos sulfetogênicos às condições operacionais do sistema. Diferenças estatísticas significativas $(\mathrm{p}<0,05)$ só foram observadas entre a FASE 1A e as demais fases operacionais dessa etapa, o que confirmou o incremento real nas eficiências de remoção de sulfato obtidas pelo DFSBR após a introdução da DAM sintética. Como será mais amplamente discutido ao longo da subseção 5.1.2, p. 115, esse resultado foi atribuído à remoção do sulfeto da fase líquida pela precipitação com o ferro introduzido no reator. A minimização da concentração de $\mathrm{H}_{2} \mathrm{~S}$ dissolvido, por sua vez, levou à diminuição dos seus efeitos tóxicos sobre a biomassa sulfetogênica (BIJMANS et al., 2008; REIS et al., 1992), favorecendo o desempenho do sistema.

A Tabela 5.1 apresenta os valores médios e os desvios-padrões referentes às cargas de matéria orgânica e sulfato aplicadas e removidas, bem como as eficiências de remoção de DQO e sulfato em cada fase operacional testada ao longo da ETAPA 1. 
Tabela 5.1. Cargas orgânicas volumétricas aplicadas (COVa) e removidas (COVr), cargas de sulfato volumétricas aplicadas (CSVa) e removidas (CSVr) e eficiências de remoção de DQO (ER-DQO) e sulfato (ER-Sulfato) obtidas durante a ETAPA 1.

\begin{tabular}{ccccccc}
\hline FASES & $\begin{array}{c}\text { COVa } \\
\left(\mathbf{g D Q O} . \mathbf{L}^{\mathbf{- 1}} \cdot \mathbf{d}^{\mathbf{- 1}}\right)\end{array}$ & $\begin{array}{c}\text { ER-DQO } \\
(\boldsymbol{\%})\end{array}$ & $\begin{array}{c}\text { CSVa } \\
\left(\mathbf{g S O}_{4}{ }^{2-} \cdot \mathbf{L}^{-\mathbf{1}} \cdot \mathbf{d}^{\mathbf{- 1}}\right)\end{array}$ & $\begin{array}{c}\text { ER-Sulfato } \\
(\boldsymbol{\%})\end{array}$ \\
\hline 1A & $4,7 \pm 0,2$ & $4,5 \pm 0,2$ & $94 \pm 3$ & $2,5 \pm 0,2$ & $2,3 \pm 0,3$ & $93 \pm 4$ \\
1B & $4,6 \pm 0,2$ & $4,3 \pm 0,1$ & $93 \pm 2$ & $2,4 \pm 0,2$ & $2,4 \pm 0,2$ & $98 \pm 1$ \\
1C & $4,7 \pm 0,1$ & $4,4 \pm 0,2$ & $93 \pm 2$ & $2,4 \pm 0,1$ & $2,3 \pm 0,1$ & $98 \pm 2$ \\
1D & $5,1 \pm 0,3$ & $4,7 \pm 0,2$ & $92 \pm 2$ & $2,4 \pm 0,1$ & $2,4 \pm 0,1$ & $99 \pm 1$ \\
1E & $4,9 \pm 0,6$ & $4,6 \pm 0,5$ & $94 \pm 1$ & $2,6 \pm 0,6$ & $2,4 \pm 0,4$ & $98 \pm 3$ \\
\hline
\end{tabular}

Fonte: $\mathrm{O}$ autor.

As altas eficiências de remoção de DQO obtidas pelo reator durante toda a ETAPA 1 podem ser explicadas pela relação DQO/sulfato próxima de 2,0, mantida ao longo de todo período operacional. Pelo fato dessa relação ser maior que a estequiométrica de 0,67 (LENS et al., 1998), possibilitou-se o estabelecimento da metanogênese concomitante com a redução de sulfato. Assim, enquanto uma parcela da matéria orgânica disponível foi utilizada como doador de elétrons para a redução de sulfato, a DQO restante foi convertida a metano (GODOI et al., 2015; DAMIANOVIC; FORESTI, 2009; CHOI; RIM, 1991).

Conforme descrito anteriormente, na subseção 4.13.1, p. 96, foram efetuados os cálculos para determinação da contribuição da sulfetogênese e metanogênese na remoção global de matéria orgânica do reator. O gráfico apresentado na Figura 5.3 detalha a distribuição do fluxo de elétrons partilhado entre as vias de remoção da DQO estabelecidas no DFSBR. 


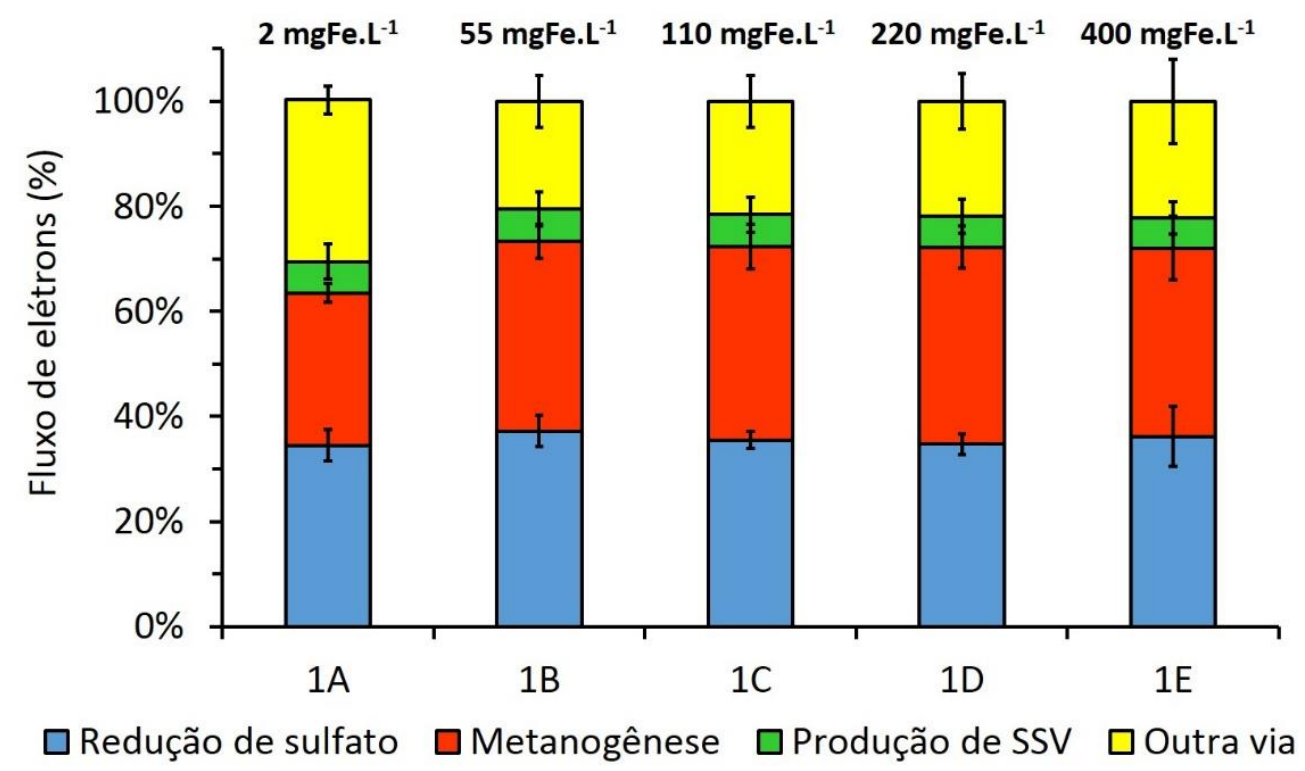

Figura 5.3. Distribuição do fluxo de elétrons no DFSBR (em porcentagem de DQO) para as vias de redução de sulfato, metanogênese e produção de sólidos suspensos voláteis (SSV) em cada fase da ETAPA 1. As barras de erros representam o desvio-padrão.

Fonte: GODOI et al., 2017a.

Em todas as fases operacionais da ETAPA 1 a sulfetogênese foi responsável pela oxidação de 35 - 37\% da DQO removida no DFSBR. Resultado semelhante foi reportado por VILELA et al. (2014), o qual operou reator anaeróbio horizontal de leito fixo (RAHLF) alimentado com etanol sob relação DQO/sulfato de 1,9. No referido estudo, a contribuição da sulfetogênese para o processo global de remoção de matéria orgânica foi da ordem de 33\%.

Já a metanogênese, constituindo uma via complementar de remoção de matéria orgânica, foi responsável por 29 - 38\% da DQO removida. Em torno de 6\% de DQO removida foi atribuída à produção de sólidos suspensos voláteis (SSV), os quais foram liberados no efluente do reator (cerca de $200 \mathrm{mgSSV}^{-1}$ ou $284 \mathrm{mgDQO} . \mathrm{L}^{-1}$ ), sendo possivelmente constituídos de biomassa desprendida do material suporte ou polímeros extracelulares.

A fração restante de DQO removida, principalmente durante a FASE 1A (37\%), foi parcialmente atribuída à assimilação de matéria orgânica para síntese celular (MICHAUD et 
al., 2002). De fato, as forças de cisalhamento resultantes da velocidade superficial proporcionada pela alta razão de recirculação $\left(\mathrm{V}_{\mathrm{S}}=3,50 \mathrm{~m} \cdot \mathrm{h}^{-1}\right)$ aplicada durante a ETAPA 1 podem ter intensificado o desprendimento do biofilme, exigindo maior consumo de matéria orgânica para crescimento celular, de forma a substituir a biomassa perdida (MICHAUD et al., 2003). Nesse caso, embora os resultados de SSV determinados no efluente do reator estejam abaixo do esperado, uma parcela do material em suspensão pode ter se acumulado juntamente com os sulfetos metálicos, na zona de sedimentação do reator, impedindo a sua quantificação no efluente.

Uma outra hipótese para a presente observação seria a perda de quantias consideráveis de metano dissolvido com o efluente do reator (PAUSS et al., 1990). De fato, GIMÉNEZ et al. (2012) mostraram que cerca de 40\% do metano total produzido em um reator anaeróbio de membrana submersa tratando efluente rico em sulfato foi encontrado sob a forma dissolvida no meio líquido. Essas perdas de metano não puderam ser diretamente quantificadas durante o presente estudo, o que pode ter prejudicado o balanço de massa apresentado. Nesse caso, a participação da metanogênese para o processo global de remoção de DQO seria maior que o estimado.

Vale ressaltar também que durante a FASE 1A os microrganismos estiveram expostos a maiores concentrações de sulfeto total dissolvido (STD) e sulfeto molecular $\left(\mathrm{H}_{2} \mathrm{~S}\right)$, como será mostrado mais adiante (subseção 5.1.2, p. 115). O stress da biomassa sob essas condições pode ter favorecido um maior desvio do fluxo de elétrons para a manutenção do biofilme (MOUNFORT; ASHER, 1979).

Por outro lado, o estabelecimento da associação entre BRS com AM deve ser apontado como um fator chave para o sucesso do processo de tratamento de águas residuárias ricas em sulfato (GODOI et al., 2015). De fato, relações DQO/sulfato acima da estequiométrica 
favorecem o estabelecimento de BRS oxidadoras incompletas da matéria orgânica (DAMIANOVIC; FORESTI, 2007). Nesse caso o sulfato é reduzido a sulfeto enquanto a matéria orgânica é oxidada a acetato, o qual passa a ser utilizado como substrato, principalmente, pelas AM acetoclásticas.

Em função de seu lento crescimento, principalmente quando presentes em número reduzido no inóculo (DAMIANOVIC; FORESTI, 2009; OMIL et al., 1998), bactérias redutoras de sulfato oxidadoras do acetato são de difícil estabelecimento em reatores anaeróbios (CAO et al., 2012; LENS et al., 2002). Dessa forma, reatores exclusivamente sulfetogênicos tendem a apresentar acúmulo pronunciado de ácido acético no efluente (VELASCO et al., 2008; NAGPAL et al., 2000; REIS et al., 1992), uma vez que as reações de oxidação parcial da matéria orgânica via redução de sulfato independem da pressão parcial do hidrogênio (HULSHOFF POL et al., 1998).

GALLEGOS-GARCIA et al. (2009), por exemplo, obtiveram baixa eficiência de remoção de DQO (54\%) e considerável acúmulo de ácido acético (> $1000 \mathrm{mg} . \mathrm{L}^{-1}$ ) em reator de leito fluidizado inverso tratando água residuária rica em metais $(\mathrm{TDH}=24 \mathrm{~h}$; $\left.\mathrm{DQO}_{\mathrm{AFLUENTE}}=2500 \mathrm{mg} \cdot \mathrm{L}^{-1}\right)$. A baixa relação DQO/SO ${ }_{4}{ }^{2-}$ aplicada no referido estudo $(0,8)$ deve ter contribuído também para a baixa eficiência de remoção de sulfato observada (41\%), pela incapacidade das BRS presentes no reator em utilizarem o acetato produzido como doador de elétrons.

No presente estudo, o ácido acético foi o principal componente da matéria orgânica residual no efluente do reator DFSBR, enquanto outros ácidos orgânicos estiveram praticamente ausentes (abaixo de $15 \mathrm{mg} . \mathrm{L}^{-1}$ ), o que indicou a atuação de BRS oxidadoras incompletas. Acompanhando o incremento nas eficiências de remoção de sulfato (Figura 
5.2.b), as concentrações de ácido acético remanescente também aumentaram ao longo das FASES 1A a 1D, como mostrado na Figura 5.4.

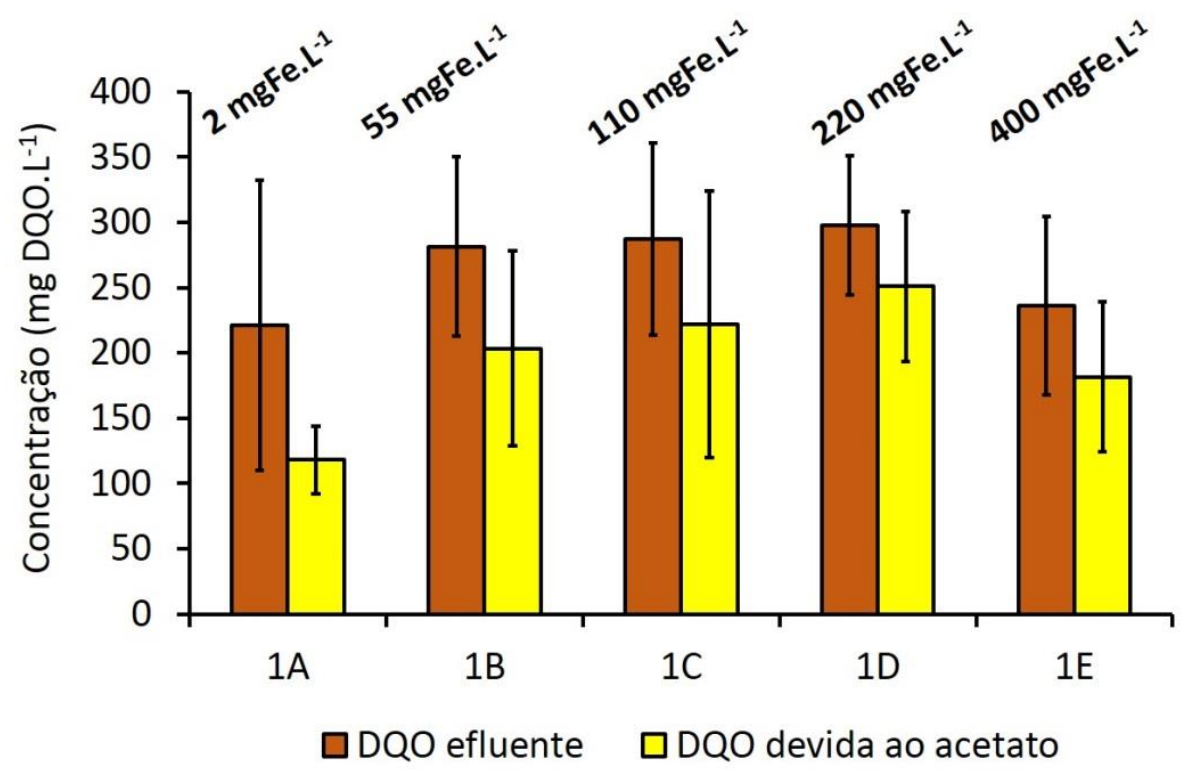

Figura 5.4. Concentrações de ácido acético (em termos de DQO) no efluente do reator DFSBR durante as fases operacionais da ETAPA 1. As barras de erro representam o desvio-padrão.

Fonte: GODOI et al., 2017a.

Enquanto a concentração de ácido acético no efluente durante a FASE 1A foi mantida próxima de $120 \mathrm{mgDQO} . \mathrm{L}^{-1}$, logo após o início da adição da DAM sintética (FASE 1B) essa concentração aumentou até atingir um pico de 360 mgDQO. $\mathrm{L}^{-1}$, diminuindo em seguida. Nessa fase a produção média de ácido acético foi da ordem de $200 \mathrm{mgDQO} . \mathrm{L}^{-1}$. Esse poderia ser um indicativo de que a dosagem de ferro $\left(55 \mathrm{mgFe}^{2+} \cdot \mathrm{L}^{-1}\right)$ teria afetado o desempenho da metanogênese acetoclástica, uma vez que as eficiências de redução de sulfato não foram prejudicadas (Figura 5.1). Todavia, como será discutido na subseção 5.1.3, p. 126, a produção de metano tampouco foi prejudicada, mas estimulada. De fato, concentrações de ferro ferroso $\left(\mathrm{Fe}^{2+}\right)$ próximas de até $450 \mathrm{mg} \cdot \mathrm{L}^{-1}$ não se mostraram tóxicas ou inibitórias para a atividade de microrganismos metanogênicos (MUDHOO; KUMAR, 2013) ou redutores de sulfato 
(TABAK et al., 2004). Pelo contrário, a precipitação de sulfetos metálicos proporcionada pela adição de ferro no sistema é fator benéfico por limitar as concentrações de sulfeto no meio líquido, de modo a evitar seus efeitos deletérios tanto sobre os microrganismos metanogênicos (O’FLAHERTY et al., 1998; HILTON; OLESZKIEWICZ, 1988; KOSTER et al., 1986) quanto redutores de sulfato (REIS et al., 1992; MCCARTNEY; OLESZKIEWICZ, 1991). Assim, a hipótese levantada é a de que o aumento no metabolismo das BRS, indicado pelo aumento nas eficiências de remoção de sulfato (Figura 5.2), foi responsável pela maior produção desse intermediário.

Após a diminuição nas concentrações efluentes de ácido acético, a FASE 1C foi iniciada, com o aumento na dosagem de ferro para cerca de $110 \mathrm{mgFe}^{2+} \cdot \mathrm{L}^{-1}$. Durante a FASE 1C foi observada uma concentração média de ácido acético no efluente próxima de 220 mgDQO.L $\mathrm{L}^{-1}$. Já a média desse intermediário ao longo da FASE 1D foi de $250 \mathrm{mgDQO} . \mathrm{L}^{-1}$. Durante a última fase operacional da ETAPA 1, por sua vez, o ácido acético remanescente no efluente decresceu, atingindo uma média de $180 \mathrm{mg} . \mathrm{L}^{-1}$. Vale ressaltar que as concentrações de ácido acético foram transformadas em termos de DQO pela aplicação do fator de conversão de 1,07 gDQO.gCH${ }_{3} \mathrm{COOH}^{-1}$.

Apesar do remanescente de ácido acético no efluente do reator DFSBR, a redução de sulfato simultânea com a metanogênese foi mantida, sem prejuízo para as eficiências de remoção de matéria orgânica e sulfato. A alcalinidade produzida pelo metabolismo das BRS foi suficiente para elevar o $\mathrm{pH}$ do meio sintético de $6,1 \pm 0,2$ no afluente para 7,2 \pm 0,2 no interior do reator, sendo em média 8,3 $\pm 0,2$ o valor do $\mathrm{pH}$ do efluente do DFSBR durante todo o período operacional da ETAPA 1. Durante a FASE 1A, sem complementação de cloreto ferroso, a alcalinidade total no efluente foi da ordem de $2500 \mathrm{mgCaCO}_{3} \cdot \mathrm{L}^{-1}$. Com o aumento na carga de ferro aplicada, a alcalinidade do sistema caiu gradativamente de 1900 
mgCaCO $3 . \mathrm{L}^{-1}$ (durante a FASE 1B) para $900 \mathrm{mgCaCO}_{3} \cdot \mathrm{L}^{-1}$ (FASE 1E) como consequência da produção de acidez $\left(\mathrm{H}^{+}\right)$durante a formação de sulfetos metálicos (Equação (3.6)). Todavia, a digestão anaeróbia permaneceu equilibrada, como indicado pela relação Ai/Ap de 0,32 $\pm 0,06$ (RIPLEY et al., 1986). As concentrações remanescentes de alcalinidade apontam também para a viabilidade da diminuição do $\mathrm{NaOH}$ dosado no afluente, conforme estudado durante a ETAPA 3, com vantagens econômicas para o processo. Esse resultado também se mostra adequado para o tratamento da mistura de DAM com vinhaça, pelo fato de ambas as águas residuárias apresentarem caráter marcadamente ácido.

Maior detalhamento a respeito do comportamento da alcalinidade no DFSBR submetido ao aumento progressivo da carga de ferro será apresentado na seção 5.2, p. 134.

\subsubsection{Produção de sulfeto e precipitação de ferro}

A Figura 5.5 apresenta as concentrações médias de sulfeto total dissolvido (STD) e as concentrações calculadas (conforme subseção 4.13.3, p. 99) de sulfeto de hidrogênio nãoionizado (sulfeto molecular $-\mathrm{H}_{2} \mathrm{~S}$ ) e do íon $\mathrm{HS}^{-}$em cada fase operacional da ETAPA 1. 


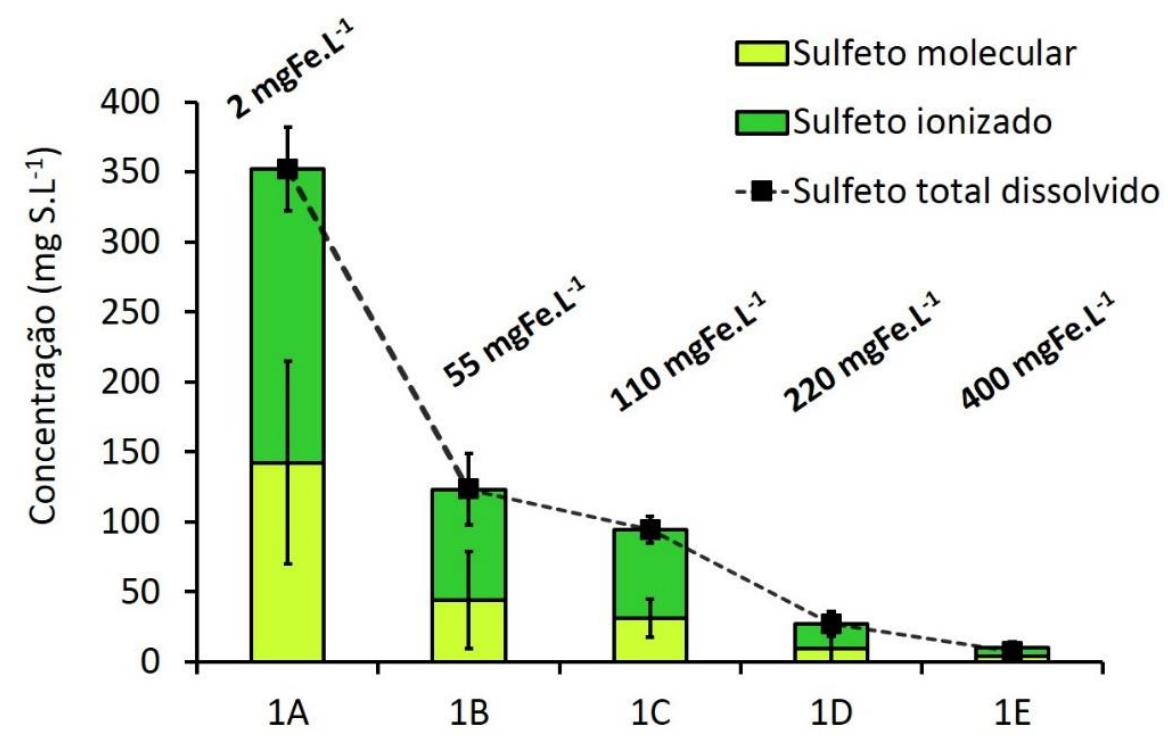

Figura 5.5. Concentrações de sulfeto total dissolvido, sulfeto de hidrogênio molecular $\left(\mathrm{H}_{2} \mathrm{~S}\right)$ e sulfeto ionizado (HS) no efluente do reator DFSBR durante a ETAPA 1. As barras de erros representam o desvio-padrão.

Fonte: GODOI et al., 2017a.

Durante a FASE 1A, operada com adição mínima de cloreto ferroso no afluente, a concentração média de sulfeto total dissolvido (STD) foi de $352 \pm 66 \mathrm{mgS} . \mathrm{L}^{-1}$. Pelos cálculos de especiação do sulfeto em fase líquida estimou-se uma concentração de sulfeto molecular da ordem de $142 \mathrm{mgS} . \mathrm{L}^{-1}$. As concentrações de sulfeto ao longo da primeira fase operacional permaneceram próximas dos limites de toxicidade apontados como críticos pela literatura. De acordo com MAILLACHERUVU et al. (1993) problemas com inibição por sulfeto total dissolvido (STD) e pelo $\mathrm{H}_{2} \mathrm{~S}$ não dissociado se dão em reatores de biomassa imobilizada em leito fixo a partir de $400 \mathrm{mgSTD} . \mathrm{L}^{-1}$ e $125 \mathrm{mgH}_{2} \mathrm{~S} . \mathrm{L}^{-1}$, respectivamente. De fato, durante a FASE 1A o reator DFSBR não apresentou instabilidade nos processos de remoção de DQO e sulfato, e tampouco acúmulo pronunciado de ácidos orgânicos voláteis no efluente. Ainda assim, o desempenho do sistema foi favorecido nas fases subsequentes, com diminuição da concentração de sulfeto disponível na fase líquida (Figura 5.1).

De fato, após a introdução da DAM sintética (solução concentrada de cloreto ferroso) 
os valores de sulfeto total dissolvido diminuíram em consequência da precipitação dos sulfetos de ferro no interior do reator. Durante a FASE 1B a concentração média de STD foi de $123 \pm 55 \mathrm{mgS} . \mathrm{L}^{-1}$. Durante as FASES 1C e 1D essa concentração caiu para $94 \pm 22$ e $27 \pm$ $20 \mathrm{mgS} . \mathrm{L}^{-1}$, respectivamente. Durante a FASE 1E, operada com a maior dosagem de ferro, as concentrações de STD caíram para níveis abaixo de $<10 \mathrm{mgS} . \mathrm{L}^{-1}$.

O sulfeto de hidrogênio liberado para a fase gasosa também foi medido, podendo-se calcular a produção total de sulfeto no reator DFSBR, conforme apresentado na Figura 5.6.

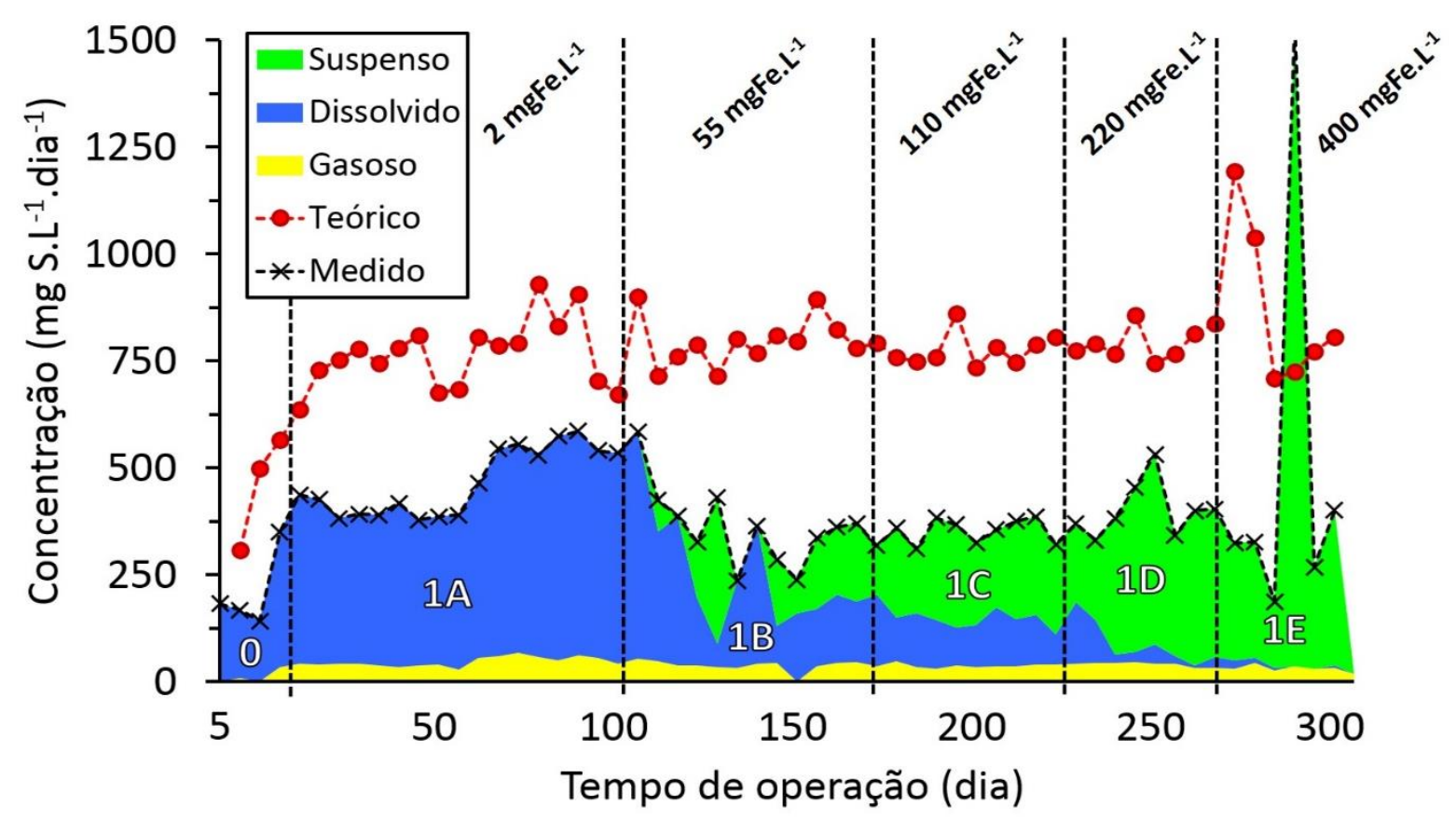

Figura 5.6: Frações de sulfeto produzidas pelo reator DFSBR ao longo da ETAPA 1.

Fonte: $\mathrm{O}$ autor.

Durante a FASE 1A obteve-se média de $61 \%$ de recuperação do sulfeto teoricamente produzido, calculado pela fração de sulfato removida e considerando-se que $1 \mathrm{mg}$ de $\mathrm{SO}_{4}{ }^{2-}$ reduzido levam à geração de $0,33 \mathrm{mg}$ de $\mathrm{S}^{2-}$ (BARRERA et al., 2014). Resultados semelhantes aos obtidos já foram relatados em estudos anteriores (GODOI, 2014; VILELA, 
2012). Uma explicação para essa observação seria a oxidação parcial do sulfeto dissolvido a compostos de enxofre com estados intermediários de oxidação. A coloração esverdeada das amostras efluentes, possível de ser visualizada ao longo da primeira fase (FASE 1A), as quais se tornavam esbranquiçadas sob titulação ácida, foi um forte indício da ocorrência de polissulfetos em suspensão coloidal (CHEN; MORRIS, 1972). Os polissulfetos são formados pela interação entre o enxofre elementar e o sulfeto de hidrogênio dissolvido, apresentando-se sob a forma $\mathrm{S}_{x}^{2-}(\operatorname{com} x$ entre 2 e 5$)$.

A ocorrência de enxofre elementar no interior do reator DFSBR foi confirmada por microscopia ótica de contraste de fase realizada em amostras de biomassa provenientes do material suporte ao final da FASE 1A, conforme mostrado na Figura 5.7. A oxidação parcial do sulfeto a enxofre elementar no interior do DFSBR poderia ter se dado de forma abiótica, a partir da entrada de oxigênio no sistema através da falha na vedação de mangueiras utilizadas na alimentação e na linha de reciclo do reator. $\mathrm{O} \mathrm{O}_{2}$ dissolvido, presente no meio sintético preparado com água de abastecimento, também pode ter sido uma das causas que possibilitaram a oxidação do sulfeto disponível na fase líquida a enxofre elementar. O metabolismo de bactérias fototróficas anoxigênicas, as quais depositam enxofre elementar no interior ou exterior de suas células (MADIGAN et al., 2000; HOLT et al., 1994), também não pode ser descartado, haja vista a identificação de morfologias semelhantes à células acumuladoras de $\mathrm{S}^{0}$ (Figura 5.8) 


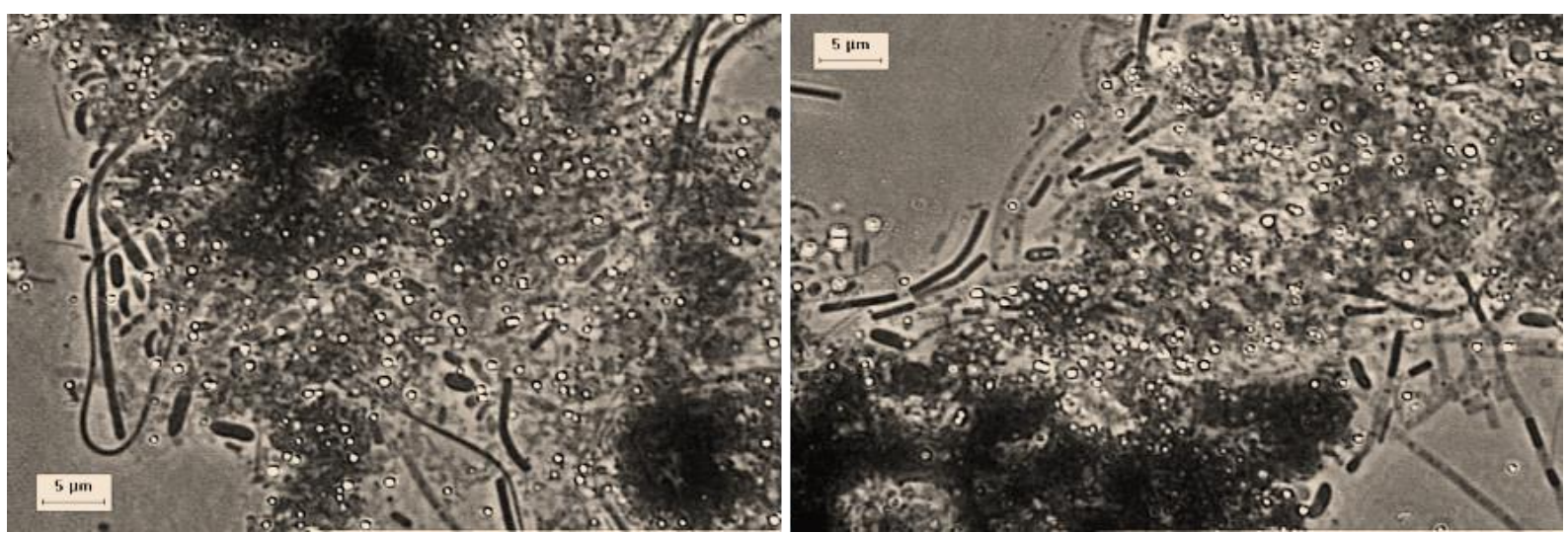

Figura 5.7. Pontos brancos são indícios de enxofre elementar acumulado em amostras de biomassa do reator ao final da primeira fase operacional.

Fonte: $\mathrm{O}$ autor.

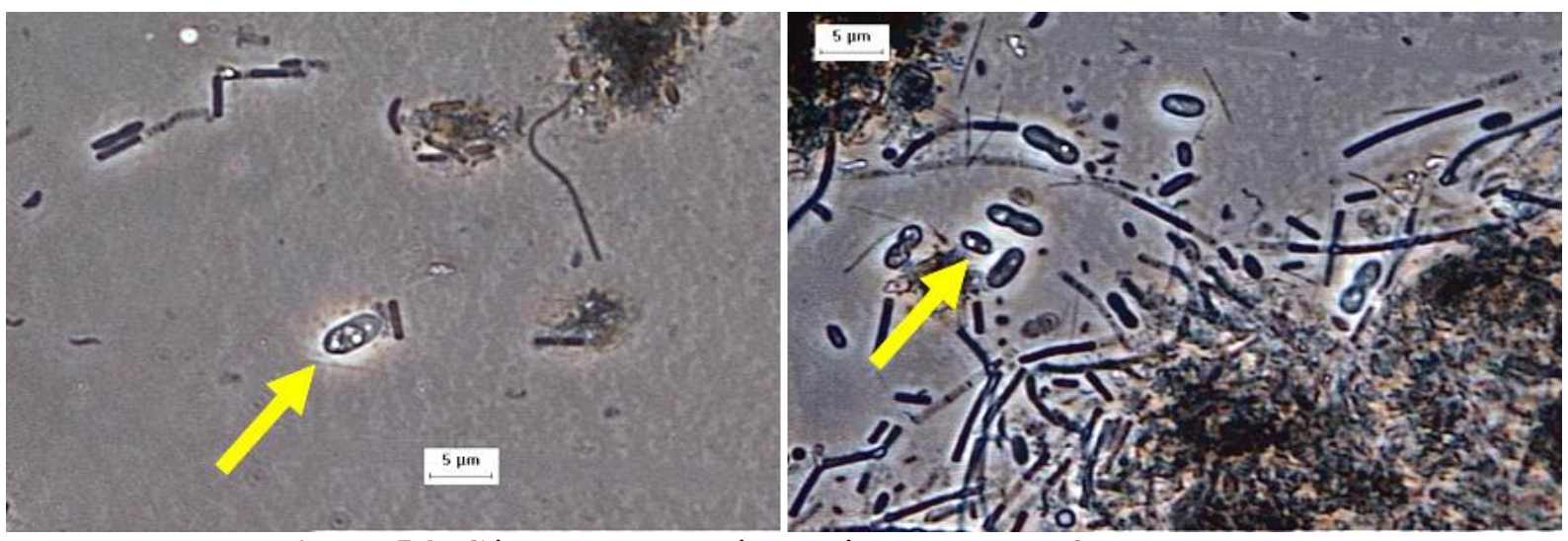

Figura 5.8. Células com possível acúmulo de enxofre elementar.

Fonte: $\mathrm{O}$ autor.

A presença de oxigênio no sistema, indicado pelas observações acima mencionadas, pode ter alterado também o balanço de matéria orgânica consumida (fluxo de elétrons) representado na Figura 5.3. A presença de oxigênio dissolvido, além da formação de compostos de enxofre com estados intermediários de oxidação, pode resultar também na reoxidação completa do sulfeto a sulfato. Nesse caso, o sulfato formado pode ser novamente reduzido pelas BRS, com consumo de uma nova parcela de matéria orgânica, a qual, todavia, não pode ser computada. Assim, a participação da sulfetogênese na remoção global de DQO no DFSBR poderia ser ainda maior do que a que foi estimada. 
Durante as etapas com adição de ferro, as porcentagens de recuperação do sulfeto nas frações líquida e gasosa foram ainda menores (cerca de 50 -45\%), o que já era esperado em função da precipitação de sulfetos de ferro no interior do reator. Durante a FASE 1E, última fase da ETAPA 1, operada com máxima carga de ferro aplicada, um pico pontual de concentração de sulfeto em suspensão no efluente se deveu ao escape de sulfetos metálicos acumulados no sistema.

Com relação à remoção de ferro, escolhido como metal de referência no presente estudo, a Tabela 5.2 apresenta os valores médios das cargas volumétricas de ferro aplicadas (CFVa) e removidas (CFVr), bem como as eficiências de remoção de ferro total (ER-Fe) observadas durante a ETAPA 1.

Tabela 5.2. Cargas volumétricas de ferro aplicadas (CFVa) e removidas (CFVr), e eficiências de remoção de ferro total (ER-Fe) durante a ETAPA 1.

\begin{tabular}{cccc}
\hline FASES & $\begin{array}{c}\text { CFVa } \\
\left(\mathbf{g F e}^{2+} \cdot \mathbf{L}^{-\mathbf{1}} \cdot \mathbf{d}^{-\mathbf{1}}\right)\end{array}$ & $\begin{array}{c}\text { ER-Fe } \\
(\boldsymbol{\%})\end{array}$ \\
\hline 1A * & $<0,003$ & & \\
1B & $0,07 \pm 0,01$ & $0,05 \pm 0,01$ & $85 \pm 9$ \\
1C & $0,13 \pm 0,01$ & $0,11 \pm 0,01$ & $83 \pm 5$ \\
1D & $0,26 \pm 0,02$ & $0,21 \pm 0,02$ & $81 \pm 7$ \\
1E & $0,51+0,06$ & $0,45 \pm 0,07$ & $95 \pm 6$ \\
\hline
\end{tabular}

*Durante a FASE 1A não foi realizado o monitoramento da remoção de ferro, visto que esse metal foi adicionado em concentrações traço, exclusivamente como nutriente para a biomassa.

Fonte: $\mathrm{O}$ autor.

O reator DFSBR apresentou eficiência média de remoção de ferro de $82 \pm 9 \%$ durante as FASES 1B, 1C e 1D, nas quais foram utilizadas concentrações de ferro afluente igual a 55 $\pm 5,110 \pm 10$ e $220 \pm 15 \mathrm{mgFe}^{2+} \cdot \mathrm{L}^{-1}$, respectivamente. No caso da FASE $1 \mathrm{E}$, em que a maior 
concentração de ferro testada foi de $400 \pm 70 \mathrm{mgFe}{ }^{2+} \cdot \mathrm{L}^{-1}$, a eficiência de remoção de ferro foi de $95 \pm 6 \%$ (Figura 5.9.a). Apesar das eficiências de remoção semelhantes durante as FASES 1B a 1D, o reator apresentou cargas de ferro removidas crescentes, acompanhando o aumento gradual na carga de ferro aplicada, conforme mostrado no gráfico da Figura 5.9b.

(a)

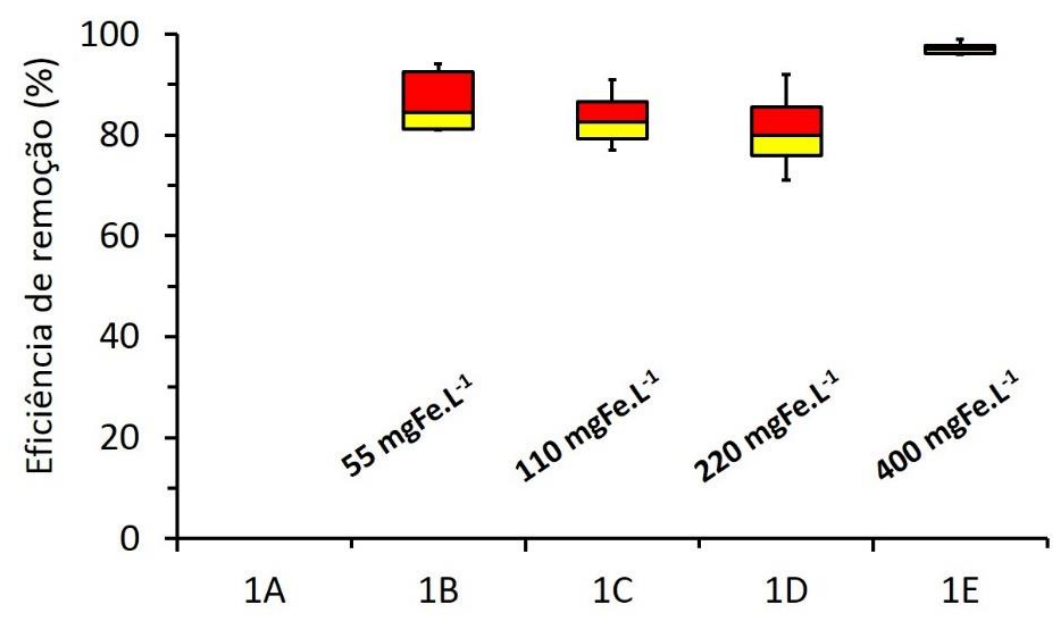

(b)

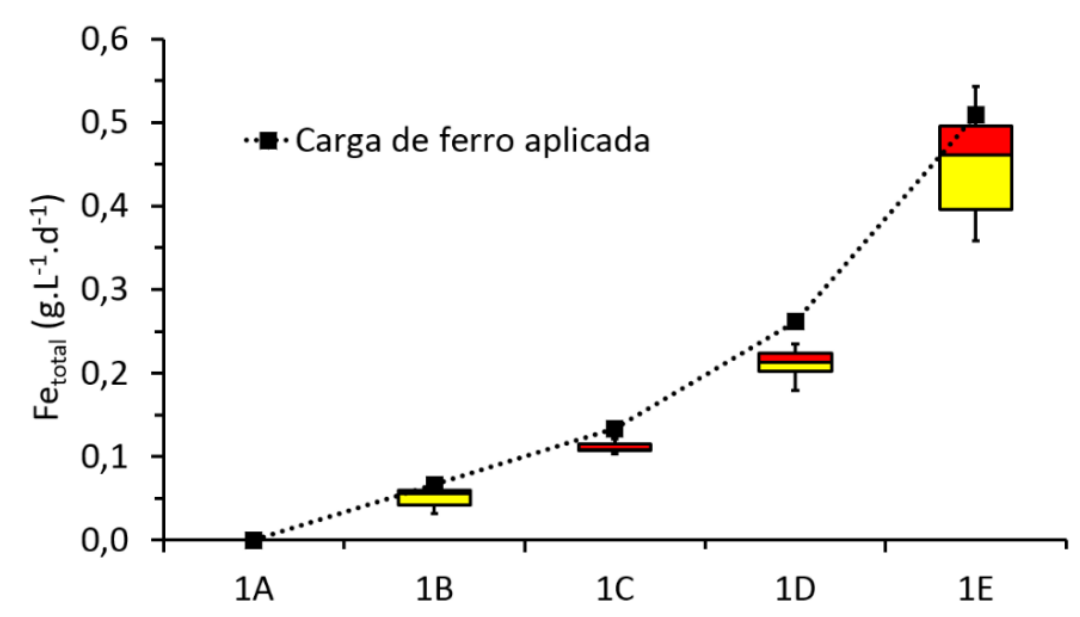

Figura 5.9. Desempenho do DFSBR na remoção de ferro: (a) Análise estatística de Boxplot das eficiências de remoção de ferro obtidas nas FASES 1B a 1E; e (b) Análise estatística de Boxplot das cargas de ferro removidas e cargas de ferro médias aplicadas durante a ETAPA 1.

Fonte: GODOI et al., 2017a.

O desempenho do DFSBR alcançada durante as FASES 1B a 1D foi inferior ao 
usualmente obtido em reatores de leito fluidizado e fluxo descendente aplicados à precipitação de metais, os quais apresentam geralmente eficiências de remoção de metais da ordem de 99\% (SAHINKAYA; GUNGOR, 2010; GALLEGOS-GARCIA et al., 2009). Para explicar essa observação foi levantada a hipótese de que o volume da câmara de sedimentação na zona inferior do reator constituiria um fator limitante do processo, uma vez que a realização de descartes de fundo esporádicos melhoravam o desempenho do sistema com relação à remoção de ferro (Figura 5.10). De fato, o acúmulo de sulfetos metálicos poderia atingir a saturação na zona de sedimentação, com ocorrência do aumento nas concentrações do ferro efluente, uma vez que os sulfetos de ferro seriam arrastados para fora do reator.

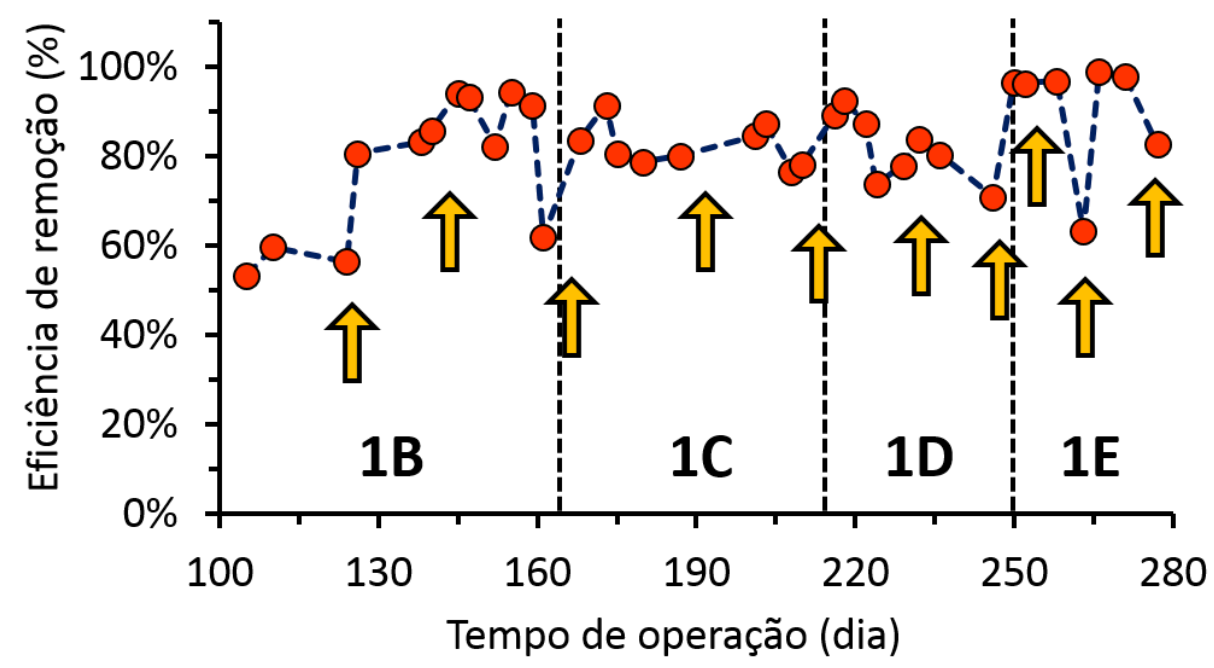

Figura 5.10. Monitoramento temporal das eficiências de remoção de ferro ao longo da ETAPA 1. Setas em destaque indicam realização de descartes de fundo no DFSBR.

Fonte: $\mathrm{O}$ autor.

Durante as FASES 1A a 1D a frequência do descarte variou de mensal a quinzenal. Em cada descarte, $500 \mathrm{~mL}$ do lodo rico em sulfetos metálicos era coletado, conforme anteriormente descrito (seção 4.3, p. 64). Como já indicado, sempre que o descarte era realizado, o reator apresentava eficiência de remoção similar ou superior à alcançada 
anteriormente ao descarte. Como estratégia para melhorar a retenção e recuperação de sulfetos metálicos no DFSBR, a frequência de descartes passou a ser realizada semanalmente durante a operação da FASE 1E. O aumento na frequência de coleta do material precipitado favoreceu a remoção de ferro no DFSBR, com eficiências que passaram de cerca de 83\% (FASES 1B a 1D) para próximo de 96\% (FASE 1E). Menor dispersão nos dados de eficiência de remoção de ferro também foram notados na FASE 1E (Figura 5.9.b), indicando uma maior estabilidade no processo de precipitação e separação dos sulfetos metálicos no interior do reator.

As análises gravimétricas de sólidos totais, fixos e voláteis de amostras de descartes de fundo do DFSBR em cada fase operacional da ETAPA 1 estão resumidas na Figura 5.11, bem como a caracterização elementar do resíduo da calcinação das mesmas amostras. 
(a)

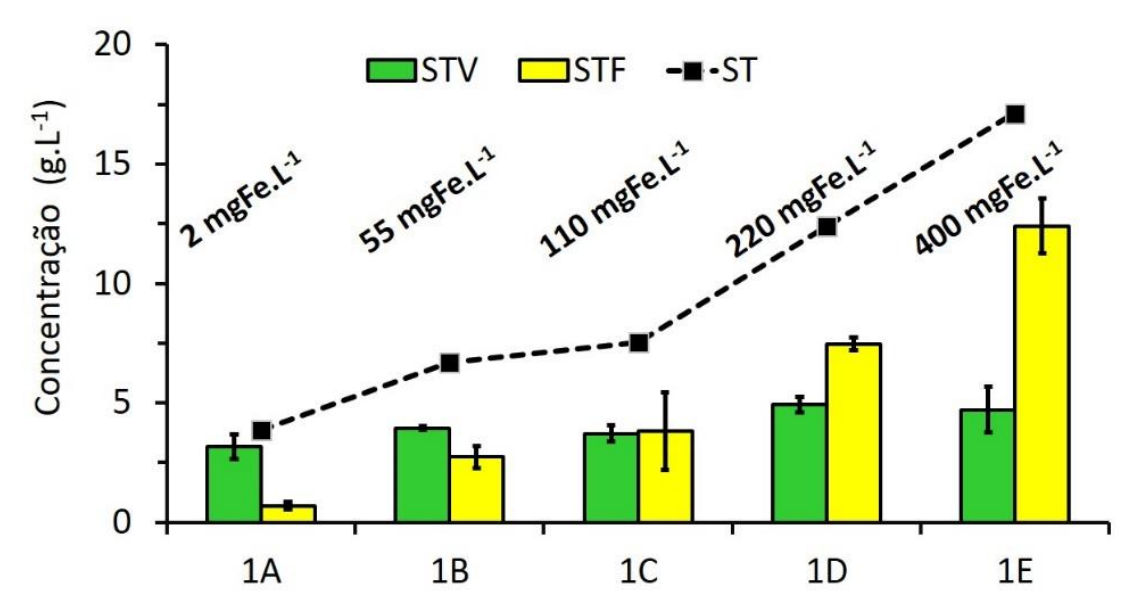

(b)

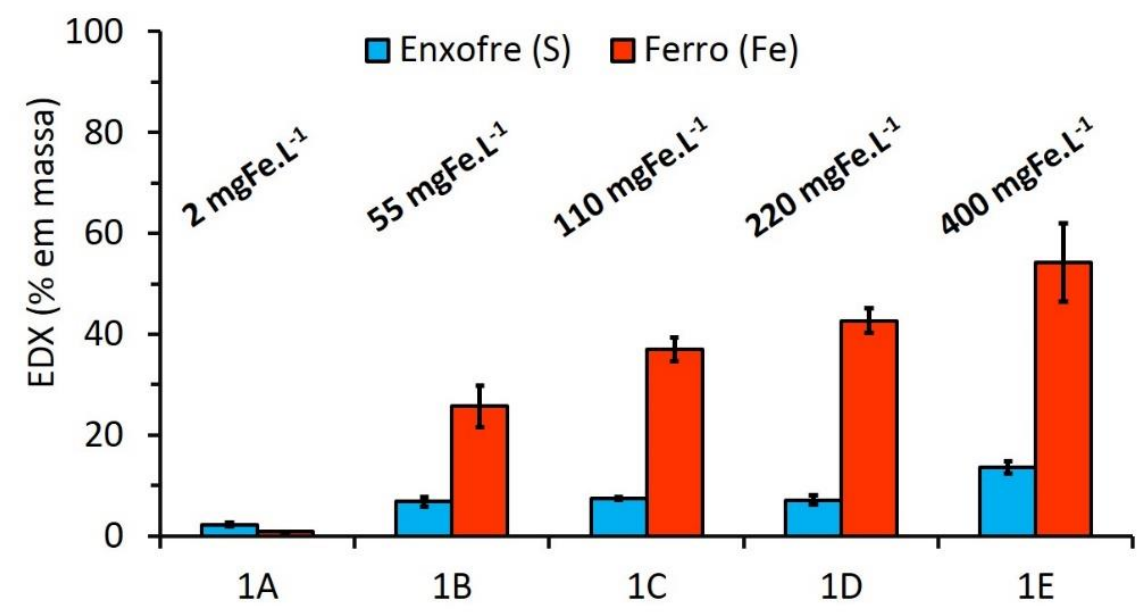

Figura 5.11. Análise do material precipitado: (a) Concentrações de sólidos totais, fixos e voláteis nas amostras de descarte em cada fase da ETAPA 1; e (b) Caracterização elementar por EDX das cinzas do material coletado. As barras de erro representam o desvio-padrão.

Fonte: GODOI et al., 2017a.

Durante as FASES 1A a 1E a concentração de sólidos totais voláteis (STV) no precipitado coletado da zona de sedimentação do DFSBR foi da ordem de 4 g.L L $^{-1}$ (Figura 5.11.a), o que fortalece a hipótese da alta síntese celular associada ao cisalhamento promovido pelas velocidades superficiais de escoamento sobre o material suporte, conforme discutido à partir da Figura 5.3. Já a concentração de sólidos totais fixos (SF) aumentou gradativamente, de 0,7 a 12,4 g.L $\mathrm{L}^{-1}$, acompanhando o aumento na carga de ferro aplicada. As porcentagens de 
ferro no precipitado também aumentaram com o decorrer da ETAPA 1, indicando o potencial do DFSBR para a separação e recuperação dos sulfetos metálicos produzidos no sistema.

A partir dos resultados obtidos é difícil determinar quais tipos de sulfetos de ferro foram formados nas condições proporcionadas pelo reator. De fato, o pré-tratamento das amostras de descarte coletadas para análise de EDX (calcinação à $550^{\circ} \mathrm{C}$ por $2 \mathrm{~h}$ ) para remoção do carbono, implicou também na sublimação dos compostos de enxofre, impedindo o estabelecimento de uma razão estequiométrica entre as porcentagens de ferro e enxofre obtidas (Figura 5.11.b). Entre as possíveis espécies de sulfeto de ferro tem-se o monossulfeto de ferro $(\mathrm{FeS})$, a pirita $\left(\mathrm{FeS}_{2}\right)$, o hidrogenossulfeto de ferro $\left(\mathrm{Fe}(\mathrm{HS})_{2}\right)$ e o $\mathrm{FeS}$ amorfo (LEWIS, 2010). Tanto $\mathrm{H}_{2} \mathrm{~S}$ quanto o íon $\mathrm{HS}^{-}$podem reagir com o ferro ferroso $\left(\mathrm{Fe}^{2+}\right)$ formando FeS conforme as Equações (5.1) e (5.2) (RICKARD, 1995). O FeS, por sua vez, pode reagir com o sulfeto dissolvido remanescente ou com outros compostos de enxofre em estados de oxidação intermediário, tais como enxofre elementar ou polissulfetos, formando $\mathrm{FeS}_{2}$, descrito pela Equação (5.3) (RICKARD; LUTHER, 2007).

$$
\begin{aligned}
& \mathrm{Fe}^{2+}+\mathrm{H}_{2} \mathrm{~S} \rightarrow \mathrm{FeS}_{(\mathrm{s})} \downarrow+2 \mathrm{H}^{+} \\
& \mathrm{Fe}^{2+}+2 \mathrm{HS}^{-} \rightarrow \mathrm{Fe}(\mathrm{HS})_{2(\mathrm{~s})} \rightarrow \mathrm{FeS}_{(\mathrm{s})} \downarrow+\mathrm{H}_{2} \mathrm{~S} \\
& \mathrm{FeS}+\mathrm{S}^{0} \rightarrow \mathrm{FeS}_{2} \downarrow
\end{aligned}
$$

Apesar da dificuldade em determinar os compostos de sulfeto e ferro formados, o DFSBR se mostrou uma configuração de reator promissora ao promover a precipitação de sulfetos metálicos e a separação desses compostos, originando um lodo rico em metais e passível de ser utilizado em etapas posteriores de recuperação.

Uma vez que na faixa de $\mathrm{pH}$ próxima da neutralidade a solubilidade do sulfeto de ferro 
é menor que a de outros sulfetos metálicos, tais como sulfetos de zinco, cobre, chumbo, níquel e cádmio (LEWIS, 2010), os resultados obtidos ainda sugerem a viabilidade da aplicação do reator de leito fixo-estruturado e fluxo descendente para a precipitação e recuperação de outros metais de maior interesse econômico.

\subsubsection{Produção de metano}

Em sistemas aplicados à remoção de sulfato com posterior precipitação de metais pelo sulfeto costuma-se buscar a supressão completa da metanogênese, com o estabelecimento exclusivo da sulfetogênese (LENS; KUENEM, 2001). Todavia, no caso de sistemas em que se deseja tanto a redução de sulfato como a degradação da matéria orgânica, o estabelecimento balanceado e concomitante de ambos os processos (metanogênese e sulfetogênese) passa a ser desejável (LENS et al., 1998). De fato, a viabilidade de reatores tratando águas residuárias ricas em matéria orgânica e sulfato pelas vias combinadas de redução de sulfato e produção de metano já foi demonstrada (GODOI et al., 2015; GIMÉNEZ et al., 2012; CADAVID et al., 1999). Assim, o presente estudo visou também proporcionar o estabelecimento dessas duas vias complementares de remoção de matéria orgânica pela vantagem advinda da produção de biogás rico em metano, o qual pode ser aproveitado para a geração de energia.

O gráfico da Figura 5.12 apresenta os resultados relativos à produção volumétrica de metano obtida ao longo das fases operacionais da ETAPA 1. Os valores estão corrigidos para as condições normais de temperatura e pressão (CNTP -1 atm e $\left.0^{\circ} \mathrm{C}\right)$ e levam em conta a fração de metano teoricamente dissolvida no meio líquido, calculada de acordo com a Lei de Henry (subseção 4.13.2, p. 98). 


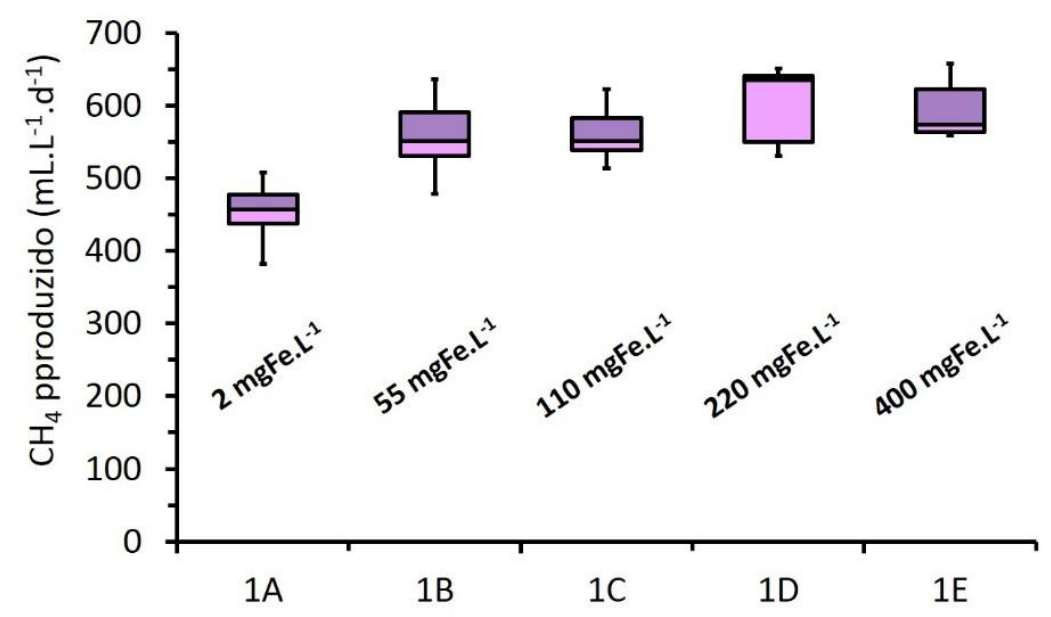

Figura 5.12: Análise estatística de Boxplot da produção volumétrica de metano da ETAPA 1. Dados corrigidos para as CNTP $\left(0^{\circ} \mathrm{C}\right.$ e $\left.1 \mathrm{~atm}\right)$.

Fonte: GODOI et al., 2017a.

A vazão volumétrica de metano (nas CNTP) apresentou tendência crescente da FASE 1A para a FASE 1B (de 450 para cerca de $580 \mathrm{~mL} \cdot \mathrm{L}^{-1}$ reator. $\mathrm{d}^{-1}$ ), permanecendo em seguida constante ao longo das fases operacionais subsequentes. É interessante notar que a adição de cloreto ferroso proporcionou esse aumento na produção de metano, o que também foi atribuído à precipitação do sulfeto, com diminuição dos seus efeitos inibitórios sobre as AM, como discutido anteriormente.

As análises de composição do biogás produzido no DFSBR durante a ETAPA 1 mostraram composição semelhante em todas as fases dessa ETAPA, sendo o biogás constituído por $71 \pm 4 \%$ de metano, $25 \pm 2 \%$ de gás carbônico e $4 \pm 0,5 \%$ de sulfeto de hidrogênio.

\subsubsection{Caracterização da diversidade microbiana-ETAPA 1}

As análises preliminares de microscopia de contraste de fase, realizadas em amostra da biomassa retirada do material suporte ao final da FASE 1A, indicaram morfologias 
semelhantes ao gênero Methanosaeta (hastes longas e filamentos) (Figura 5.13), cujos indivíduos utilizam exclusivamente o acetato em seu metabolismo (MADIGAN et al., 2000). Morfologias representativas do gênero Methanosarcina (cocos irregulares e cocos em agregados) (MADIGAN et al., 2000) não foram identificadas. Esse resultado sustenta a hipótese de que, em condições concomitantemente sulfetogênicas e metanogênicas, a remoção de ácido acético se dá predominantemente pela via metanogênica (com o enriquecimento da população de arqueias acetoclásticas).

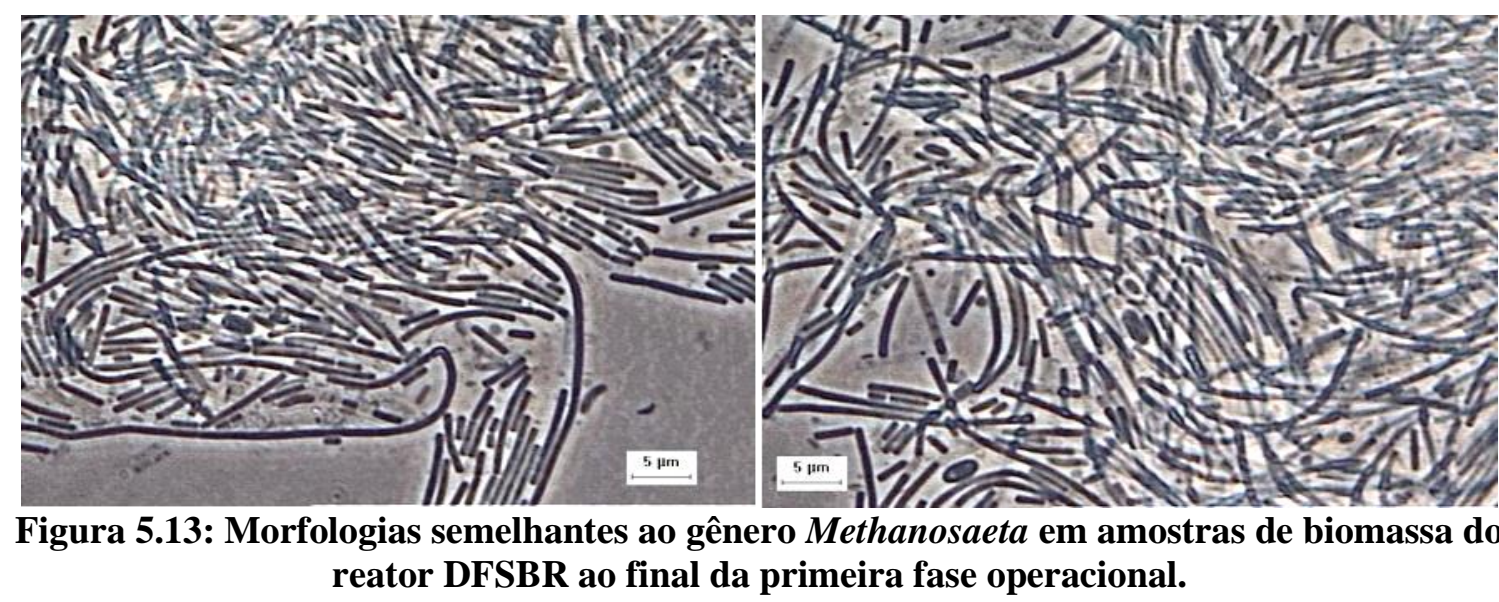

Fonte: $\mathrm{O}$ autor.

Bacilos arredondados, ovais e curvos também foram identificados (Figura 6.14) sendo essas morfologias usualmente associadas às bactérias redutoras de sulfato (HOLT et al., 1994). 

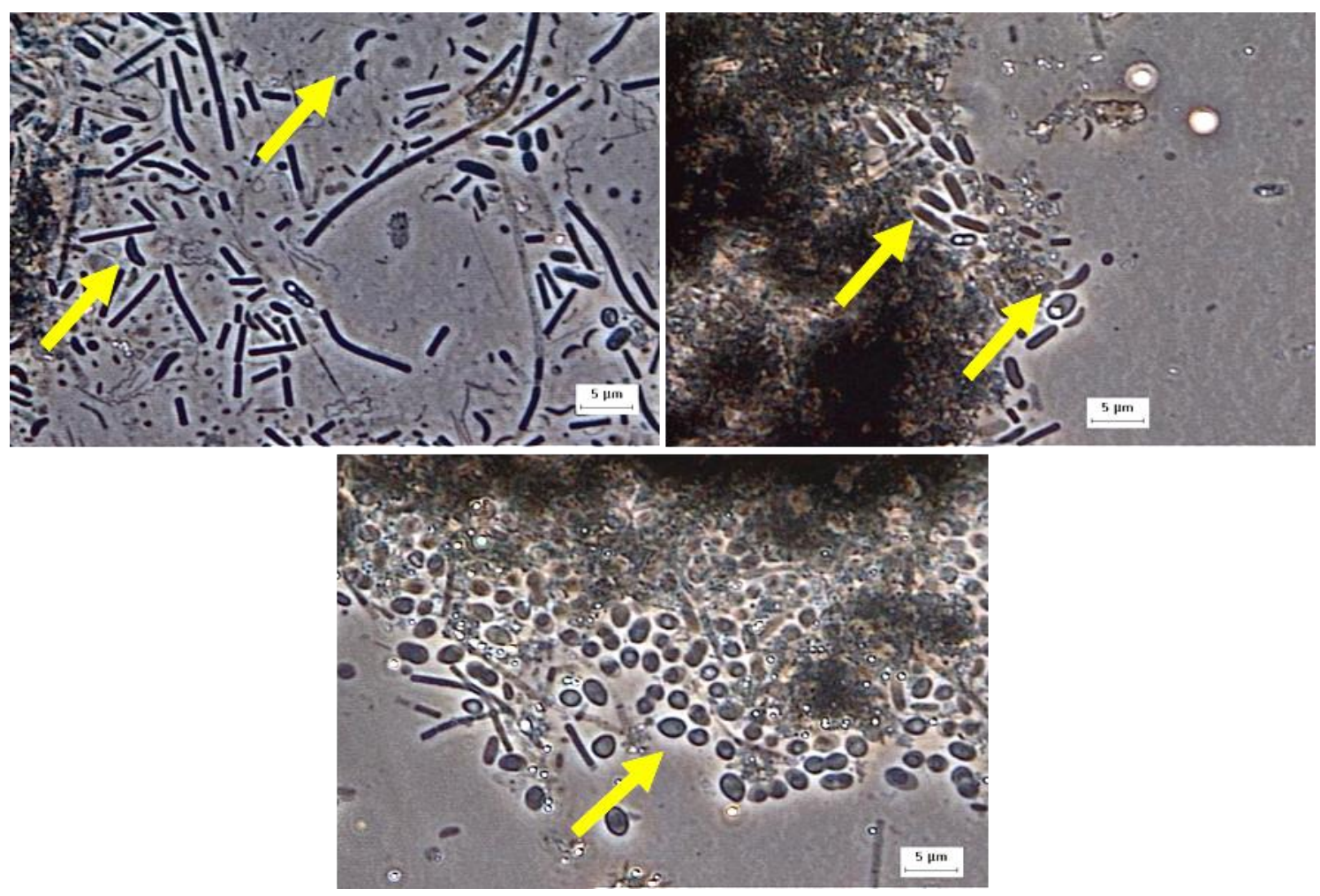

Figura 5.14: Morfologias semelhantes às de bactérias redutoras de sulfato.

Fonte: $\mathrm{O}$ autor.

Análises de DGGE em amostras do inóculo (IN-1) e de biomassa colhida no material suporte do DFSBR ao final das FASES 1A e 1E foram efetuadas para verificar a mudança na diversidade da biomassa quando submetida ao processo de tratamento de DAM sintética em co-digestão com vinhaça sintética.

Os dendrogramas mostrados na Figura 5.15 foram confeccionados conforme o método de agrupamento UPGMA com coeficientes de similaridade de Pearson, a partir dos padrões de bandas do DGGE efetuado com set primers para os Domínios Archaea (Figura 5.15.a) e Bacteria (Figura 5.15.b). 
(a) Domínio Archaea

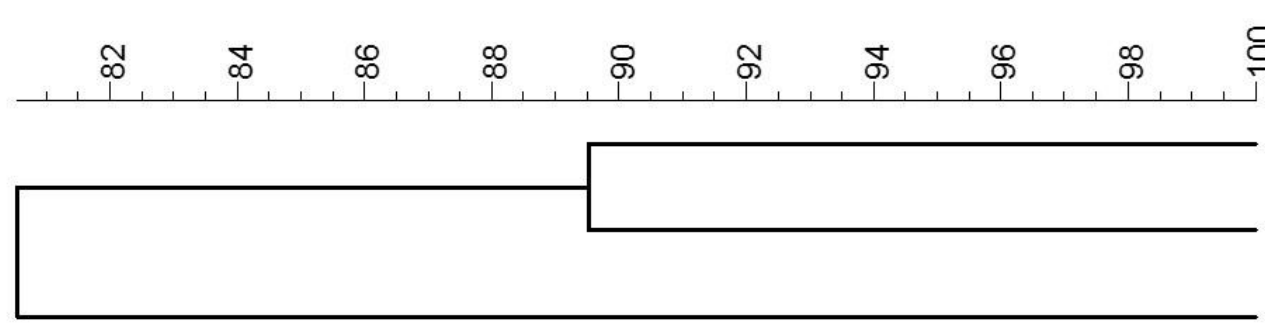
$\stackrel{8}{5}$

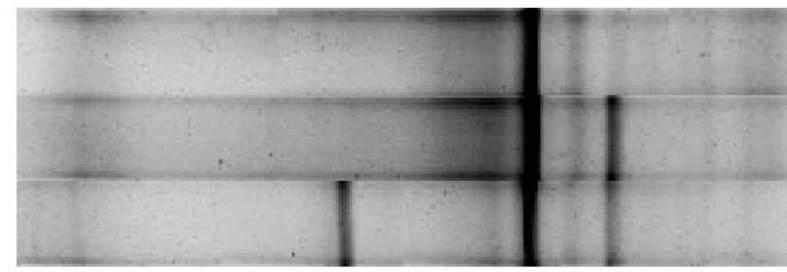

FASE 1A

FASE 1E

IN-1

(b) Domínio Bacteria
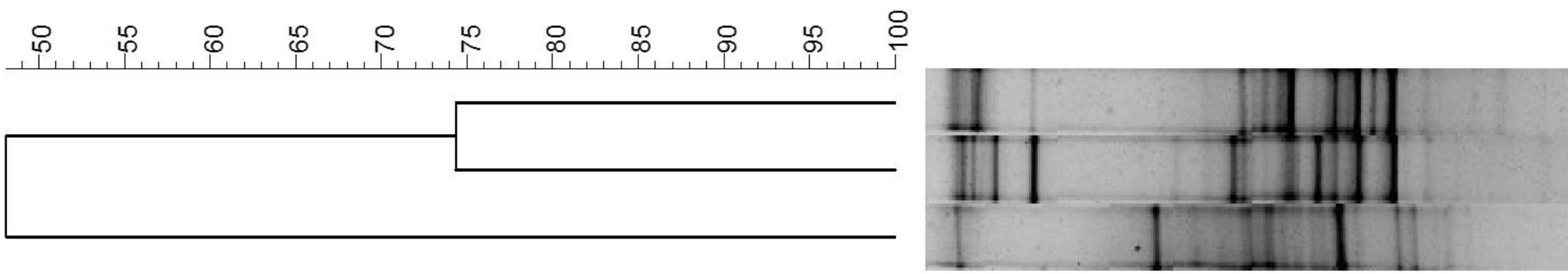

FASE 1A

FASE 1E

IN-1

Figura 5.15: Dendrogramas baseados no coeficiente de similaridade de Pearson a partir do padrão de bandas do DGGE encontrado no inóculo (IN-1) e em amostras de biomassa coletadas ao final das FASES 1A e 1E para os Domínios Archaea (a) e Bacteria (b).

Fonte: $\mathrm{O}$ autor. 
Com relação ao padrão de bandas obtidas para o DGGE do Domínio Archaea, observou-se coeficiente de similaridade de $80 \%$ entre o inóculo e as amostras do reator, sendo que a similaridade entre as amostras retiradas ao final da FASE 1A e ao final da FASE 1E apresentaram $89 \%$ de similaridade.

Uma vez que a diferença entre as FASES 1A e 1E se deve apenas à introdução de DAM sintética rica em ferro no DFSBR, pode-se inferir que as concentrações de ferro às quais a biomassa foi exposta ao longo da ETAPA 1 (gradativamente aumentada de 2 a 400 mg. $\mathrm{L}^{-1}$ ) não resultaram em modificações relevantes na população de Archaea do reator. O cruzamento desse resultado com as observações efetuadas por microscopia, anteriormente apresentadas, assim como o notável predomínio de uma banda específica no DGGE das três amostras (Figura 5.15.a) permite supor que o grupo de AM acetoclásticas predominantes no inóculo mantiveram o seu predomínio sobre a metanogênese no DFSBR.

Já com relação ao DGGE do Domínio Bacteria, o coeficiente de similaridade entre o inóculo utilizado (IN-1) e as amostras provenientes do DFSBR tratando DAM e vinhaça sintéticas foi da ordem de $49 \%$, marcadamente menor que a similaridade notada para o Domínio Archaea. A modificação da comunidade bacteriana na biomassa após a sua introdução no DFSBR pode ser atribuída às condições sulfato-redutoras às quais os microrganismos foram submetidos. De fato, o inóculo utilizado (IN-1) foi cultivado em um reator UASB dedicado ao tratamento de água residuária de abatedouro de aves, efluente caracterizado por altas concentrações de sólidos suspensos, óleos e graxas, e cuja natureza marcadamente proteica implica em altos teores de nitrogênio e fósforo (DEL NERY et al., 2007). A alimentação da biomassa com água residuária sintética baseada em carboidratos e ácidos orgânicos voláteis, além da alta concentração de sulfato aplicada (carga aplicada da ordem de $2,4 \mathrm{gSO}_{4}{ }^{2-} \cdot \mathrm{L}^{-1} \cdot \mathrm{d}^{-1}$ ) resultou em significativas mudanças estruturais da população de 
bactérias, com possível favorecimento dos grupos de BRS, além das bactérias fermentativas, favorecidas pela presença de sacarose no meio sintético.

A comparação entre os padrões de banda do DGGE entre as amostras obtidas ao final das FASES 1A e 1E para o Domínio Bacteria, por sua vez, apresentaram coeficiente de similaridade igual a $75 \%$. Assim como no caso da estrutura populacional do Domínio Archaea, a estrutura populacional pertencente ao Domínio Bacteria não foi expressivamente afetada pela introdução de metal no sistema. Dessa forma, houve manutenção de alta similaridade entre a biomassa analisada antes da introdução da DAM sintética no DFSBR e ao final da operação, após o reator ter sido submetido ao aumento gradual na dosagem de ferro. No entanto, ainda assim é possível supor o estabelecimento de alguns grupos de bactérias favorecidos pela presença das altas concentrações de $\mathrm{SO}_{4}{ }^{2-}$ e $\mathrm{Fe}^{2+}$ no sistema, dado o aparecimento de algumas bandas no DGGE da amostra oriunda da FASE 1E, as quais não se mostraram presentes nas amostras IN-1 e da FASE 1A (Figura 5.15.b).

\subsubsection{Considerações finais relativas à ETAPA 1}

O reator anaeróbio de leito fixo-estruturado e fluxo descendente (DFSBR) operando com relação $\mathrm{DQO} / \mathrm{SO}_{4}{ }^{2-}$ próxima de 2,0 possibilitou o estabelecimento equilibrado dos processos metanogênicos e sulfetogênicos simultâneos, com altas eficiências de remoção de matéria orgânica e sulfato. As concentrações de ácido acético foram mantidas sob controle, graças à manutenção de uma população metanogênica acetoclástica ativa no reator, o que também sugeriu o potencial do sistema para a recuperação de energia pela utilização do biogás. Essas observações indicaram a viabilidade da aplicação da relação DQO/sulfato proposta, validando a Sub-hipótese 1A: A relação DQO/sulfato maior que a estequiométrica (> 0,67) permitirá o estabelecimento dos processos metanogênico e sulfetogênico associados, 
levando à estabilidade do processo anaeróbio com eficiente remoção de matéria orgânica e sulfato.

Com relação à remoção de metais, o reator respondeu positivamente ao aumento nas cargas aplicadas de ferro, com cargas removidas de ferro crescentes, acompanhadas de diminuição nas concentrações de sulfeto dissolvido na fase líquida, o qual foi removido em conjunto com o ferro precipitado. A frequência na realização dos descartes de fundo do DFSBR se mostrou um fator chave para a manutenção de adequadas eficiências de remoção de ferro, viabilizando a recuperação de metais a partir do material precipitado coletado. Esses resultados ressaltaram o potencial da configuração de reator testada (DFSBR) para a precipitação e separação de metais provenientes de DAM, validando a Sub-hipótese 1B: $A$ configuração do leito fixo-estruturado e o fluxo descendente proporcionarão a formação e a precipitação de sulfetos metálicos no DFSBR, bem como sua separação na câmara inferior do reator.

Por fim, a água residuária sintética simulando a fração solúvel da vinhaça também se mostrou um doador de elétrons adequado para o processo, incentivando estudos posteriores com aplicação de vinhaça real, o que foi efetuado durante as etapas subsequentes do presente trabalho. 


\subsection{ETAPA 1: Avaliação da alcalinidade devida a sulfeto}

Partindo dos fundamentos teóricos já apresentados (seção 3.7, p. 52), a validade dos cálculos propostos para distinguir as diferentes parcelas de alcalinidade em reatores biológicos tratando águas residuárias ricas em sulfato foi avaliada. Os dados relativos à alcalinidade do reator DFSBR ao longo da ETAPA 1, operada sob cargas crescentes de metais, por sua vez, permitiram investigar a contribuição real do sulfeto dissolvido para a alcalinidade do meio líquido no sistema em questão (Objetivo específico 1: Sub-hipótese 1C).

\subsubsection{Avaliação da contribuição do íon bissulfeto $\left(H^{-}\right)$para a alcalinidade total do meio líquido}

Os resultados obtidos com a titulação das soluções padrões, preparadas conforme detalhado na seção 4.7, p. 83, e os respectivos cálculos efetuados para determinação das alcalinidades total $\left(\mathrm{A}_{\mathrm{T}}\right)$, parcial $\left(\mathrm{A}_{\mathrm{P}}\right)$, intermediária $\left(\mathrm{A}_{\mathrm{I}}\right)$, a bicarbonato $\left(\mathrm{A}_{\mathrm{BIC}}\right)$ e devida ao sulfeto ( $\mathrm{A}_{\mathrm{HS}-}$ ) estão resumido na Tabela 5.3. 
Tabela 5.3. Alcalinidades total $\left(A_{T}\right)$, parcial $\left(A_{P}\right)$, intermediária $\left(A_{I}\right)$, a bicarbonato $\left(A_{B I C}\right)$ e devida a sulfeto $\left(A_{H S}\right)$ nas soluções padrões.

\begin{tabular}{|c|c|c|c|c|c|c|c|c|c|c|c|}
\hline \multirow{3}{*}{ Parâmetro } & \multicolumn{11}{|c|}{ Soluções padrões } \\
\hline & 1 & 2 & 3 & 4 & 5 & 6 & 7 & 8 & 9 & 10 & 11 \\
\hline & \multicolumn{3}{|c|}{ Apenas $\mathrm{HCO}_{3}^{-}$} & \multicolumn{4}{|c|}{ Apenas $\mathbf{H S}^{-}$} & \multicolumn{4}{|c|}{$\mathrm{HCO}_{3}^{-}+\mathrm{HS}^{-}$} \\
\hline $\mathrm{HCO}_{3}^{-}\left(\mathrm{mg} \cdot \mathrm{L}^{-1}\right)$ & 1000 & 500 & 300 & - & - & - & - & 1000 & 1000 & 500 & 300 \\
\hline STD (mg.L $\left.L^{-1}\right)$ & - & - & - & 840 & 340 & 170 & 150 & 840 & 340 & 170 & 150 \\
\hline Titulante $-\mathrm{H}_{2} \mathrm{SO}_{4}(\mathrm{~N})$ & 0,8 & 0,8 & 0,12 & 0,8 & 0,8 & 0,8 & 0,12 & 0,8 & 0,8 & 0,8 & 0,12 \\
\hline $\mathrm{pH}$ inicial & $\begin{array}{l}8,35 \\
\pm 0,03\end{array}$ & $\begin{array}{l}8,26 \\
\pm 0,02\end{array}$ & $\begin{array}{l}8,58 \\
\pm 0,04\end{array}$ & $\begin{array}{l}8,31 \\
\pm 0,04\end{array}$ & $\begin{array}{l}8,28 \\
\pm 0,09\end{array}$ & $\begin{array}{l}8,32 \\
\pm 0,05\end{array}$ & $\begin{array}{l}8,37 \\
\pm 0,04\end{array}$ & $\begin{array}{l}8,30 \\
\pm 0,07\end{array}$ & $\begin{array}{l}8,33 \\
\pm 0,05\end{array}$ & $\begin{array}{l}8,31 \\
\pm 0,01\end{array}$ & $\begin{array}{l}8,33 \\
\pm 0,05\end{array}$ \\
\hline $\mathrm{A}_{\mathrm{P}}\left(\mathrm{mgCaCO}_{3} \cdot \mathrm{L}^{-1}\right)$ & $\begin{array}{l}616 \\
\pm 29\end{array}$ & $\begin{array}{l}315 \\
\pm 9\end{array}$ & $\begin{array}{l}226 \\
\pm 5\end{array}$ & $\begin{array}{l}1272 \\
\pm 8\end{array}$ & $\begin{array}{l}480 \\
\pm 16\end{array}$ & $\begin{array}{l}280 \\
\pm 12\end{array}$ & $\begin{array}{l}216 \\
\pm 14\end{array}$ & $\begin{array}{l}1808 \\
\pm 11\end{array}$ & $\begin{array}{l}1003 \\
\pm 32\end{array}$ & $\begin{array}{l}517 \\
\pm 17\end{array}$ & $\begin{array}{l}440 \\
\pm 18\end{array}$ \\
\hline $\mathrm{A}_{\mathrm{I}}\left(\mathrm{mgCaCO} \mathrm{Ca}_{3} \cdot \mathrm{L}^{-1}\right)$ & $\begin{array}{l}128 \\
\pm 12\end{array}$ & $\begin{array}{l}101 \\
\pm 5\end{array}$ & $\begin{array}{l}32 \\
\pm 6\end{array}$ & $\begin{array}{l}141 \\
\pm 9\end{array}$ & $\begin{array}{l}101 \\
\pm 12\end{array}$ & $\begin{array}{l}56 \\
\pm 8\end{array}$ & $\begin{array}{l}23 \\
\pm 3\end{array}$ & $\begin{array}{l}256 \\
\pm 10\end{array}$ & $\begin{array}{l}267 \\
\pm 28\end{array}$ & $\begin{array}{l}120 \\
\pm 14\end{array}$ & $\begin{array}{l}52 \\
\pm 20\end{array}$ \\
\hline $\mathrm{A}_{\mathrm{T}}\left(\mathrm{mgCaCO}_{3} \cdot \mathrm{L}^{-1}\right)$ & $\begin{array}{l}744 \\
\pm 18\end{array}$ & $\begin{array}{l}416 \\
\pm 14\end{array}$ & $\begin{array}{l}257 \\
\pm 5\end{array}$ & $\begin{array}{l}1413 \\
\pm 112\end{array}$ & $\begin{array}{l}581 \\
\pm 28\end{array}$ & $\begin{array}{l}336 \\
\pm 5\end{array}$ & $\begin{array}{l}238 \\
\pm 13\end{array}$ & $\begin{array}{l}2064 \\
\pm 9\end{array}$ & $\begin{array}{l}1269 \\
\pm 41\end{array}$ & $\begin{array}{l}637 \\
\pm 5\end{array}$ & $\begin{array}{l}492 \\
\pm 36\end{array}$ \\
\hline $\mathrm{f}_{\mathrm{Ai} / \mathrm{At}}(\%)$ & 17 & 24 & 13 & 10 & 17 & 17 & 10 & 12 & 21 & 19 & 11 \\
\hline $\mathrm{A}_{\mathrm{BIC}}\left(\mathrm{mgCaCO}_{3} \cdot \mathrm{L}^{-1}\right)^{*}$ & 820 & 410 & 246 & - & - & - & - & 820 & 820 & 410 & 246 \\
\hline $\mathrm{A}_{\mathrm{HS}-}\left(\mathrm{mgCaCO}_{3} \cdot \mathrm{L}^{-1}\right)$ & - & - & - & 1252 & 505 & 252 & 225 & 1252 & 508 & 254 & 224 \\
\hline $\mathrm{A}_{\mathrm{T}}^{\mathrm{EXP}}\left(\mathrm{mgCaCO}_{3} \cdot \mathrm{L}^{-1}\right)^{* *}$ & - & - & - & - & - & - & - & 2072 & 1328 & 664 & 471 \\
\hline $\mathrm{A}_{\mathrm{BIC}}{ }^{\mathrm{OBS}}\left(\mathrm{mgCaCO}_{3} \cdot \mathrm{L}^{-1}\right)$ & 744 & 416 & 257 & - & - & - & - & $744 * * *$ & $744 * * *$ & $416 * * *$ & $257 * * *$ \\
\hline $\mathrm{A}_{\mathrm{HS}-}{ }^{\mathrm{OBS}}\left(\mathrm{mgCaCO}_{3} \cdot \mathrm{L}^{-1}\right)$ & - & - & - & 1413 & 581 & 336 & 238 & 1320 & 525 & 221 & 235 \\
\hline $\mathrm{AT}_{\mathrm{REC}}(\%)$ & - & - & - & - & - & - & - & 100 & 96 & 96 & 105 \\
\hline $\mathrm{ABIC}_{\mathrm{REC}}(\%)$ & 91 & 101 & 104 & - & - & - & - & - & - & - & - \\
\hline $\mathrm{AHS}_{\mathrm{REC}}^{-}(\%)$ & - & - & - & 113 & 115 & 133 & 106 & 105 & 103 & 87 & 105 \\
\hline
\end{tabular}

*Valor teórico considerando que $1 \mathrm{mg}$ de $\mathrm{HCO}_{3}{ }^{-}$fornece uma alcalinidade equivalente a $0.82 \mathrm{mg} \mathrm{de} \mathrm{CaCO}_{3}$.

$* * \mathrm{~A}_{\mathrm{T}}^{\text {EXP. }}$ : Alcalinidade total esperada = Soma dos valores teóricos de $\mathrm{A}_{\mathrm{BIC}}$ e $\mathrm{A}_{\mathrm{HS}-\text {. }}$

***Os valores obtidos pelas titulações das soluções 1 a 3 foram escolhidos como valores de $\mathrm{A}_{\mathrm{BIC}}{ }^{\text {OBS }}$ de referência para as demais soluções.

Fonte: GODOI et al., 2017b. 
A alcalinidade devida a sulfetos observada $\left(\mathrm{A}_{\mathrm{HS}-}{ }^{*}\right)$ foi determinada descontando-se o valor da alcalinidade a bicarbonato observada $\left(\mathrm{A}_{\mathrm{BIC}}{ }^{\mathrm{OBS}}\right)$ encontrado nas soluções padrões 1 $\left(1000 \mathrm{mgHCO}_{3}{ }^{-} \cdot \mathrm{L}^{-1}\right), 2\left(500 \mathrm{mg} \mathrm{HCO}_{3}{ }^{-} \mathrm{L}^{-1}\right)$ ou $3\left(300 \mathrm{mg} \mathrm{HCO}_{3}{ }^{-} \mathrm{L}^{-1}\right)$ do valor de alcalinidade total (AT) medido por titulação nas amostras das soluções 8, 9, 10 e 11 (contendo a mistura de $\mathrm{HCO}_{3}{ }^{-}+\mathrm{HS}^{-}$). Estes valores foram comparados com os valores teóricos de alcalinidade a sulfeto estimados pela aplicação da Equação (4.6). Além disso, a fração relativa de alcalinidade total $\left(\mathrm{A}_{\mathrm{T}}\right)$ determinada abaixo de $\mathrm{pH}=5,75(\mathrm{AI})$ também foi determinada $\left(\mathrm{f}_{\mathrm{Ai} / \mathrm{At}}=\right.$ $100 \times \mathrm{A}_{\mathrm{I}}\left(\mathrm{A}_{\mathrm{T}}\right)$, assim como foram calculados os fatores de recuperação da alcalinidade devida a sulfeto $\left(\mathrm{AHS}_{\mathrm{REC}}^{-}=100 \quad \mathrm{x} \mathrm{A}_{\mathrm{HS}-}{ }^{\mathrm{OBS}} / \mathrm{A}_{\mathrm{HS}-}\right)$, alcalinidade devida a bicarbonato $\left(\mathrm{ABIC} \mathrm{REC}_{\mathrm{R}}=100 \times \mathrm{A}_{\mathrm{BIC}}{ }^{\mathrm{OBS}} / \mathrm{A}_{\mathrm{BIC}}\right)$ e alcalinidade total esperada $\left(\mathrm{AT}_{\mathrm{REC}}=100 \times \mathrm{A}_{\mathrm{T}} / \mathrm{A}_{\mathrm{T}}{ }^{\mathrm{EXP}}\right)$.

Os dados apresentados na Tabela 5.3 mostraram que a maior fração da alcalinidade devida ao sulfeto em solução $(83$ - 90\%) é medida em conjunto com o bicarbonato ao longo da titulação até $\mathrm{pH}=5,75$. A fração restante $\left(\mathrm{f}_{\mathrm{Ai} / \mathrm{At}}=10-17 \%\right)$ é titulada entre os valores de pH 5,75 e 4,30. Este comportamento é similar ao da alcalinidade a bicarbonato, a qual usualmente apresenta cerca de $20 \%$ nesta mesma faixa de $\mathrm{pH}$, abaixo de 5,75. Esta semelhança entre ambos os sistemas $\left(\mathrm{HCO}_{3}{ }^{-} / \mathrm{CO}_{2}\right.$ e $\left.\mathrm{HS}^{-} / \mathrm{H}_{2} \mathrm{~S}\right)$ pode ser explicado pelas constantes de dissociação (pKa) próximas entre eles, sendo da ordem de 6,99 para o par sulfeto e de 6,30 para o par do bicarbonato. Portanto, é difícil separar a contribuição de cada ânion na medição titulométrica da alcalinidade.

Por outro lado, para as soluções contendo apenas o íon $\mathrm{HS}^{-}$(4 a 7) a alcalinidade a sulfeto observada ( $\mathrm{A}_{\mathrm{HS}-}{ }^{\mathrm{OBS}}$ ) se aproximou satisfatoriamente dos valores teóricos estimados para AHS- $\left(\mathrm{AHS}_{\mathrm{REC}}^{-}=117 \pm 12 \%\right)$. Tal resultado comprovou que os cálculos propostos são adequados para prever a porção de alcalinidade fornecida pelo sulfeto em solução. De fato, os

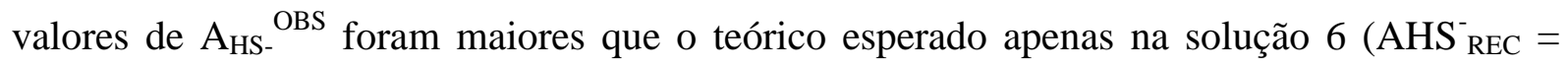
133\%). Uma vez que uma solução de ácido sulfúrico com alta normalidade $(0,8 \mathrm{~N})$ foi 
empregada na titulação dessa amostra, uma única gota leva a um decréscimo significativo de pH entre 5,75 e 4,30, acarretando na superestimação da alcalinidade devida ao sulfeto. Com o objetivo de se obterem resultados mais acurados, uma solução de $\mathrm{H}_{2} \mathrm{SO}_{4}$ de menor concentração $(0,12 \mathrm{~N})$ foi utilizada com sucesso durante a titulação da solução 7 , com melhores resultados $\left(\mathrm{AHS}_{\mathrm{REC}}^{-}=106 \%\right)$. No entanto, sempre que possível uma solução de ácido mais concentrada deve ser escolhida para evitar titulações excessivamente demoradas, o que pode implicar em perdas de sulfeto por volatilização.

Também é interessante notar que, para as soluções 8 a 11, simulando o efluente típico de reatores sulfetogênicos, os fatores de recuperação da alcalinidade total esperada $\left(\mathrm{AT}_{\mathrm{REC}}\right)$ foram sempre próximos de 100\% (Tabela 5.3). Essa observação indica claramente que a abordagem aqui empregada permite predizer adequadamente a real contribuição de ambos os ânions $\left(\mathrm{HCO}_{3}{ }^{-}\right.$e $\left.\mathrm{HS}^{-}\right)$para a alcalinidade total do sistema.

A Tabela 5.4 apresenta os resultados dos testes efetuados para verificar o comportamento da alcalinidade devida a sulfeto na presença de ácido acético $\left(\mathrm{CH}_{3} \mathrm{COOH}\right)$, dosado para simular uma sobrecarga de ácidos orgânicos em reatores anaeróbios. As soluções 3, 7 e 11 foram tituladas novamente após a dosagem de uma alíquota de solução concentrada de ácido acético com concentrações finais de ácido da ordem de 150 ou 300 mg.L $\mathrm{L}^{-1}$. O consumo esperado das alcalinidades a sulfeto $\left(\mathrm{AHS}^{-} \mathrm{CONS} \mathrm{ESP}^{-}\right)$, a bicarbonato (ABIC ${ }^{\text {CONS ESP }}$ ) e da alcalinidade total (AT ${ }^{\text {CONS ESP }}$ ) pela dosagem do ácido acético foram comparados com os consumos reais obtidos (AHS ${ }^{- \text {CONSUMIDA; }}$ ABIC ${ }^{\text {CONSUMIDA }}$ e AT ${ }^{\text {CONSUMIDA }}$ ). 
Tabela 5.4. Dinâmica das frações de alcalinidade devida a sulfeto e a bicarbonato após a adição de ácido acético (titulações realizadas com $\mathrm{H}_{2} \mathrm{SO}_{4} 0,12 \mathrm{~N}$ ).

\begin{tabular}{|c|c|c|c|c|c|}
\hline \multirow{2}{*}{ Parâmetros } & \multicolumn{5}{|c|}{ Antes da adição de ácido acético } \\
\hline & Controle I & Controle II & 3 , & 7 & 11 ' \\
\hline $\mathrm{HCO}_{3}^{-}\left(\mathrm{mg} \cdot \mathrm{L}^{-1}\right)$ & - & - & 300 & - & 300 \\
\hline $\operatorname{STD}\left(m g . L^{-1}\right)$ & - & - & - & 150 & 150 \\
\hline $\mathrm{A}_{\mathrm{HS}-}\left(\mathrm{mgCaCO}_{3} \cdot \mathrm{L}^{-1}\right)$ & - & - & - & 225 & 225 \\
\hline $\mathrm{A}_{\mathrm{BIC}}\left(\mathrm{mgCaCO}_{3} \cdot \mathrm{L}^{-1}\right)$ & - & - & 246 & - & 246 \\
\hline $\mathrm{A}_{\mathrm{T}}\left(\mathrm{mgCaCO}_{3} \cdot \mathrm{L}^{-1}\right)$ & - & - & 246 & 225 & 471 \\
\hline \multicolumn{6}{|c|}{ Após a adição de ácido acético } \\
\hline Ácido acético (mg.L $\left.{ }^{-1}\right)$ & 150 & 300 & 150 & 150 & 300 \\
\hline pH inicial & $\begin{array}{l}5,75^{*} \\
\pm 0,01\end{array}$ & $\begin{array}{l}5,75^{*} \\
\pm 0,02\end{array}$ & $\begin{array}{l}6,61 \\
\pm 0,01\end{array}$ & $\begin{array}{l}6,72 \\
\pm 0,04\end{array}$ & $\begin{array}{l}6,52 \\
\pm 0,02\end{array}$ \\
\hline $\mathrm{A}_{\mathrm{P}}\left(\mathrm{mgCaCO} 3 \cdot \mathrm{L}^{-1}\right)$ & - & - & $97 \pm 1$ & $76 \pm 7$ & $156 \pm 2$ \\
\hline $\mathrm{A}_{\mathrm{I}}\left(\mathrm{mgCaCO}_{3} \cdot \mathrm{L}^{-1}\right)$ & $96 \pm 3$ & $183 \pm 1$ & $110 \pm 8$ & $93 \pm 4$ & $202 \pm 6$ \\
\hline $\mathrm{A}_{\mathrm{T}}\left(\mathrm{mgCaCO}_{3} \cdot \mathrm{L}^{-1}\right)$ & - & - & $207 \pm 9$ & $169 \pm 5$ & $358 \pm 8$ \\
\hline $\mathrm{A}_{\mathrm{VFA}}\left(\mathrm{mgCaCO}_{3} \cdot \mathrm{L}^{-1}\right)^{* *}$ & $96 \pm 3$ & $183 \pm 1$ & $96 \pm 3$ & $96 \pm 3$ & $183 \pm 1$ \\
\hline $\mathrm{A}_{\mathrm{T}}-\mathrm{A}_{\mathrm{VFA}}\left(\mathrm{mgCaCO}_{3} \cdot \mathrm{L}^{-1}\right)$ & - & - & 111 & 73 & 175 \\
\hline $\mathrm{AHS}^{-\mathrm{CONS} \mathrm{ESP}}\left(\mathrm{mgCaCO}_{3} \cdot \mathrm{L}^{-1}\right)$ & - & - & - & $125 * * *$ & - \\
\hline $\mathrm{AHS}^{-\mathrm{CONSUMIDA}}\left(\mathrm{mgCaCO}_{3} \cdot \mathrm{L}^{-1}\right)$ & - & - & - & 152 & - \\
\hline $\mathrm{ABIC}{ }^{\mathrm{CONS} \mathrm{ESP}}\left(\mathrm{mgCaCO}_{3} \cdot \mathrm{L}^{-1}\right)$ & - & - & $125 * * *$ & - & - \\
\hline $\mathrm{ABIC}{ }^{\text {CONSUMIDA }}\left(\mathrm{mgCaCO}_{3} \cdot \mathrm{L}^{-1}\right)$ & - & - & 135 & - & - \\
\hline $\mathrm{AT}^{\mathrm{CONS} \mathrm{ESP}}\left(\mathrm{mgCaCO} \cdot \mathrm{L}^{-1}\right)$ & - & - & - & - & $249 * * *$ \\
\hline $\mathrm{AT}{ }^{\text {CONSUMIDA }}\left(\mathrm{mgCaCO}_{3} \cdot \mathrm{L}^{-1}\right)$ & - & - & - & - & 296 \\
\hline Erro $(\%) * * * *$ & - & - & 8 & 22 & 19 \\
\hline
\end{tabular}

*Ajustado com solução concentrada de $\mathrm{NaOH}(1 \mathrm{~N})$.

$* * \mathrm{~A}_{\mathrm{VFA}}=\mathrm{A}_{\mathrm{I}}$ das soluções padrões contendo apenas ácido acético. Estes valores foram assumidos como valores de referência para as demais soluções.

***Valores esperados considerando que $1.0 \mathrm{mg}$ de $\mathrm{CH}_{3} \mathrm{COOH}$ consome $0.83 \mathrm{mg}$ de $\mathrm{CaCO}_{3}$. $* * * *$ Erro $(\%)=100 \mathrm{x} \mid$ (Alcalinidade consumida - Consumo esperado $) \div$ Consumo esperado $\mid$.

Fonte: GODOI et al., 2017b.

A dosagem de ácido acético nas amostras revelou a habilidade do HS- em atuar como tampão do meio líquido pela neutralização do $\mathrm{CH}_{3} \mathrm{COOH}$ e evitar a queda brusca do $\mathrm{pH}$, de maneira similar ao íon bicarbonato (Tabela 5.4). $\mathrm{O}$ consumo mais pronunciado da alcalinidade devida ao sulfeto ( $22 \%$ maior que o valor esperado, ao contrário de $8 \%$ da amostra contendo bicarbonato) pode ser atribuído à alta volatilidade do sulfeto de hidrogênio produzido, intensificada pelo abaixamento instantâneo do pH ocasionado com a adição do 
ácido, bem como pelo tempo demandado para realizar a titulação. Neste caso, o escape do $\mathrm{H}_{2} \mathrm{~S}$ também contribui com a manutenção do $\mathrm{pH}$ do meio, uma vez que o deslocamento das espécies de sulfeto dissolvido na direção da formação de sulfeto molecular favorece a captura de prótons (Equação (3.14)). Este fato pode ser observado no efluente de reatores sulfetogênicos, os quais usualmente apresentam maiores valores de $\mathrm{pH}$ em comparação com o $\mathrm{pH}$ interno do meio líquido do reator. $\mathrm{O}$ mesmo ocorre devido ao desprendimento do $\mathrm{CO}_{2}$ (SPEECE, 1996). Quando em solução, ambos os ânions atuam concomitantemente no tamponamento da solução. Além do mais, a soma das alcalinidades consumidas observadas na soluções 3' e 7' ( $\approx 290 \mathrm{mgCaCO}_{3}$.L-1) foram próximas do consumo observado nas soluções contendo a mistura de ambos os ânions $\left(296 \mathrm{mgCaCO}_{3} \cdot \mathrm{L}^{-1}\right)$. Este resultado reforça a confiabilidade dos cálculos propostos em predizer a real contribuição (e o consumo) de cada ânion na alcalinidade global da amostra.

Para visualizar o comportamento da alcalinidade a sulfeto em reatores sulfetogênicos, a qual é diretamente relacionada com o pH do meio líquido e à concentração de sulfeto total dissolvido (STD), traçou-se o gráfico apresentado pela Figura 5.16, partindo-se das Equações (4.31) e (4.6), anteriormente propostas. Nesta simulação, os valores de $\mathrm{pH}$ de 5,0, 6,0, 7,0, 8,0 e 9,0 foram escolhidos para representar a faixa de $\mathrm{pH}$ na qual são operados os reatores anaeróbios. 


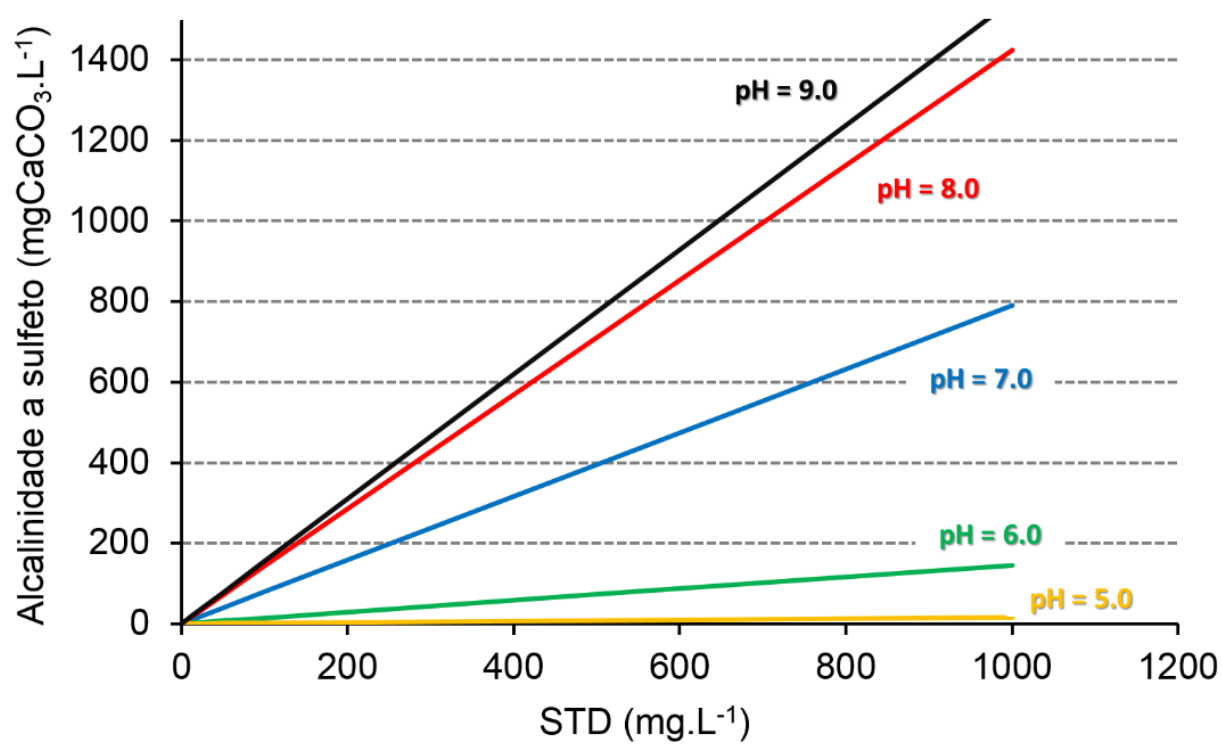

Figura 5.16. Alcalinidade a sulfeto em diversos níveis de concentração de sulfeto total dissolvido (STD) e valores de pH dentro da faixa usual para a digestão anaeróbia $(5,0<\mathrm{pH}<9,0)$.

Fonte: GODOI et al., 2017b.

Pode-se inferir que para valores de $\mathrm{pH}$ abaixo de 6,0, mesmo altas concentrações de STD fornecem quantias desprezíveis de alcalinidade a sulfeto, uma vez que apenas uma fração marginal de sulfeto estará presente na forma dissociada (HS') (Figura 3.3). Nestas condições, o sulfeto molecular predomina, o qual não apresenta capacidade de tamponamento por não se tratar de uma fórmula química aceptora de prótons. De fato, em valores de $\mathrm{pH}$ abaixo de 5,75 nem mesmo o bicarbonato se apresenta em concentrações consideráveis, já que o equilíbrio do par $\mathrm{HCO}_{3}{ }^{-} / \mathrm{CO}_{2}$ também é deslocado para a formação de gás carbônico (WOLF-GLADROW et al., 2007).

Por outro lado, para valores de $\mathrm{pH}$ na faixa neutra à alcalina $(6,0<\mathrm{pH}<8,0)$, nas quais a maior parte do STD se apresenta na forma dissociada, participação relevante do íon $\mathrm{HS}^{-}$para a alcalinidade total do sistema é esperada. Para valores de $\mathrm{pH}$ acima de 9,0, por outro lado, o íon dissulfeto $\left(S^{2-}\right)$ passa a contribuir de forma mais expressiva para a alcalinidade da solução, uma vez que essa espécie é capaz de neutralizar o dobro de prótons em relação ao HS'. Todavia, esta condição não foi contemplada no presente estudo, por esta 
faixa de pH não ser desejável para a operação de reatores anaeróbios. Com relação ao sistema bicarbonato/carbonato, em condições de extrema basicidade, a alcalinidade a carbonato (a partir de $\mathrm{pH}=8,30$ ) e a hidróxido (a partir de $\mathrm{pH}=10,0$ ) se tornam predominantes (JENKINS; MOORE, 1977).

Um exemplo prático pode ser encontrado no estudo conduzido por SARTI e ZAIAT (2011), os quais operaram um reator anaeróbio em bateladas sequenciais (AnSBR) aplicado à redução de sulfato em água residuária proveniente da sulfonação de óleos vegetais. Durante o processo, a carga de sulfato aplicada foi elevada gradualmente. Ao longo da primeira fase operacional $\left(0,25 \mathrm{gSO}_{4}{ }^{2-} \cdot \mathrm{L}^{-1}\right)$, o efluente do reator apresentou $\mathrm{pH}$ médio de 7,3 e mínima concentração de sulfeto total dissolvido ( $\left.\mathrm{STD}=1,26 \mathrm{mg} \cdot \mathrm{L}^{-1}\right)$. Dessa forma, a alcalinidade medida no efluente $\left(188 \mathrm{mg} \mathrm{CaCO}_{3} \cdot \mathrm{L}^{-1}\right)$ pode ser atribuída exclusivamente à produção de bicarbonato pelo metabolismo dos organismos envolvidos. Quando o reator passou a operar com concentrações afluentes de sulfato da ordem de $1 \mathrm{gSO}_{4}{ }^{2-} \cdot \mathrm{L}^{-1}$, observou-se uma queda no pH efluente para próximo de 7,1, o que foi acompanhado, por outro lado, de um aumento no STD acumulado na fase líquida para 173,5 mg.L ${ }^{-1}$ (SARTI; ZAIAT, 2011). A alcalinidade total $\left(\mathrm{A}_{\mathrm{T}}\right)$ produzida nessa fase $\left(432 \mathrm{mgCaCO}_{3} \cdot \mathrm{L}^{-1}\right)$ pode então ser caracterizada por uma expressiva contribuição do íon bissulfeto, responsável por $35 \%$ da $\mathrm{A}_{\mathrm{T}}$, o que foi determinado conforme o procedimento de cálculo aqui apresentado (Equações (4.31) e (4.6)). Na última fase, operada com sulfato afluente de $3 \mathrm{gSO}_{4}{ }^{2-} \cdot \mathrm{L}^{-1}$, apesar do aumento no STD $\left(197,7 \mathrm{mg} . \mathrm{L}^{-1}\right)$, a contribuição do sulfeto para a alcalinidade do sistema $\left(\mathrm{A}_{\mathrm{T}}=517 \mathrm{mgCaCO} \cdot \mathrm{L}^{-1}\right)$ foi de apenas $6 \%$. Uma explicação para esse resultado se deve ao baixo pH do efluente $(6,05)$ observado nessa fase (SARTI; ZAIAT, 2011), implicando no predomínio do sulfeto molecular $\left(\mathrm{H}_{2} \mathrm{~S}\right)$ no lugar do íon $\mathrm{HS}^{-}$. Essa constatação corrobora o comportamento da alcalinidade devida ao bissulfeto conforme previsto pela Figura 5.16. 
Uma vez que os cálculos teóricos propostos se mostraram adequados para prever a alcalinidade devida ao sulfeto em solução, a presente abordagem foi aplicada ao reator DFSBR operando durante a ETAPA 1, conforme será mostrado na subseção a seguir.

\subsubsection{Alcalinidade devida a sulfeto no DFSBR}

O reator DFSBR tratando DAM sintética suplementada com vinhaça sintética foi submetido às concentrações crescentes de ferro (2 a $\left.400 \mathrm{mg} . \mathrm{L}^{-1}\right)$, as quais implicaram no decréscimo das concentrações de STD. Ao mesmo tempo, as determinações de alcalinidade total e a bicarbonato mostraram um comportamento decrescente, acompanhando o aumento da precipitação do sulfeto em solução, conforme está apresentado na Tabela 5.5.

Tabela 5.5. Valores médios e desvios-padrões das concentrações de ferro afluente, HS; alcalinidade total e pH no efluente do reator DFSBR.

\begin{tabular}{|c|c|c|c|c|c|}
\hline \multirow[t]{2}{*}{ Parâmetros } & \multicolumn{5}{|c|}{ Condições experimentais* } \\
\hline & $\mathbf{1 A}$ & $1 B$ & $\mathbf{1 C}$ & $1 \mathrm{D}$ & $1 E$ \\
\hline Ferro (mg. $\left.\mathrm{L}^{-1}\right)$ & $2 \pm 1$ & $55 \pm 5$ & $110 \pm 10$ & $220 \pm 15$ & $400 \pm 70$ \\
\hline$\left[\mathrm{HS}^{-}\right]\left(\mathrm{mg} \cdot \mathrm{L}^{-1}\right)$ & $424 \pm 16$ & $124 \pm 64$ & $94 \pm 22$ & $33 \pm 42$ & $8 \pm 7$ \\
\hline $\mathrm{A}_{\mathrm{T}}\left(\mathrm{mgCaCO} \mathrm{CaC}_{3} \cdot \mathrm{L}^{-1}\right)$ & $2524 \pm 60$ & $2025 \pm 166$ & $1786 \pm 94$ & $1617 \pm 184$ & $1461 \pm 223$ \\
\hline $\mathrm{pH}$ efluente & $8,48 \pm 0,08$ & $8,46 \pm 0,09$ & $8,48 \pm 0,09$ & $8,27 \pm 0,48$ & $8,28 \pm 0,12$ \\
\hline
\end{tabular}

Fonte: GODOI et al., 2017b.

Assim, o aumento na dosagem de ferro causou uma redução gradual na alcalinidade medida no efluente do DFSBR. Uma vez que a precipitação de sulfetos metálicos resulta no consumo do íon $\mathrm{HS}^{-}$, bem como na liberação de prótons para o meio líquido, gerando acidez, a demanda por alcalinidade aumentou acompanhando o aumento na precipitação de ferro. Ao mesmo tempo, a concentração do íon HS-, por ser um componente do STD, diminuiu até valores desprezíveis. Assim, o sulfeto medido como alcalinidade durante a titulação ácida 
decaiu sensivelmente, enquanto que a alcalinidade a bicarbonato diminuiu menos notadamente, conforme ilustrado pela Figura 5.17.

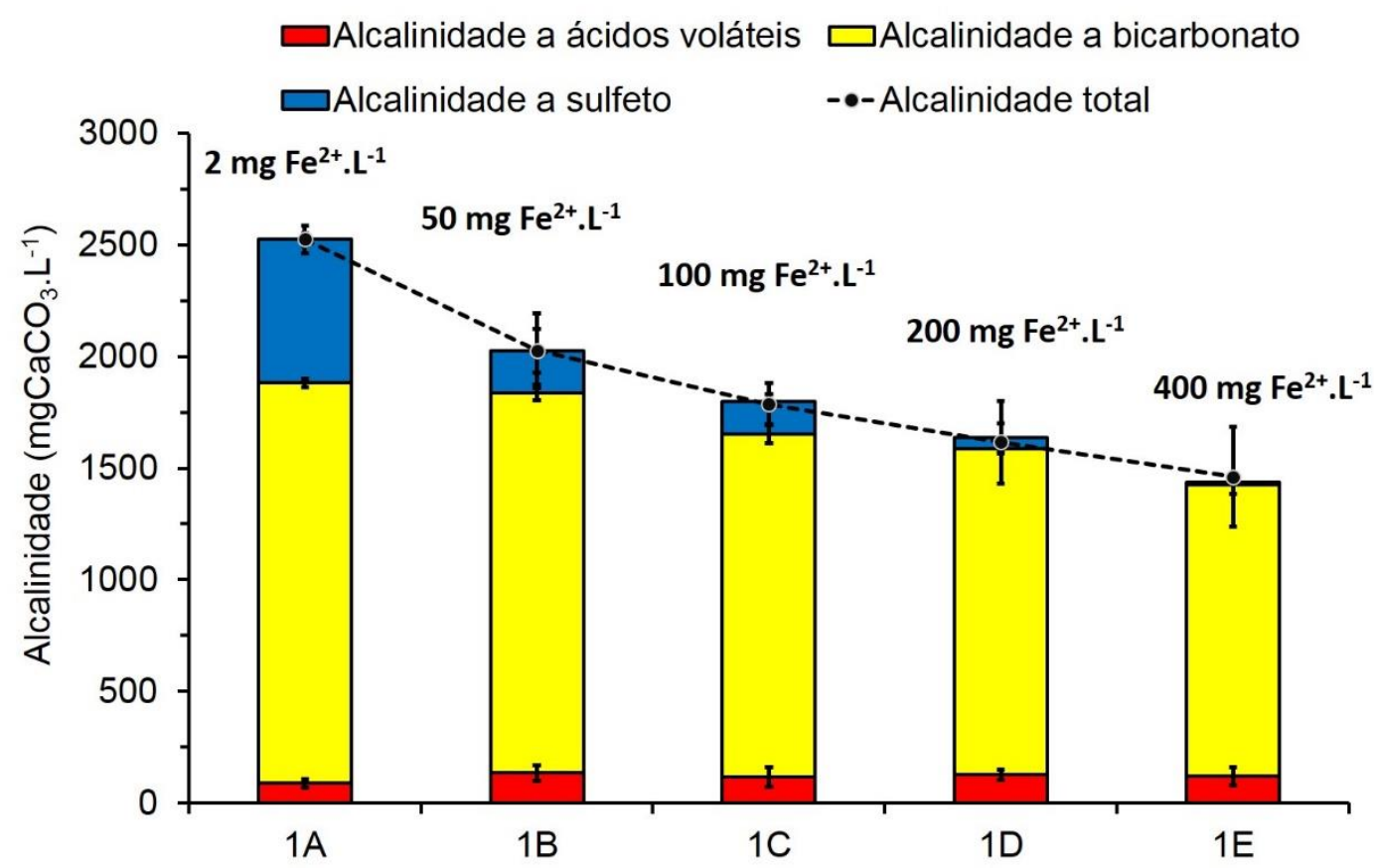

Figura 5.17. Características do efluente do DFSBR com relação às frações de alcalinidade total devidas a sulfeto, a bicarbonato e a ácidos voláteis durante a ETAPA 1. As barras de erros representam o desvio-padrão.

Fonte: GODOI et al., 2017b.

Os resultados demonstraram a contribuição do sulfeto dissolvido para com a alcalinidade total do reator ao longo da ETAPA 1. A alcalinidade devida ao sulfeto foi mais pronunciada durante a FASE 1A, operada com concentração mínima de ferro e, portanto, com maior disponibilidade de sulfeto dissolvido. Nessa condição operacional, $26 \%$ da alcalinidade total medida por titulação foi devida ao íon $\mathrm{HS}^{-}$em solução. Ainda que a alcalinidade total tenha decrescido ao longo de cada fase operacional, nenhuma instabilidade foi identificada no processo biológico. Durante as FASES 1B a 1E a porção de bicarbonato produzido pelo metabolismo das BRS (Equação (3.5)) foi capaz de manter o pH interno do reator próximo da neutralidade $(\mathrm{pH} \approx 7,20)$, enquanto que o efluente do DFSBR apresentou $\mathrm{pH}$ da ordem de 
8,30 ou mais. Devido às baixas concentrações de STD durante a FASE 1E, apenas a alcalinidade devida estritamente ao bicarbonato em solução foi responsável por garantir o adequado tamponamento do sistema.

Apesar da carência de alcalinidade em sistemas sulfetogênicos tratando DAM ricas em metais ser usualmente atribuída ao consumo do bicarbonato (SAHINKAYA et al., 2013; GONÇALVES et al., 2007), o presente estudo demonstrou que a queda na alcalinidade do sistema se deve, primeiramente, ao consumo do íon bissulfeto em solução, o qual é responsável por frações relevantes de alcalinidade.

SAHINKAYA et al. (2013) operaram um reator anaeróbio de leito fluidizado (RALF) tratando uma DAM sintética e utilizando etanol e lixiviado de aterro sanitário como doadores de elétrons. Imediatamente após a introdução do lixiviado (50\% da concentração de DQO), a concentração de STD e a alcalinidade total no reator alcançou cerca $440 \mathrm{mg} . \mathrm{L}^{-1}$ e 2482 $\operatorname{mgCaCO} 3 \cdot \mathrm{L}^{-1}$, respectivamente. Nessa condição, com $\mathrm{pH}$ de 8,0 , a contribuição do $\mathrm{HS}^{-}$para a alcalinidade do reator foi de $25 \%$. Já na fase posterior, caracterizada pela adição de vários metais, a alcalinidade total passou para $1070 \mathrm{mgCaCO}_{3} \cdot \mathrm{L}^{-1}$, o $\mathrm{pH}$ efluente caiu para $7,4 \mathrm{e} \mathrm{o}$ STD remanescente foi de $207 \mathrm{mg} . \mathrm{L}^{-1}$, resultando em uma participação do $\mathrm{HS}^{-}$da ordem de $22 \%$ da alcalinidade total. Já durante a última fase de operação, com lixiviado como única fonte de carbono e maiores concentrações de metais, uma queda acentuada da alcalinidade total (para $335 \mathrm{mgCaCO}_{3} \cdot \mathrm{L}^{-1}$ ) foi observada, seguida por valores menores de $\mathrm{pH}$ efluente $(6,6)$ e STD $\left(87 \mathrm{mg} \cdot \mathrm{L}^{-1}\right)$. Como consequência, verificou-se a diminuição da participação do íon $\mathrm{HS}^{-}$na alcalinidade do sistema (12\%). Assim, pode-se assumir que a redução na disponibilidade do $\mathrm{HS}^{-}$, provocada pelo aumento na carga aplicada de metais, foi uma das causas da perda de relevante capacidade tampão do sistema, resultando em pior desempenho do reator com relação à remoção de matéria orgânica e sulfato. 


\subsubsection{Considerações finais relativas à alcalinidade devida a sulfeto}

Em sistemas de tratamento biológico de águas residuárias ricas em sulfato, operadas na faixa de pH neutra, a capacidade tampão do meio é dependente tanto do íon bicarbonato quando do sulfeto total dissolvido produzido pelo metabolismo das BRS. Nesse contexto, é importante levar em conta a fração de alcalinidade fornecida pelo ânion $\mathrm{HS}^{-}$, a qual é titulada em conjunto com o bicarbonato. De outro modo, a capacidade tampão real do reator seria mascarada, levando a decisões equivocadas na operação do reator. Por exemplo, caso uma estratégia para a remoção do sulfeto dissolvido seja aplicada, a perda de alcalinidade devida à perda do $\mathrm{HS}^{-}$deve ser avaliada, ou a queda da alcalinidade no meio líquido poderia resultar na acidificação e no colapso do sistema.

Por outro lado, sistemas em que a presença de alcalinidade a sulfeto não é considerada também podem levar à superestimação da quantidade de bicarbonato produzido pelo metabolismo das BRS, implicando em conclusões enganosas sobre as vias metabólicas envolvidas ou a respeito da robustez do sistema. Este fato se torna mais relevante sob altas concentrações de HS .

É difícil separar a participação real de cada sistema tampão $\left(\mathrm{H}_{2} \mathrm{~S} / \mathrm{HS}^{-}\right.$e $\left.\mathrm{HCO}_{3}{ }^{-} / \mathrm{CO}_{2}\right)$ da alcalinidade total medida por titulometria. Isso pode ser explicado devido à proximidade entre os valores de pKa para os respectivos pares (6,99 e 6,30). No entanto, o cálculo teórico proposto para estimar a alcalinidade a sulfeto e a bicarbonato provou ser adequado para prever a quantidade de alcalinidade devido ao bissulfeto $\left(\mathrm{HS}^{-}\right)$em efluentes de reatores sulfetogênicos.

Uma avaliação geral dos resultados obtidos pelo DFSBR tratando a mistura de DAM e vinhaça sintéticas mostrou que a concentração de STD da ordem de $430 \mathrm{mg} . \mathrm{L}^{-1} \mathrm{em} \mathrm{pH}=8,48$ $\left(424 \mathrm{mgHS}^{-} . \mathrm{L}^{-1}\right)$ proporcionou uma alcalinidade de $642 \mathrm{mgCaCO}_{3} \cdot \mathrm{L}^{-1}$ exclusivamente devido ao bissulfeto. Além disso, pode-se observar que o aumento na dosagem de ferro resultou na 
redução das concentrações de alcalinidade total do sistema, causada pela precipitação de sulfetos de ferro, o que confirmou a validade da Sub-hipótese 1C: $O$ sulfeto dissolvido, devido às propriedades da sua especiação química, contribui expressivamente com a capacidade tampão de reatores sulfetogênicos, de forma que a sua diminuição gradual, induzida pelo aumento na carga de ferro aplicada, será uma das principais causas da perda de alcalinidade do sistema. 


\subsection{ETAPA 2: Influência da recirculação no DFSBR}

A ETAPA 2 foi dedicada à avaliação da influência de diferentes razões de recirculação e suas velocidades superficiais de escoamento sobre o padrão hidrodinâmico do reator DFSBR e sobre o desempenho do sistema no tratamento de DAM em co-digestão com vinhaça de cana-de-açúcar concentrada, com vistas também ao estabelecimento de melhores condições para a formação e sedimentação de sulfetos metálicos (Objetivo específico 2: Subhipóteses 2A e 2B).

\subsubsection{Caracterização hidrodinâmica do DFSBR sob diferentes razões de reciclo}

Antes de proceder à inoculação do material suporte e ao início da operação do reator DFSBR, um ensaio hidrodinâmico em degrau foi realizado utilizando $\mathrm{KCl}$ como traçador para caracterizar o escoamento do reator na ausência de recirculação, biofilme e produção de biogás. Esse ensaio foi assumido como a condição controle. O DFSBR foi inoculado com a mistura de dois lodos anaeróbios, conforme descrito na seção 4.4, p. 68, e passou a operar, no início da ETAPA 2, alimentado com meio sintético simulando a fração solúvel da vinhaça, em condições iguais à ETAPA 1, sem adição de cloreto ferroso. Durante esse período foram realizados ensaios hidrodinâmicos conforme a metodologia apresentada na seção 4.8, p. 88, tendo sido testadas quatro diferentes razões de recirculação da fase líquida, as quais resultaram em diferentes velocidades superficiais de escoamento. Após os ensaios hidrodinâmicos, o reator passou a ser alimentado com vinhaça real como doador de elétrons, e as diferentes razões de recirculação foram aplicadas alternadamente para avaliar o desempenho do DFSBR em cada uma delas. 
A Figura 5.18 apresenta as curvas de resposta normalizadas (curvas F originais Figura 5.18.a), as curvas de resposta ajustadas às curvas polinomiais ou sigmoidais para minimização dos ruídos observados na resposta da sonda (curvas F ajustadas - Figura 5.18.b) e as curvas de distribuição do tempo de residência (curvas E - Figura 5.18.c). 
(a)

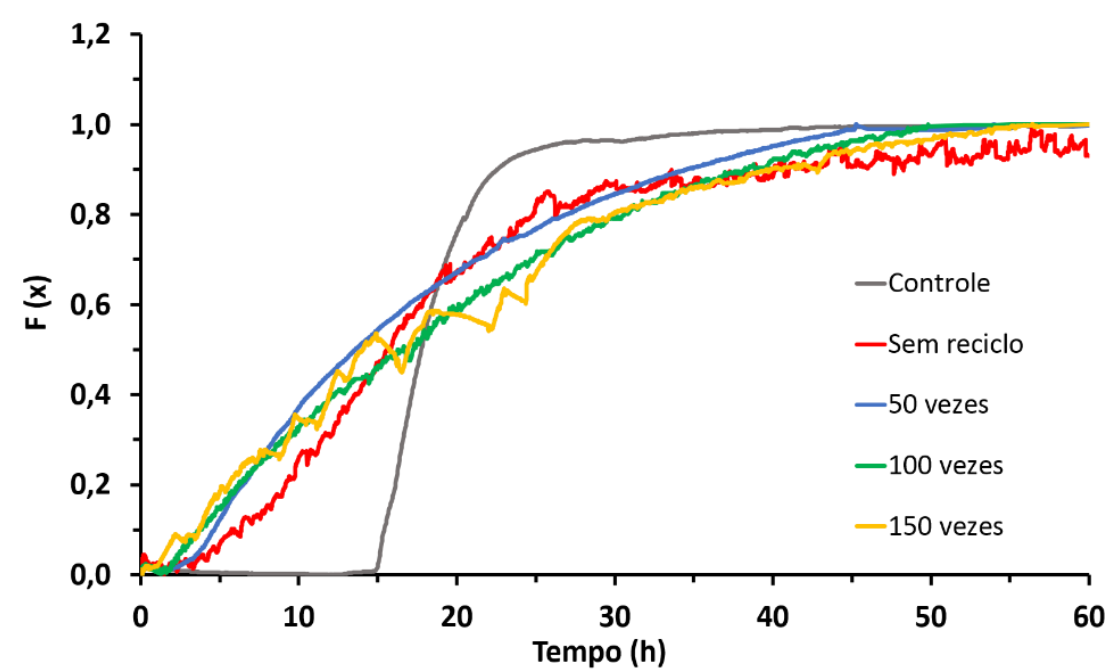

(b)

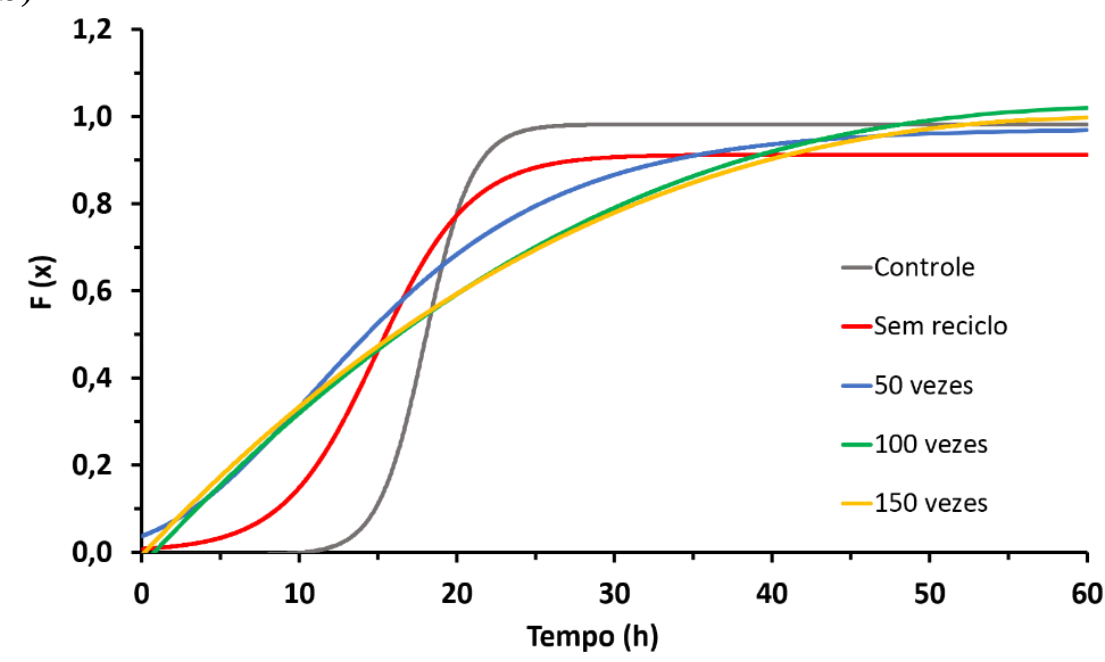

(c)

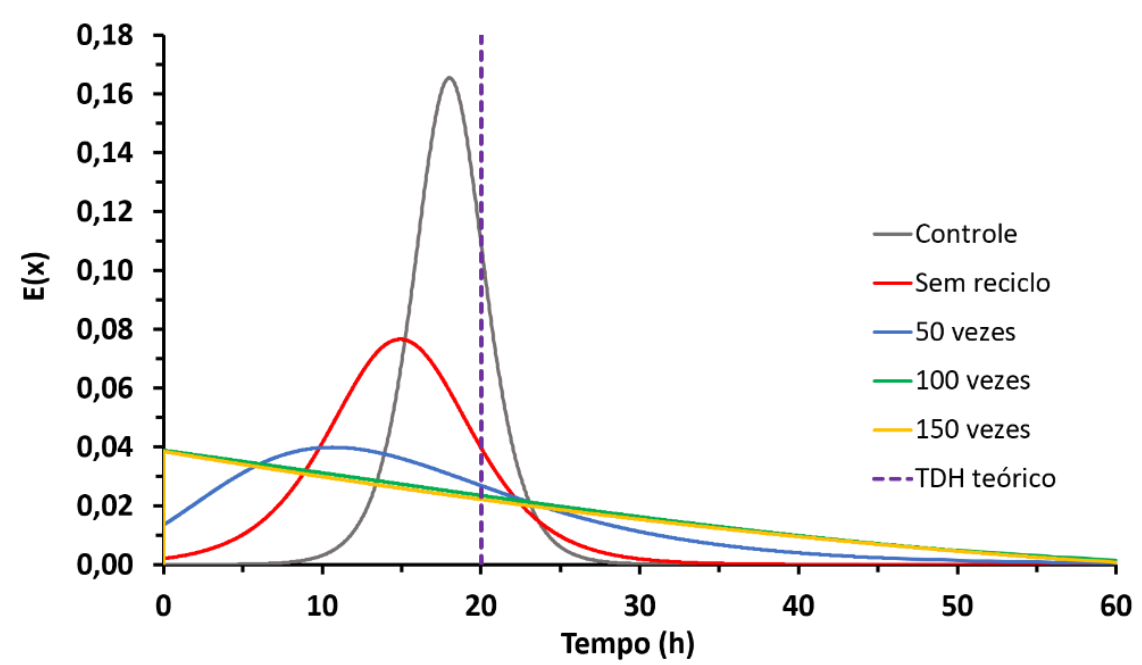

Figura 5.18. Resultados dos ensaios hidrodinâmicos: (a) Curvas de resposta normalizadas obtidas (curvas F originais); (b) Curvas de resposta ajustadas (curvas F ajustadas); e (c) Curvas de distribuição do tempo de residência (curvas E).

Fonte: $\mathrm{O}$ autor. 
As curvas de resposta dos ensaios controle e sem recirculação foram ajustadas a sigmoides de Boltzmann. A curva de resposta do ensaio com reciclo de 50 vezes foi ajustada à sigmoide de Gompertz. Já as outras curvas de resposta (razões de reciclo de 100 e 150 vezes) foram ajustadas a funções polinomiais de quarto grau. As equações obtidas com seus respectivos coeficientes de correlação estão explicitadas na Tabela 5.6.

Tabela 5.6. Ajustes matemáticos das curvas de resposta obtidas.

\begin{tabular}{lllll}
\hline $\begin{array}{l}\text { Condição } \\
\text { do ensaio }\end{array}$ & $\begin{array}{l}\text { Razão de } \\
\text { reciclo }\end{array}$ & $\begin{array}{l}\text { Ajuste } \\
\text { efetuado }\end{array}$ & Equação da curva & $\mathbf{R}^{2}$ \\
\hline Abiótico & $0 \mathrm{x}$ & $\begin{array}{l}\text { Sigmoide de } \\
\text { Boltzmann }\end{array}$ & $y=\frac{-0,006-0,982}{1+e^{(x-17,992) / 1,493}}-0,982$ & 0,997 \\
\hline & $0 \mathrm{x}$ & $\begin{array}{l}\text { Sigmoide de } \\
\text { Boltzmann }\end{array}$ & $y=\frac{0,0015-0,912}{1+e^{(x-14,909) / 2,972}}-0,912$ & 0,992 \\
$\begin{array}{l}\text { Reator em } \\
\text { operação } \\
\text { contínua }\end{array}$ & $50 \mathrm{x}$ & $\begin{array}{l}\text { Sigmoide de } \\
\text { Gompertz }\end{array}$ & $y=0,972 \cdot e^{-e^{(-0,1115(x-10,6374))}}$ & 0,993 \\
& $100 \mathrm{x}$ & $\begin{array}{l}\text { Polinomial de } \\
4^{\circ} \text { grau }\end{array}$ & $y=-0,031+0,039 x-3,75 \cdot 10^{-4} x^{2}-$ & 0,999 \\
\hline & $150 \mathrm{x}$ & $\begin{array}{l}\text { Polinomial de } \\
4^{\circ} \text { grau }\end{array}$ & $y=-0,007+0,038 x-4,51 \cdot 10^{-4} x^{2}+$ & 0,993 \\
\hline
\end{tabular}

Fonte: $\mathrm{O}$ autor.

Além da determinação do tempo de detenção hidráulica real, os dados obtidos pelos ensaios hidrodinâmicos foram ajustados ao modelo de $\mathrm{N}$ tanques de mistura completa em série, bem como foi calculada em cada caso o número de dispersão longitudinal observado (D/u.L). Esses resultados estão resumidos na Tabela 5.7. 
Tabela 5.7. Características do escoamento no DFSBR sob diferentes razões de recirculação.

\begin{tabular}{lllll}
\hline $\begin{array}{l}\text { Condição } \\
\text { do ensaio }\end{array}$ & $\begin{array}{l}\text { Razão de } \\
\text { reciclo }\end{array}$ & $\begin{array}{l}\text { TDH real } \\
\text { (h) }\end{array}$ & $\mathbf{N}$ & D/ $\boldsymbol{\mu . L}$ \\
\hline Abiótico & $0 \mathrm{x}$ & 18 & 44,3 & 0,01 \\
\hline & $0 \mathrm{x}$ & 15 & 8,4 & 0,06 \\
$\begin{array}{l}\text { Reator em } \\
\text { operação } \\
\text { contínua }\end{array}$ & $50 \mathrm{x}$ & 16 & 2,6 & 0,19 \\
& $100 \mathrm{x}$ & 18 & 2,0 & 0,26 \\
\hline
\end{tabular}

Fonte: $\mathrm{O}$ autor.

$\mathrm{Na}$ condição controle, ou seja, testada na ausência de atividade biológica, o reator DFSBR apresentou TDH real de $18 \mathrm{~h}, 10 \%$ menor que o TDH nominal teoricamente imposto pela vazão afluente. Menores valores de TDH reais também foram observados nos ensaios realizados com o reator em operação contínua, como mostrado na Tabela 5.7. O adiantamento do TDH real em reatores pode ser atribuído à presença de regiões de estagnação, as quais não contribuem para o volume útil reacional do sistema (LEVENSPIEL, 2000). Uma vez que o DFSBR conta com uma zona cônica inferior sem a presença de material suporte para facilitar a sedimentação dos sulfetos metálicos, tal região pode ser a responsável pelo estabelecimento de caminhos preferenciais de escoamento, implicando nos menores TDHs reais observados.

Para comprovar essa hipótese, um pulso de $50 \mathrm{~mL}$ de solução de dextrana azul, corante com elevado peso molecular $\left(2 \times 10^{6} \mathrm{~g} \cdot \mathrm{mol}^{-1}\right)$, foi efetuado na zona de entrada superior do DFSBR, para visualização do escoamento e identificação das zonas mortas mais relevantes do sistema. O registro fotográfico do experimento é mostrado na Figura 5.19. 
(a)

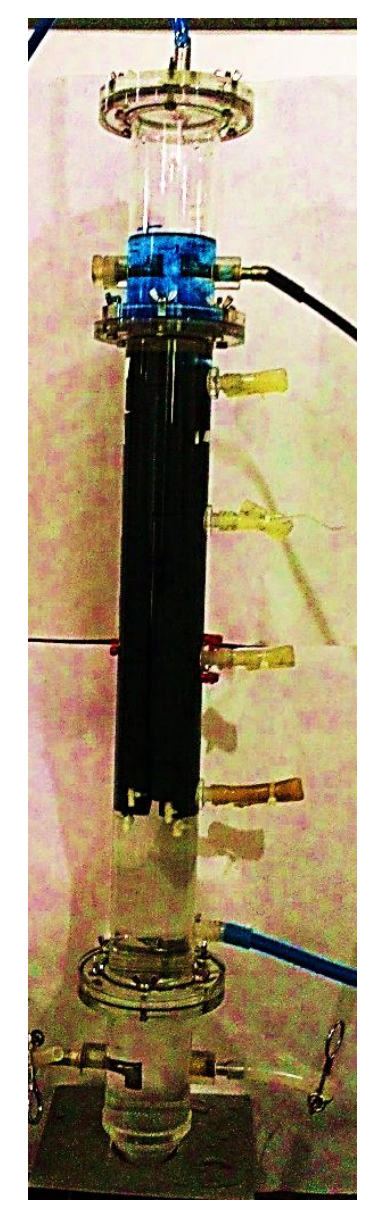

(b)

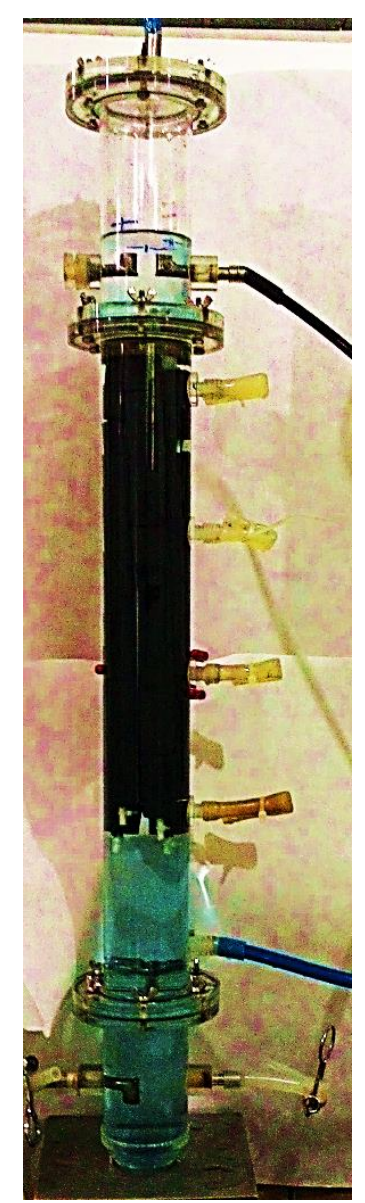

(c)

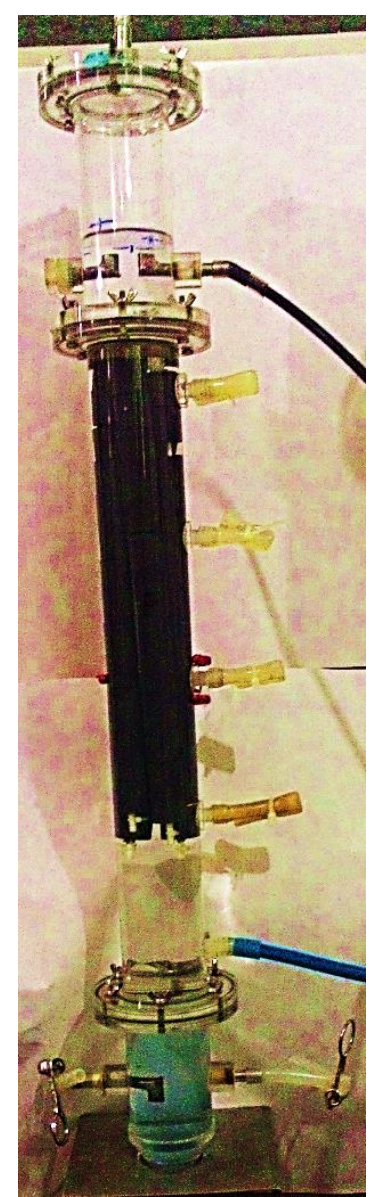

Figura 5.19. Fotografias mostrando a injeção de dextrana azul no DFSBR: (a) Logo após o pulso; (b) após 6 h do pulso; e (c) após 24 h. As imagens receberam tratamento digital para melhor visualização da zona estagnada (em azul).

Fonte: $\mathrm{O}$ autor.

Apesar da solução contendo a dextrana azul ter sido preparada com densidade de 1029 g.L $\mathrm{L}^{-1}$, próxima da densidade da água de abastecimento utilizada para preencher o reator (1028 g.L $\left.\mathrm{L}^{-1}\right)$, o pulso de dextrana não acompanhou adequadamente o escoamento descendente, tendo se espalhado rapidamente por todo o leito do reator. Em todo caso, após passado o TDH nominal de $20 \mathrm{~h}$ a dextrana ainda permanecia acumulada na região de sedimentação na base do DFSBR (Figura 5.19.c), indicando a presença de uma importante zona morta nessa região.

Embora esse fator implique na obtenção de um tempo de detenção menor que o nominal, esse último dado pela vazão da corrente afluente do reator, essa observação já era 
esperada, uma vez que a zona de sedimentação foi introduzida no DFSBR para promover justamente a sedimentação e o acúmulo dos sulfetos metálicos precipitados. A estagnação do escoamento nessa região do reator é necessária para evitar a ressuspensão do material precipitado e o seu arraste junto com a corrente efluente do reator, o que prejudicaria uma eficiente retenção dos sulfetos metálicos.

Ao longo dos ensaios hidrodinâmicos realizados com o reator em operação contínua, alimentado com meio sintético, TDHs reais ainda menores foram determinados no caso do reator operado sem reciclo ( $15 \mathrm{~h}$ ) e com razão de reciclo de 50 vezes ( $16 \mathrm{~h})$. No caso do reator operando com razões de reciclo de 100 e 150 vezes, os TDHs reais medidos foram de 18 e 19 h, respectivamente (Tabela 5.7). Uma explicação para essas observações seria a de que, após a inoculação do material suporte, a formação de uma camada de biofilme na superfície e no interior dos módulos de polietileno, utilizados como material suporte, pode ter resultado na diminuição do volume útil do sistema. Ao final da operação, a parte interior de alguns módulos de polietileno mostraram ainda sinais de entupimento pelo lodo introduzido no reator (dados não mostrados). Já para os ensaios testando maiores razões de recirculação, a turbulência advinda das altas velocidades do escoamento superficial podem ter resultado em uma maior participação da zona inferior do reator no volume útil do sistema, o que depois será relacionado com as menores eficiência de retenção de sulfetos de ferro obtidas nessas condições (subseção 5.3.4, p. 171).

A modelação do escoamento do reator utilizando o modelo uniparamétrico de $\mathrm{N}$ tanques de mistura completa em série resultou em 44,3 tanques em série no caso da condição controle, o que indica a característica do escoamento do DFSBR tendendo a pistonado ideal, uma vez que é usual considerar, para fins práticos, reatores com $\mathrm{N}>30$ dessa forma (LEVENSPIEL, 2000). Todavia, no caso do reator em operação, o $\mathrm{N}$ decresceu para 8,4 mesmo na ausência de reciclo (Tabela 5.7). A hipótese levantada para explicar essa 
observação foi a de que a produção de biogás implicou em maior turbulência no escoamento do reator, levando ao maior padrão de mistura observado. Isso principalmente pelo deslocamento do biogás se dar no sentindo ascendente, inversamente ao sentido do escoamento da fase líquida.

Com o aumento da razão de reciclo também o padrão de mistura no interior do DFSBR aumentou, como já era esperado, resultando em menores valores de N, o qual chegou a valor próximo de 1 no caso da razão de reciclo igual a 150 vezes a vazão afluente. Nessa condição, o DFSBR pode ser modelado como um reator de mistura perfeita (LEVENSPIEL, 2000).

As características do padrão de escoamento do DFSBR foram confirmadas pelo modelo de dispersão longitudinal, uma vez que para a condição controle (sem biomassa ativa) a relação $\mathrm{D} / \mu$.L foi de 0,01 , o que configura um escoamento de baixa dispersão. Já nas condições sob operação contínua, a produção de biogás no reator levou ao aumento da dispersão longitudinal, a qual alcançou valores maiores quanto maiores foram as razões de reciclo aplicadas (Tabela 5.7).

\subsubsection{Desempenho do DFSBR sob diferentes razões de recirculação}

A Figura 5.20 apresenta o desempenho geral do DFSBR na remoção de matéria orgânica e sulfato ao longo da ETAPA 2. Ao início da FASE 2A, após a realização do primeiro ensaio hidrodinâmico em condições abióticas, o reator foi inoculado (seção 4.4) e passou a ser alimentado com vinhaça real como fonte de carbono e doador de elétrons para a sulfetogênese. Apenas da FASE 2B em diante efetuou-se a introdução de DAM sintética, com carga volumétrica de ferro aplicada (CFVa) mantida entre 0,5 e $0,7 \mathrm{gFe}^{2+} \cdot \mathrm{L}^{-1} \cdot \mathrm{d}^{-1}$. Variações na vazão de entrada da solução de cloreto ferroso implicaram em concentrações afluentes de 
ferro da ordem de $250 \mathrm{mg} . \mathrm{L}^{-1}$ durante a FASE 2B, e de cerca de $350 \mathrm{mg} . \mathrm{L}^{-1}$ durante as outras as fases $(2 \mathrm{C}$ a $2 \mathrm{E})$.

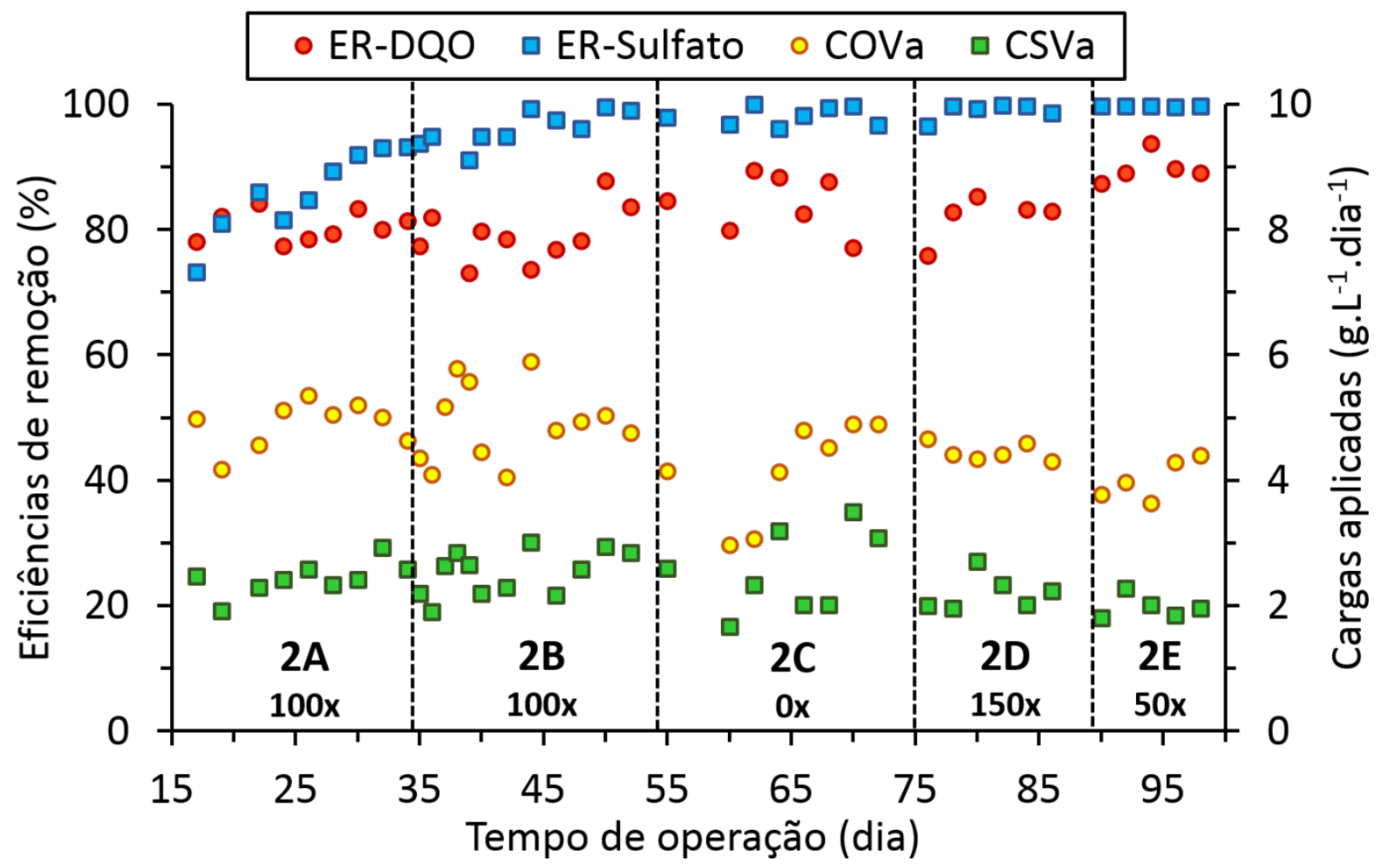

Figura 5.20. Eficiências de remoção de DQO (ER-DQO) e sulfato (ER-Sulfato), e cargas volumétricas aplicadas de matéria orgânica (COVa) e sulfato (CSVa) ao longo do tempo de operação da ETAPA 2, sob diferentes razões de recirculação.

Fonte: $\mathrm{O}$ autor.

Durante a ETAPA 2 o sistema foi operado com carga orgânica volumétrica média (COVa) de 4,6 \pm 0,6 gDQO. $\mathrm{L}^{-1} \cdot \mathrm{d}^{-}{ }^{1}$ e carga de sulfato volumétrica de (CSVa) 2,3 \pm 0,4 g. $\mathrm{L}^{-1} \cdot \mathrm{d}^{-1}$. Cargas orgânicas volumétricas removidas (COVr) da ordem de 3,7 gDQO.L $\mathrm{L}^{-1} \cdot \mathrm{d}^{-1} \mathrm{e}$ cargas volumétricas removidas de sulfato (CSVr) acima de 2,0 $\mathrm{gSO}_{4}{ }^{2-} \cdot \mathrm{L}^{-1} \cdot \mathrm{d}^{-1}$ foram observadas ao longo da ETAPA 1. Os valores médios referentes a esses parâmetros em cada FASE com seus respectivos desvios-padrões estão apresentados na Tabela 5.8. 
Tabela 5.8. Cargas orgânicas volumétricas aplicadas (COVa) e removidas (COVr), cargas de sulfato volumétricas aplicadas (CSVa) e removidas (CSVr) e eficiências de remoção de DQO (ER-DQO) e sulfato (ER-Sulfato) obtidas durante a ETAPA 2.

\begin{tabular}{|c|c|c|c|c|c|c|}
\hline \multirow{2}{*}{$\begin{array}{c}\text { FASES } \\
2 \mathrm{~A}\end{array}$} & \multicolumn{2}{|c|}{$\left(\right.$ gDQO.L $\left.L^{-1} . d^{-1}\right)$} & \multirow{2}{*}{$\begin{array}{c}\text { ER-DQO } \\
(\%) \\
80 \pm 2\end{array}$} & \multicolumn{2}{|c|}{$\left(\mathrm{gSO}_{4}{ }^{2-} \cdot \mathrm{L}^{-1} \cdot \mathrm{d}^{-1}\right)$} & \multirow{2}{*}{$\begin{array}{c}\text { ER-Sulfato } \\
(\%) \\
87 \pm 5\end{array}$} \\
\hline & $4,9 \pm 0,4$ & $3,9 \pm 0,3$ & & $2,4 \pm 0,3$ & $2,1 \pm 0,3$ & \\
\hline $2 B$ & $4,9 \pm 0,6$ & $3,8 \pm 0,4$ & $79 \pm 4$ & $2,5 \pm 0,4$ & $2,4 \pm 0,3$ & $95 \pm 4$ \\
\hline $2 \mathrm{C}$ & $4,2 \pm 0,8$ & $3,6 \pm 0,5$ & $82 \pm 8$ & $2,5 \pm 0,7$ & $2,6 \pm 0,6$ & $98 \pm 2$ \\
\hline $2 \mathrm{D}$ & $4,5 \pm 0,1$ & $3,5 \pm 0,3$ & $80 \pm 7$ & $2,2 \pm 0,3$ & $2,3 \pm 0,4$ & $99 \pm 1$ \\
\hline $2 \mathrm{E}$ & $4,0 \pm 0,3$ & $3,6 \pm 0,3$ & $90 \pm 2$ & $2,0 \pm 0,2$ & $2,0 \pm 0,2$ & $100 \pm 1$ \\
\hline
\end{tabular}

Fonte: $\mathrm{O}$ autor.

Com a introdução de vinhaça (4000 $\left.\pm 440 \mathrm{mgDQO} . \mathrm{L}^{-1}\right)$ durante a ETAPA 2, o DFSBR apresentou eficiências de remoção de DQO próximas de $80 \%$ ao longo das FASES 2A a 2D, e eficiência média de $90 \pm 2 \%$ durante a FASE 2E (Figura 5.21.a). As eficiências de remoção de DQO obtidas durante a ETAPA 2 foram inferiores às alcançadas pelo DFSBR tratando vinhaça sintética (ETAPA 1 - ER-DQO = $94 \pm 2 \%$ ), consequência da maior complexidade do efluente real utilizado. De fato, a vinhaça de cana-de-açúcar contém alta variabilidade de substâncias orgânicas de difícil degradação, tais como diferentes compostos aromáticos, furfurais e melanoidinas (FUESS; GARCIA, 2014), o que resulta em maior concentração de matéria orgânica residual após o tratamento anaeróbio, como mostrado pela Figura 5.22. 
(a)

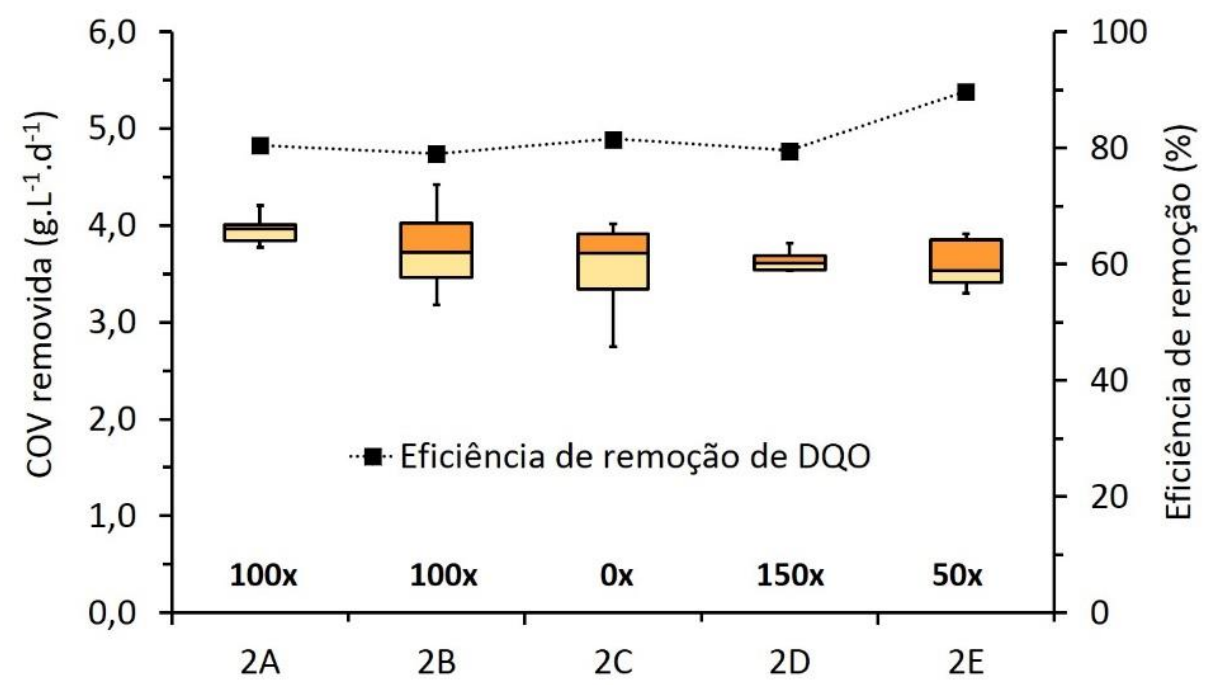

(b)

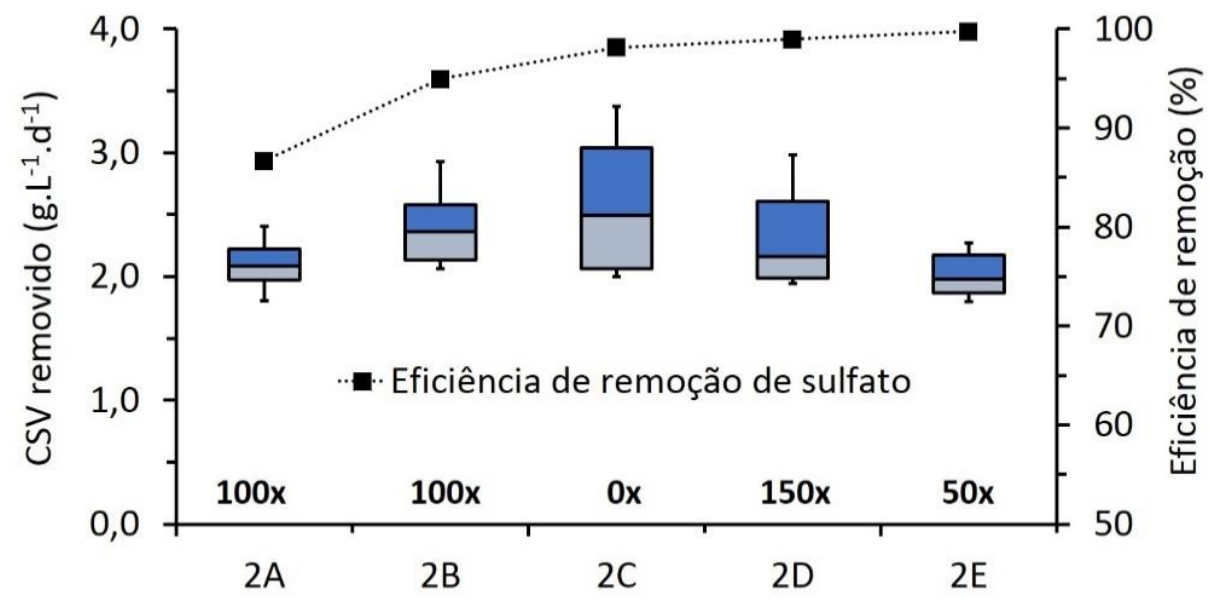

Figura 5.21. Desempenho geral do DFSBR: (a) Análise estatística de Boxplot das cargas orgânicas removidas (COVr) e eficiências médias de remoção de DQO durante a ETAPA 2; e (b) Análise estatística de Boxplot das cargas de sulfato removidas (CSVr) e eficiências médias de remoção de sulfato durante a ETAPA 2.

Fonte: $\mathrm{O}$ autor. 


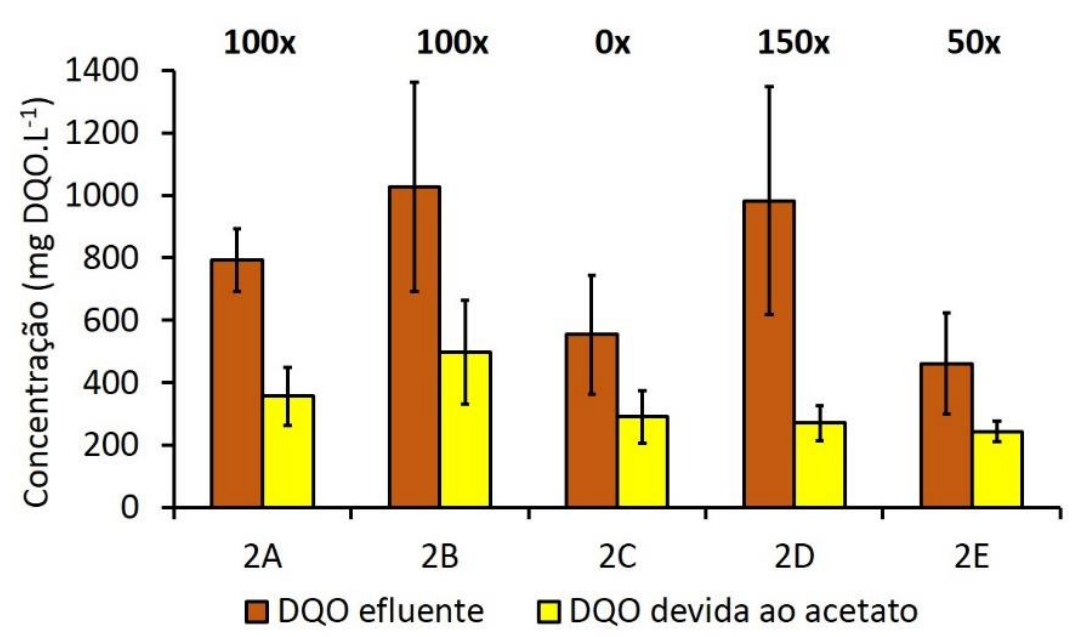

Figura 5.22. Concentrações de ácido acético (em termos de DQO) no efluente do reator DFSBR durante as fases operacionais da ETAPA 2. As barras de erro representam o desvio-padrão.

Fonte: $\mathrm{O}$ autor.

Com relação à remoção de sulfato, o DFSBR foi capaz de atingir eficiências crescentes ao longo da ETAPA 2 (Figura 5.21.b), com eficiências médias de $87 \pm 5 \%$ durante a FASE 2A, $95 \pm 4 \%$ durante a FASE 2B, após o início da introdução de ferro no sistema, e eficiências próximas de $100 \%$ durante as fases subsequentes, com sulfato residual no efluente abaixo de $2 \mathrm{mg} . \mathrm{L}^{-1}$ (limite de detecção do método turbidimétrico). Assim, após a introdução da DAM sintética, as eficiências de remoção de sulfato aumentaram, fato este que já havia sido observado durante a ETAPA 1, confirmando a hipótese de que a precipitação do sulfeto favorece a sulfetogênese pela minimização da exposição da biomassa aos efeitos tóxicos desse composto. Com o aumento da sulfetogênese, maiores concentrações de ácido acético no efluente também ocorreram na FASE 2B (cerca de 300 até $700 \mathrm{mgDQO} . \mathrm{L}^{-1}$ ), decrescendo em seguida (Figura 5.22). Outros ácidos orgânicos e álcoois não foram detectados do efluente. Diferenças estatisticamente significativas $(\mathrm{P}<0,05)$ relativas às eficiências de remoção de sulfato só foram identificadas na FASE 2A (sem dosagem de cloreto ferroso) em relação às outras fases operacionais da ETAPA 2, comprovando o real efeito positivo da precipitação do sulfeto sobre os processos de redução de sulfato. 
A dispersão expressiva nos dados relativos à carga de sulfato removida (CSVr) notada durante as FASES 2B, 2C e 2D, devido às variações na CSVa (Figura 5.21), pode estar relacionada com a dificuldade em se obter a dissolução adequada do sulfato de sódio na vinhaça durante o preparo da alimentação do reator. No entanto, o sistema foi capaz de suportar essa inconstância na dosagem do sulfato afluente, não apresentando variações pronunciadas de suas eficiências de remoção de sulfato em cada uma dessas fases (Figura $5.20)$.

As altas eficiências de remoção de sulfato obtidas pelo DFSBR ao longo dessa etapa (Tabela 5.8) confirmaram a possibilidade da utilização da vinhaça de cana-de-açúcar como doador de elétrons para a redução de sulfato no tratamento de uma drenagem ácida sintética, da mesma forma como observado por GONÇALVES et al. (2007). A diversidade de componentes orgânicos presentes na vinhaça (WILKIE et al., 2000) associada ao metabolismo versátil das BRS, as quais são capazes de utilizar uma ampla gama de substratos (LIAMLEAM; ANNACHHATRE, 2007), devem ter sido os fatores determinantes para o sucesso do processo.

Assim, as diferentes recirculações aplicadas durantes a ETAPA 2 (Tabela 4.1) não influenciaram o processo de remoção de sulfato. Já com relação à eficiência de remoção de DQO, apenas a FASE 2E apresentou diferença estatística $(\mathrm{p}<0,05)$ em relação às outras fases. Nessa última fase operacional, o reator operou com razão de reciclo da ordem de 50 vezes a vazão afluente, com eficiência de remoção de DQO da ordem de $90 \%$, o que foi superior aos cerca de $80 \%$ alcançados durante as outras fases (Figura 5.21.a). É importante notar que, durante as fases com as menores razões de recirculação aplicadas (FASES 2C e 2E), menores concentrações residuais de DQO no efluente também foram obtidas (Figura 5.22). Esse resultado permite supor que altas razões de reciclo (100 e 150 vezes) prejudicaram a completa degradação da matéria orgânica devido ao stress causado sobre a biomassa pelas 
forças de cisalhamento intensificadas $\left(V_{S}\right.$ de 3,50 a 5,20 m.h $\left.{ }^{-1}\right)$. Por outro lado, a taxa de reciclo de 50 vezes proporcionou uma velocidade superficial de escoamento otimizada $\left(1,75 \mathrm{~m} \cdot \mathrm{h}^{-1}\right)$, a qual favoreceu a maior remoção de matéria orgânica observada, o que pode ser atribuído à minimização da limitação à transferência de massa no sistema (MOHAN et al., 2007; RAMOS et al., 2003; CAMARGO et al., 2002).

A Figura 5.23 apresenta o balanço de matéria orgânica consumida (em termos de fluxo de elétrons) pelas vias sulfetogênica e metanogênica.

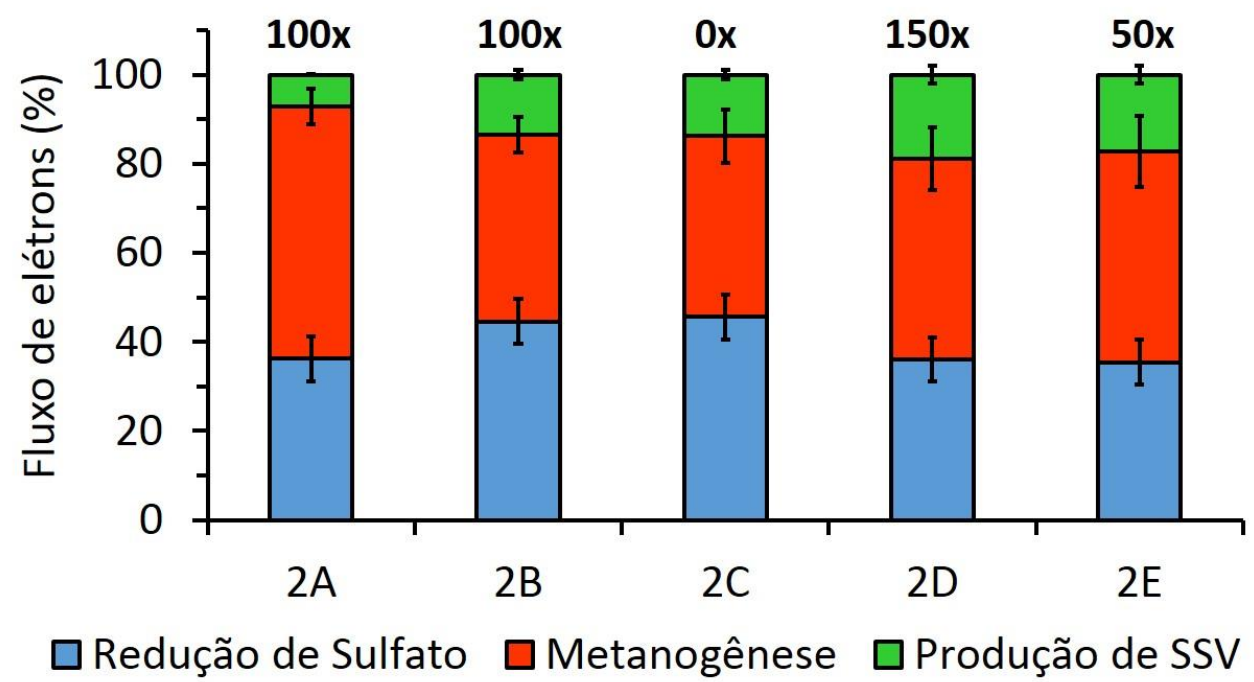

Figura 5.23. Distribuição do fluxo de elétrons no DFSBR (em porcentagem de DQO) para as vias de redução de sulfato, metanogênese e produção de sólidos suspensos voláteis (SSV) em cada fase da ETAPA 2. As barras de erros representam o desvio-padrão.

Fonte: $\mathrm{O}$ autor.

Durante a FASE 2A, operada sem adição da DAM sintética e com razão de reciclo da ordem de 100 vezes $\left(\mathrm{V}_{\mathrm{S}}=3,50 \mathrm{~m} \cdot \mathrm{h}^{-1}\right)$, a sulfetogênese foi responsável por $36 \%$ da DQO removida, enquanto que a metanogênese predominou, sendo responsável por $56 \%$ da DQO removida nessa fase. Após a introdução da DAM sintética ocorreu o aumento da contribuição da sulfetogênese para à remoção de DQO, cuja participação passou para $42 \%$ e $50 \%$ durante as FASES 2B $\left(\mathrm{V}_{\mathrm{S}}=3,50 \mathrm{~m} \cdot \mathrm{h}^{-1}\right)$ e $2 \mathrm{C}\left(\mathrm{V}_{\mathrm{S}}=0,03 \mathrm{~m} \cdot \mathrm{h}^{-1}\right)$, respectivamente. A ausência de 
recirculação durante a FASE 2C, portanto, proporcionou a maior participação da sulfetogênese no processo global de remoção de matéria orgânica, em detrimento da metanogênese. Já durante as FASES $2 \mathrm{D}$ e 2E, com razões de reciclo de 150 vezes $\left(\mathrm{V}_{\mathrm{S}}=\right.$ $\left.5,20 \mathrm{~m} \cdot \mathrm{h}^{-1}\right)$ e 50 vezes $\left(\mathrm{V}_{\mathrm{S}}=1,75 \mathrm{~m} \cdot \mathrm{h}^{-1}\right)$, respectivamente, observou-se uma diminuição da participação da sulfetogênese para cerca de $40 \%$ em ambas as fases, enquanto que a metanogênese foi favorecida, sendo responsável por cerca de 50\% da DQO removida.

Esse resultado pode estar diretamente relacionado com a distribuição espacial dos microrganismos metanogênicos e redutores de sulfato ao longo da espessura do biofilme. Enquanto as BRS podem ser encontradas nas camadas mais superficiais, as AM se estabelecem preferencialmente nas regiões mais profundas (SUN et al., 2014; SANTEGOEDS et al., 1999). Dessa forma, a aplicação de maiores velocidades superficiais de escoamento promovem uma melhor transferência de massa, favorecendo o metabolismo das populações metanogênicas no interior do biofilme. Por outro lado, essas maiores velocidades superficiais implicam em forças de cisalhamento intensificadas, com prejuízo para as populações de bactérias presentes nas zonas mais superficiais do biofilme. De fato, as altas razões de reciclo, apesar de não implicarem em queda significativa na eficiência de remoção de sulfato no reator, ocasionaram o aumento da concentração de SSV no efluente (Tabela 5.9), concomitantemente ao aumento da DQO solúvel residual (Figura 5.22).

Tabela 5.9. Concentrações de SSV medido no efluente do DFSBR durante a ETAPA 2.

\begin{tabular}{llll}
\hline $\begin{array}{l}\text { Fase } \\
\text { Operacional }\end{array}$ & $\begin{array}{l}\text { Razão de } \\
\text { reciclo }\end{array}$ & $\begin{array}{l}\text { Velocidade } \\
\text { superficial }\left(\mathbf{m . h}^{-\mathbf{1}}\right)\end{array}$ & $\begin{array}{l}\text { SSV no efluente } \\
\left(\mathbf{m g . L ^ { - 1 }}\right)\end{array}$ \\
\hline 2A & $100 \mathrm{x}$ & 3,50 & $200 \pm 90$ \\
\hline 2B & $100 \mathrm{x}$ & 3,50 & $350 \pm 130$ \\
\hline 2C & $0 \mathrm{x}$ & 0,03 & $290 \pm 120$ \\
\hline 2D & $150 \mathrm{x}$ & 5,20 & $580 \pm 340$ \\
\hline E & $50 \mathrm{x}$ & 1,75 & $500 \pm 100$ \\
\hline
\end{tabular}

Fonte: $\mathrm{O}$ autor. 
De fato, com relação à quantia de sólidos suspensos voláteis (SSV) identificada no efluente do DFSBR, notou-se um aumento na produção de SSV de cerca de $200 \mathrm{mg} . \mathrm{L}^{-1}$ (FASE 2A) para próximo de $350 \mathrm{mg} . \mathrm{L}^{-1}$ (FASE 2B), logo após a introdução da DAM sintética. Já durante a FASE 2C, operada sem recirculação da fase líquida, a concentração de SSV no efluente caiu para próximo de $290 \mathrm{mg} . \mathrm{L}^{-1}$. Durante a FASE 2D, operada com máxima razão de reciclo, os SSV no efluente foram da ordem de $580 \mathrm{mg} . \mathrm{L}^{-1}$. Após a diminuição da recirculação, o teor de sólidos suspensos voláteis voltou a cair, durante a FASE 2E, para cerca de $500 \mathrm{mg} \cdot \mathrm{L}^{-1}$. Assim, as altas velocidades superficiais aplicadas durante a FASE 2D estiveram associadas com as maiores perdas de biomassa (na forma de SSV) por arraste do escoamento observadas. Em consequência, uma maior assimilação de matéria orgânica pelo biofilme para repor a biomassa perdida deverá ser esperada (MICHAUD et al., 2003). Já durante a FASE 2E, embora a razão de reciclo tenha sido diminuída, houve apenas redução parcial da perda de SSV pelo DFSBR.

Análises gravimétricas efetuadas com amostras de material suporte ao final de cada fase operacional da ETAPA 2 mostraram que a massa de sólidos voláteis aderidos ao polietileno no DFSBR variou entre 14,3 e 18,7 g, sendo que a maior quantia de SV aderido foi identificada ao final da FASE 2C, operada sem reciclo (Figura 5.24.a). O mesmo padrão foi observado com relação à massa de sólidos fixos no lodo do material suporte, a qual variou de 4,4 a 8,4 g, sendo a maior quantia de SF encontrada também ao final da fase sem reciclo (Figura 5.24.a). Esse resultado comprovou que o aumento das velocidades superficiais do escoamento no DFSBR favoreceram o cisalhamento e o arraste do material aderido, enquanto que a ausência de recirculação promoveu um maior acúmulo de sólidos fixos e voláteis no material suporte, como já seria esperado. Esse comportamento pode estar relacionado à maior manutenção de biomassa aderida e ao acúmulo de sulfetos metálicos no biofilme. 
A caracterização elementar das amostras por EDX (Figura 5.24.b), por outro lado, indicou maiores proporções de ferro no lodo do material suporte ao final das FASES $2 \mathrm{~B}$ (25\%), 2D (24\%) e 2E (27\%), sendo que a FASE 2C, sem reciclo, foi a que apresentou a menor proporção de ferro no biofilme (20\%). Esse resultado pode ser o indicativo de que a presença de recirculação promoveu o retorno do material precipitado para a zona do reator com material suporte, favorecendo não só o arraste da biomassa pelo cisalhamento, mas também a deposição dos sulfetos metálicos sobre o biofilme. Nesse caso, problemas pela limitação à transferência de massa e por toxicidade poderiam vir a ser observados após longo tempo de operação (VILLA-GOMEZ et al., 2011; UTGIKAR et al., 2002). 
(a)

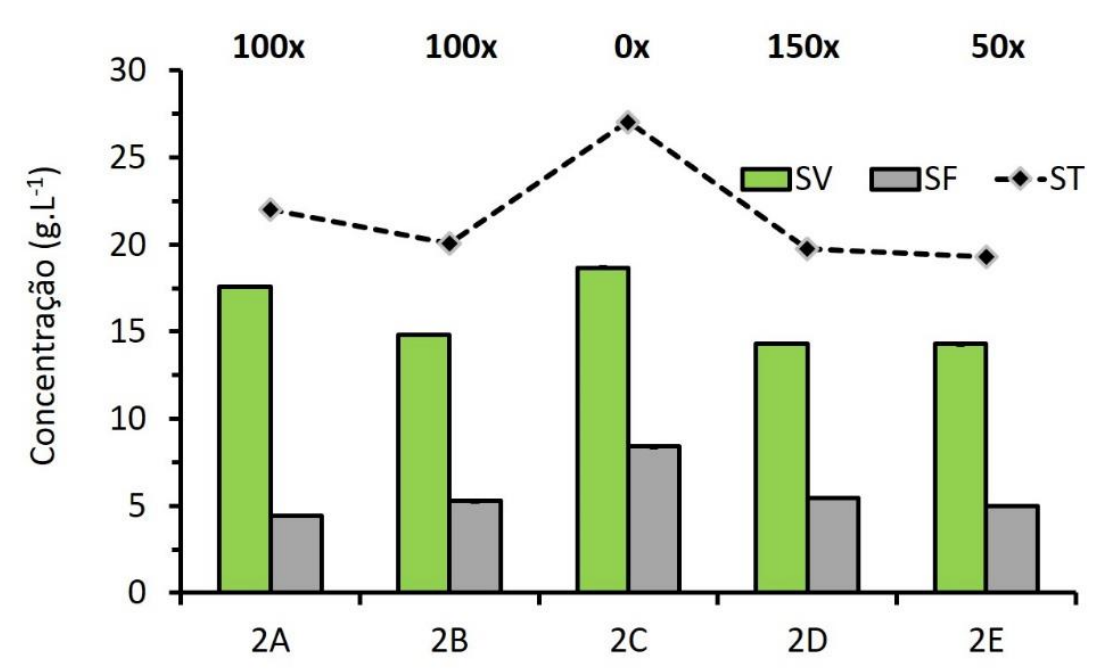

(b)

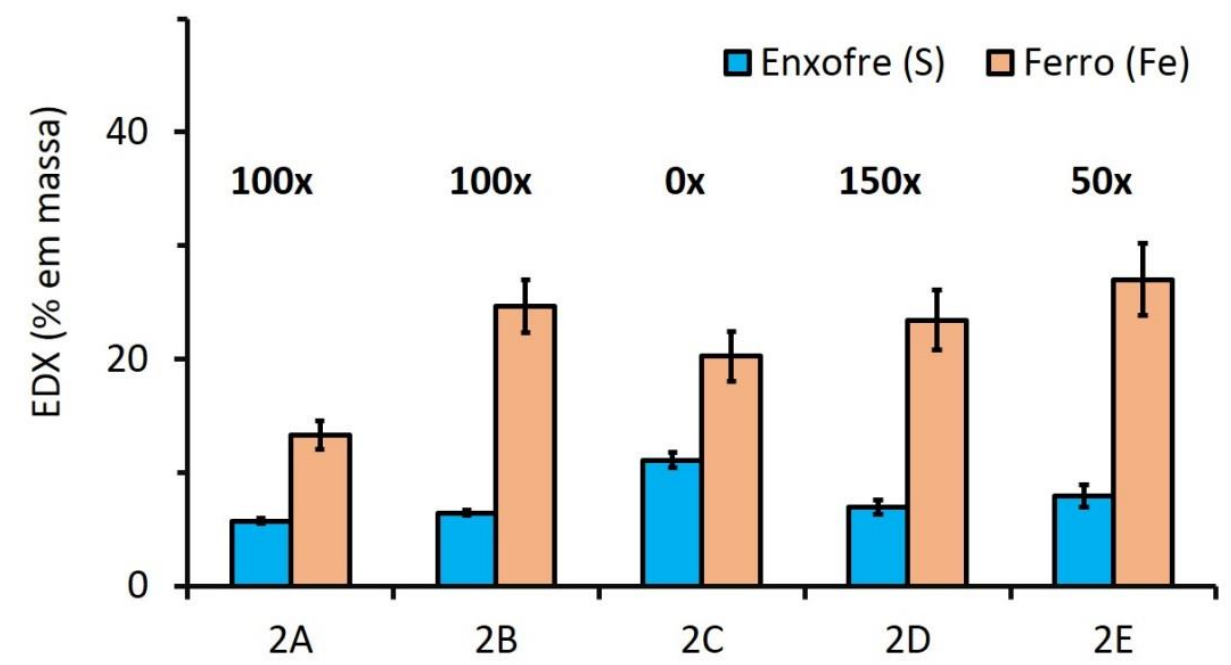

Figura 5.24. Análise do lodo aderido ao material suporte: (a) Concentrações de sólidos totais, fixos e voláteis em cada fase da ETAPA 2; e (b) Caracterização elementar por EDX das cinzas do material coletado. As barras de erro representam o desvio-padrão.

Fonte: $\mathrm{O}$ autor.

Até aqui pode-se concluir que, apesar do aumento na velocidade superficial ter implicado em menores concentrações de biomassa (medida em termos de SSV) no material suporte, em consequência do maior cisalhamento e arraste do biofilme, o desempenho do DFSBR com relação à remoção de sulfato não foi afetado. Já a remoção de DQO foi afetada pelas altas razões de recirculação, resultando em maiores concentrações de DQO solúvel residual no efluente do DFSBR durante as FASES 2A, 2B e 2D (Figura 5.22), conforme discutido anteriormente. Todavia, essa queda na eficiência de remoção de DQO pelo DFSBR 
sob altas recirculações não foi o suficiente para o colapso do sistema. Tanto a sulfetogênese quanto a metanogênese permaneceram equilibradas no reator (Figura 5.23), viabilizando o tratamento da DAM sintética com vinhaça real.

A produção de alcalinidade a bicarbonato foi adequada para a manutenção da digestão anaeróbia balanceada no sistema. Conforme mostrado pela Figura 5.25, a alcalinidade a bicarbonato diminuiu de $2230 \pm 200$ (FASE $2 \mathrm{~A})$ para $1960 \pm 150 \mathrm{mgCaCO}_{3} \cdot \mathrm{L}^{-1}(\mathrm{FASES} 2 \mathrm{~B}$ e 2C) após a introdução de ferro no sistema, o que se deveu à liberação de acidez pela formação de sulfetos metálicos (Equação (3.6)), bem como à diminuição da contribuição do sulfeto para a alcalinidade do meio líquido. Aparentemente, durante a FASE 2D, a alta razão de recirculação adotada (150 vezes) impactou na produção de alcalinidade no reator, que caiu para $1470 \pm 200 \mathrm{mgCaCO} 3 \cdot \mathrm{L}^{-1}$. Esse resultado se deu possivelmente em função do stress da biomassa pelas maiores tensões de cisalhamento aplicadas. Esse comportamento do sistema se manteve durante a última fase operacional (FASE 2E), com alcalinidade a bicarbonato de $1500 \pm 180 \mathrm{mgCaCO} \cdot \mathrm{L}^{-1}$. No entanto, a fração remanescente de alcalinidade em todas as fases da ETAPA 2 foi suficiente para a manutenção da estabilidade do processo anaeróbio. De fato, a relação Ai/Ap do reator ao longo de todo tempo de operação da ETAPA 2 foi de $0,35 \pm$ 0,10, o que confirma o equilíbrio entre a formação de ácidos orgânicos voláteis (Ai) e de alcalinidade real (Ap) no reator (RIPLEY et al., 1986). Vale notar ainda que o pH interno do reator ao longo da ETAPA 2 foi, em média, 7,2 $\pm 0,1$, enquanto que o efluente tratado do DFSBR apresentou valor médio de pH igual a 7,9 \pm 0,3 durante todo o tempo de operação.

Assim, o material suporte utilizado e a configuração do leito empregada se mostraram estratégias adequadas para o estabelecimento associado de comunidades metanogênicas e redutoras de sulfato, concorrendo para o sucesso do processo de tratamento nas diferentes condições de reciclo testadas. 


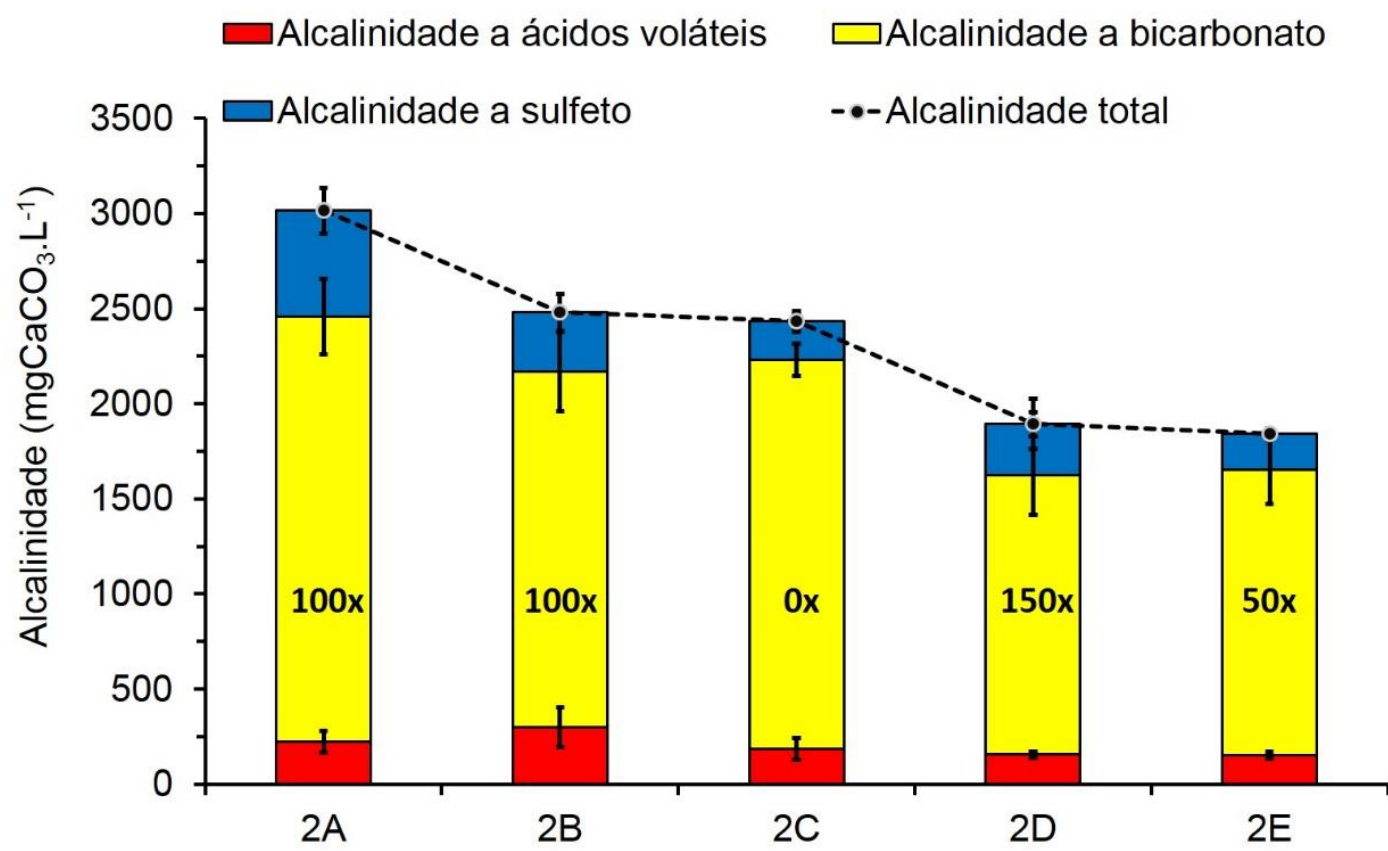

Figura 5.25. Características do efluente do DFSBR com relação às frações de alcalinidade total devidas a sulfeto, a bicarbonato e a ácidos voláteis durante a ETAPA 2. As barras de erros representam o desvio-padrão.

Fonte: $\mathrm{O}$ autor.

\subsubsection{Balanços de matéria orgânica e enxofre}

Durante a ETAPA 2 o balanço de matéria orgânica removida foi capaz de mostrar que praticamente $100 \%$ de toda DQO foi convertida a metano, sulfeto e SSV (Figura 5.23), de forma que nenhuma parcela permaneceu sem explicação, como foi o caso da ETAPA 1 (Figura 5.3). Entre as hipóteses anteriormente levantadas, além do metano dissolvido e da alta assimilação de DQO para crescimento celular, constava também a presença de oxigênio dissolvido, proveniente da água de abastecimento, com a qual o meio sintético foi preparado, ou que penetrava no DFSBR por falhas na vedação das conexões e mangueiras. Durante a ETAPA 2, por sua vez, outras estratégias foram adotadas para minimizar o aporte de oxigênio atmosférico para o sistema, como troca de conexões, mangueiras e bomba de reciclo. Além 
disso, a utilização da vinhaça real também pode ter contribuído para a minimização do oxigênio dissolvido proveniente do meio sintético, o qual era preparado utilizando água de abastecimento. Dessa forma, tanto o balanço de matéria orgânica, quanto do enxofre (Figura 5.26) apresentaram melhores resultados na ETAPA 2.

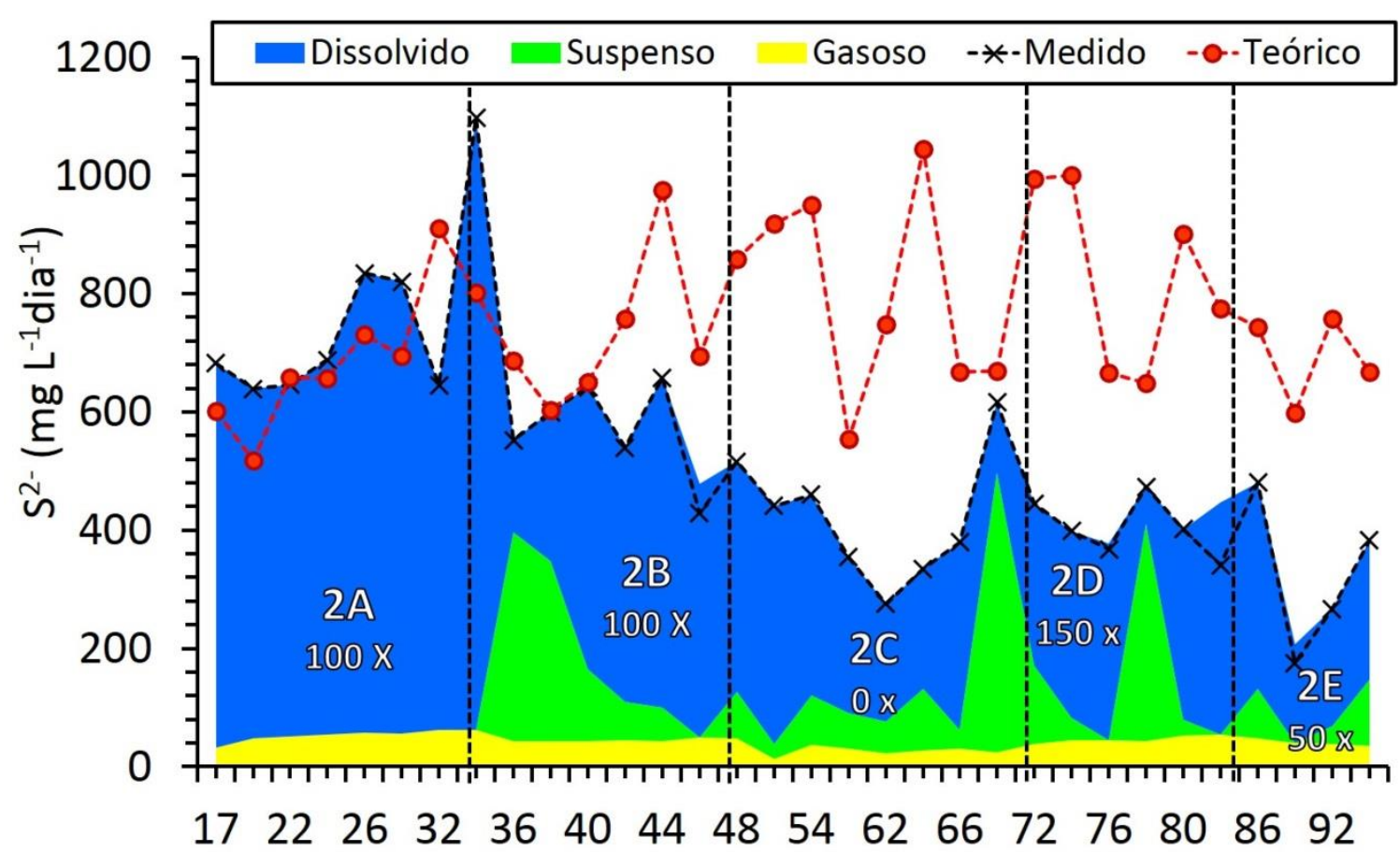

Figura 5.26: Frações de sulfeto produzidas pelo reator DFSBR ao longo da ETAPA 2.

Fonte: $\mathrm{O}$ autor.

Durante a FASE 2A, operada sem adição da solução concentrada de cloreto ferroso, os valores de sulfeto determinados foram próximos do sulfeto teórico calculado a partir do sulfato removido ( $0,333 \mathrm{mg}$ de sulfeto por $\mathrm{mg}$ de sulfato reduzido), o que indicou o sucesso das estratégias de minimização do aporte de $\mathrm{O}_{2}$ no DFSBR. Assim, a reoxidação parcial do sulfeto a outros compostos intermediários de enxofre foi reduzida.

Ao longo das FASES 2B a 2E, operadas com carga aplicada de ferro de 0,5 a $0,7 \mathrm{gFe}^{2+} \cdot \mathrm{L}^{-1} \cdot \mathrm{d}^{-1}$, a indução da precipitação de sulfetos de ferro resultou em menores 
recuperações de sulfeto no efluente, o que indica que os sulfetos metálicos produzidos foram retidos no interior do reator. No início da FASE $2 \mathrm{~B}$ altas concentrações de sulfeto em suspensão foram identificadas, sugerindo a necessidade de efetuar o aumento na frequência dos descartes da zona de sedimentação. Isso passou a ser realizado através do descarte de $150 \mathrm{~mL}$ de líquido de fundo a cada 3 dias de operação, minimizando-se assim o escape do material precipitado (Figura 5.26). Durante a FASE 2C, operada sem recirculação, uma descarga pontual de sulfetos em suspensão também foi observada ao final da fase, indicando a ocorrência de possível saturação da zona de sedimentação. Um comportamento semelhante também foi notado durante a FASE 2D.

O gráfico da Figura 5.27 apresenta a especiação do sulfeto dissolvido durante as fases operacionais testadas na ETAPA 2.

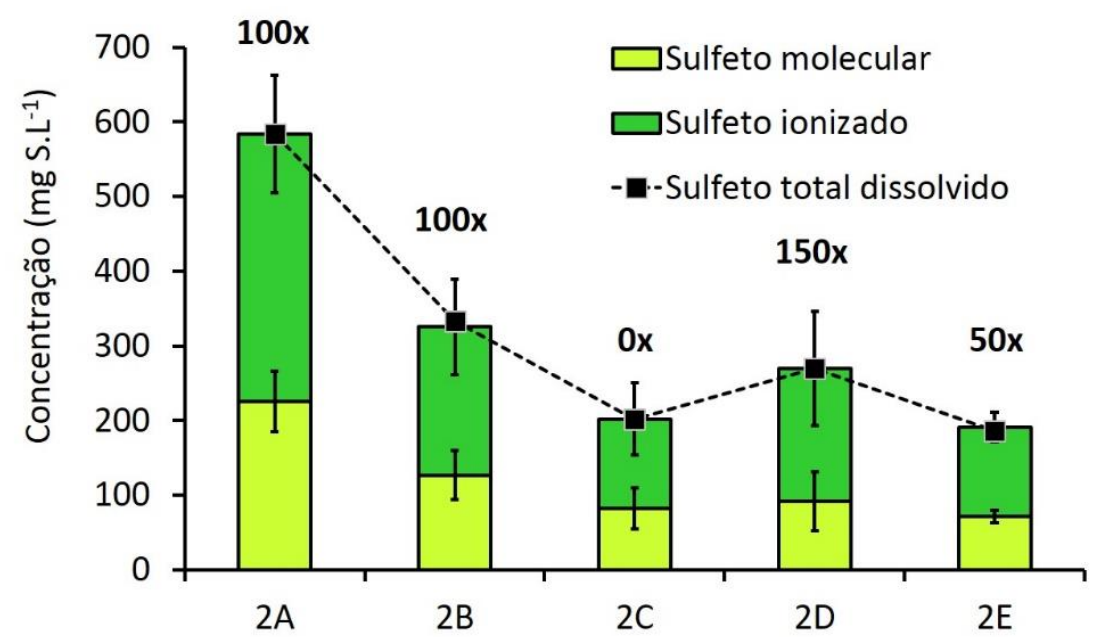

Figura 5.27. Concentrações de sulfeto total dissolvido, sulfeto de hidrogênio molecular $\left(\mathrm{H}_{2} \mathrm{~S}\right)$ e sulfeto ionizado $\left(\mathrm{HS}^{-}\right)$no efluente do reator DFSBR durante a ETAPA 2. As barras de erros representam o desvio-padrão.

Fonte: $\mathrm{O}$ autor.

Durante a FASE 2A, sem adição de ferro, as concentrações médias de sulfeto total dissolvido (STD) e de sulfeto de hidrogênio molecular $\left(\mathrm{H}_{2} \mathrm{~S}\right)$ foram de $590 \pm 110 \mathrm{mg} . \mathrm{L}^{-1} \mathrm{e}$ $225 \pm 40 \mathrm{mg} \cdot \mathrm{L}^{-1}$, respectivamente. Essas concentrações foram maiores que as concentrações 
médias obtidas durante a FASE 1A (cerca de 350 e 140 mg.L $\mathrm{L}^{-1}$, respectivamente). Apesar das concentrações de STD e de sulfeto molecular estarem acima dos limites recomendados pela literatura (MAILLACHERUVU et al., 1993), não foi identificada inibição ou desequilíbrio da digestão anaeróbia durante essa fase, não tendo sido observados acúmulos de ácido acético ou propiônico no efluente (Figura 5.22), como seria usual nesses casos (GODOI et al., 2015; MCCARTNEY; OLESZKIEWICZ, 1991). Tampouco a atividade metanogênica foi prejudicada. Pelo contrário, como acima mencionado, a metanogênese foi predominante durante a FASE 2A (Figura 5.23).

Uma possível explicação para a expressiva participação da metanogênese no processamento da vinhaça durante a FASE 2A, apesar do maior potencial de toxicidade pelo sulfeto desta fase, também pode estar relacionada com o arranjo espacial do biofilme. Uma vez que os microrganismos metanogênicos geralmente se localizam nas zonas mais profundas do biofilme, como já mencionado anteriormente, são favorecidos tanto pela proximidade com as bactérias fermentativas (SPEECE, 1996), quanto protegidos da toxicidade pelo sulfeto devido à limitação à transferência de massa dos íons sulfeto e sulfato (NIELSEN, 1987; OVERMEIRE et al., 1994). É possível ainda que esse comportamento seja mais acentuado com relação à biomassa imobilizada no interior dos módulos de polietileno.

Durante as FASES 2B a 2E, por sua vez, as concentrações residuais de STD no efluente diminuíram devido à precipitação com o ferro introduzido (Figura 5.27). As menores concentrações de STD observadas foram alcançadas durante as fases operadas com as menores razões de reciclo (FASES 2C - sem reciclo; e FASE 2E - 50 vezes). Esse resultado também esteve associado à menor recuperação do enxofre teórico introduzido no sistema durante essas fases (Figura 5.26). Tal observação indicou claramente a retenção efetiva do sulfeto precipitado sob as condições testadas com menores razões de reciclo e, consequentemente, com as menores velocidades superficiais do escoamento. 
Seria esperado que durante as fases operadas com as maiores vazões de reciclo uma parcela considerável do sulfeto fosse mais facilmente transferida para a fase gasosa, resultando em menores concentrações desse composto na fase líquida (GIL-GARCIA et al., 2017). Todavia, os ensaios hidrodinâmicos, anteriormente apresentados (subseção 5.3.1, p. 147), permitiram afirmar que não ocorreram mudanças relevantes no padrão de mistura e no grau de turbulência do reator devido às razões de recirculação aplicadas. Nesse caso, a produção de biogás, graças à manutenção de uma população metanogênica ativa, foi o fator preponderante no arraste do sulfeto dissolvido para o headspace, não tendo sido observado aumento da sua proporção no biogás devido às maiores velocidades superficiais do líquido. De fato, em todas as fases operacionais da ETAPA 3, a composição do biogás produzido foi de $57 \pm 7 \%$ de $\mathrm{CH}_{4}, 28 \pm 4 \%$ de $\mathrm{CO}_{2}$ e $5 \pm 1 \%$ de $\mathrm{H}_{2} \mathrm{~S}$. Os dados referentes ao metano produzido durante a ETAPA 2 estão resumidos na Figura 5.28.

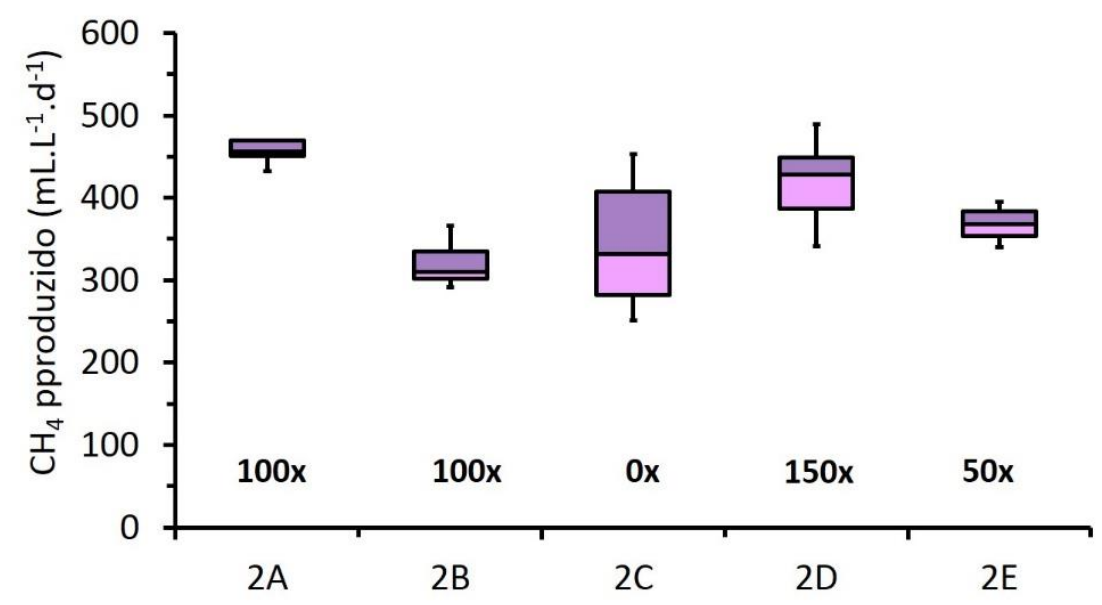

Figura 5.28: Análise estatística de Boxplot da produção volumétrica de metano da ETAPA 2. Dados corrigidos para as CNTP $\left(0^{\circ} \mathrm{C}\right.$ e $\left.1 \mathrm{~atm}\right)$.

Fonte: $\mathrm{O}$ autor.

Durante a FASE 2A, sem adição de ferro, o DFSBR apresentou produção volumétrica de metano da ordem de $480 \mathrm{~mL} . \mathrm{L}^{-1}$ reator.d $\mathrm{d}^{-1}$ (valores nas CNTP). Logo após a introdução de 
ferro essa produção caiu para a faixa de 320 a $400 \mathrm{~mL} \cdot \mathrm{L}^{-1}$ reator.d $\mathrm{d}^{-1}$ durante as FASES 2B a 2E, respectivamente. Esse comportamento esteve ligado com a menor participação da metanogênese no processo global de remoção da matéria orgânica (Figura 5.23). A manutenção da produção de metano em todas as fases operacionais da presente ETAPA, por sua vez, sugere a viabilidade da recuperação de energia pelo reaproveitamento do biogás em sistemas de tratamento de DAM, utilizando águas residuárias orgânicas como doadores de elétrons.

\subsubsection{Precipitação de sulfetos de ferro em diferentes razões de reciclo}

A Figura 5.29 apresenta os resultados do desempenho do DFSBR com relação à remoção de ferro nas diferentes razões de reciclo estudadas. 
(a)

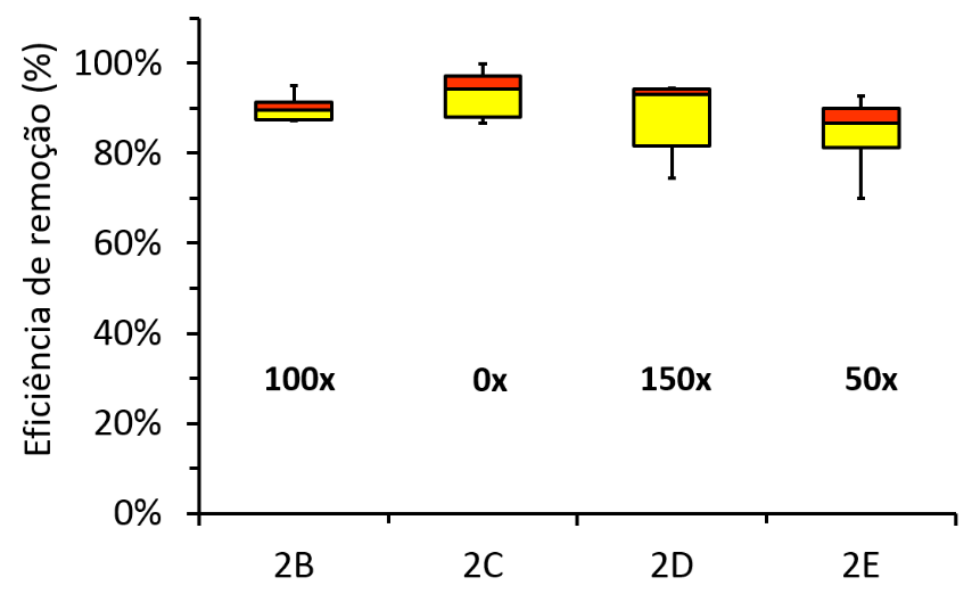

(b)

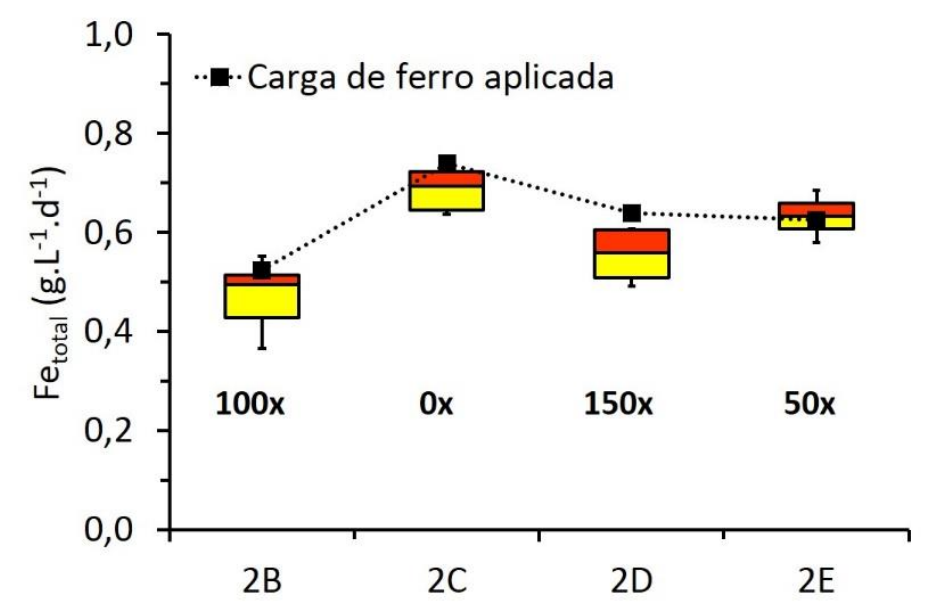

Figura 5.29. Desempenho do DFSBR na remoção de ferro: (a) Análise estatística de Boxplot das eficiências de remoção de ferro obtidas nas FASES 2B a 2E; e (b) Análise estatística de Boxplot das cargas de ferro removidas e cargas de ferro médias aplicadas durante a ETAPA 2.

Fonte: $\mathrm{O}$ autor.

Durante a FASE 2B o reator foi operado com vazão de reciclo da ordem de 100 vezes a vazão afluente $\left(V_{S}=3,50 \mathrm{~m} \cdot \mathrm{h}^{-1}\right)$ e recebendo carga de ferro aplicada próxima de $0,55 \mathrm{gFe}^{2+} \cdot \mathrm{L}^{-1} \cdot \mathrm{d}^{-1}$. As eficiências de remoção de ferro nessa fase foram de $88 \pm 4 \%$. Após o desligamento da recirculação (FASE $2 \mathrm{C} ; \mathrm{V}_{\mathrm{S}}=0,03 \mathrm{~m} \cdot \mathrm{h}^{-1}$ ) e sob carga aplicada próxima de $0,75 \mathrm{gFe}^{2+} \cdot \mathrm{L}^{-1} \cdot \mathrm{d}^{-1}$ (maior que na fase anterior), o reator apresentou $96 \pm 3 \%$ de eficiência de remoção de ferro. Durante as FASES 2D e 2E, operadas com razões de reciclo de 150 e 50 
vezes, respectivamente, as eficiências foram próximas a 91\% de remoção de ferro (cargas aplicadas da ordem de $\left.0,65 \mathrm{gFe}{ }^{2+} \cdot \mathrm{L}^{-1} \cdot \mathrm{d}^{-1}\right)$, conforme mostrado na Tabela 5.10.

Tabela 5.10. Cargas volumétricas de ferro aplicadas (CFVa) e removidas (CFVr), e eficiências de remoção de ferro total (ER-Fe) durante a ETAPA 2.

\begin{tabular}{cccc}
\hline FASES & $\begin{array}{c}\text { CFVa } \\
\left(\mathbf{g F e}^{\mathbf{2 +}} \cdot \mathbf{L}^{-\mathbf{1}} \cdot \mathbf{d}^{-\mathbf{1}}\right)\end{array}$ & $\begin{array}{c}\text { ER-Fe } \\
(\boldsymbol{\%})\end{array}$ \\
\hline $\mathbf{2 A} *$ & $<0,002$ & & \\
$\mathbf{2 B}$ & $0,54 \pm 0,12$ & $0,49 \pm 0,10$ & $88 \pm 4$ \\
$\mathbf{2 C}$ & $0,74 \pm 0,12$ & $0,71 \pm 0,04$ & $96 \pm 3$ \\
2D & $0,64 \pm 0,05$ & $0,55 \pm 0,06$ & $91 \pm 6$ \\
2E & $0,66 \pm 0,10$ & $0,63 \pm 0,06$ & $90 \pm 4$ \\
\hline
\end{tabular}

*Durante a FASE 2A não foi realizado o monitoramento da remoção de ferro, visto que esse metal foi adicionado em concentrações traço, exclusivamente como nutriente para a biomassa.

Fonte: $\mathrm{O}$ autor.

Diferenças estatisticamente significativas entre os dados de eficiência de remoção de ferro $(\mathrm{p}<0,05)$ foram identificadas entre a FASE 2C (sem reciclo) e as FASES 2B e 2D (com maiores razões de reciclo).

Os dados indicaram que a ausência de recirculação promoveu as melhores condições de precipitação e remoção de ferro no DFSBR, o que foi atribuído às baixas velocidades superficiais de escoamento. Apesar do aumento da velocidade descensional favorecer o arraste dos sulfetos metálicos em reatores fluidizados de fluxo descendente (SAHINKAYA; GUNGOR, 2010; GALLEGOS-GARCIA et al., 2009), no caso da presente configuração (DFSBR) as maiores velocidades de reciclo devem ter causado a ressuspensão do material sedimentado. Esse comportamento pode estar relacionado com a localização da linha de reciclo. A sucção do líquido próximo à base do reator deve ter implicado na formação de turbulência excessiva nessa região durante as fases operacionais com maiores razões de 
reciclo, o que promoveu o escape dos sulfetos precipitados pela linha do efluente. A análise visual do Boxplot (Figura 5.29.a) indicou maior dispersão dos resultados durante a FASE 2D (reciclo de 150 vezes) sugerindo a limitação do reator em manter eficiências de remoção de ferro relativamente constantes durante essa condição operacional.

Assim, durante a FASE 2C não ocorreram perdas de eficiência de remoção de matéria orgânica e sulfato (Figura 5.21) e as concentrações de sulfeto dissolvido remanescente no efluente foram menores (Figura 5.27). Uma vez que também foi observada maior retenção dos sulfetos em suspensão no interior do reator (Figura 5.26), abriram-se novas perspectivas para a aplicação do DFSBR na ausência de recirculação da fase líquida. De fato, a operação do reator sem recirculação promove maiores vantagens econômicas ao processo de tratamento, por diminuir o requerimento de energia, a qual é demandada pela manutenção da linha de recirculação com alta vazão (RAJESHWARI et al., 2000).

Partindo dos resultados fornecidos pela ETAPA 2, o DFSBR foi mantido sem recirculação da fase líquida durante toda a ETAPA 3. Nessa etapa, cujos resultados serão amplamente apresentados na próxima seção (5.4, p. 193), o reator operou com cargas de ferro aplicadas de $0,30 \pm 0,05 \mathrm{~g} \cdot \mathrm{L}^{-1} \cdot \mathrm{d}^{-1}$. Os dados referentes às cargas de ferro removidas durantes as três etapas de operação do DFSBR sob diferentes condições de recirculação da fase líquida foram utilizados em conjunto para a análise de correlação apresentada no gráfico da Figura 5.30 . 


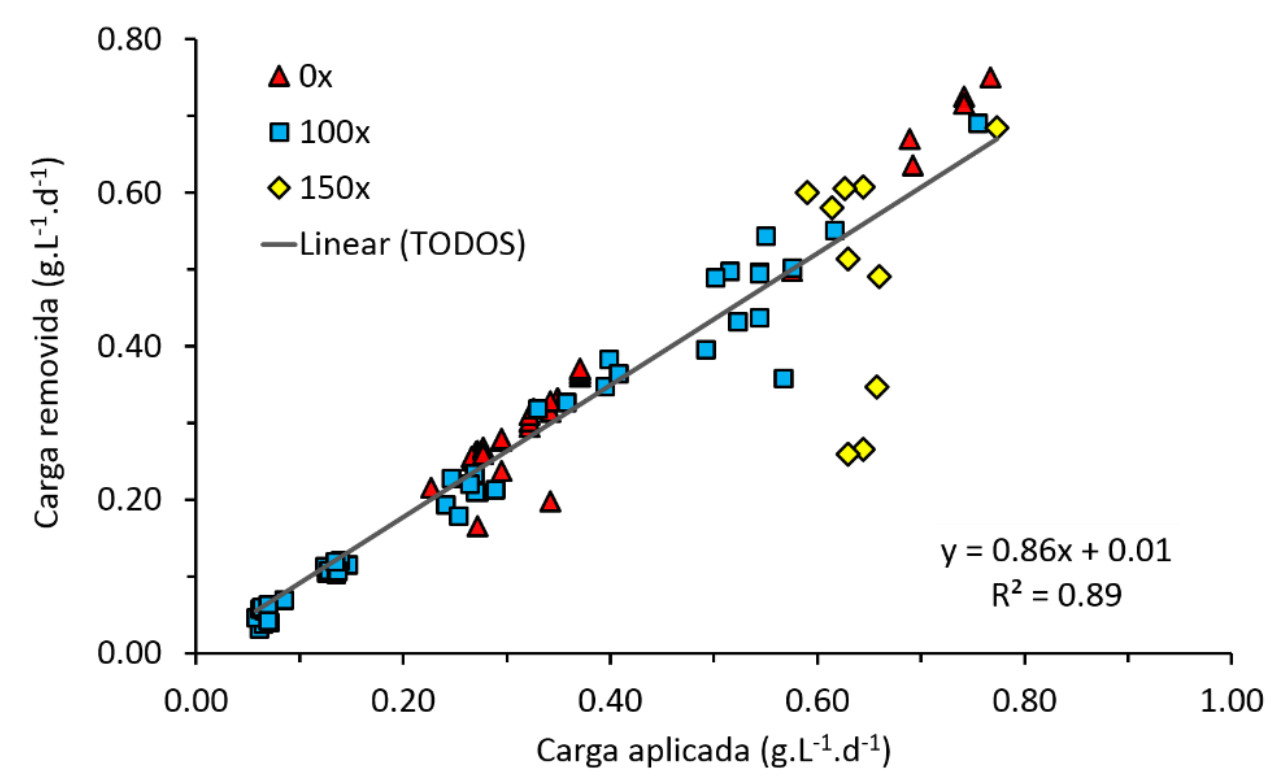

Figura 5.30. Correlação entre as cargas volumétricas de ferro aplicadas e removidas no DFSBR sob diferentes razões de recirculação ao longo das três ETAPAS de operação.

Fonte: $\mathrm{O}$ autor.

A observação da correlação estabelecida permite inferir que razões de reciclo da ordem de 150 vezes a vazão afluente não foram efetivas para a sedimentação dos sulfetos metálicos. Durantes as fases operadas com reciclo de 100 vezes o DFSBR apresentou cargas removidas de ferro crescentes, acompanhando as cargas aplicadas, com aumento da dispersão dos dados quando o DFSBR operou com cargas de ferro aplicadas da ordem de $0,60 \mathrm{~g} \cdot \mathrm{L}^{-1} \cdot \mathrm{d}^{-1}$. Por outro lado, durante as fases operadas sem reciclo o reator foi capaz de suportar o aumento nas cargas aplicadas de ferro, sem perda da capacidade de precipitar e reter o metal introduzido, mesmo sob as maiores cargas de ferro aplicada testadas.

Durante a ETAPA 2 foram descartados $150 \mathrm{~mL}$ do material sedimentado no fundo do reator a cada 3 dias de operação. Amostras desse material foram submetidas à análise gravimétrica para determinação da concentração de sólidos totais, fixo e voláteis. O resíduo da calcinação (sólidos fixos) foi caracterizado via EDX para determinação da composição do precipitado. Os resultados das análises são mostrados na Figura 5.31. 
(a)

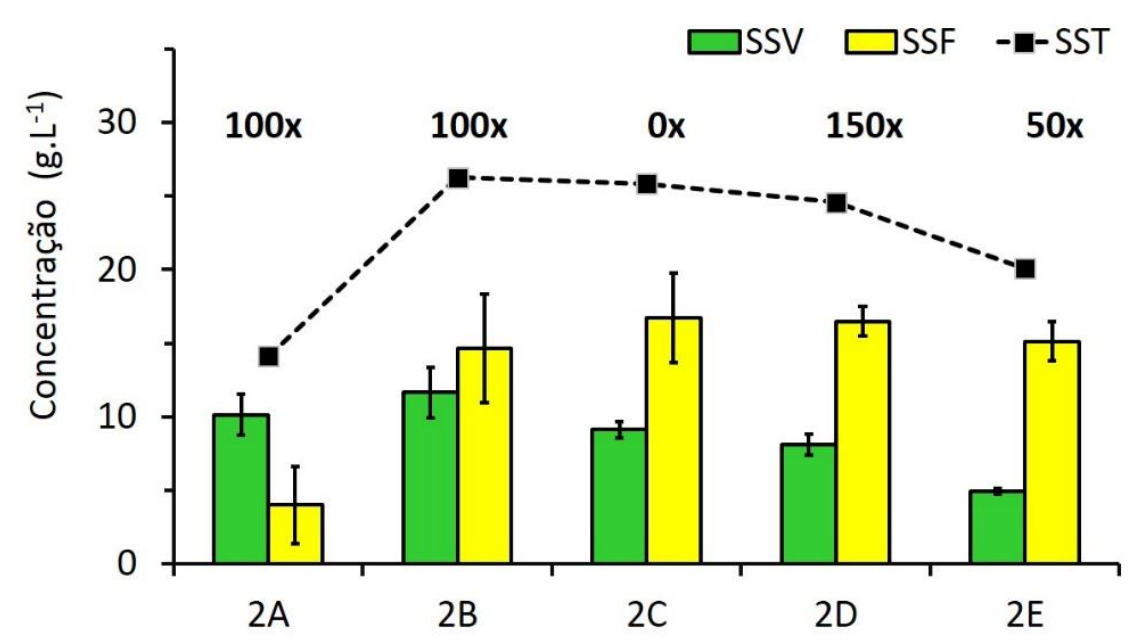

(b)

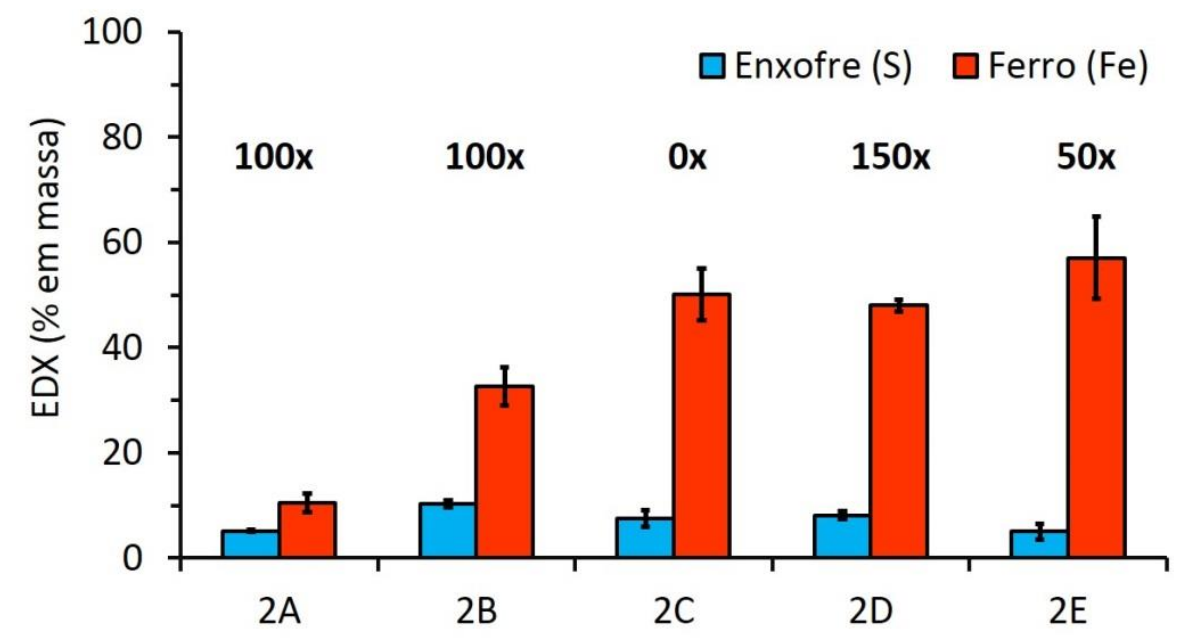

Figura 5.31. Análise do material precipitado: (a) Concentrações de sólidos totais, fixos e voláteis nas amostras de descarte em cada fase da ETAPA 2; e (b) Caracterização elementar por EDX das cinzas do material coletado. As barras de erro representam o desvio-padrão.

Fonte: $\mathrm{O}$ autor.

A concentração de sólidos fixos no material sedimentado foi da ordem de 4 g.L $\mathrm{L}^{-1}$ durante a FASE 2A, operada sem dosagem da DAM sintética, e de $14 \pm 2$ g. $\mathrm{L}^{-1}$ nas fases operadas com carga aplicada de ferro entre 0,5 e 0,7 g.L. . $^{-1} \mathrm{~d}^{-1}$ (Figura 5.31.a). Nas cinzas do lodo sedimentado foram identificadas proporções de ferro da ordem de $10 \%$ durante a FASE 2A, de 35\% durante a FASE 2B (100x), de 50\% durante a FASES 2C (0x), de 48\% durante a FASE 2D (150x) e de 57\% durante a FASE 2E (50x) (Figura 5.31.b). 
Assim, as maiores proporções de ferro precipitado foram obtidas durante as FASES 2E e 2C, operadas, respectivamente, com a menor taxa de reciclo e na ausência de recirculação. Esses resultados confirmaram a efetiva retenção dos sulfetos de ferro no DFSBR operado com baixas velocidades superficiais de escoamento.

\subsubsection{Perfis espaciais do DFSBR sob diferentes razões de reciclo}

Ao final das FASES 2B a 2E foram realizados perfis das concentrações de DQO, sulfato, sulfeto total e ferro total ao longo do leito do reator DFSBR e das zonas de sedimentação e equalização de nível. A localização de cada ponto de coleta de amostra pode ser visualizada na Figura 4.4, já mostrada anteriormente.

O perfil longitudinal de concentrações de matéria orgânica e sulfato, mostrados na Figura 5.32, corroboraram a caracterização hidrodinâmica do DFSBR como reator de mistura, de forma que nas quatro FASES analisadas, as concentrações de DQO e sulfato ao longo do reator se apresentaram próximas das concentrações medidas no efluente. 


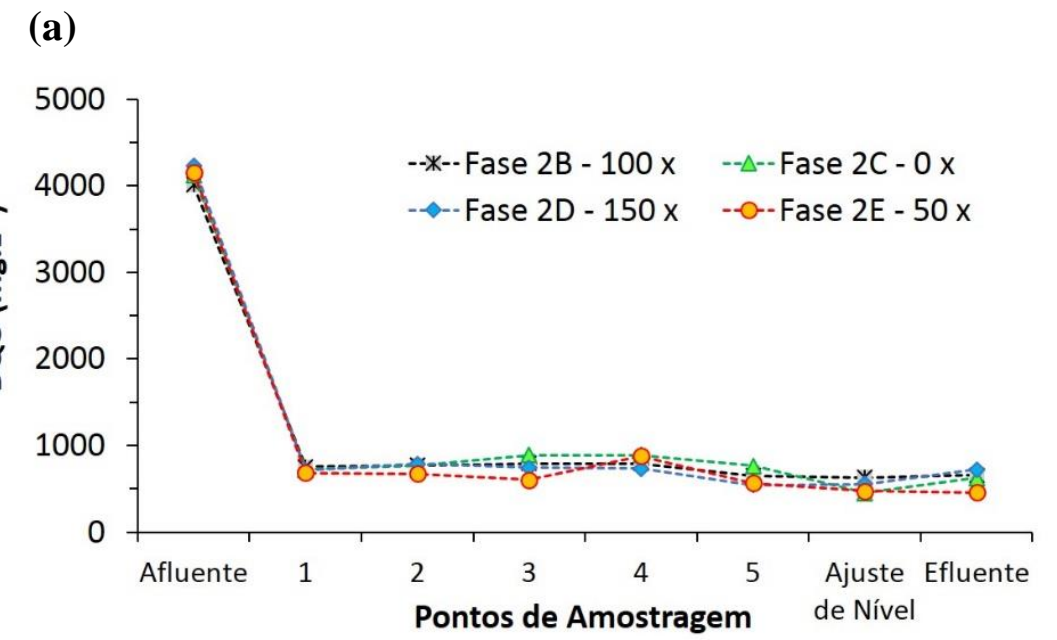

(b)

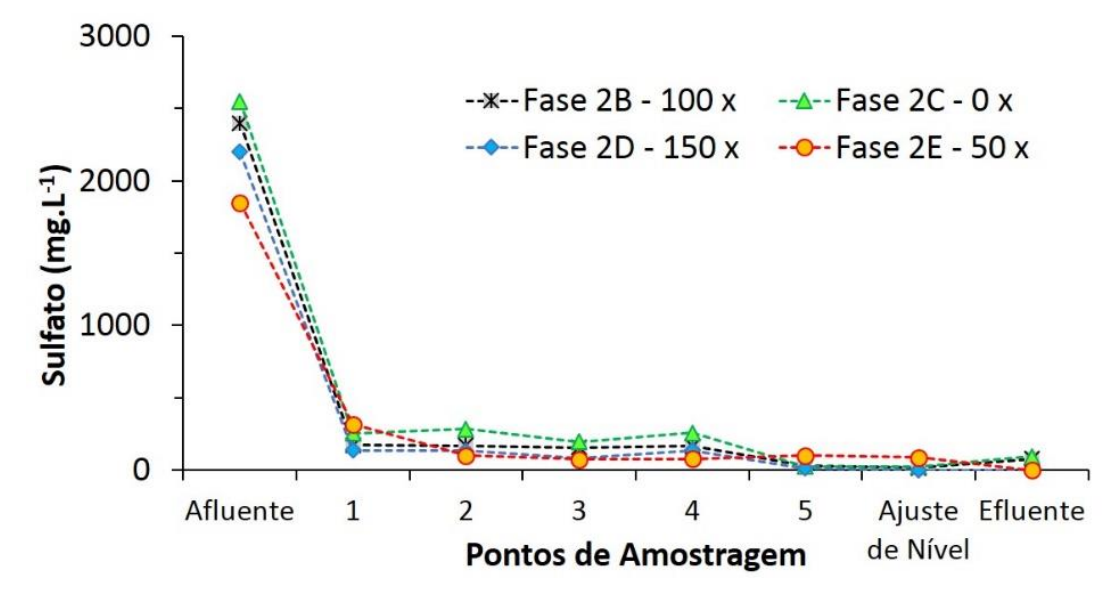

Figura 5.32. Perfis longitudinais de concentração de DQO (a) e sulfato (b) no DFSBR ao final das FASES 2B a 2C.

Fonte: $\mathrm{O}$ autor.

Os perfis de concentração de sulfeto total e ferro total ao longo do DFSBR, mostrados na Figura 5.33, indicaram que, durante a FASE operada sem reciclo (2C), o acúmulo de sulfeto e ferro se deu predominantemente na zona de equalização de nível do reator (Ponto de amostragem nº6). Já com a aplicação da recirculação da fase líquida, expressivas parcelas de ferro e sulfeto também foram encontradas na zona de sedimentação (Ponto nº5), logo acima do cone de descarte do DFBSR (Figura 5.33). Essa observação pode ser atribuída à ocorrência de ressuspensão do material sedimentado pelas maiores velocidades superficiais de escoamento, como já mencionado anteriormente. 

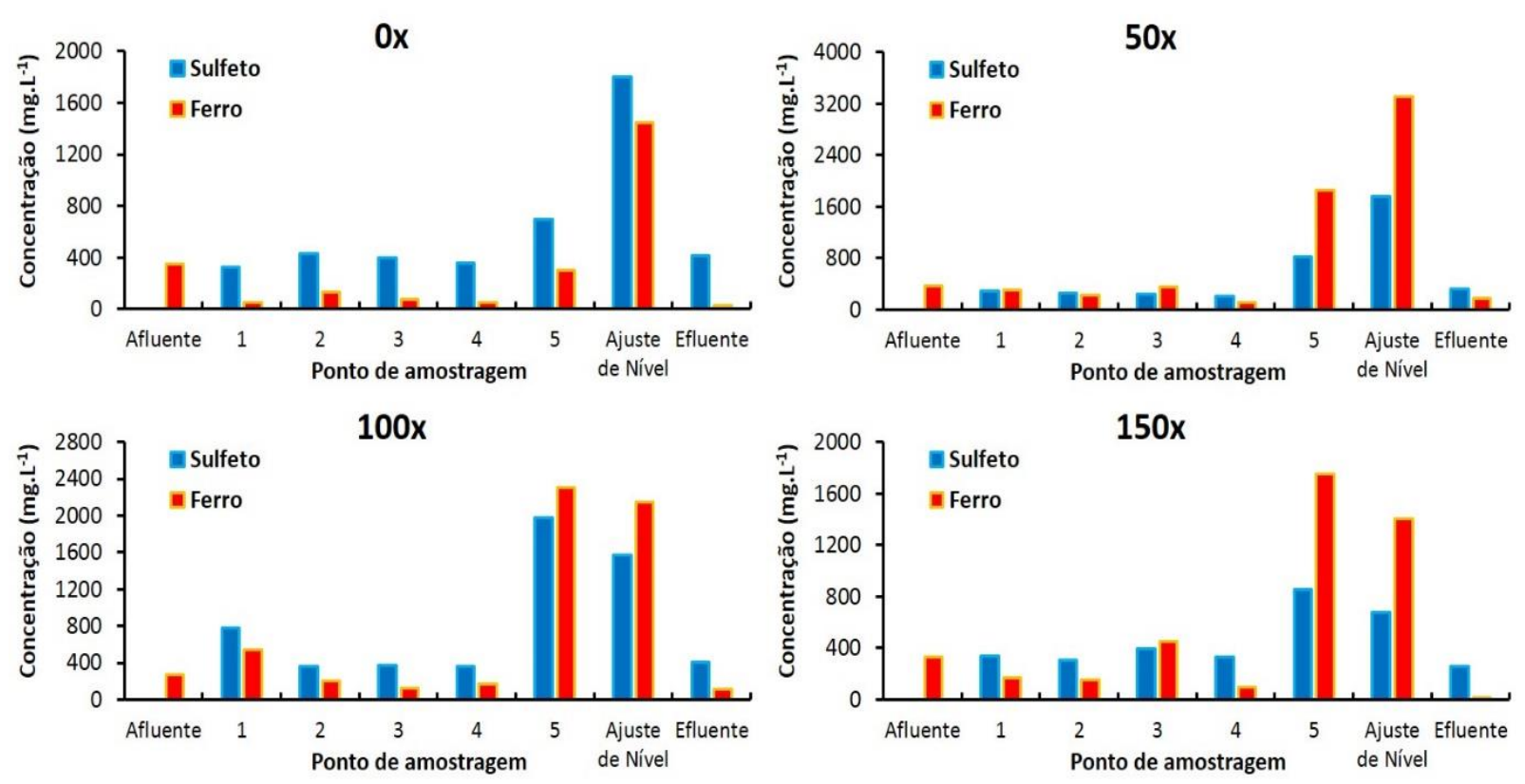

Figura 5.33. Perfis longitudinais de concentração de sulfeto total e ferro total no DFSBR ao final das FASES 2B (100 x), 2C (0 x), 2D (150 x) e 2E (50 x).

Fonte: $\mathrm{O}$ autor.

De qualquer forma, a configuração do DFSBR se mostrou adequada para a precipitação de sulfetos metálicos, proporcionando o estabelecimento de duas regiões distintas que viabilizaram a coleta do material precipitado para recuperação dos metais de interesse.

Por fim, vale ressaltar que os resultados das análises de EDX, por sua natureza qualitativa, não puderam ser utilizados para fins de balanços de massa para verificação da recuperação do ferro removido no sistema.

\subsubsection{Caracterização da diversidade microbiana-ETAPA 2}

Para caracterização da diversidade microbiana cultivada no DFSBR ao longo da ETAPA 2 foram efetuadas análises de DGGE em amostras dos inóculos utilizados (IN-1 e IN2) e em amostras de biomassa retirada do material suporte ao final das FASES 2A, 2B e 2E. 
As amostras de biomassa do reator foram escolhidas para representar a diversidade obtida no sistema alimentado com vinhaça real antes (FASE 2A) e imediatamente após (FASE 2B) a introdução da DAM sintética rica em ferro, assim como para avaliar a diversidade microbiana ao final da operação do DFSBR (FASE 2E), após 100 dias de ensaio.

Os dendrogramas, construídos a partir dos padrões de bandas do DGGE realizado com set primers para os Domínios Archaea e Bacteria, são mostrados na Figura 5.34.

Os padrões das bandas de DGGE para o Domínio Archaea (Figura 5.34.a) mostraram a predominância visualmente notável de uma banda específica em todas as amostras. Baixa similaridade $(65 \%)$ foi observada entre a amostra obtida ao final da FASE 2A e todas as outras amostras. Esse resultado permite supor que ao longo das FASES 2B a 2E a adaptação da biomassa e as condições ambientais do reator promoveram o enriquecimento de algumas populações de arqueias presentes originalmente nos inóculos, mas que durante a FASE 2A haviam sido restringidas, possivelmente pelas altas concentrações de sulfeto total dissolvido (Figura 5.27). Nas fases subsequentes, por sua vez, a precipitação do sulfeto induzida pela adição da DAM sintética pode ter favorecido a retomada do crescimento desses grupos anteriormente inibidos.

Maiores coeficientes de similaridade $(86 \%)$ foram encontrados entre a amostra do inóculo IN-2 e as amostras referentes às FASES 2B e 2E, em comparação com o inóculo IN-1 (77\%). Esse fator já era esperado pela adaptação prévia das AM presentes no IN-2 ao substrato utilizado. De fato, o lodo anaeróbio IN-2 foi proveniente de um reator UASB em escala piloto tratando a mesma vinhaça de cana-de-açúcar utilizada no presente estudo (ALVES, 2018 - trabalho de doutorado em andamento) ${ }^{2}$. Assim, a comunidade de AM proporcionadas pelo IN-2 foram favorecidas pela similaridade com o substrato disponível.

${ }^{2}$ ALVES, I. Estudo da manta de lodo e do efeito das taxas de recirculação e das cargas orgânicas em reatores UASB para produção de metano no processamento da vinhaça de cana-de-açúcar. Tese (Doutorado). Trabalho em andamento pelo Programa de Pós Graduação em Engenharia Hidráulica e Saneamento da Escola de Engenharia de São Carlos (EESC/USP). 
(a) Domínio Archaea
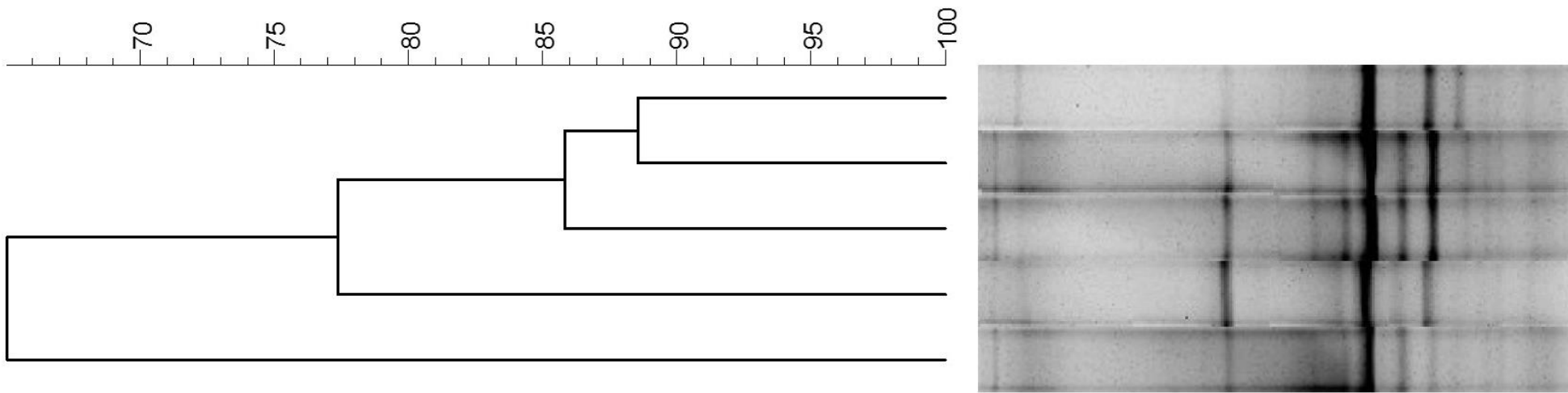

IN-2

FASE 2B

FASE 2E

IN-1

FASE 2A

(b) Domínio Bacteria

\begin{tabular}{|c|c|c|}
\hline 吊 & & \\
\hline
\end{tabular}
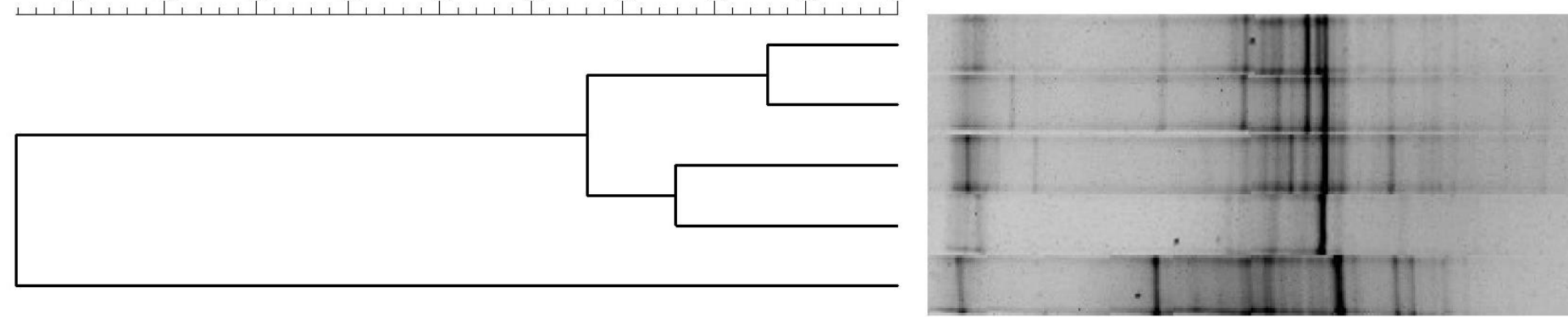

FASE 2E

FASE 2B

FASE 2A

IN-2

IN-1

Figura 5.34: Dendrogramas baseados no coeficiente de similaridade de Pearson a partir do padrão de bandas do DGGE encontrado nos inóculos (IN-1 e IN-2) e em amostras de biomassa coletadas ao final das FASES 2A, 2B e 2E para os Domínios Archaea (a) e Bacteria (b).

Fonte: $\mathrm{O}$ autor. 
Com relação à diversidade encontrada para o Domínio Bacteria, baixa similaridade (52\%) foi observada entre a amostra do inóculo IN-1 e todas as outras amostras. Esse resultado indicou que as populações de bactérias estabelecidas no DFSBR alimentado com vinhaça real foram, predominantemente, oriundas do inóculo IN-2, devido ao alto grau de adaptação dos consórcios microbianos ao substrato utilizado, da mesma forma que para o Domínio Archaea. Assim, as bactérias dedicadas ao processamento de compostos orgânicos relacionados à degradação de proteínas e lipídios, caso do inóculo IN-1 (lodo de UASB tratando efluente de avícola), devem ter sido facilmente suplantadas por comunidades especializadas em fermentar os carboidratos residuais, ácidos orgânicos e álcoois presentes na vinhaça.

Maior similaridade (88\%) entre o inóculo IN-2 e a biomassa obtida ao final da FASE 2A em relação às amostras das fases subsequentes (82\%), por sua vez, pode estar ligada às mudanças graduais sofridas pela biomassa oriunda do inóculo, com o enriquecimento de outros grupos de bactérias favorecidos pelas condições sulfato-redutoras ao longo da ETAPA 2. Essa hipótese pode ser inferida também pela observação do aparecimento de bandas do DGGE das amostras das FASES 2A a 2E visualmente ausentes nos padrões de bandas dos inóculos (Figura 5.34.b).

Já as amostras de biomassa obtidas ao final das FASES 2B e 2E foram altamente similares entre si (93\%), indicando baixa modificação no biofilme entre essas fases operacionais. Assim, as condições testadas ao longo da ETAPA 2 (variações na razão de reciclo e nas velocidades superficiais do escoamento) não impactaram expressivamente a composição da biomassa do DFSBR.

A utilização de dois lodos anaeróbios para inoculação simultânea do DFSBR durante a partida da ETAPA 2 foi realizada com o intuito de favorecer uma maior diversidade de grupos de microrganismos para o sucesso do tratamento da DAM sintética em co-digestão com 
vinhaça. Todavia, os resultados das análises realizadas sugerem que o lodo $\mathrm{IN}-2$ poderia ser aplicado sozinho como inóculo do sistema, visto seu alto grau de adaptação ao substrato orgânico utilizado. Ainda assim, não se pode afirmar a origem dos grupos de BRS estabelecidas no DFSBR. De qualquer forma, é de se esperar que o lodo IN-2, cultivado com a vinhaça in natura, também possa ser utilizado com sucesso para a partida da sulfetogênese. E isso principalmente pelo fato da vinhaça em questão também ser caracterizada por uma concentração de sulfato da ordem de 25 g. $\mathrm{L}^{-1}\left(\mathrm{DQO} / \mathrm{SO}_{4}{ }^{2-} \approx 5,0\right)$, provendo uma condição viável para o metabolismo de BRS no reator anaeróbio utilizado como fonte do inóculo IN-2.

\subsubsection{Ensaios cinéticos a partir de diferentes doadores de elétrons}

Ao final da ETAPA 2 o reator DFSBR voltou a ser submetido à vazão de recirculação de 100 vezes a vazão afluente para garantir condições de mistura durante os ensaios cinéticos que foram realizados em batelada (alimentação contínua desligada), conforme descrito na seção 4.9, p. 91. O reator foi drenado e preenchido rapidamente com a água residuária com concentrações iniciais de DQO e sulfato ajustadas para cerca de $1100 \mathrm{mg} . \mathrm{L}^{-1}$ e $600 \mathrm{mg} . \mathrm{L}^{-1}$, respectivamente, visando à manutenção de uma relação $\mathrm{DQO} / \mathrm{SO}_{4}{ }^{2-}$ próxima de $2,0 . \mathrm{O} \mathrm{pH}$ inicial dos ensaios foi ajustado em próximo de 7,20 por dosagem de solução $12 \mathrm{M}$ de $\mathrm{NaOH}$.

Foram testados como doadores de elétrons a vinhaça de cana-de-açúcar, o etanol e os ácidos orgânicos acético, propiônico e lático, de forma a avaliar a versatilidade da biomassa, cultivada com vinhaça real, a qual se trata de um substrato complexo, favorável para o estabelecimento de diferentes grupos microbianos, capazes de executar a degradação de vários substratos orgânicos (Objetivo específico 2: Sub-hipótese 2C).

A Figura 5.35 apresenta os perfis temporais de decaimento das concentrações de DQO e sulfato em cada ensaio cinético com os respectivos ajustes matemáticos obtidos. Uma vez que não foi possível realizar cada ensaio em replicatas, um desvio-padrão de $10 \%$ foi 
estimado com base no erro que foi observado durante as análises das amostras de monitoramento de rotina do reator (dados não mostrados).
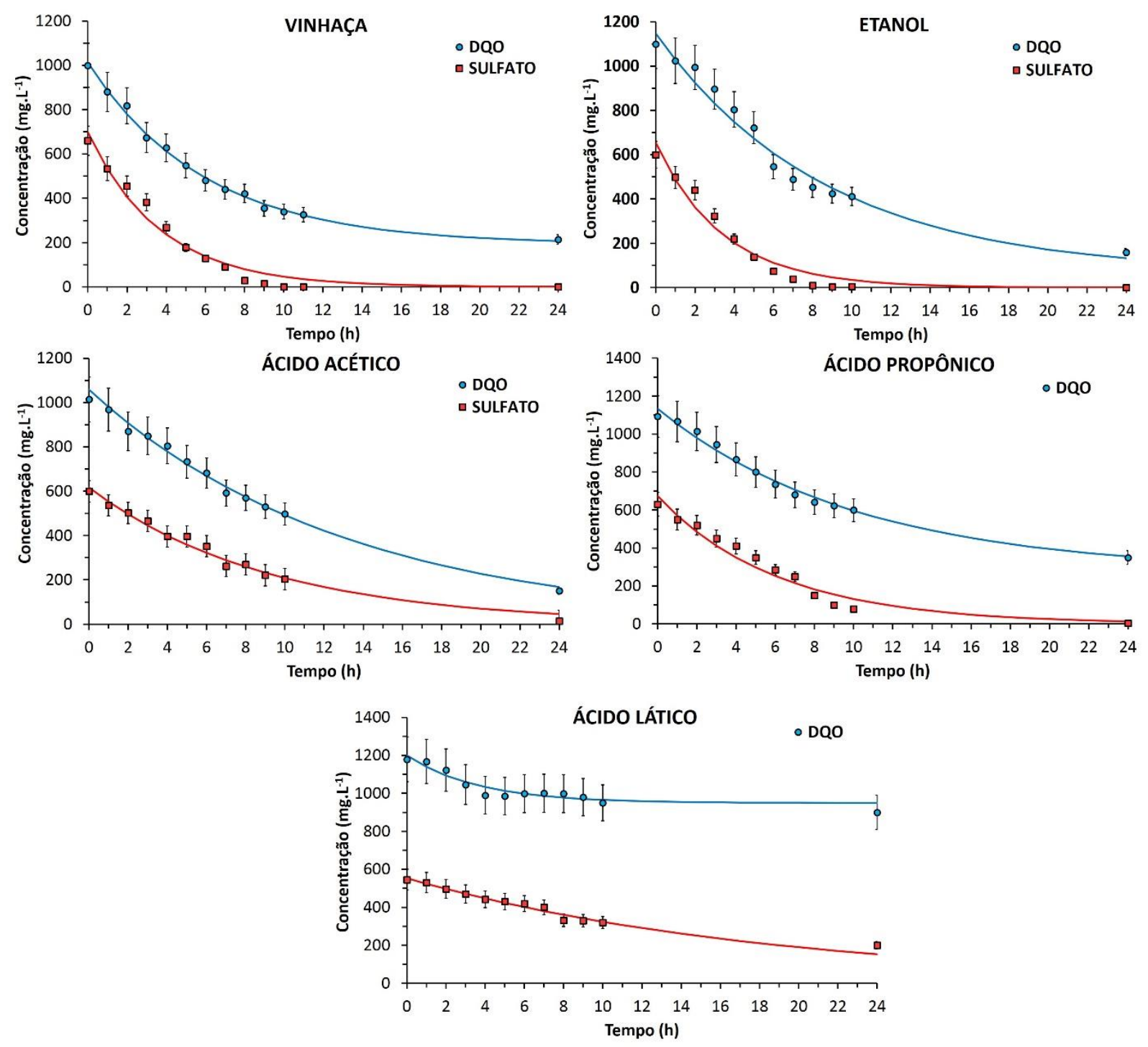

Figura 5.35. Decaimento temporal das concentrações medidas de DQO e sulfato em cada ensaio em batelada. As linhas representam os correspondentes ajustes matemáticos. As barras de erro verticais representam um desvio padrão sistemático estimado em $10 \%$.

Fonte: $\mathrm{O}$ autor.

Os parâmetros de ajuste do modelo cinético $\left(\mathrm{C}^{0}, \mathrm{C}^{\text {Residual }}\right)$, os coeficientes cinéticos aparentes $\left(\mathrm{k}_{1}{ }^{\mathrm{DQO}} \mathrm{e}_{1}{ }^{\mathrm{SO} 4}\right)$ e específicos $\left(\mathrm{ksp}_{1}{ }^{\mathrm{DQO}}\right.$ e $\left.\mathrm{ksp}_{1}{ }^{\mathrm{SO} 4}\right)$, bem como os coeficientes de 
correlação $\left(\mathrm{R}^{2}\right)$ obtidos para a remoção de DQO e sulfato em cada condição testada são apresentados na Tabela 5.11.

Tabela 5.11. Parâmetros obtidos para ajuste dos modelos cinéticos de primeira ordem com residual e sem residual, relativos à remoção de DQO e sulfato, respectivamente.

\begin{tabular}{|c|c|c|c|c|c|}
\hline & Vinhaça & Etanol & Ác. Acético & Ác. Propiônico & Ác. Lático \\
\hline \multicolumn{6}{|c|}{ Cinética de primeira ordem com concentração residual (Remoção de DQO) } \\
\hline $\mathbf{C}^{0}\left(\mathbf{m g} . L^{-1}\right)$ & 1012 & 1147 & 1063 & 1133 & 1199 \\
\hline $\mathrm{C}^{\text {Residual }}\left(\mathbf{m g} . \mathrm{L}^{-1}\right)$ & 192 & 63 & 32 & 272 & 949 \\
\hline $\mathbf{k 1} 1^{\mathrm{DQO}}\left(\mathbf{h}^{-1}\right)$ & 0,167 & 0,115 & 0,081 & 0,098 & 0,273 \\
\hline $\mathbf{R}^{2}$ & 0,995 & 0,959 & 0,993 & 0,987 & 0,912 \\
\hline $\mathrm{k}_{\mathrm{sp1}}^{\mathrm{DQO}}\left(\mathrm{gSSV}^{-1} \cdot \mathrm{h}^{-1}\right)$ & 0,012 & 0,008 & 0,006 & 0,007 & 0,019 \\
\hline \multicolumn{6}{|c|}{ Cinética de primeira ordem sem concentração residual (Remoção de $\mathrm{SO}_{4}^{2-}$ ) } \\
\hline $\mathbf{C}^{0}\left(\mathbf{m g} . L^{-1}\right)$ & 698 & 653 & 617 & 674 & 553 \\
\hline $\mathbf{k} 1^{\mathrm{SO4}}\left(\mathrm{h}^{-1}\right)$ & 0,270 & 0,293 & 0,108 & 0,163 & 0,054 \\
\hline $\mathbf{R}^{2}$ & 0,947 & 0,983 & 0,944 & 0,959 & 0,973 \\
\hline$k_{\mathrm{sp} 1}{ }^{\mathrm{SO} 4}\left(\mathrm{gSSV}^{-1} \cdot \mathrm{h}^{-1}\right)$ & 0,019 & 0,021 & 0,008 & 0,012 & 0,004 \\
\hline
\end{tabular}

Fonte: $\mathrm{O}$ autor.

Os coeficientes de correlação dos modelos matemáticos obtidos tanto para o decaimento de DQO quanto de sulfato indicaram um adequado ajuste do modelo $\left(\mathrm{R}^{2}>0,90\right)$ aos dados experimentais.

A maior constante cinética aparente de remoção de DQO $\left(\mathrm{k} 1^{\mathrm{DQO}}\right)$ foi observada no ensaio utilizando o ácido lático. Todavia, esse doador de elétrons também foi o que resultou em maior concentração residual de DQO solúvel (949 mg. $\left.\mathrm{L}^{-1}\right)$, com baixa eficiência de remoção de matéria orgânica (24\%). Assim, apesar da alta constante cinética aparente, o ácido lático não se mostrou um adequado doador de elétrons para a biomassa estabelecida no DFSBR. 
A segunda maior constante cinética aparente relativa à remoção de DQO foi observada para a vinhaça, a qual apresentou concentração residual cerca de 5 vezes menor que o ácido lático. A eficiência de remoção de DQO nesse ensaio foi de $80 \%$, semelhante às eficiências obtidas ao longo da ETAPA 2, na qual foi estudada a operação contínua do reator. As outras constantes cinéticas aparentes obtidas foram, em ordem decrescente, relativas ao etanol, ao ácido propiônico e, por último, ao ácido acético. As remoções de DQO obtidas ao final do ensaio foram, respectivamente, da ordem de $85 \%$ para o etanol e para o ácido acético, e de $70 \%$ para o ácido propiônico.

Esses resultados indicaram que a biomassa cultivada no reator ao longo da ETAPA 2, alimentado com vinhaça real, pode ser considerada versátil e capaz de degradar diferentes doadores de elétrons, tais como o etanol e os ácidos acético e propiônico, o que pode ser explicado pela ampla variedade de compostos orgânicos presentes na vinhaça (WILKIE et al., 2000).

O consumo dos ácidos acético e propiônico também confirmou a atividade acetotrófica e hidrogenotrófica da comunidade microbiana estabelecida no reator, sendo o ácido propiônico mais rapidamente degradado (maior constante cinética aparente). De fato, a preferência dos organismos redutores de sulfato em executar a oxidação incompleta de etanol, ácido propiônico e outros ácidos orgânicos, com relação à oxidação completa do ácido acético, já foi demonstrada (GHIGLIAZZA et al., 2000; HARADA et al., 1994), o que explica a maior facilidade de remoção desses substratos em sistemas sulfetogênicos. A degradação desses dois ácidos orgânicos é de importância para a manutenção da pressão parcial do hidrogênio sob controle no meio líquido, representando uma vantagem na ocorrência de sobrecargas orgânicas no sistema.

No caso da remoção de sulfato pelo DFSBR, as constantes cinéticas aparentes obtidas indicaram o etanol como o doador de elétrons preferencial para a redução de sulfato. A razão 
entre as constantes cinéticas aparentes de redução de sulfato a partir da vinhaça e do etanol foi da ordem de $1,1\left(\mathrm{k}_{1}{ }_{\text {ETANOL }}^{\text {SO }} \mathrm{k}_{1}{ }_{\text {VINHAÇA }}\right)$. Ácido propiônico e ácido acético foram, nessa ordem, os outros doadores de elétrons favoráveis para a sulfetogênese, com as respectivas constantes cinéticas aparentes da ordem de $0,6\left(\mathrm{k}_{1}{ }^{\mathrm{SO}}{ }_{\text {PROPIÔNICO }} / \mathrm{k}_{1}{ }^{\mathrm{SO} 4}\right.$ VINHAÇA $)$ e 0,4 $\left(\mathrm{k}_{1}{ }^{\mathrm{SO} 4}{ }_{\text {ACÉTICO }} / \mathrm{k}_{1}{ }^{\mathrm{SO} 4}{ }_{\text {VINHAÇA }}\right)$ em relação à constante observada para a vinhaça.

É importante notar que, nos ensaios com vinhaça, etanol, ácido acético e propiônico, o sulfato disponível foi praticamente esgotado, com concentrações finais abaixo do limite de detecção do método empregado $\left(\mathrm{LD}=2 \mathrm{mg} \cdot \mathrm{L}^{-1}\right)$, ou seja, eficiências de remoção próximas de 100\%, em metade do tempo de ensaio (12 h). Esses 4 doadores de elétrons testados foram adequados para a viabilização da redução de sulfato, comprovando a versatilidade dos organismos redutores de sulfato cultivados no biofilme do DFSBR sob as condições de operação do reator. Também BRS acetotróficas, geralmente apontadas como de difícil obtenção em reatores sulfetogênicos (CAO et al., 2012; DAMIANOVIC; FORESTI, 2009; OMIL et al., 1998), se mostraram presentes e atuantes, uma vez que o reator foi capaz de reduzir sulfato na presença de ácido acético como único doador de elétrons.

Embora a redução de sulfato a partir do ácido acético tenha sido a que resultou em menor constante cinética aparente com relação aos outros três substratos, a metanogênese acetoclástica se mostrou capaz de remover o ácido acético remanescente da fase líquida, com ganho para a eficiência de remoção de DQO o sistema.

Por fim, a constante cinética aparente de remoção de sulfato a partir do ácido lático foi expressivamente menor $\left(\mathrm{k}_{1}{ }^{\mathrm{SO} 4}\right.$ LÁTICO $/ \mathrm{k}_{1}{ }^{\mathrm{SO} 4}$ VINHAÇA $\left.=0,2\right)$, indicando a inabilidade da biomassa redutora de sulfato cultivada no DFSBR de utilizar esse substrato como doador de elétrons. A eficiência de remoção de sulfato de $63 \%$, obtida a partir desse substrato, também indicou a menor afinidade da biomassa pelo ácido lático em comparação com os outros doadores de elétrons testados. 
Considerando que para cada $1 \mathrm{mg}$ de $\mathrm{SO}_{4}{ }^{2-}$ reduzido, 0,67 $\mathrm{mg}$ de DQO são oxidadas, estimou-se a participação da sulfetogênese e metanogênese no processo de remoção de matéria orgânica. Nos ensaios testando vinhaça, etanol e ácidos acético e propiônico, a participação de ambas as vias de remoção de DQO foram praticamente similares (próximas de $50 \%$ cada via), indicando uma associação equilibrada entre metanogênese e sulfetogênese promovida pela relação $\mathrm{DQO} / \mathrm{SO}_{4}{ }^{2-}$ próxima de 2,0. De fato, para a vinhaça, a DQO foi removida $51 \%$ pela via metanogênica e $49 \%$ pela via de redução de sulfato. Etanol e ácido acético favoreceram moderadamente a remoção de DQO pela via metanogênica (57\% e 55\%, respectivamente), enquanto que o ácido propiônico foi removido com maior preferência pela via sulfetogênica (56\%). Já a remoção marginal de matéria orgânica no ensaio com ácido lático se deu quase exclusivamente pela via sulfetogênica (83\%). Assim, além da menor atividade redutora de sulfato a partir de ácido lático, também a metanogênese foi inibida pelo substrato em questão, o que pode ser atribuído à menor adaptação do inóculo ao referido ácido orgânico. Tal observação é semelhante ao resultado reportado por ZHANG et al. (2007), o qual avaliou o efeito do ácido lático sobre a biomassa metanogênica. Os autores observaram prejuízo da atividade metanogênica do lodo anaeróbio, bem como a dificuldade em processar maiores cargas orgânicas quando o reator foi alimentado com afluente constituído por 50\% de ácido lático (em termos de DQO), o que não foi observado no reator de controle alimentado com glicose ao invés de ácido lático (ZHANG et al., 2007).

$\mathrm{O}$ pH final dos ensaios em batelada foram similares ao $\mathrm{pH}$ de início do ensaio $(\approx 7,20)$ no caso da vinhaça $(\approx 7,50)$ e do ácido propiônico $(\approx 7,00)$. No caso dos ensaios a partir de etanol e ácido acético, o pH do meio líquido foi elevado para próximo de 7,70 e 8,60, respectivamente. A alta produção de alcalinidade pela via de oxidação completa da DQO pelas BRS, conforme indicado nas Equações (3.8) e (3.9), deve estar relacionada com a expressiva elevação do pH observada nessas duas últimas condições. 
Por outro lado, a acidificação da fase líquida, observada quando foi utilizado o ácido lático $(\mathrm{pH}$ final $\approx 6,50$ ), pode ser considerado o fator responsável pelo pior desempenho do sistema nessa condição. Esse resultado também sugeriu a maior demanda por alcalinidade quando ácido lático foi dosado como doador de elétrons para a sulfetogênese, o que pode estar ligado ao estabelecimento de processos fermentativos/acetogênicos além da redução de sulfato (ZAO et al., 2008).

O deslocamento da forma ionizada do sulfeto dissolvido $\left(\mathrm{HS}^{-}\right)$para a sua forma molecular $\left(\mathrm{H}_{2} \mathrm{~S}\right)$ (Figura 3.3), por sua vez, também pode levar à restrição dos processos metanogênicos e sulfetogênicos (REIS et al., 1992; HILTON; OLESZKIEWICZ, 1988).

Considerando que para cada $1 \mathrm{mg}$ de $\mathrm{SO}_{4}{ }^{2-}$ reduzido, cerca de $0,33 \mathrm{mg}$ de sulfeto são gerados, as concentrações estimadas de sulfeto total dissolvido ao final dos ensaios foram de cerca de 130 mgSTD.L ${ }^{-1}$ (ácido lático), $210 \mathrm{mgSTD}^{-1}$ (ácido propiônico), $200 \mathrm{mgSTD} . \mathrm{L}^{-1}$ (ácido acético e etanol) e $190 \mathrm{mgSTD} . \mathrm{L}^{-1}$ (vinhaça). Por outro lado, considerando o $\mathrm{pH}$ da fase líquida ao final dos mesmos ensaios, a concentração estimada de $\mathrm{H}_{2} \mathrm{~S}$ molecular (conforme os cálculos apresentados na subseção 4.13.3, p. 99) foi de $104 \mathrm{mgH}_{2} \mathrm{~S}_{\text {.L }}{ }^{-1}$ (ácido lático), $110 \mathrm{mgH}_{2} \mathrm{~S} . \mathrm{L}^{-1}$ (ácido propiônico), $5 \mathrm{mgH}_{2} \mathrm{~S} . \mathrm{L}^{-1}$ (ácido acético), $35 \mathrm{mgH}_{2} \mathrm{~S} . \mathrm{L}^{-1}$ (etanol) e $48 \mathrm{mgH}_{2} \mathrm{~S} . \mathrm{L}^{-1}$ (vinhaça). Assim, a concentração da forma molecular do sulfeto de hidrogênio, capaz de permear mais facilmente a membrana plasmática dos microrganismos e resultar em efeitos tóxicos e inibitórios (KOSCHORRECK, 2008), foi mais pronunciado tanto durante o ensaio utilizando ácido propiônico quanto com ácido lático, de forma que a presença de sulfeto molecular acima de $100 \mathrm{mg} . \mathrm{L}^{-1}$ não pode ser apontada como sendo responsável pelo pior desempenho da biomassa ao longo do ensaio com ácido lático.

Por fim, pode-se afirmar que a biomassa cultivada no DFSBR alimentado com vinhaça para o tratamento de uma DAM sintética apresentou versatilidade e capacidade de processar outros doadores de elétrons de forma exclusiva. Alta afinidade pelo etanol foi observada, 
enquanto ácido lático não foi eficazmente removido do sistema provavelmente devido à falta de adaptação da biomassa ao substrato e aos efeitos deletérios do baixo valor de $\mathrm{pH}$ final do ensaio. O consumo dos ácidos acético e propiônico, por sua vez, indicaram atividade acetotrófica e hidrogenotrófica tanto pelas vias de redução de sulfato quando pela metanogênese.

\subsubsection{Considerações finais relativas à ETAPA 2}

O padrão hidrodinâmico do reator anaeróbio de leito fixo-estruturado e escoamento descendente (DFSBR) operando sob as cargas orgânicas e de sulfato testadas se mostrou próximo da mistura completa. Esse padrão foi mais pronunciado nas fases com altas razões de recirculação. Todavia, mesmo durante a fase operacional sem reciclo o reator apresentou comportamento de mistura, o que foi atribuído à produção de biogás pela metanogênese ativa no sistema.

As maiores razões de recirculação testadas não proporcionaram aumento relevante das eficiências de remoção de ferro. Ao contrário, maiores razões de reciclo implicaram na ressuspensão do material precipitado, bem como no retorno e deposição dos sulfetos metálicos sobre o material suporte. A fase operada sem reciclo, por sua vez, foi a que apresentou as maiores eficiências de remoção de ferro (da ordem de 96\%). Essas observações refutaram a sub-hipótese 2A: Maiores razões de recirculação proporcionarão condições mais efetivas de arraste dos sulfetos metálicos formados no reator, evitando sua deposição sobre o biofilme e possibilitando uma recuperação mais significativa dos mesmos.

Assim, durante as próximas fases operacionais o DFSBR será mantido sem reciclo da fase líquida. Esse resultado também se revelou uma característica favorável do DFSBR, permitindo o tratamento de DAM rica em metais sem a manutenção de altas vazões de recirculação. 
O estudo da influência de diferentes razões de recirculação sobre o desempenho do sistema indicou o maior desprendimento da biomassa do DFSBR associado ao aumento das velocidades superficiais de escoamento. Todavia, apesar da maior perda de SSV, o que acarretou em menores concentrações de biomassa no material suporte e no aumento da DQO remanente no efluente do reator, o DFSBR foi capaz de manter adequada remoção de sulfato em níveis próximos dos obtidos durante a fase operada sem reciclo. O sistema tampouco apresentou desequilíbrios na digestão anaeróbia ou inibição da metanogênese pelas altas velocidades superficiais do escoamento. Dessa forma, a sub-hipótese 2B - Excessivas velocidades superficiais de escoamento poderão afetar negativamente a estabilidade do processo biológico, promovendo o desprendimento do biofilme, com prejuízo para o processo biológico - foi parcialmente contrariada, o que foi atribuído à adequada aderência do biofilme ao material suporte utilizado, indicando a sua viabilidade para o estabelecimento associado de populações metanogênicas e redutoras de sulfato.

Por fim, a introdução da DAM sintética no sistema alimentado com vinhaça de canade-açúcar favoreceu o aumento da participação das BRS na degradação global da matéria orgânica, com aumento nas eficiências de remoção de sulfato, as quais chegaram a valores próximos de $100 \%$, ressaltando o potencial do DFSBR operando com vinhaça real como doador de elétrons para a sulfetogênese.

Os ensaios cinéticos do reator DFSBR em batelada corroboraram a versatilidade da biomassa cultivada no DFSBR a partir de vinhaça e sob condições sulfetogênicas e metanogênicas associadas (relação $\mathrm{DQO} / \mathrm{SO}_{4}{ }^{2-} \approx 2,0$ ). Etanol se mostrou um doador de elétrons preferencial para a redução de sulfato. O consumo de ácido acético associado à redução de sulfato foi um forte indicativo da atividade acetotrófica da biomassa sulfetogênica 
desenvolvida no reator, a qual, em conjunto com a metanogênese acetoclástica, foram responsáveis pelo alcance das altas remoções de matéria orgânica observadas. Ácido propiônico também foi removido pelas vias metabólicas sulfetogênica e metanogênica, o que é desejável para a manutenção da digestão anaeróbia equilibrada. Dentre os testados, apenas o ácido lático não se mostrou um doador de elétrons efetivo para a biomassa do DSFBR, o que foi atribuído à expressiva acidificação da fase líquida.

Em todo caso, a vinhaça de cana-de-açúcar foi considerada um substrato adequado como doador de elétrons para o tratamento de DAM, favorecendo o estabelecimento de uma biomassa diversificada, com potencial de degradação de diferentes compostos pela via de redução de sulfato concomitantemente à metanogênese, validando a sub-hipótese 2C: $A$ vinhaça é uma água residuária com conteúdo orgânico e mineral passível de ser utilizada como doador de elétrons, fonte exclusiva de carbono e nutrientes para o tratamento biológico de uma DAM, possibilitando o estabelecimento de uma biomassa versátil, com a associação de processos sulfetogênicos e metanogênicos no sistema. 


\subsection{ETAPA 3: Influência do pH afluente sobre o desempenho do DFSBR}

Durante a ETAPA 3 o reator DFSBR foi alimentado com vinhaça de cana-de-açúcar como única fonte de carbono e nutrientes para o processo biológico, tendo sido o sistema submetido à diminuição gradual do $\mathrm{pH}$ afluente $(\mathrm{pH}$ AFLUENTE $=6,3 \rightarrow 3,5)$ para avaliação da estabilidade e robustez do processo sob condições ácidas, simulando o tratamento de uma DAM real. Também se pretendeu verificar a produção de alcalinidade pela sulfetogênese estabelecida no reator a partir da vinhaça como fator chave para o sucesso do tratamento biológico de uma DAM sem adição externa de álcali (Objetivo específico 3: Sub-hipótese $\underline{3 \mathrm{~A}})$.

A influência do abaixamento do $\mathrm{pH}$ afluente do reator sobre os processos de precipitação e separação do sulfeto de ferro no DFSBR também foram verificados (Subhipótese 3B: Objetivo específico 3B).

Os efeitos da supressão total na dosagem de álcali e da acidificação do meio líquido sobre as populações microbianas estabelecidas no DFSBR também foram avaliados, bem como a viabilidade da manutenção da metanogênese no sistema com restrição de alcalinidade (Sub-hipótese 3C).

Durante essa etapa, o reator foi mantido sem recirculação da fase líquida, uma vez que a ETAPA 2 permitiu comprovar o desempenho adequado do DFSBR nessa condição, com melhor estabilidade e eficiência de remoção de ferro.

\subsubsection{Desempenho do DFSBR submetido à diminuição do pH afluente}

A Figura 5.36 apresenta o desempenho geral do reator DFSBR na remoção de matéria orgânica e sulfato ao longo da ETAPA 3, operada com abaixamento gradual do pH afluente. 


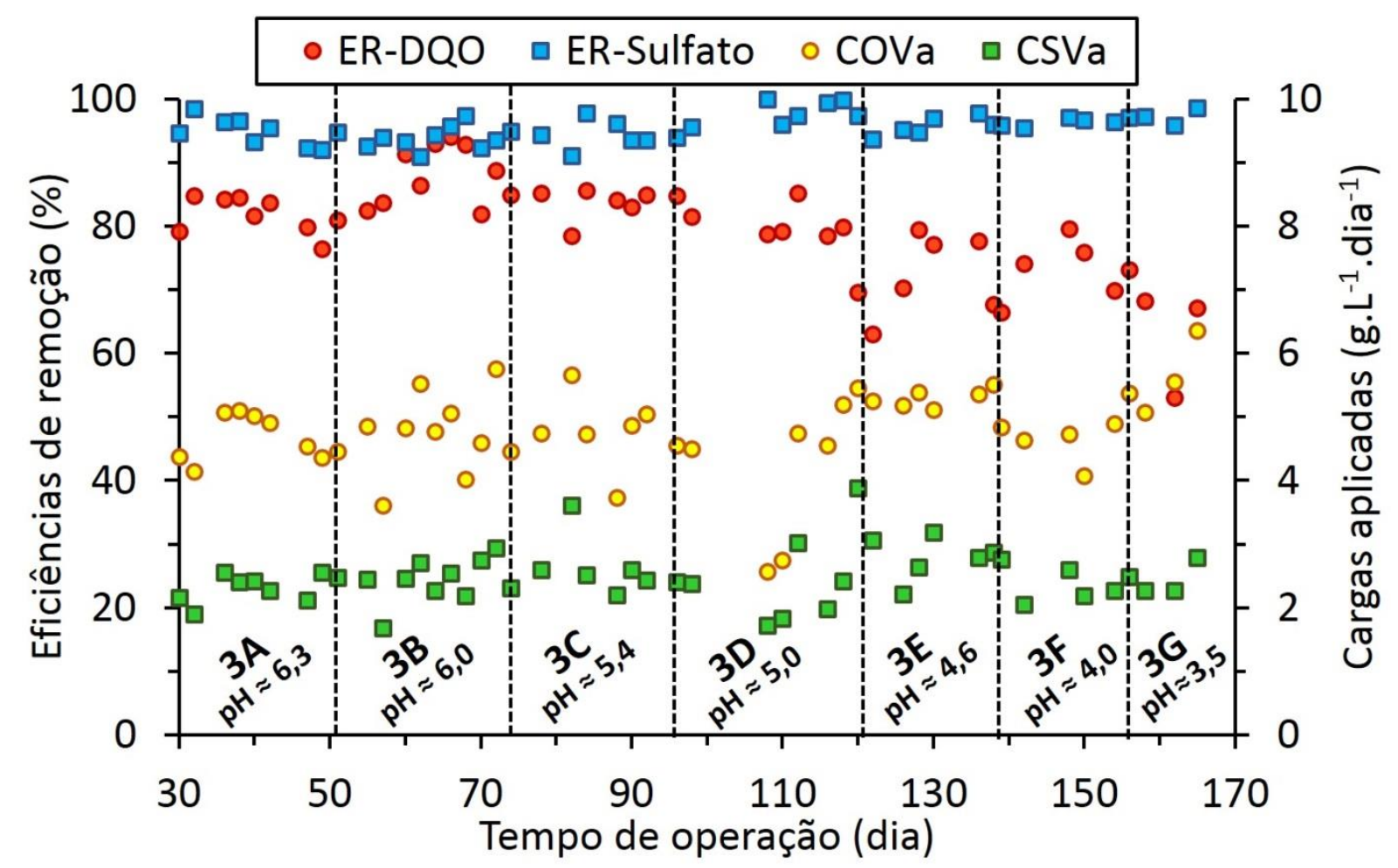

Figura 5.36: Eficiências de remoção de DQO (ER-DQO) e sulfato (ER-Sulfato), e cargas volumétricas aplicadas de matéria orgânica (COVa) e sulfato (CSVa) ao longo da ETAPA 3, operada com diminuição gradual do $\mathrm{pH}$ afluente.

Fonte: $\mathrm{O}$ autor.

Após a inoculação do material suporte, realizada conforme procedimento já apresentado anteriormente (seção 4.4), o reator foi mantido durante cerca de 50 dias sendo alimentado com vinhaça $\left(4100 \pm 450 \mathrm{mg}\right.$ DQO. $\left.\mathrm{L}^{-1}\right)$ e recebendo complementação de sulfato para manutenção de uma relação $\mathrm{DQO} / \mathrm{SO}_{4}{ }^{2-}$ da ordem de $2,0 . \mathrm{O} \mathrm{pH}$ afluente foi mantido próximo de 6,3 com dosagem de $\mathrm{NaOH} 12 \mathrm{M}$ (FASE 3A). Em seguida, durante as FASES 3B a 3G, DAM sintética passou a ser introduzida, com concentração de ferro afluente da ordem de $260 \mathrm{mg} \cdot \mathrm{L}^{-1}$. O pH afluente foi sendo gradativamente diminuído em cada fase, até a completa supressão da dosagem de $\mathrm{NaOH}$. Durante as FASES 3F e 3G, $\mathrm{HCl} 6 \mathrm{M}$ foi dosado para a diminuição do $\mathrm{pH}$ da vinhaça diluída (próximo de 4,50) até os valores de $\mathrm{pH}$ a serem estudados $(4,0$ e 3,5), simulando a introdução de uma DAM com acidez mais pronunciada no sistema. 
A Tabela 5.12 apresenta os dados resumidos relativos às eficiências de remoção de matéria orgânica e sulfato ao longo das condições estudadas na ETAPA 3.

Tabela 5.12. Cargas orgânicas volumétricas aplicadas (COVa) e removidas (COVr), cargas de sulfato volumétricas aplicadas (CSVa) e removidas (CSVr) e eficiências de remoção de DQO (ER-DQO) e sulfato (ER-Sulfato) obtidas durante a ETAPA 3.

\begin{tabular}{|c|c|c|c|c|c|c|c|}
\hline FASES & $\begin{array}{l}\text { pH afluente } \\
\text { / pH interno }\end{array}$ & $\begin{array}{l}\text { COVa } \\
\text { (gDQ }\end{array}$ & $\begin{array}{l}\operatorname{COVr} \\
\left.\cdot \mathrm{L}^{-1} \cdot \mathrm{d}^{-1}\right)\end{array}$ & $\begin{array}{c}\text { ER-DQO } \\
(\%)\end{array}$ & $\begin{array}{l}\text { CSVa } \\
\text { (gSO }\end{array}$ & $\begin{array}{l}\text { CSVr } \\
\left.L^{-1} \cdot d^{-1}\right)\end{array}$ & $\begin{array}{c}\text { ER-Sulfato } \\
(\%)\end{array}$ \\
\hline $2 A$ & $6,30 / 7,20$ & $4,6 \pm 0,2$ & $3,7 \pm 0,3$ & $81 \pm 3$ & $2,4 \pm 0,2$ & $2,2 \pm 0,2$ & $94 \pm 2$ \\
\hline 2B & $6,00 / 7,30$ & $4,7 \pm 0,6$ & $4,2 \pm 0,6$ & $89 \pm 5$ & $2,4 \pm 0,4$ & $2,3 \pm 0,3$ & $94 \pm 2$ \\
\hline $2 \mathrm{C}$ & $5,40 / 7,20$ & $4,8 \pm 0,6$ & $4,0 \pm 0,4$ & $83 \pm 2$ & $2,6 \pm 0,5$ & $2,5 \pm 0,4$ & $94 \pm 2$ \\
\hline 2D & $5,00 / 7,10$ & $4,3 \pm 1,0$ & $3,3 \pm 0,9$ & $79 \pm 5$ & $2,5 \pm 0,8$ & $2,4 \pm 0,7$ & $98 \pm 2$ \\
\hline $2 E$ & $4,60 / 6,90$ & $5,2 \pm 0,2$ & $3,8 \pm 0,4$ & $72 \pm 6$ & $2,8 \pm 0,3$ & $2,7 \pm 0,3$ & $96 \pm 1$ \\
\hline $2 F$ & $4,00 / 6,80$ & $4,6 \pm 0,4$ & $3,4 \pm 0,3$ & $75 \pm 4$ & $2,3 \pm 0,2$ & $2,2 \pm 0,2$ & $96 \pm 1$ \\
\hline $2 G$ & $3,50 / 6,50$ & $5,3 \pm 0,2$ & $3,6 \pm 0,6$ & $67 \pm 9$ & $2,5 \pm 0,2$ & $2,4 \pm 0,3$ & $97 \pm 1$ \\
\hline
\end{tabular}

Fonte: $\mathrm{O}$ autor.

Durante a primeira fase da ETAPA 3 (FASE $3 \mathrm{~A}-\mathrm{pH}$ AFLUENTE $\approx 6,3$ ), o reator apresentou eficiência de remoção de DQO de $81 \pm 3 \%$. Após a introdução da DAM sintética, promovendo a precipitação dos sulfetos complexados com o ferro, melhoria na eficiência de DQO foi notada, de maneira semelhante ao observado durante a ETAPA 2. Assim, durante a FASE 3B $\left(\mathrm{pH}_{\text {AFLUENTE }} \approx 6,0\right)$ a eficiência de remoção de DQO do DFSBR foi de $89 \pm 5 \%$, enquanto na FASE $3 \mathrm{C}$ esse valor foi de $83 \pm 2 \%$ ( $\mathrm{pH}$ AFLUENTE $\approx 5,4)$. O decréscimo do $\mathrm{pH}$ afluente passou a afetar negativamente a remoção de DQO no sistema a partir da FASE 3D $\left(\mathrm{pH}_{\text {AFLUENTE }} \approx 5,0\right)$ em diante, conforme ilustrado pela Figura 5.37a. Com o decréscimo do pH, as eficiências médias de remoção de DQO se mantiveram próximas de $74 \pm 6 \%$ durante as FASES 3D, 3E e 3F (pH AFLUENTE $\approx 5,0,4,6$ e 4,0, respectivamente). Já durante a FASE 3F $\left(\mathrm{pH}_{\mathrm{AFLUENTE}} \approx 3,5\right)$ a eficiência de remoção de matéria orgânica foi de $67 \pm 9 \%$. De fato, as análises estatísticas indicaram que as eficiências de remoção de DQO obtidas durante as 
FASES 3A a 3C foram significativamente diferentes $(\mathrm{p}<0,05)$ das eficiências obtidas durante as FASES 3D a 3G.

Por outro lado, as eficiências de remoção de sulfato durante toda a ETAPA 3 se mantiveram próximas de 94\% (FASES 3A a 3C), ou mesmo superiores a esse valor (FASES 3D a 3G), conforme mostrado na Figura 5.37b. Não foram observadas diferenças estatisticamente significativas ( $p$ > 0,05) entre as eficiências de remoção de sulfato obtidas em todas as fases operacionais da ETAPA 3. Assim, a supressão na dosagem de álcali externo não parece ter afetado os processos de remoção de sulfato estabelecidos no reator, o que pode estar relacionado ao maior potencial de adaptação das BRS às condições mais restritivas de pH (MEIER et al., 2012; ELLIOT et al., 1998). A diminuição gradual do pH afluente também pode ser considerada uma estratégia adequada para a adaptação das BRS provenientes do inóculo cultivado em reator operado próximo da neutralidade (VIEIRA et al., 2016). 
(a)

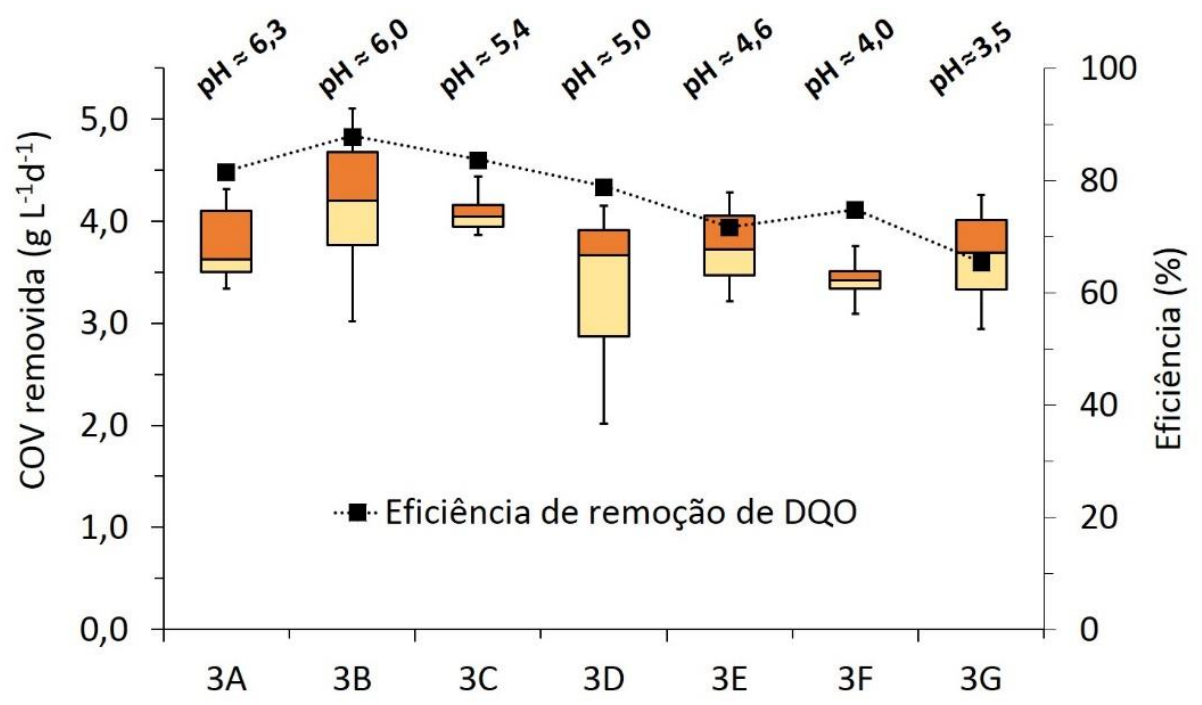

(b)

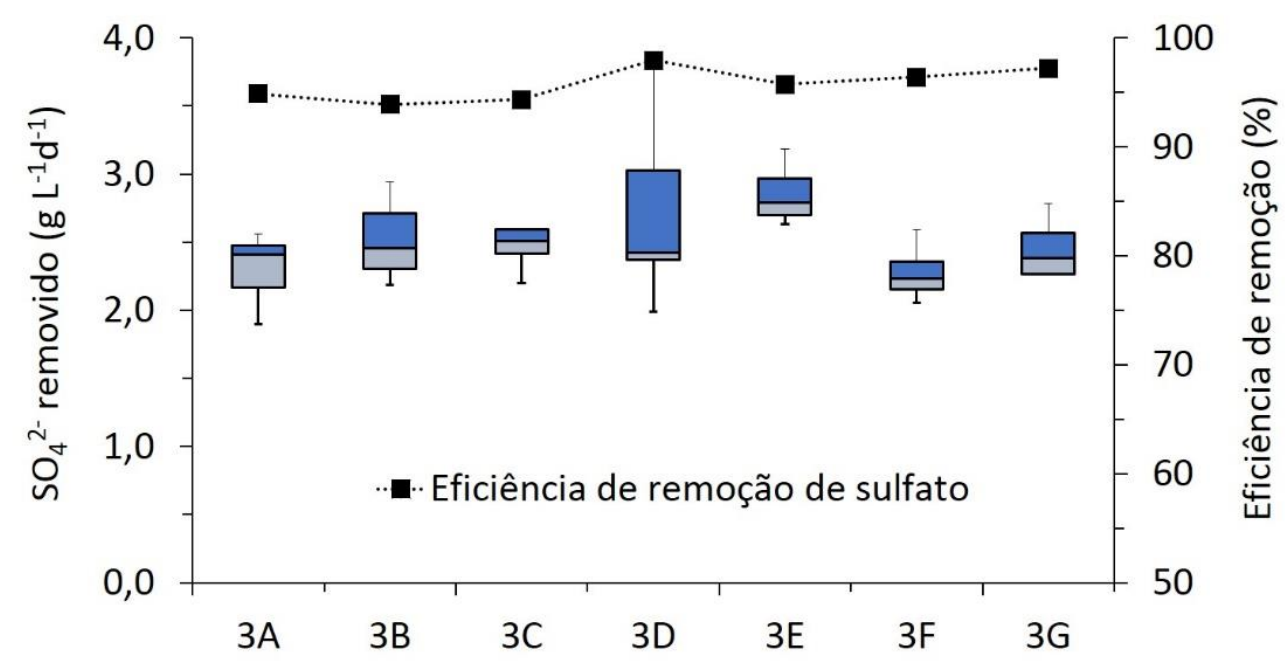

Figura 5.37. Desempenho geral do DFSBR: (a) Análise estatística de Boxplot das cargas orgânicas removidas (COVr) e eficiências médias de remoção de DQO durante a ETAPA 3; e (b) Análise estatística de Boxplot das cargas de sulfato removidas (CSVr) e eficiências médias de remoção de sulfato durante a ETAPA 3.

Fonte: $\mathrm{O}$ autor.

A observação dos resultados até aqui apresentados permite inferir que a diminuição do pH afluente, embora não tenha afetado a biomassa sulfetogênica, pode ter impactado o metabolismo dos microrganismos metanogênicos, com prejuízo da remoção de DQO por essa via. A Figura 5.38 mostra a distribuição do fluxo de elétrons (remoção de DQO) pelas vias metanogênica e sulfetogênica, bem como para produção de SSV no DFSBR durante a 
ETAPA 3. Observa-se que o decaimento no $\mathrm{pH}$ afluente implicou em diminuição da participação da metanogênese no processo global de conversão da matéria orgânica. Enquanto durante as FASES 3A, 3B e 3C a participação da metanogênese na remoção de DQO foi, em média, de 52\%, 56\% e 50\%, respectivamente, essa participação foi da ordem de $35 \%$ durante as FASES 3D, 3E e 3F, e de 25\% durante a FASE 3G. Já a redução de sulfato foi responsável pela remoção de cerca de $40 \%$ da DQO convertida durante as FASES 3A a 3C, aumentando sua participação para cerca de $46 \%$ durante as fases subsequentes, operadas com menores valores de $\mathrm{pH}$ afluente. Assim, a inibição parcial das arqueias metanogênicas pode ter contribuído para o aumento da participação das BRS no processo de remoção de DQO, possivelmente pelas vantagens desses microrganismos na competição pelo substrato disponível sob as condições mais ácidas do sistema (SÁNCHEZ-ANDREA et al., 2014).

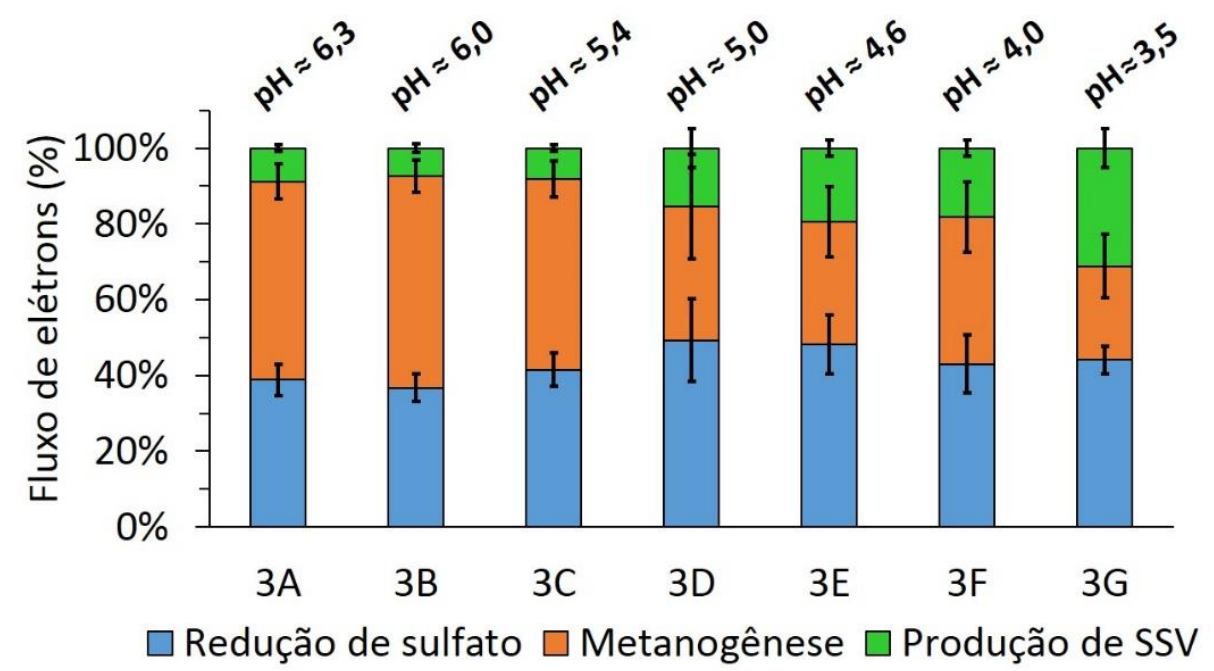

Figura 5.38. Distribuição do fluxo de elétrons no DFSBR (em porcentagem de DQO) para as vias de redução de sulfato, metanogênese e produção de sólidos suspensos voláteis (SSV) em cada fase da ETAPA 3. As barras de erros representam o desvio-padrão.

Fonte: $\mathrm{O}$ autor.

Os valores de $\mathrm{pH}$ medidos no interior do reator foram da ordem de 7,2 durante as primeiras fases da ETAPA 3 (3A a 3D), caindo para próximo de 6,9 durante as FASES 3E e 3F (Tabela 5.13). Durante a última fase dessa mesma ETAPA (3G) o pH medido no líquido 
interno do reator foi da ordem de 6,5 (Tabela 5.13). Dessa forma, a diminuição do $\mathrm{pH}$ afluente por supressão na dosagem externa de álcali não implicou em diminuição expressiva do $\mathrm{pH}$ interno do reator até a FASE 3G, apesar da queda na participação da metanogênese no processo de remoção de DQO do reator (Figura 5.38).

Por outro lado, o aumento da concentração de SSV no efluente do reator ao longo da ETAPA 3 indicou a intensificação do desprendimento e arraste de biomassa durante as FASES 3D a 3G (Tabela 5.13), o que implicou no desvio de uma maior parcela de DQO consumida para os processos de assimilação e síntese celular (Figura 5.38).

Tabela 5.13. Valores de pH nas correntes afluente e efluente do DFSBR e no meio líquido interno, bem como concentrações de SSV medidas no efluente do reator durante a ETAPA 3.

\begin{tabular}{lllll}
\hline $\begin{array}{l}\text { Fase } \\
\text { Operacional }\end{array}$ & $\mathbf{p H}$ afluente & $\mathbf{p H}$ interno & pH efluente & $\begin{array}{l}\text { SSV no efluente } \\
\left(\mathbf{m g} . \mathbf{L}^{-1} \text { ) }\right.\end{array}$ \\
\hline 3A & $6,3 \pm 0,4$ & $7,2 \pm 0,1$ & $8,1 \pm 0,2$ & $210 \pm 50$ \\
\hline 3B & $6,0 \pm 0,1$ & $7,3 \pm 0,1$ & $8,0 \pm 0,2$ & $180 \pm 130$ \\
\hline 3C & $5,4 \pm 0,1$ & $7,2 \pm 0,1$ & $7,7 \pm 0,1$ & $200 \pm 150$ \\
\hline 3D & $5,0 \pm 0,1$ & $7,1 \pm 0,1$ & $7,4 \pm 0,2$ & $300 \pm 120$ \\
\hline 3E & $4,6 \pm 0,1$ & $6,9 \pm 0,2$ & $7,3 \pm 0,2$ & $420 \pm 90$ \\
\hline 3F & $4,0 \pm 0,1$ & $6,8 \pm 0,1$ & $7,2 \pm 0,3$ & $520 \pm 300$ \\
\hline 3G & $3,5 \pm 0,1$ & $6,5 \pm 0,1$ & $6,9 \pm 0,3$ & $560 \pm 120$ \\
\hline
\end{tabular}

Fonte: $\mathrm{O}$ autor.

Mesmo sob as condições mais restritivas impostas pela diminuição do $\mathrm{pH}$ afluente e apesar do impacto observado sobre a metanogênese no DFSBR durante a ETAPA 3, não foi observada a completa supressão do metabolismo metanogênico. Embora em menor proporção, a metanogênese foi capaz de manter uma atividade parcial, contribuindo para a remoção de uma fração de matéria orgânica convertida a biogás, conforme mostrado na Figura 5.39. 


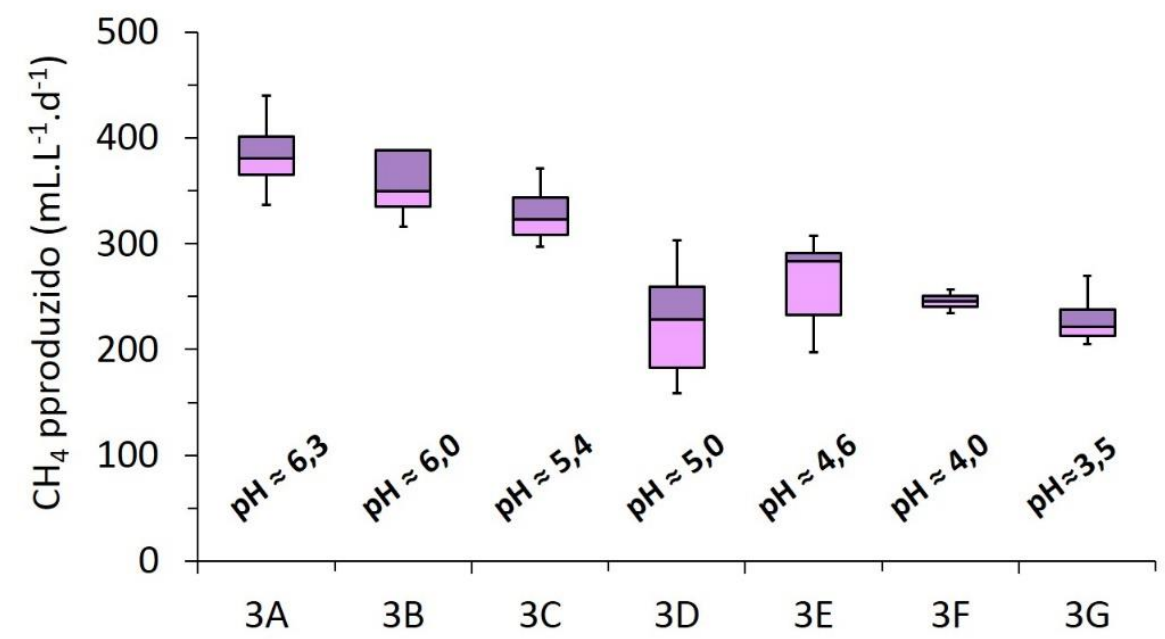

Figura 5.39: Análise estatística de Boxplot da produção volumétrica de metano da ETAPA 3. Dados corrigidos para as CNTP $\left(0^{\circ} \mathrm{C}\right.$ e $\left.1 \mathrm{~atm}\right)$.

Fonte: $\mathrm{O}$ autor.

A produção volumétrica de metano (nas CNTP) medida no sistema passou de cerca de $380 \mathrm{~mL} . \mathrm{L}^{-1}$ reator. $\mathrm{d}^{-1}$, durante a primeira fase, para próximo de $230 \mathrm{~mL} . \mathrm{L}^{-1}$ reator. $\mathrm{d}^{-1}$ na última fase, em função da queda da participação da metanogênese na remoção de DQO (Figura 5.38).

A variação na composição do biogás produzido durante a ETAPA 3 pode ser verificada na Tabela 5.14. A diminuição da porcentagem de metano no biogás gerado foi acompanhada do aumento da concentração de gás carbônico, o que pode ser atribuído à diminuição do $\mathrm{pH}$ do meio líquido, com o deslocamento do equilíbrio químico do carbonato/bicarbonato, o qual passou da forma de $\mathrm{HCO}_{3}{ }^{-}$para $\mathrm{CO}_{2}$, sendo mais facilmente perdido para a fase gasosa. 
Tabela 5.14. Variação na composição média do biogás do DFSBR durante a ETAPA 3.

\begin{tabular}{llll}
\hline $\begin{array}{l}\text { Fase } \\
\text { Operacional }\end{array}$ & $\mathbf{C H}_{\mathbf{4}}$ & $\mathbf{C O}_{2}$ & $\mathbf{H}_{2} \mathbf{S}$ \\
\hline $3 \mathrm{~A}$ & $60 \pm 3 \%$ & $20 \pm 1 \%$ & $6 \pm 0 \%$ \\
\hline 3B & $58 \pm 6 \%$ & $25 \pm 3 \%$ & $5 \pm 1 \%$ \\
\hline $3 \mathrm{C}$ & $57 \pm 4 \%$ & $30 \pm 2 \%$ & $6 \pm 1 \%$ \\
\hline 3D & $50 \pm 2 \%$ & $30 \pm 2 \%$ & $5 \pm 1 \%$ \\
\hline 3E & $46 \pm 6 \%$ & $33 \pm 5 \%$ & $5 \pm 1 \%$ \\
\hline $3 \mathrm{~F}$ & $41 \pm 2 \%$ & $36 \pm 3 \%$ & $5 \pm 0 \%$ \\
\hline $3 \mathrm{G}$ & $44 \pm 2 \%$ & $39 \pm 1 \%$ & $4 \pm 0 \%$ \\
\hline
\end{tabular}

Fonte: $\mathrm{O}$ autor.

De fato, os microrganismos metanogênicos são comumente caracterizados como fortemente dependentes de um $\mathrm{pH}$ próximo da neutralidade, sendo a faixa ótima de $\mathrm{pH}$ para o metabolismo metanogênico entre os valores 6,6 e 7,4 (CHERNICHARO, 2007). No entanto, as arqueias metanogênicas também são capazes de atuar em uma faixa de $\mathrm{pH}$ mais ampla, de 6,0 a 8,0, tendo já sido reportada, inclusive, a viabilidade do seu metabolismo em condições de $\mathrm{pH}$ acentuadamente mais ácido $(<6,0)$, o que foi obtido após longos períodos de aclimatação (TACONI et al., 2008; JAIN; MATTIASSON, 1998).

JAN e MATTIASSON (1998), por exemplo, reportaram uma queda da ordem de $10 \%$ na produção de metano após a diminuição do pH de 7,0 para 6,5 durante o tratamento anaeróbio de uma água residuária da indústria de papel. Diminuições sucessivas no pH do reator para 6,0, 5,5 e 5,0, por sua vez, resultaram em decréscimos na produção de metano da ordem de $20 \%, 29 \%$ e $42 \%$, respectivamente, em relação ao metano produzido em pH 7,0 (JAN; MATTIASSON, 1998). Por outro lado, a aclimatação da biomassa metanogênica foi obtida dentro de até 3 dias de operação do sistema sob o pH em questão, com recuperação da produção de metano, a qual chegou a $98 \%(\mathrm{pH}=6,5), 91 \%(\mathrm{pH}=6,0), 77 \%(\mathrm{pH}=5,5)$ e $67 \%$ ( $\mathrm{pH}=5,0)$ da produção original $(\mathrm{pH}=7,0)($ JAN; MATTIASSON, 1998). 
Dessa forma, vale notar que, ainda que a atividade das AM tenha sido prejudicada, os valores de $\mathrm{pH}$ no meio reacional estiveram dentro de uma faixa viável para a metanogênese ao longo de todas as fases operacionais, evitando-se o colapso do sistema pela inibição total da metanogênese. Ao longo da ETAPA 3 o valor mínimo de $\mathrm{pH}$ medido no interior do reator foi de 6,4, enquanto o máximo valor de $\mathrm{pH}$ interno foi de 7,5. Conforme mostrado pelos perfis espaciais de $\mathrm{pH}$ realizados ao final de 4 fases operacionais da ETAPA 3 (Figura 5.40), as condições de mistura no DFSBR, inerentes à produção e o deslocamento do biogás, também evitaram o estabelecimento de gradientes com variações bruscas de $\mathrm{pH}$ ao longo do leito reacional. Caso contrário, mesmo os organismos redutores de sulfato poderiam ter sido prejudicados, conforme observado por GIL-GARCIA et al. (2018).

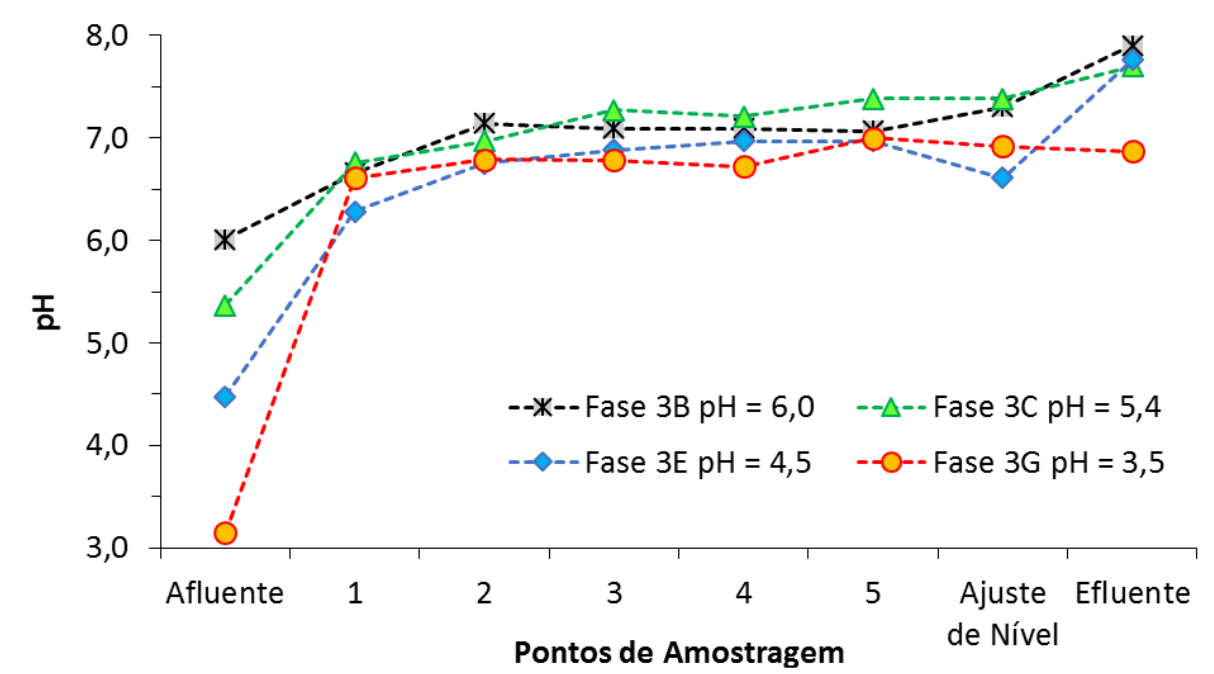

Figura 5.40: Perfis espaciais de $\mathrm{pH}$ ao longo do leito do reator DFSBR realizados ao final das FASES 3B, 3C, 3E e 3G.

Fonte: $\mathrm{O}$ autor.

Além do abaixamento do $\mathrm{pH}$ afluente, fator que esteve diretamente relacionado com a diminuição do pH no líquido interno do DFSBR, a diminuição da alcalinidade a bicarbonato disponível no meio líquido ao longo da ETAPA 3 também pode ter desempenhado uma função significativa na restrição da atividade dos microrganismos metanogênicos. 
O gráfico da Figura 5.41 permite visualizar a queda gradativa da alcalinidade total do efluente do sistema, submetido à diminuição do $\mathrm{pH}$ afluente.

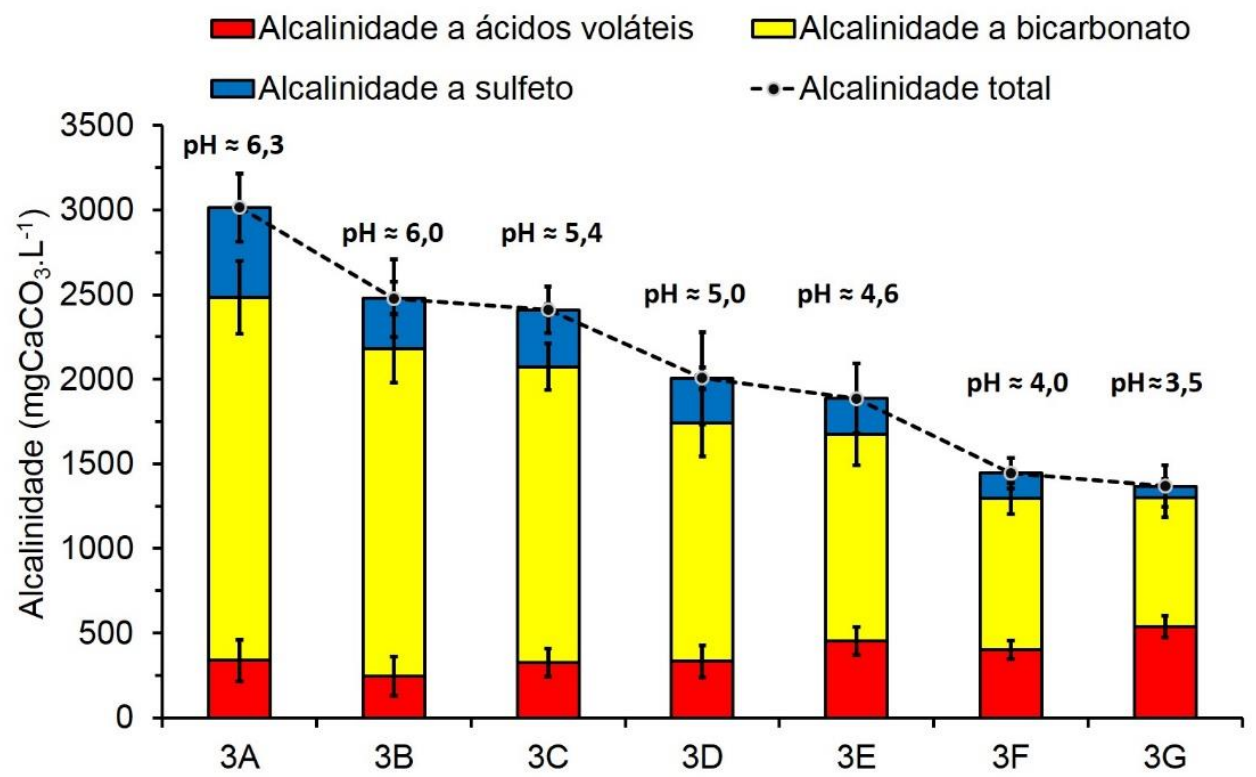

Figura 5.41. Características do efluente do DFSBR com relação às frações de alcalinidade total devidas a sulfeto, a bicarbonato e a ácidos voláteis durante a ETAPA 3. As barras de erros representam o desvio-padrão.

Fonte: $\mathrm{O}$ autor.

Esse resultado pode ser explicado pela maior demanda por alcalinidade para neutralização do meio líquido interno do reator quando submetido aos menores valores de $\mathrm{pH}$ afluente. A alcalinidade a bicarbonato, produzida pelo processo anaeróbio, especialmente pelas reações de redução de sulfato (Equação (3.5)), foi consumida pelo aumento da acidez total do afluente, resultando no deslocamento do equilíbrio químico do $\mathrm{HCO}_{3}{ }^{-}$para $\mathrm{CO}_{2}$, como já mencionado anteriormente (Tabela 5.14). Dessa forma, a alcalinidade devida ao bicarbonato no efluente do DFSBR passou de cerca de $2000 \mathrm{mgCaCO}_{3} \cdot \mathrm{L}^{-1}$ durante as FASES 3A e $3 \mathrm{~B}\left(\mathrm{pH}\right.$ AFLUENTE $\approx 6,3$ e 6,0 , respectivamente), para próximo de $1500 \mathrm{mgCaCO}_{3} \cdot \mathrm{L}^{-1}$ durante as FASES 3C, 3D e 3E (pH AFLUENTE $\approx 5,4,5,0$ e 4,6, respectivamente). Durante as FASES $3 \mathrm{~F}$ e $3 \mathrm{G}(\mathrm{pH}$ AFLUENTE $\approx 4,0$ e 3,5, respectivamente), por sua vez, foram observados valores próximos a $800 \mathrm{mgCaCO} 3 \cdot \mathrm{L}^{-1}$. 
A diminuição no conteúdo de alcalinidade no DFSBR implicou no desbalanceamento do processo anaeróbio, principalmente durante a última fase da ETAPA 3. Essa afirmação decorre da observação da relação Ai/Ap, a qual representa o equilíbrio entre a geração de ácidos orgânicos $(\mathrm{Ai}=$ alcalinidade intermediária $)$ e alcalinidade a bicarbonato $(\mathrm{Ap}=$ alcalinidade parcial) no sistema. Segundo RIPLEY et al. (1986), um reator anaeróbio equilibrado corresponde a uma relação Ai/Ap da ordem de 0,30. Quanto maior essa relação, maior a instabilidade na digestão anaeróbia. O gráfico da Figura 5.42 mostra a relação Ai/Ap no DFSBR ao longo do tempo.

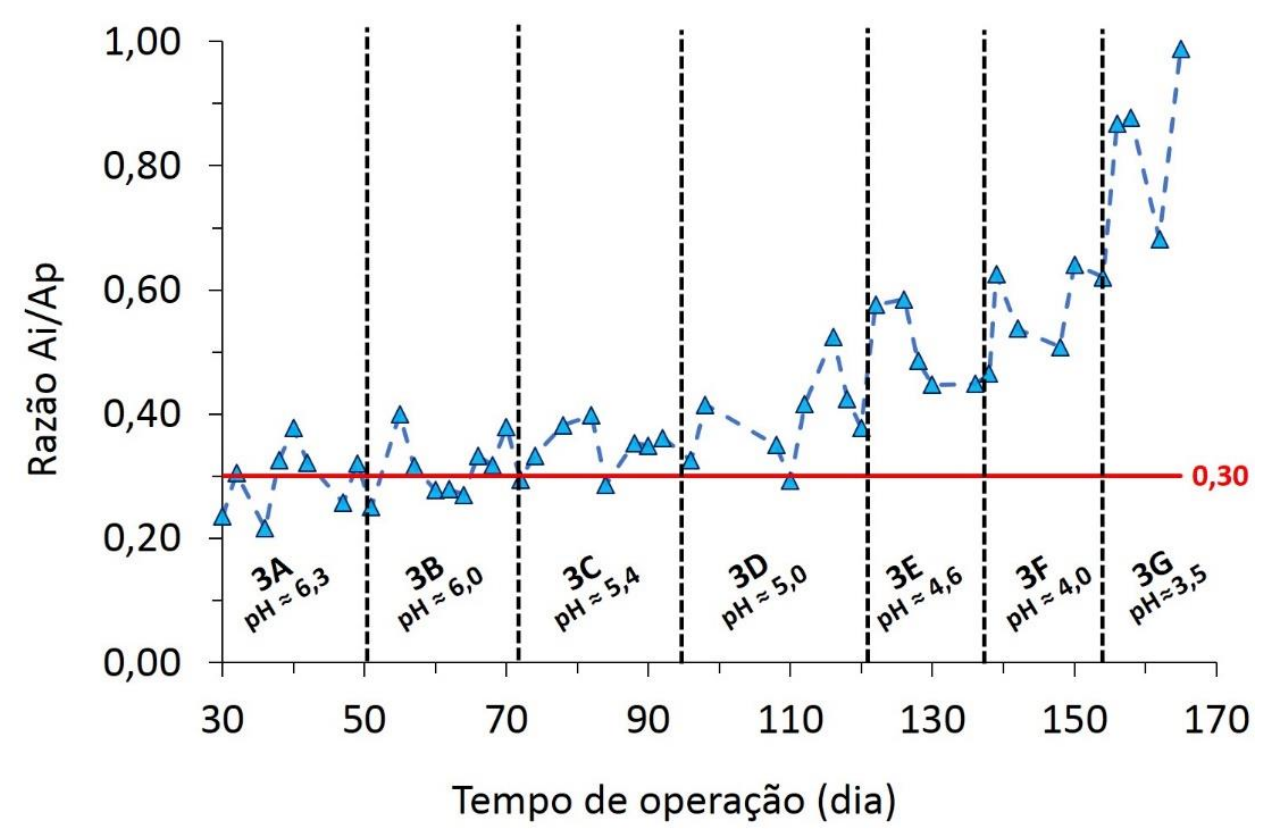

Figura 5.42. Monitoramento da relação Ai/Ap ao longo do tempo operacional da ETAPA 3. Fonte: $\mathrm{O}$ autor.

De fato, durante as FASES 3A a 3C, as relações Ai/Ap no DFSBR permaneceram próximas do valor de referência $(0,30)$, variando de 0,22 a 0,43. Já durante as FASES 3E e 3F essa relação foi de 0,45 a 0,64. Na FASE 3G, por fim, a relação Ai/Ap variou de 0,70 a 0,98, 
indicando o forte desequilíbrio na digestão anaeróbia, pela alta fração de ácidos voláteis diante da menor parcela de alcalinidade disponível.

Embora a relação Ai/Ap seja também uma característica da água residuária a ser tratada, podendo variar a relação ótima dependendo das particularidades do sistema de tratamento, devendo ser verificado caso a caso, esse valor permanece uma referência importante para o monitoramento imediato de reatores anaeróbios (FORESTI, 1994), principalmente quando a geração de metano é desejada.

Como era de se esperar, devido à queda na participação da metanogênese no processo de remoção de DQO, maiores concentrações residuais de ácido acético no efluente foram observadas (Figura 5.43), as quais passaram de $330 \pm 110 \mathrm{mgDQO} . \mathrm{L}^{-1}$ durante as FASES 3A a 3D, para $460 \pm 90 \mathrm{mgDQO} . \mathrm{L}^{-1}$ durante as FASES 3E a 3F, atingindo a média de $570 \pm 70$ mgDQO. $\mathrm{L}^{-1}$ durante a FASE 3G. Esses resultados indicaram que a metanogênese acetoclástica foi afetada pela diminuição da alcalinidade do sistema.

Vale ressaltar que, embora tenham aumentado, as concentrações de ácido acético no efluente do DFSBR não atingiram níveis considerados tóxicos para os microrganismos, os quais se situam em faixas acima dos 800 mg.L -1 $^{-1}$ HILL; COBB; BOLTE, 1987), já tendo sido reportada a capacidade dos organismos metanogênicos suportarem concentrações de até 2400 mg.L $\mathrm{L}^{-1}$ desse ácido orgânico em particular (WANG et al., 2009).

Por outro lado, a conversão de DQO a ácidos orgânicos voláteis também foi prejudicada, levando aos altos valores de DQO remanescente (> $\left.1.000 \mathrm{mg} . \mathrm{L}^{-1}\right)$ medidos no efluente do reator durante as FASES 3E a 3G (Figura 5.43), nas quais foram obtidas as menores eficiências de remoção de DQO (Figura 5.37.a) associadas às menores produções de metano (Figura 5.39). 


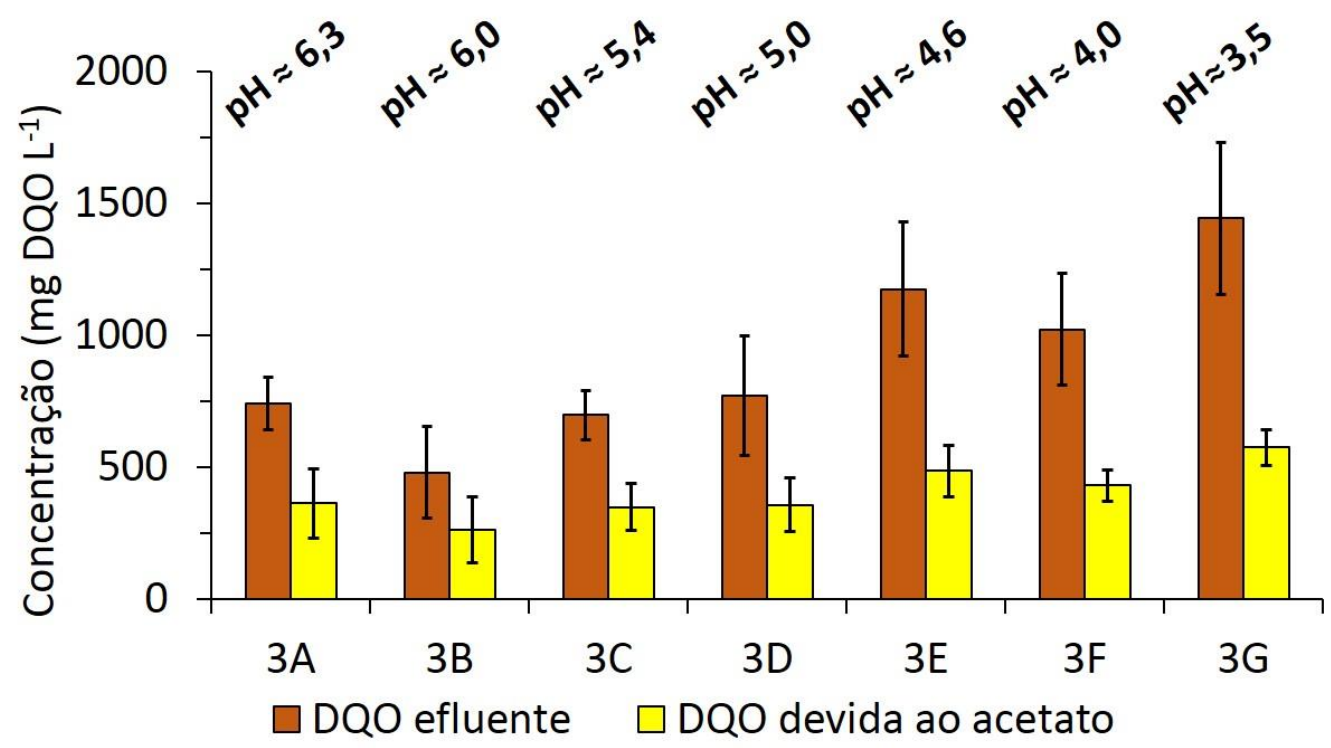

Figura 5.43. Concentrações de ácido acético (em termos de DQO) no efluente do reator DFSBR durante as fases operacionais da ETAPA 3. As barras de erro representam o desvio-padrão.

Fonte: $\mathrm{O}$ autor.

Embora as BRS sejam capazes de competir mais facilmente pelo hidrogênio produzido nas etapas iniciais da digestão anaeróbia do que os organismos metanogênicos (STAMS et al., 2005; LOVLEY et al., 1982), a presença de AM hidrogenotróficas no DFSBR, ainda que de forma marginal, não pode ser descartada. Uma vez que as reações envolvidas na conversão de hidrogênio a metano são dependentes do íon bicarbonato (Equação (5.4)), o qual atua como aceptor de elétrons (DELGADO et al., 2012; MUYZER; STAMS, 2008), a diminuição na alcalinidade disponível no meio líquido também prejudicaria a atividade hidrogenotrófica dos microrganismos metanogênicos.

$$
\begin{aligned}
& \mathrm{HCO}_{3}{ }^{-}+4 \mathrm{H}_{2}+\mathrm{H}^{+} \rightarrow \mathrm{CH}_{4}+3 \mathrm{H}_{2} \mathrm{O} \\
& \Delta \mathrm{G}^{\mathbf{o}}=-135,6 \mathrm{~kJ} / \text { reação }
\end{aligned}
$$

No presente caso, o aumento da pressão parcial do hidrogênio no sistema por inibição da atividade de AM ligadas ao consumo de hidrogênio no reator seria indicado pelo aumento 
da concentração de ácido propiônico, anteriormente ausente do efluente do DSFBR (ETAPAS 1 e 2). De fato, concentrações residuais desse ácido orgânico foram detectadas durante as FASES 3F (20 mgDQO.L $\left.\mathrm{L}^{-1}\right)$ e $3 \mathrm{G}\left(15 \mathrm{mgDQO} . \mathrm{L}^{-1}\right)$.

Uma desvantagem desse resultado deve-se à necessidade de uma etapa de póstratamento do efluente do DFSBR tratando DAM em conjunto com vinhaça real sem neutralização do $\mathrm{pH}$ afluente, devido à piora na qualidade do efluente do reator observada durante a ETAPA 3. Por outro lado, a diminuição da dosagem de vinhaça para o tratamento da DAM sintética resultaria em menor carga orgânica aplicada, concomitantemente à redução da relação $\mathrm{DQO} / \mathrm{SO}_{4}{ }^{2-}$. A maior pressão de seleção favorável para a predominância da sulfetogênese no processo de remoção da matéria orgânica poderia, então, resultar no aumento da eficiência de remoção de DQO pelo sistema (VIEIRA et al., 2016). Uma menor carga orgânica também poderia resultar em menores concentrações de ácidos orgânicos gerados, com recuperação do balanceamento da relação Ai/Ap. Essa hipótese, todavia, não pode ser testada durante o presente estudo, permanecendo como um importante item a ser investigado em trabalhos futuros.

\subsubsection{Efeito do pH interno sob as espécies de sulfeto dissolvido no DFSBR}

Como observado anteriormente no gráfico da Figura 5.41, a fração de alcalinidade devida ao sulfeto dissolvido, além de ter sido removida parcialmente pela precipitação do sulfeto por precipitação após a introdução da DAM sintética, também pode ter sido consumida pela diminuição do pH afluente. Isso já era esperado em função do comportamento do íon $\mathrm{HS}^{-}$, o qual atua como um ácido fraco em solução, tamponando o meio líquido pela retirada de íons $\mathrm{H}^{+}$(Equação (3.14)). Como consequência, há ocorrência do aumento da proporção de sulfeto dissolvido na forma molecular $\left(\mathrm{H}_{2} \mathrm{~S}\right)$, a qual é usualmente apontada como causadora de maior toxicidade sobre as arqueias metanogênicas (MCCARTNEY e 
OLESZKIEWICZ, 1993). Essa poderia ser apontada como outra possível razão para a queda da atividade metanogênica no sistema. De fato, o $\mathrm{H}_{2} \mathrm{~S}$ molecular é capaz de permear mais facilmente pela membrana plasmática dos microrganismos, afetando negativamente o metabolismo celular (KOSCHORRECK, 2008).

Todavia, como pode ser observado na Figura 5.44, apesar da concentração de sulfeto molecular dissolvido $\left(\mathrm{H}_{2} \mathrm{~S}\right)$ durante a ETAPA 3 ter variado com a diminuição do $\mathrm{pH}$ afluente das FASES 3B a 3G, passando de cerca de $110 \mathrm{mg} . \mathrm{L}^{-1}$ para cerca de $160 \mathrm{mg} . \mathrm{L}^{-1}$, essas concentrações foram sempre menores que as alcançadas durante a FASE 3A. Durante essa fase inicial de adaptação do reator, com pH afluente acima de 6,30, as concentrações de sulfeto total dissolvido e a fração de sulfeto molecular foram da ordem de $580 \mathrm{mg} . \mathrm{L}^{-1}$ e 250 mg. $\mathrm{L}^{-1}$, respectivamente. Nessa fase, apesar do DFSBR ter atingido valores de STD e $\mathrm{H}_{2} \mathrm{~S}$ superiores aos limites máximos indicados pela literatura (MAILLACHERUVU et al., 1993; KOSTER et al., 1986) não foi notada inibição da metanogênese (Figura 5.38 e Figura 5.39).

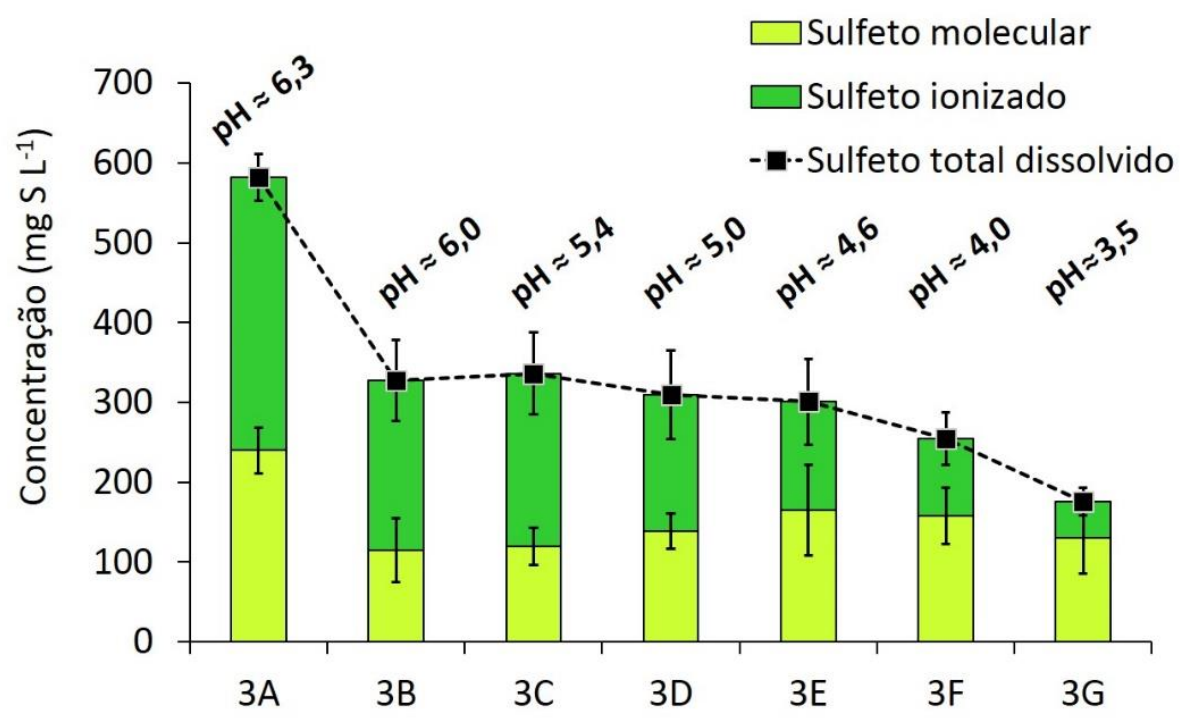

Figura 5.44. Concentrações de sulfeto total dissolvido, sulfeto de hidrogênio molecular $\left(\mathrm{H}_{2} \mathrm{~S}\right)$ e sulfeto ionizado $\left(\mathrm{HS}^{-}\right)$no efluente do reator DFSBR durante a ETAPA 3. As barras de erros representam o desvio-padrão.

Fonte: $\mathrm{O}$ autor. 
Desse resultado pode-se concluir que a adaptação do consórcio microbiano às condições sulfetogênicas estabelecidas no DFSBR durante a ETAPA 3 foi realizada com sucesso, não podendo ser atribuído ao sulfeto dissolvido a causa de inibição parcial da metanogênese durante as últimas fases, operadas com pH afluente ácido.

\subsubsection{Influência do abaixamento do $\mathrm{pH}$ sobre a precipitação de sulfetos de ferro no DFSBR}

Ao longo das fases operacionais da ETAPA 3 foram obtidas eficiências de remoção de ferro variando de $90 \%$ a 98\% (Figura 5.45). A frequência de descarte do material precipitado, realizado a cada 3 dias de operação (100 mL de material sedimentado por vez), proporcionou a manutenção das altas eficiências de remoção de ferro observadas, com estabilidade nessa remoção. Falhas pontuais no descarte do material sedimentado resultaram em quedas temporárias nas eficiências de remoção e ferro em alguns dias das FASES 3B e 3G, o que foi prontamente solucionado.

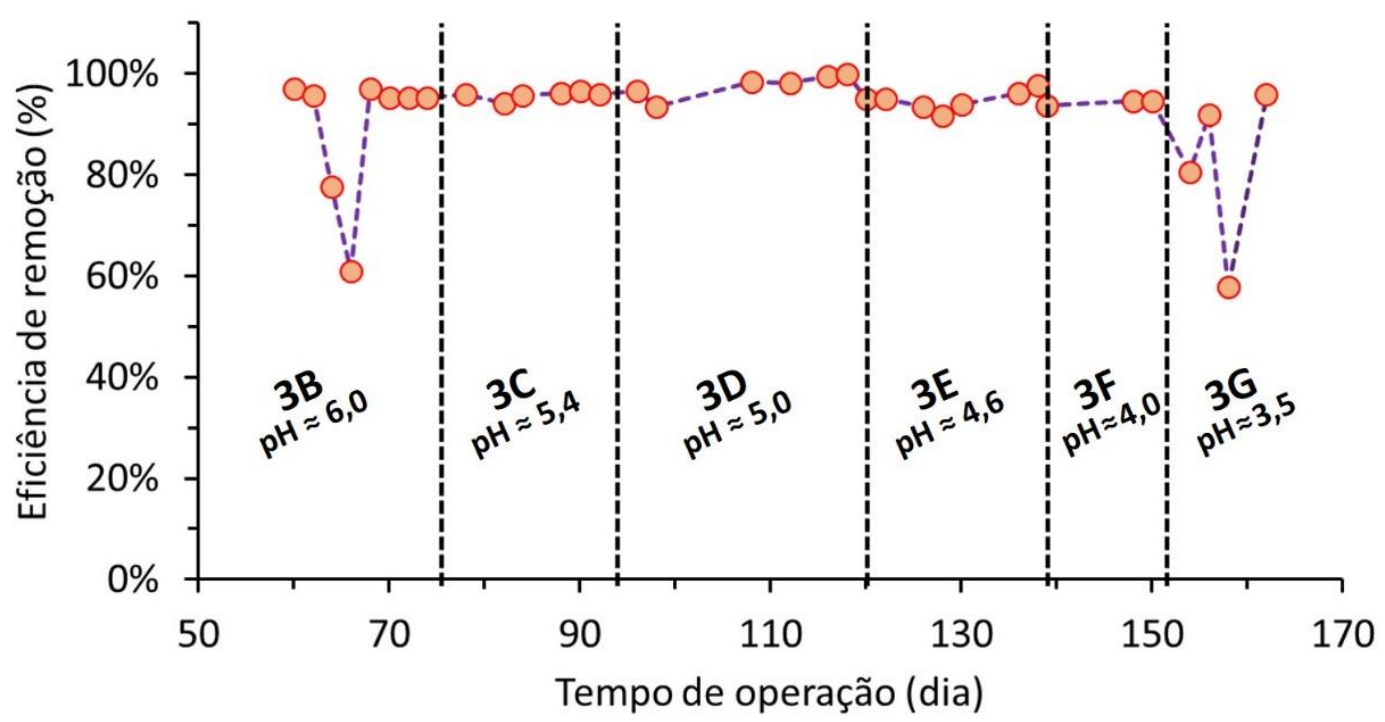

Figura 5.45. Monitoramento temporal das eficiências de remoção de ferro ao longo da ETAPA 3. Fonte: $\mathrm{O}$ autor. 
O valor médio de carga volumétrica de ferro aplicada ao longo da ETAPA 3 foi de $0,30 \pm 0,05 \mathrm{gFe}^{2+} \cdot \mathrm{L}^{-1} \cdot \mathrm{d}^{-1}$, enquanto a carga removida foi de $0,28 \pm 0,05 \mathrm{~g} \cdot \mathrm{L}^{-1} \cdot \mathrm{d}^{-1}$. A Tabela 5.15 resume o desempenho do DFSBR em cada fase operacional da ETAPA 3, na qual foram observadas as maiores eficiências de remoção de ferro no DFSBR.

Tabela 5.15. Cargas volumétricas de ferro aplicadas (CFVa) e removidas (CFVr), e eficiências de remoção de ferro total (ER-Fe) durante a ETAPA 3.

\begin{tabular}{|c|c|c|c|}
\hline \multirow{2}{*}{ FASES } & CFVa & CFVr & ER-Fe \\
\hline & \multicolumn{2}{|c|}{$\left(\mathrm{gFe}^{2+} \cdot \mathrm{L}^{-1} \cdot \mathrm{d}^{-1}\right)$} & $(\%)$ \\
\hline $\mathbf{3 A}$ * & $<0,002$ & & \\
\hline 3B & $0,27 \pm 0,02$ & $0,24 \pm 0,04$ & $93 \pm 7 * *$ \\
\hline $3 C$ & $0,27 \pm 0,01$ & $0,26 \pm 0,01$ & $96 \pm 1$ \\
\hline 3D & $0,35 \pm 0,03$ & $0,34 \pm 0,04$ & $97 \pm 3$ \\
\hline $3 E$ & $0,32 \pm 0,02$ & $0,31 \pm 0,02$ & $95 \pm 2$ \\
\hline $3 F$ & $0,30 \pm 0,01$ & $0,27 \pm 0,02$ & $95 \pm 1$ \\
\hline $3 G$ & $0,34 \pm 0,01$ & $0,28 \pm 0,07$ & $94 \pm 3^{* *}$ \\
\hline
\end{tabular}

*Durante a FASE 3A não foi realizado o monitoramento da remoção de ferro, visto que esse metal foi adicionado em concentrações traço, exclusivamente como nutriente para a biomassa.

**Para efeito de cálculo do valor médio e desvio-padrão foram desconsiderados os pontos em que houve falha no descarte do precipitado.

Fonte: O autor.

Os resultados reforçaram o potencial do DFSBR aplicado à precipitação de metais uma vez que o seu desempenho não foi prejudicado pela supressão da dosagem de $\mathrm{NaOH}$ e manutenção do $\mathrm{pH}$ afluente mais próximo do observado em DAM reais.

Os balanços das frações de enxofre na forma de sulfeto no DFSBR durante a Etapa 3 estão apresentados na Figura 5.46. Observou-se que, após a introdução da DAM sintética (FASE 3B em diante) uma parcela do sulfeto teoricamente gerado pela redução do sulfato removido não foi computado na fase líquida, o que foi atribuído à precipitação do sulfeto complexado com o ferro oriundo da DAM. 
Os escapes de sulfetos em suspensão foram notados principalmente durante a FASE 3B, tendo sido causados por falhas na frequência dos descartes do material precipitado, como já discutido anteriormente. No entanto, apesar da identificação de frações de sulfeto em suspensão, eventualmente presentes no efluente do reator, a remoção do ferro não foi comprometida (Figura 5.45).

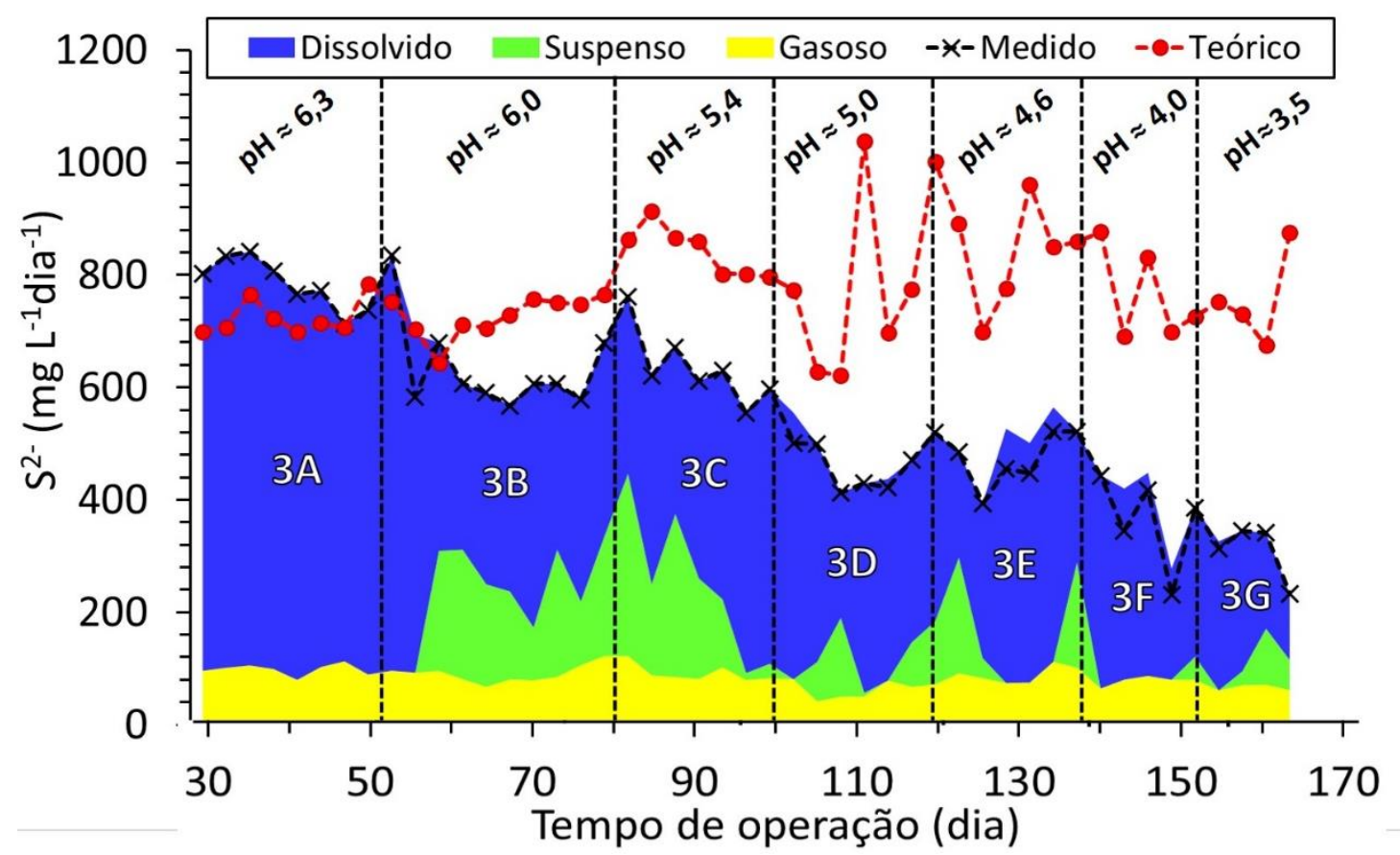

Figura 5.46: Frações de sulfeto produzidas pelo reator DFSBR ao longo da ETAPA 3.

Fonte: $\mathrm{O}$ autor.

Vale notar que, apesar da manutenção da carga de ferro aplicada durante toda a Etapa $3\left(0,30 \pm 0,05 \mathrm{gFe}^{2+} \cdot \mathrm{L}^{-1} \cdot \mathrm{d}^{-1}\right)$, a fração de sulfeto dissolvido medida no efluente do reator decresceu, acompanhando a diminuição do $\mathrm{pH}$ afluente e a queda da alcalinidade disponível no sistema (Figura 5.41). Esse comportamento pode ser atribuído à maior volatilização do sulfeto de hidrogênio em solução, de forma que escapes de sulfeto durante a manipulação das amostras do efluente podem ter prejudicado a quantificação de uma parcela desse componente. 
Outra explicação para esse fenômeno é a de que, com a diminuição no valor do pH no meio líquido interno do reator, o qual passou de 7,5 para 6,4 após a supressão da dosagem de $\mathrm{NaOH}$, a fração de ferro precipitada como carbonato decresce, favorecendo uma maior predominância dos sulfetos de ferro precipitados (MOSEY, 1971). De fato, MOSEY e HUGHES (1975) já demonstraram que o pH rege o mecanismo de precipitação de metais na presença de sulfetos e carbonatos. Enquanto que para as condições de $\mathrm{pH}$ da faixa neutra à alcalina a precipitação de metais na forma de carbonatos pode ser favorecida, em valores de pH mais baixos a contribuição dos íons carbonatos torna-se insignificante. Assim, nas fases operadas com menores valores de $\mathrm{pH}$ a formação de sulfetos insolúveis aparentou predominar, levado ao aumento da remoção de sulfeto da fase líquida (Figura 5.46).

As determinações gravimétricas do material precipitado, coletado no cone inferior do DFSBR, indicaram um aumento na proporção de sólidos suspensos fixos (Figura 5.47.a), o que se correlaciona com a maior precipitação dos sulfetos de ferro nas condições de menor pH da fase líquida. As análises de EDX efetuadas no material precipitado após calcinação a $\left(550^{\circ} \mathrm{C}\right)$, por sua vez, indicaram a proporção da ordem de $42 \%$ de ferro durante as FASES 3B e 3C, tendo essa proporção aumentado para cerca de 57\% durante as FASES 3D a 3G (Figura 5.47.b), confirmando o favorecimento da precipitação de ferro sob menores valores de $\mathrm{pH}$ da fase líquida.

Esses resultados confirmaram a viabilidade de aplicação do reator DFSBR para o tratamento de DAM visando à precipitação de metais, especialmente em condições de pH ácido, o que possibilitaria a operação do sistema sem custos associados com a dosagem de agentes alcalinizantes, uma das desvantagens dos processos químicos convencionais de precipitação de metais. 
(a)

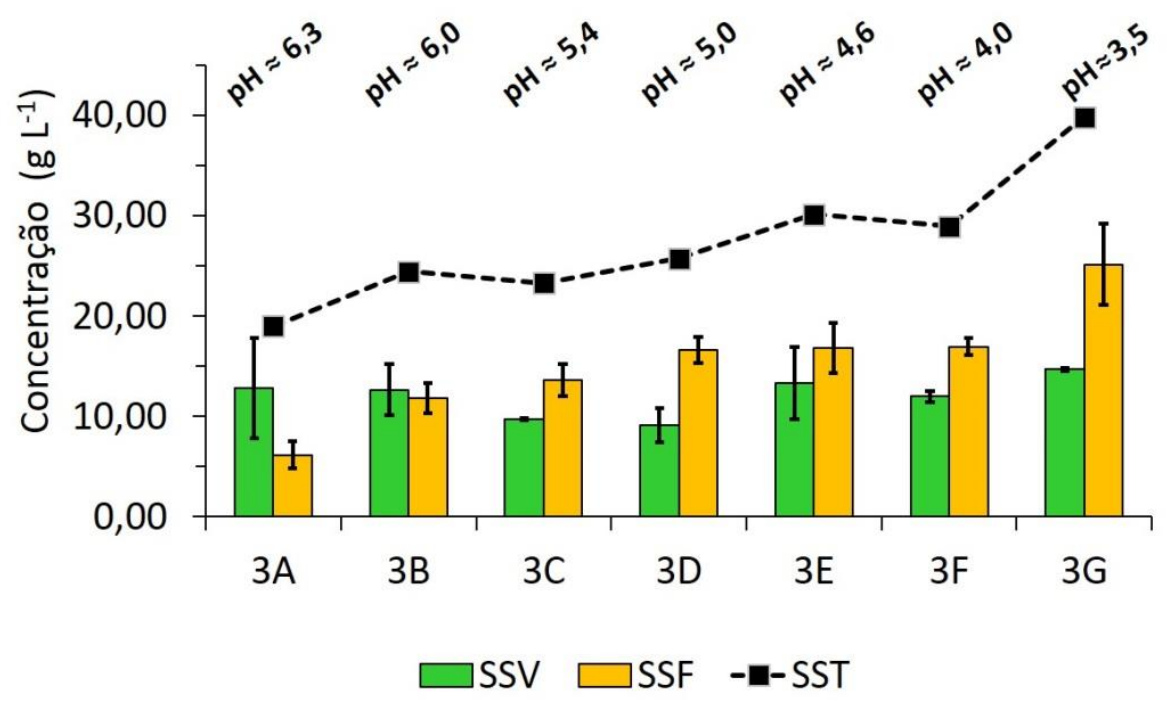

(b)

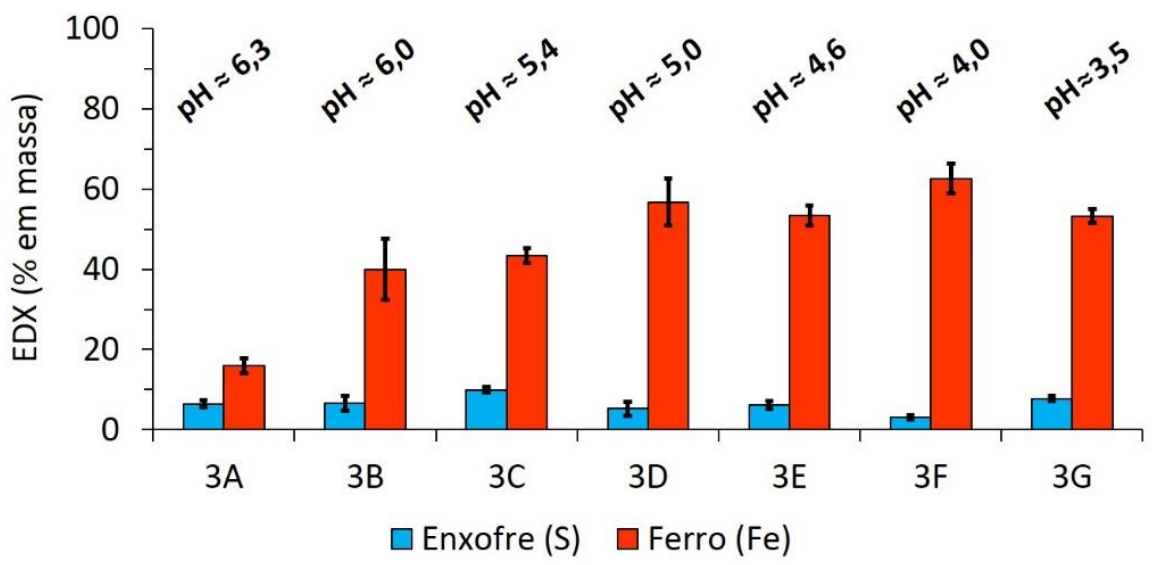

Figura 5.47. Análise do material precipitado: (a) Concentrações de sólidos totais, fixos e voláteis nas amostras de descarte em cada fase da ETAPA 3; e (b) Caracterização elementar por EDX das cinzas do material coletado. As barras de erro representam o desvio-padrão.

Fonte: $\mathrm{O}$ autor.

Além de fero e enxofre, outros elementos foram identificados no material sedimentado em diferentes proporções, tais como cálcio, fósforo, magnésio e sódio (até 5\% em massa), e potássio (até $10 \%$ em massa), os quais são derivados da vinhaça utilizada.

\subsubsection{Caracterização da diversidade microbiana-ETAPA 3}

Para avaliação da diversidade populacional obtida ao longo da ETAPA 3, amostras dos inóculos (IN-1 e IN-2) e de biomassa coletada ao final de 4 diferentes fases operacionais 
(FASES 3A, 3B, 3E e 3G) foram analisadas pela técnica de PCR-DGGE. Na Figura 5.48 são apresentados os dendrogramas construídos a partir dos padrões de bandas do DGGE para os Domínios Archaea (a) e Bacteria (b). As 4 amostras do DFSBR foram escolhidas para representar as modificações ocorridas na diversidade microbiana do biofilme ao longo da ETAPA 3: ao início da operação com vinhaça real e na ausência de DAM sintética (FASE 3A); imediatamente após a introdução da DAM rica em ferro (FASE 3B); após o abaixamento do pH afluente para 4,6 (FASE 3E); e ao final da operação (170 dias), durante a FASE 3G, mantida com pH afluente próximo de 3,5.

Para o Domínio Archaea, similaridade da ordem de $81 \%$ entre os inóculos IN-1 e IN2 sugerem que ambos os lodos anaeróbios podem ter contribuído de forma semelhante para o estabelecimento das populações de AM no DFSBR ao longo da ETAPA 3. Com relação às amostras de biomassa colhidas do reator, as FASES 3A e 3B apresentaram $82 \%$ de similaridade entre si, enquanto que as FASES 3E e 3G apresentaram similaridade de $96 \%$. Já a similaridade entre as FASES 3A e 3B agrupadas com relação às FASES 3E e 3G em conjunto foi de $69 \%$, sugerindo mudanças sofridas pelo biofilme com o decorrer da operação do DFSBR durante a ETAPA 3. 
(a) Domínio Archaea
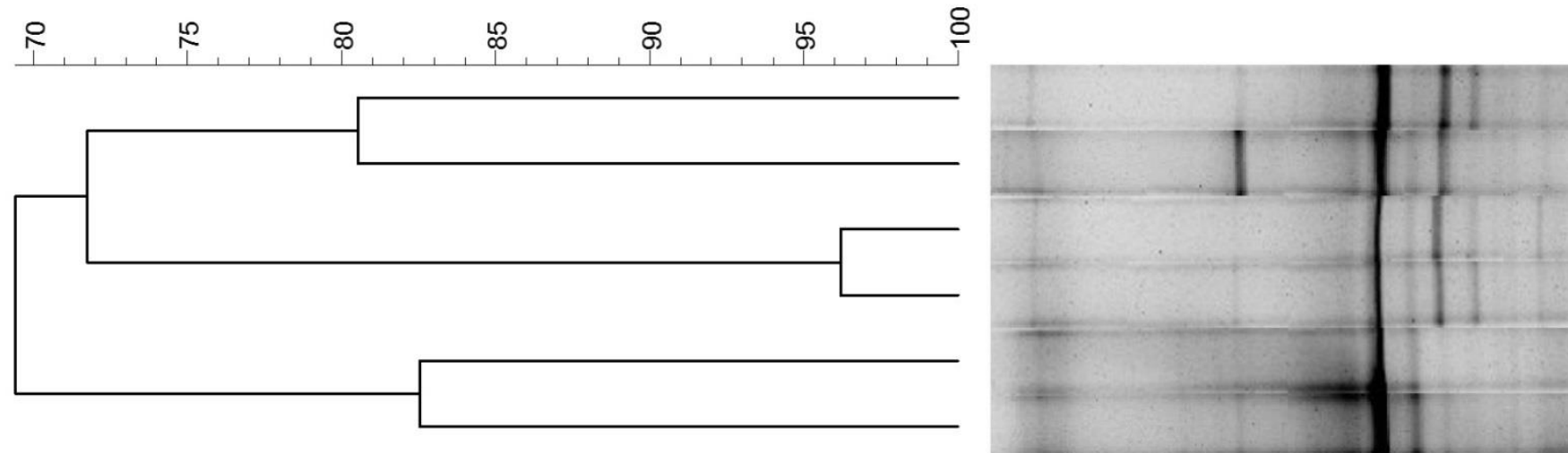

IN-2

IN-1

FASE 3G

FASE 3E

FASE 3B

FASE 3A

(b) Domínio Bacteria

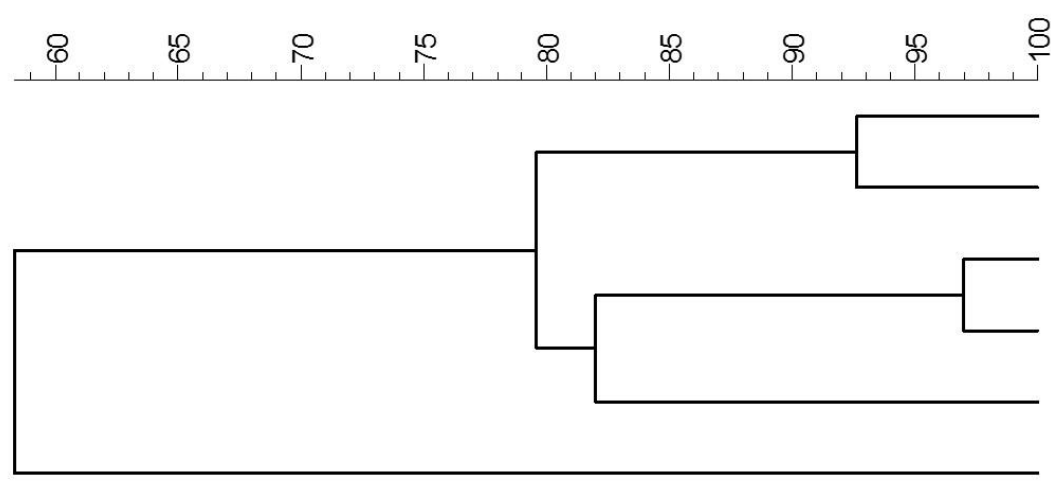

음

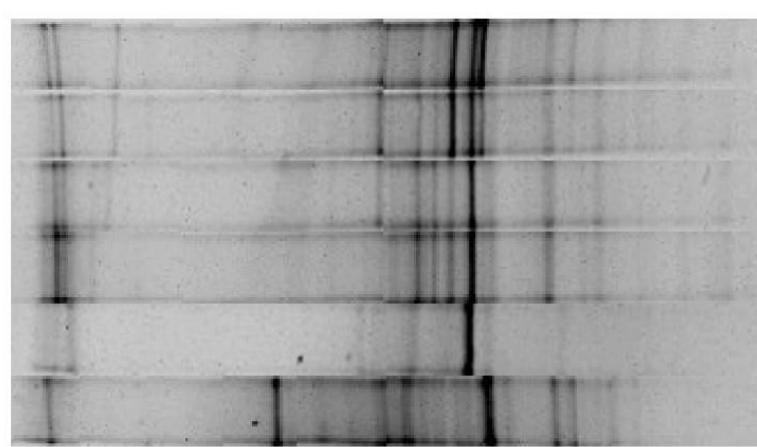

FASE 3G

FASE 3E

FASE 3B

FASE 3A

IN-2

IN-1

Figura 5.48: Dendrogramas baseados no coeficiente de similaridade de Pearson a partir do padrão de bandas do DGGE encontrado nos inóculos (IN1 e IN-2) e em amostras de biomassa coletadas ao final das FASES 3A, 3B, 3E e 3G para os Domínios Archaea (a) e Bacteria (b).

Fonte: $\mathrm{O}$ autor 
Uma vez que durante as FASES 3A e 3B o reator foi mantido em condições próximas da neutralidade $\left(\mathrm{pH}_{\text {INTERNO }} \approx 7,2\right.$ e 7,3 , respectivamente), as condições mais ácidas do sistema durante as FASES $3 E$ e $3 \mathrm{G}\left(\mathrm{pH}_{\mathrm{INTERNO}} \approx 6,9\right.$ e 6,5, respectivamente) podem ter implicado na modificação da diversidade de arqueias observada no DFSBR (Figura 5.48).

De fato, o monitoramento do desempenho do DFSBR ao longo da ETAPA 3 indicou a sensibilidade das AM ao aumento da acidez do meio líquido, com queda na sua participação no processo global de remoção de matéria orgânica (Figura 5.38) associada à diminuição na produção de metano (Figura 5.39). Além disso, certas bandas visualizadas nos padrões do DGGE dos inóculos, e não aparentes no DGGE das FASES 3A e 3B, puderam ser novamente visualizadas no padrão do DGGE das FASES 3E e 3G (Figura 5.48.a), sugerindo o reestabelecimento de alguns grupos de arqueias favorecidos pelas condições mais ácidas do sistema.

Analisando os padrões das bandas do DGGE efetuado para o Domínio Bacteria (Figura 5.48.b) observou-se uma menor similaridade entre as populações presentes no inóculo IN-1 e todas as outras amostras (58\%), diferentemente do obtido para o DGGE do Domínio Archaea. Um maior número de bandas também pode ser notado na amostra IN-1 em relação à amostra IN-2, dado a alta especialização da população de bactérias oriundas do reator UASB processando vinhaça, do qual foi obtido o inóculo IN-2 (ALVES, 2018 - trabalho de doutorado em andamento) $)^{3}$. Já a maior riqueza populacional notada no inóculo IN-1 pode ser explicada pela alta gama de substratos orgânicos fornecida ao reator UASB dedicado ao tratamento de efluente de abatedouro de aves (SAKAMOTO et al., 2016; DEL NERY et al., 2007).

${ }^{3}$ ALVES, I. Estudo da manta de lodo e do efeito das taxas de recirculação e das cargas orgânicas em reatores UASB para produção de metano no processamento da vinhaça de cana-de-açúcar. Tese (Doutorado). Trabalho em andamento pelo Programa de Pós Graduação em Engenharia Hidráulica e Saneamento da Escola de Engenharia de São Carlos (EESC/USP). 
A maior similaridade entre o inóculo $\mathrm{IN}-2$ e as amostras do reator DFSBR, especialmente com relação às FASES 3A e 3B (82\%), explica-se pelo fato do reator DFSBR também ter sido submetido ao longo de toda a ETAPA 3 ao mesmo substrato orgânico (vinhaça de cana-de-açúcar) utilizado para alimentar o reator UASB no qual o IN-2 foi cultivado.

Por outro lado, a similaridade de $79 \%$ entre as amostras do inóculo IN-2 agrupado com as amostras das FASES 3A e 3B em relação às FASES 3E e 3G em conjunto, indicando modificações na estrutura populacional de bactérias do DFSBR entre o início e o final da operação, também pode ser atribuída à mudança das condições de pH do reator. Assim como anteriormente mencionado para o DGGE do Domínio Archaea, notou-se o aparecimento de bandas no padrão das amostras ao final das FASES 3E e 3G que não se mostraram visualmente presentes no DGGE das FASES 3A e 3B.

Para melhor investigação das modificações sofridas pela biomassa ao longo da ETAPA 3, associadas com a supressão da dosagem de álcali externo no reator, bem como para elucidar as populações de microrganismos envolvidos no sistema de tratamento da DAM sintética em co-digestão com vinhaça, procedeu-se o sequenciamento do RNAr 16S das amostras de biofilme coletas ao final das FASES 3A e 3G. Os resultados são apresentados no item a seguir.

\subsubsection{Caracterização da comunidade microbiana por sequenciamento do}

\section{RNAr 16S}

O gene 16S rDNA das amostras obtidas ao final da operação das FASES 3A e 3G foi amplificado e sequenciado na plataforma Illumina MiSeq.

Com coeficiente de similaridade de 97\%, foram obtidas 1.244 OTUs a partir da amostra da FASE 3A, sendo 110 singletons (OTUs com uma única sequência), e 1.287 OTUs 
a partir da amostra da FASE 3G, sendo 128 singletons. Após a remoção das singletons, restaram 1.134 e 1.159 OTUs nas amostras 3A e 3G, respectivamente (Tabela 5.16). As singletons foram removidas para fins de classificação taxonômica, mas levadas em conta para determinação dos índices de diversidade. Ao todo, foram obtidas 96.203 sequências provenientes da amostra 3A e 103.675 sequências provenientes da amostra 3G (Tabela 5.16).

Os índices ecológicos $\alpha$, mostrados na Tabela 5.16, indicaram que as comunidades microbianas obtidas ao final das FASES 3A e 3B foram relativamente semelhantes em termos de riqueza (Chao1) e de diversidade (Shannon).

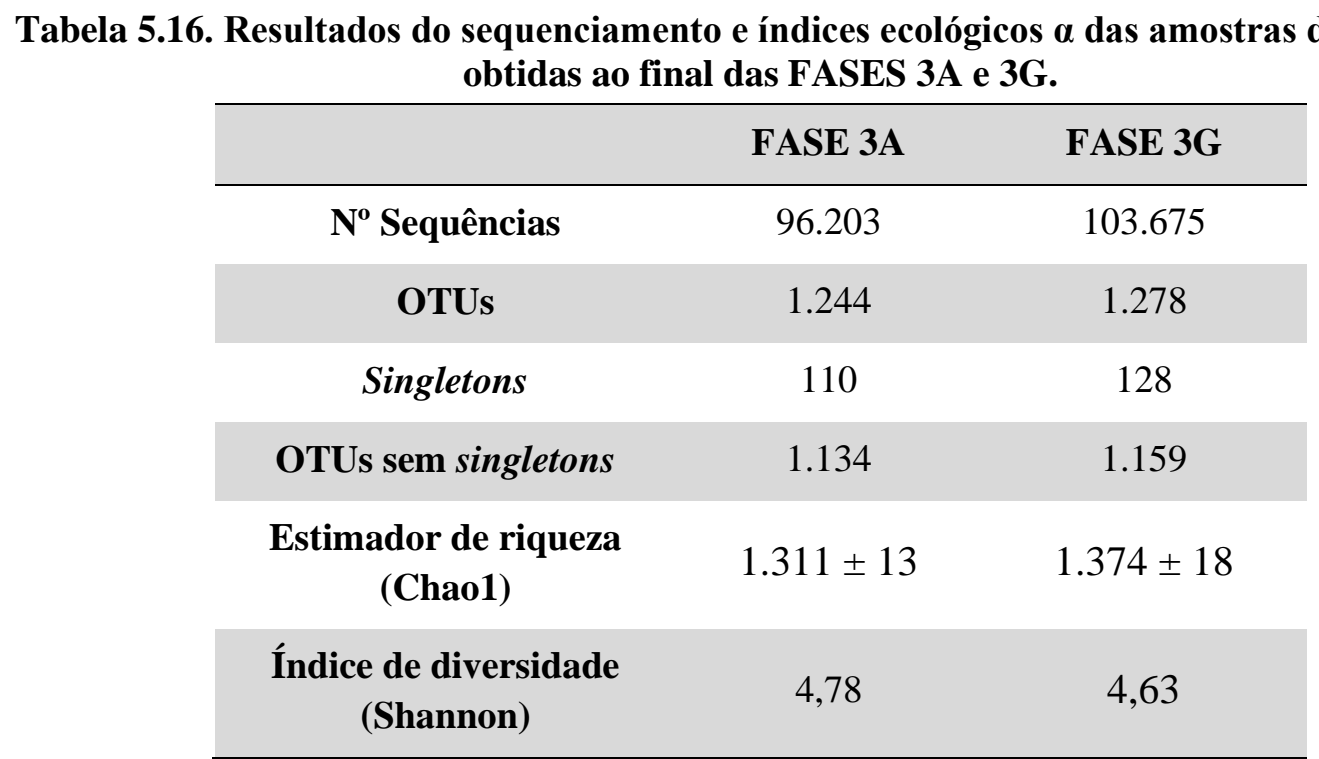

Fonte: O autor.

As curvas de rarefação obtidas a partir das duas amostras (Figura 5.49.a), com nível de similaridade de $97 \%$, apresentaram a formação de platôs, tanto para os níveis taxonômicos de família quanto de gênero, indicando que o esforço amostral foi adequado para caracterizar completamente a riqueza da comunidade microbiana das amostras. As curvas de rarefação em separado também confirmaram uma amostragem representativa das riquezas referentes aos Domínios Archaea e Bacteria, aos níveis de família e gênero (Figura 5.49.b e Figura 5.49.c, respectivamente). 
a)
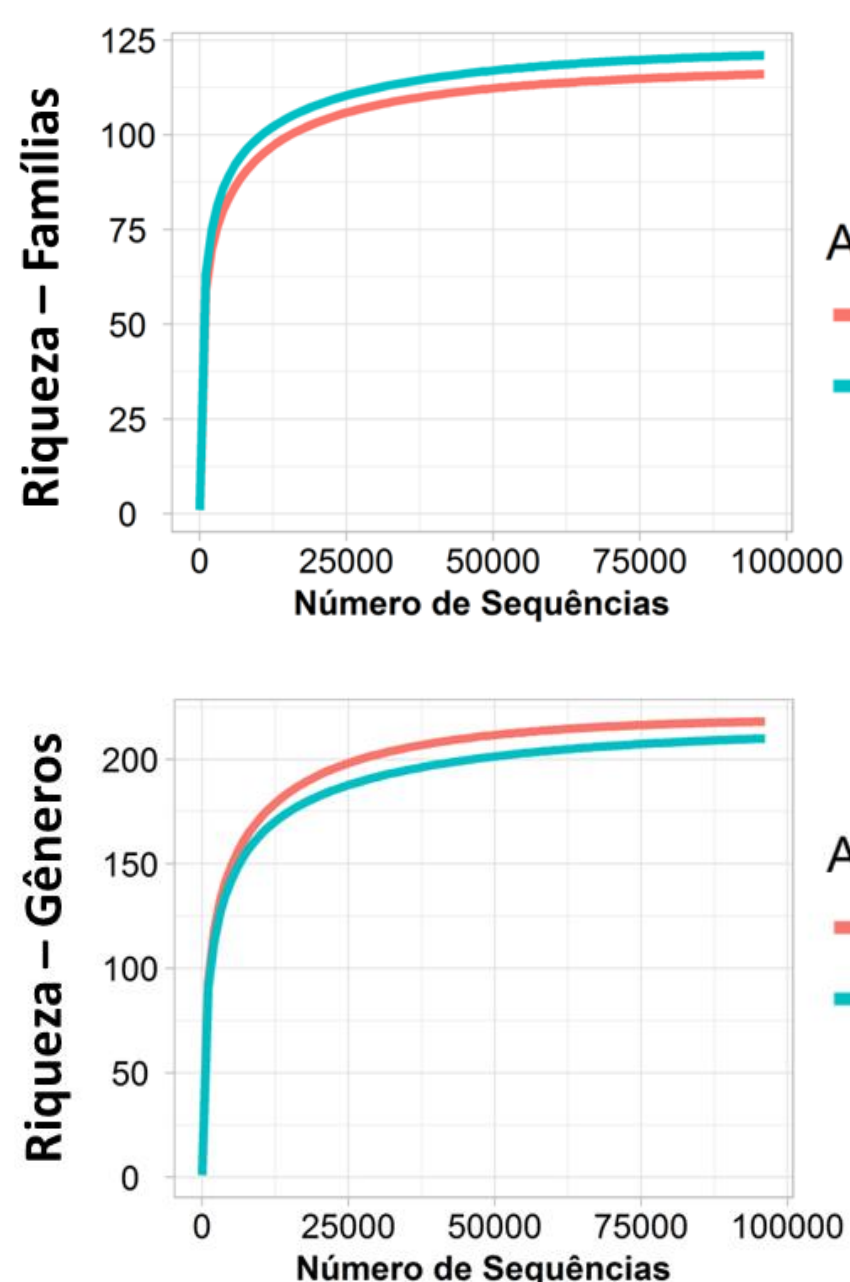

b)

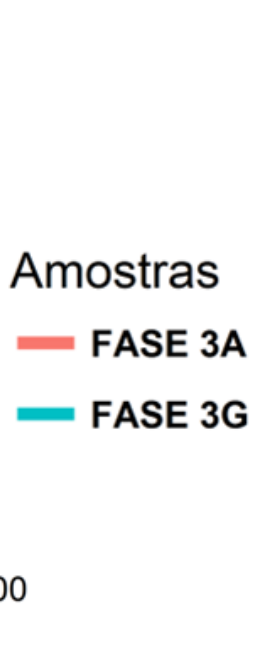

Amostras

- FASE 3A

- FASE $3 G$

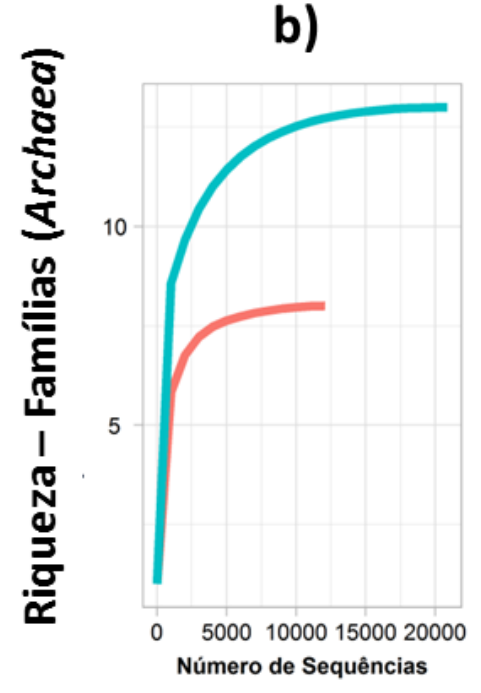

c)
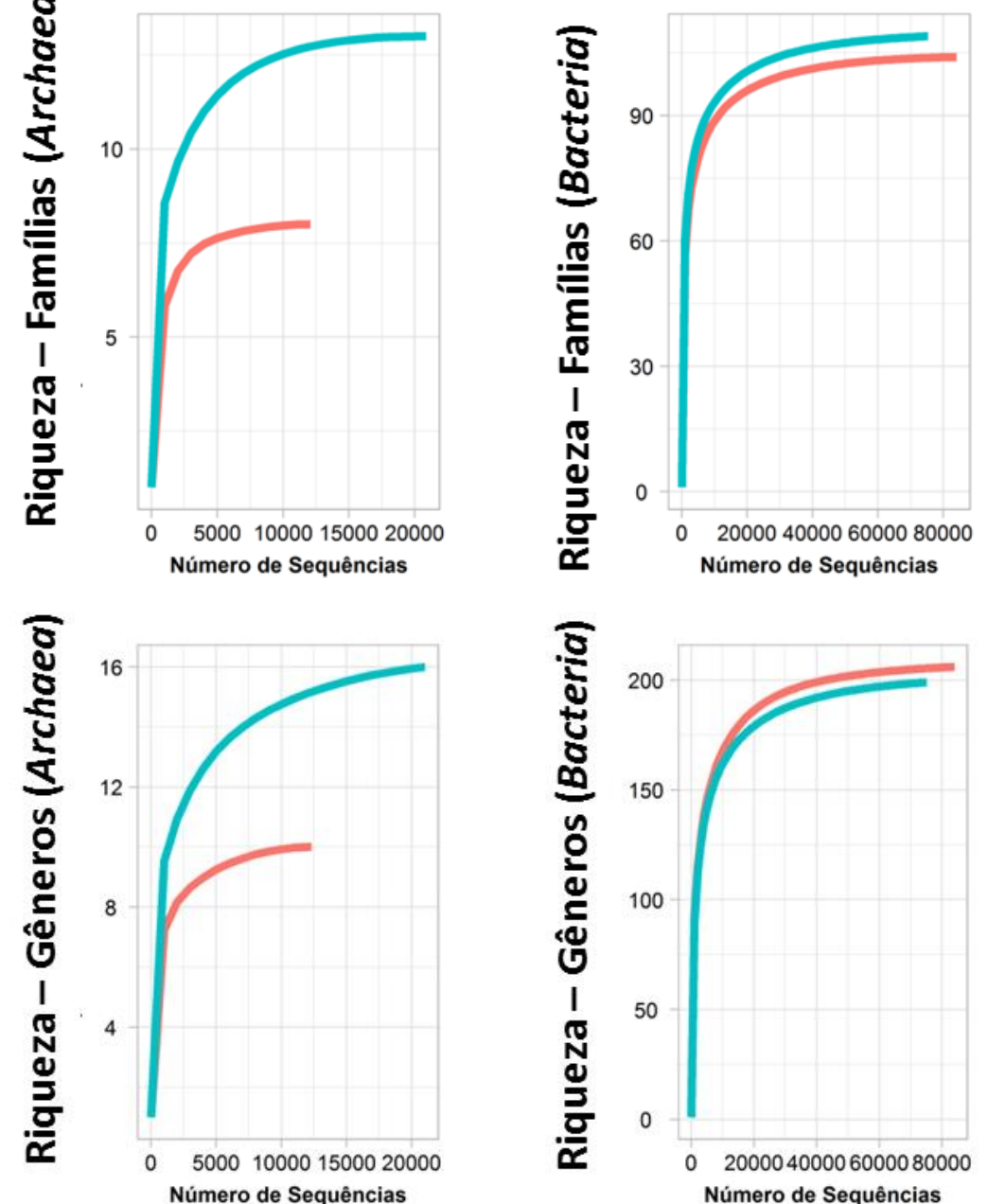

Figura 5.49: Curvas de rarefação definidas para os níveis de gênero e família das amostras 3A e 3G (a) e curvas de rarefação para as comunidades dos Domínios Archaea (b) e Bacteria (c). 
Os resultados das análises taxonômicas ao nível de filo estão apresentados na Figura 5.50. Na amostra obtida ao final da FASE 3A (53 dias de operação) foi observada a predominância dos filos Firmicutes (32,65\%), Bacteroidetes (17,80\%), Proteobacteria (13,27\%), Chloroflexi (12,26\%) e Synergistetes (7,32\%), pertencentes ao Domínio Bacteria, e do filo Euryarchaeota (11,71\%), pertencente ao Domínio Archaea (Figura 5.50). Após a operação do reator decorrida ao longo da ETAPA 3 (170 dias), a amostra 3G apresentou decréscimo nas abundâncias relativas referentes aos filos Firmicutes $(22,94 \%)$, Bacteroidetes $(11,96 \%)$ e Chloroflexi $(3,89 \%)$. Por outro lado, os filos que apresentaram um incremento na abundância relativa foram, principalmente, Proteobacteria $(18,76)$, Euryarchaeota $(18,68 \%)$ e Synergistetes $(10,13 \%)$ (Figura 5.50). 
FASE 3A

Crenarchaeota: $0.47 \%-$

Euryarchaeota: $11.71 \%$

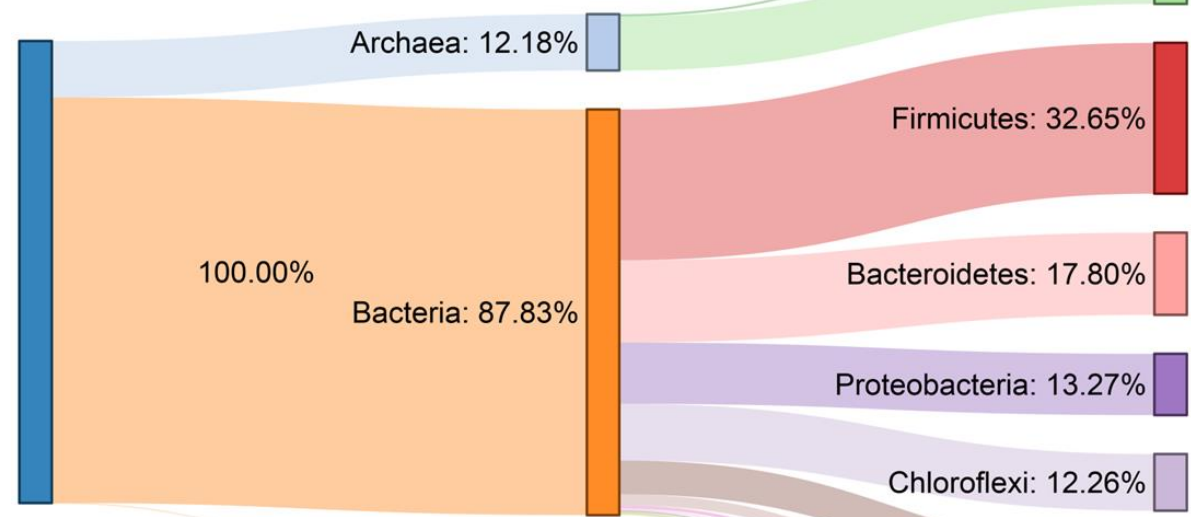

Synergistetes: $7.32 \%$

Unclassified: $0.01 \%$ _ D Deferribacteres: $2.36 \%$

Actinobacteria: $0.72 \%-$

Tenericutes: $0.38 \%-$

Thermotogae: $0.37 \%$

Spirochaetes: $0.21 \%-$

Acidobacteria: $0.14 \%$

Others Bac: $0.35 \%-$

Unclassified: $0.01 \%$

\section{FASE 3G}

Crenarchaeota: $2.81 \% \square$

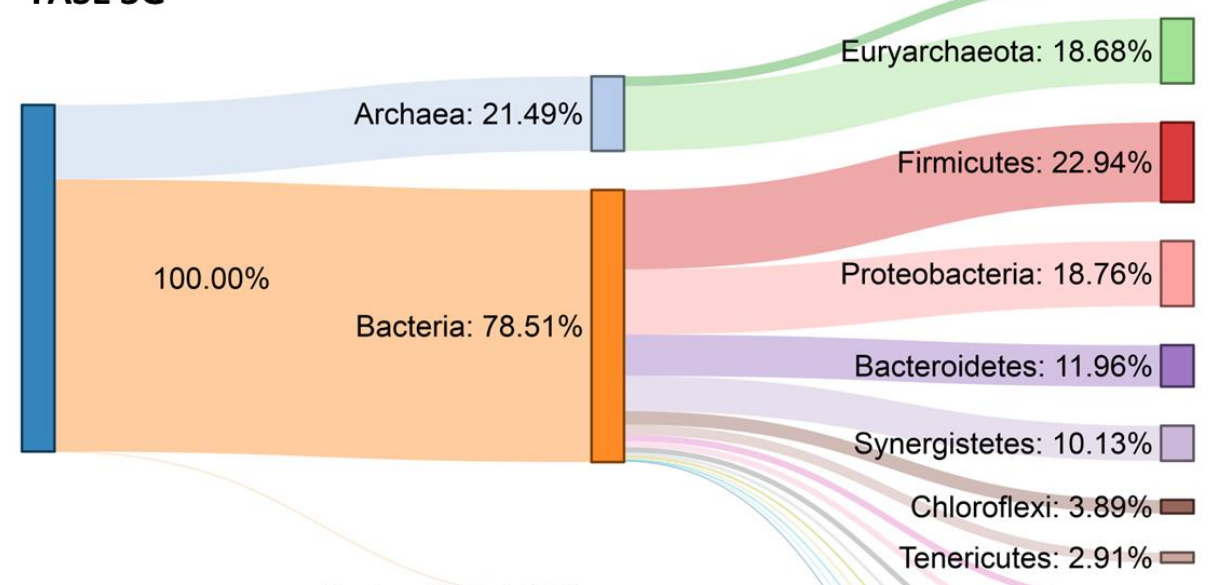

Unclassified: $0.23 \%$ Actinobacteria: $1.89 \%=$

Thermotogae: $1.72 \%=$

Spirochaetes: $1.52 \%=$

Acidobacteria: $0.91 \%-$

Cloacimonetes: $0.59 \%$ -

Planctomycetes: $0.53 \%$

Elusimicrobia: $0.24 \%-$

Verrucomicrobia: $0.19 \%$

Deferribacteres: $0.11 \%$

Unclassified: $0.23 \%$

Figura 5.50: Abundâncias relativas referentes aos níveis taxonômicos de Domínio e Filo nas amostras sequenciadas ao final das FASES 3A e 3G do DFSBR.

Fonte: $\mathrm{O}$ autor. 
Os filos predominantes encontrados nas amostras do reator ao final das FASES 3A e 3G (Figura 5.50) foram compatíveis com os filos caracterizados no inóculo proveniente de reator UASB tratando água residuária de abatedouro de aves (IN-1), conforme apresentado por SAKAMOTO et al. (2016). Os autores observaram predominância do filo Proteobacteria na amostra do lodo S2 (IN-1 no presente trabalho), um dos maiores filos de bactérias cujos membros são caracterizados por uma ampla diversidade metabólica, com representantes anaeróbios obrigatórios ou facultativos (GUPTA, 2000). O filo Bacteroidetes, o segundo mais abundante na amostra do referido inóculo (SAKAMOTO et al., 2016), por sua vez, é composto por organismos conhecidos pela sua habilidade em degradar proteínas e carboidratos (THOMAS et al., 2011). Já o filo Firmicutes, o terceiro filo de bactérias mais abundante de IN-1 (SAKAMOTO et al., 2016), e o mais predominante nas amostras do DFSBR (Figura 5.50), é conhecido por agrupar microrganismos fermentativos com habilidade de converter compostos orgânicos complexos em moléculas mais simples, passíveis de serem utilizadas por outros organismos (MADIGAN et al., 2000). Com relação ao Domínio Archaea, o filo Euryarchaeota foi o mais abundante nas amostras do reator, bem como no inóculo IN-1 (SAKAMOTO et al., 2016), sendo esse filo caracterizado por englobar todas as arqueias metanogênicas conhecidas (ANGEL et al., 2012).

Com relação ao nível taxonômico de gênero, conforme apresentado na Figura 5.51, observou-se o aumento da abundância relativa referente ao gênero Desulfovibrio (de 1,91\% para 6,37\%) entre as amostras 3A e 3G, o que esteve diretamente ligado ao tempo de exposição da biomassa às altas concentrações de sulfato proporcionadas no DFSBR. A esse gênero pertencem espécies de BRS capazes de utilizar diversos substratos como doadores de elétrons, entre os quais hidrogênio, formiato, lactato, piruvato, álcoois de cadeia curta, entre outros compostos orgânicos (VOORDOUW, 1995). O metabolismo quimiolitotrófico de Desulfovibrio sp. utilizando hidrogênio como única fonte de energia e $\mathrm{CO}_{2}$ mais acetato como 
fontes de carbono também já foi descrito por BADZIONG et al. (1979). Além do mais, representantes desse gênero já foram caracterizados por uma alta afinidade pelo sulfato, levando vantagens na competição com outros organismos sulfato-redutores (LAANBROEK et al., 1984). Esse fato pode explicar a restrição do número de indivíduos pertencentes ao gênero Desulfomicrobium (Figura 5.51.a), outro agrupamento de BRS (WIDDEL, 1988), cuja abundância relativa passou de 3,97\% para apenas 0,74\% ao longo da operação do DFSBR.

Aumento da abundância relativa do gênero Synergistes (de 5,44\% para 9,36\%) também foi observado (Figura 5.51.a). Indivíduos desse gênero foram relacionados com o consumo anaeróbio de acetato em associação com organismos metanogênicos acetotróficos do gênero Methanosaeta (ITO et al., 2011). A restrição da metanogênese observada durante as últimas fases operacionais da ETAPA 3 (Figura 5.39) e o aumento nas concentrações remanescentes de ácido acético (Figura 5.43) podem ter favorecido o enriquecimento de microrganismos desse grupo.

Por outro lado, o aumento da abundância relativa do gênero Dehalococcoides (de 1,48\% para 2,64\%; Figura 5.51.a), o qual é representado por bactérias anaeróbias exclusivamente redutoras de compostos organo-halogenados (LÖFFLER et al., 2013), pode ser indicativo de contaminação da vinhaça por compostos organoclorados. Infelizmente, essa hipótese não pode ser verificada. Uma outra explicação para essa observação pode estar ligada ao fato de alguns membros do gênero Dehalococcoides apresentarem um aparato genético com potencial enzimático de redução de enxofre, principalmente em indivíduos da espécie Dehalococcoides ethenogenes (YARZA et al., 2008), muito embora isso ainda não tenha sido comprovado experimentalmente.

Já o aumento da abundância relativa de sequências do gênero Mycoplasma (de 0,34\% para 2,59\%; Figura 5.51.a) pode estar relacionado com a disponibilidade de vitaminas, lipídios, proteínas e aminoácidos na vinhaça, dado que os indivíduos desse gênero apresentam 
requerimentos nutricionais específicos para viabilidade do seu crescimento (RODWELL; MITCHELL, 1979).

Abundâncias relativas do gênero Geobacter, o qual agrupa indivíduos ferro-redutores (LOVLEY et al., 1993), apresentou queda de 3,67\% para 1,00\% (Figura 5.51.a) entre as amostras 3A e 3G. A disponibilização na DAM do ferro exclusivamente em sua forma reduzida $\left(\mathrm{Fe}^{2+}\right)$ em conjunto com as estratégias adotadas para a minimização das entradas de $\mathrm{O}_{2}$ no sistema (conforme discutido na subseção 5.3.3), evitando-se assim a reoxidação do $\mathrm{Fe}^{2+}$ a $\mathrm{Fe}^{3+}$ e a sua posterior utilização como aceptor de elétrons, devem ter restringido o estabelecimento de microrganismos pertencentes a esse grupo.

Também o gênero Pelotomaculum, representativo de espécies degradadoras de propionato (IMACHI et al., 2007), apresentou diminuição em sua abundância relativa entre as amostras (de 2,14 \% a 0,46\%; Figura 5.51.a). Esse resultado corrobora observações reportadas na literatura, de que o ácido propiônico é mais favoravelmente oxidado via redução de sulfato, inclusive do ponto de vista termodinâmico (MUYZER; STAMS, 2008).

O gênero Clostridium, que engloba organismos com ampla diversidade metabólica e geralmente relacionado com processos fermentativos (WIEGEL et al., 2006), apresentou uma queda na abundância relativa da FASE 3A para a FASE 3G (Figura 5.51.a). Apesar da diminuição na abundância relativa desse grupo (de $12,11 \%$ para $8,37 \%$ ), a sua participação nas etapas iniciais da digestão anaeróbia da vinhaça, isto é, durante a fermentação de carboidratos e outros compostos orgânicos disponíveis, parece ter se mantido. Espécies do gênero Clostridium, tais quais Clostridium sulfidigenes, Clostridium thiosulfatireducen e Clostridium tunisiense, também estão relacionadas com a redução dissimilativa de enxofre via polissulfetos e tiossulfato (TAKAHASHI et al. 2010; SALLAM; STEINBÜCHEL, 2009). Uma vez que a introdução de ferro no sistema induziu a precipitação dos sulfetos em solução, espera-se a minimização da formação de compostos de enxofre em estados intermediários de 
oxidação, tais como o enxofre elementar, polissulfetos e tiossulfato. Assim, espécies dependentes desses compostos podem ter sido inibidas ao longo das fases operacionais mantidas com dosagem de DAM sintética, o que poderia ser uma das explicações para a diminuição da abundância desse gênero.

Com relação aos gêneros de arqueias, Methanosaeta foi o gênero que apresentou maior abundância relativa nas amostras 3A e 3G (11,31\% e 11,05\%, respectivamente) (Figura 5.51.b). Uma vez que indivíduos desse grupo são conhecidos por utilizarem exclusivamente acetato como fonte de carbono e energia (PATEL; SPROTT, 1990), confirmou-se o predomínio da metanogênese pela via acetoclástica no DFSBR.

Sequências dos gêneros Methanolinea e Methanocorpusculum aumentaram em termos de suas abundâncias relativas (de $0,02 \%$ para $1,15 \%$ e de $0,01 \%$ para $1,58 \%$, respectivamente) (Figura 5.51.b), sendo os organismos desses gêneros caracterizados pelo seu metabolismo hidrogenotrófico, capazes de utilizar $\mathrm{H}_{2} / \mathrm{CO}_{2}$ ou formiato para crescimento e produção de metano (SAKAI et al., 2012; ZELLNER et al., 1989).

Thermogymnomonas, gênero de arqueias não produtoras de metano, acidofílicas, moderadamente termofílicas $\left(33-67^{\circ} \mathrm{C}\right)$, heterotróficas e aeróbias estritas (ITOH et al., 2007), também apresentou um notável aumento de abundância relativa (de 0,06\% para 4,83\%; Figura 5.51.b), de forma que indivíduos desse grupo podem ter sido favorecidos pelo aumento da acidez da fase líquida do DFSBR. Vale ressaltar ainda que altas abundâncias relativas a esse gênero foram recentemente identificadas em amostras de sedimento de uma mina subterrânea de mercúrio abandonada (MESA et al., 2017), bem como em várias amostras de drenagens ácidas de minas ricas em metais (YANG et al., 2014). 
(a)

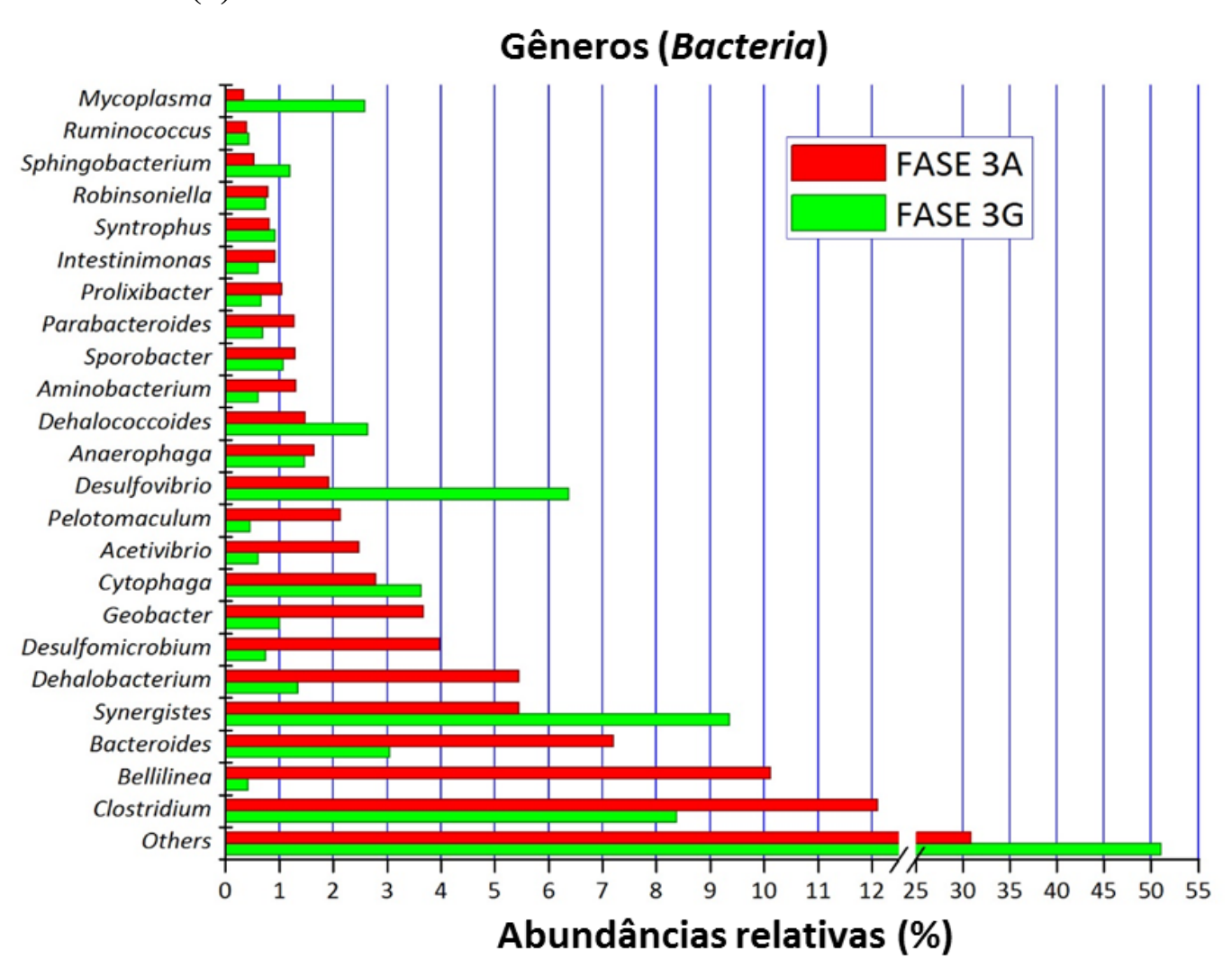

(b)

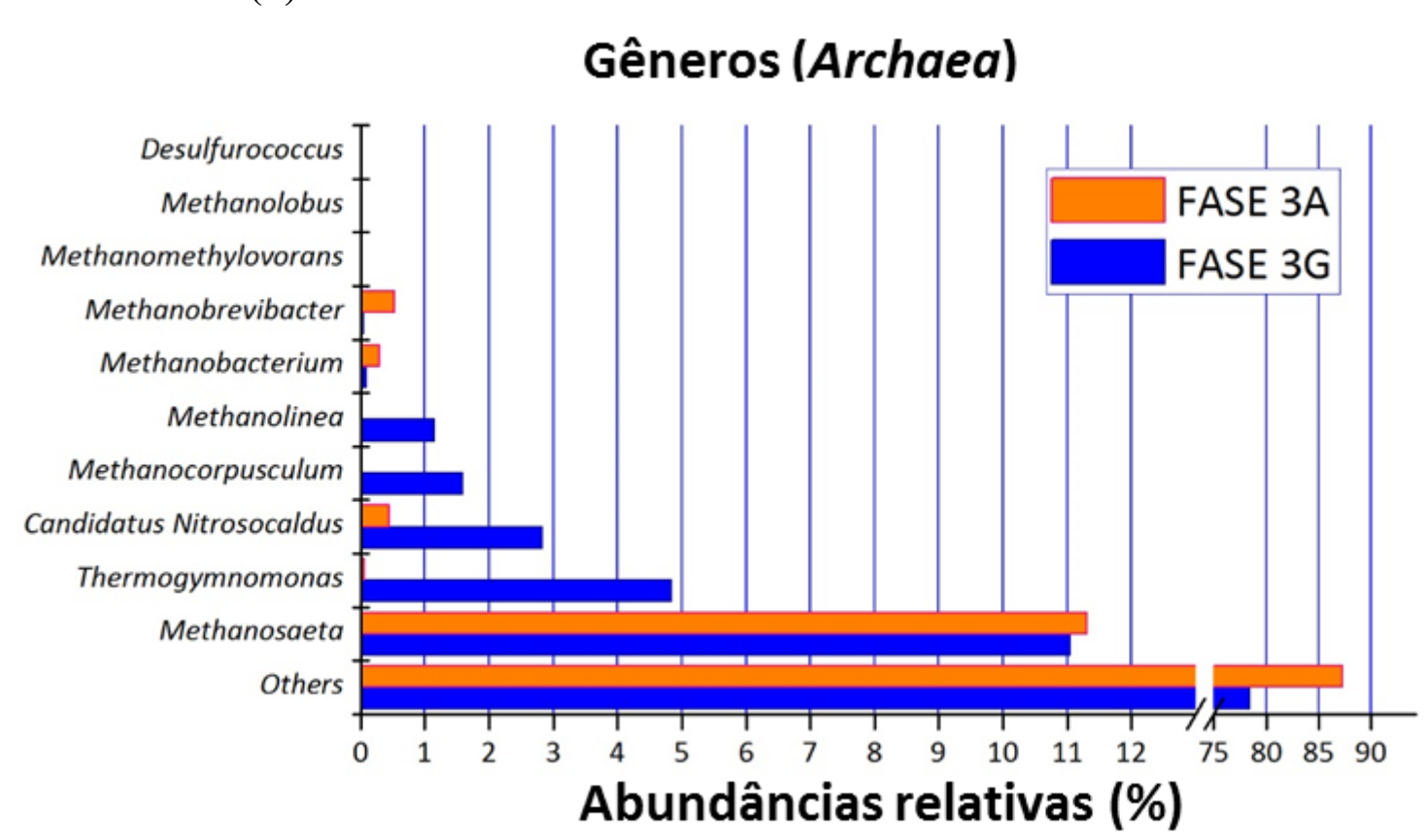

Figura 5.51. Abundâncias relativas de gêneros dos Domínios Bacteria (a) e Archaea (b) observadas nas amostras de biomassa do DFSBR ao final das FASES 3A e 3G.

Fonte: $\mathrm{O}$ autor. 
Por fim, os resultados da caracterização da comunidade microbiana estabelecida no DFSBR permitiram ressaltar o estabelecimento de associação entre os processos sulfatoredutores e metanogênicos no reator, à qual pode ser atribuída o sucesso do tratamento da DAM em co-digestão com a vinhaça.

Em termos gerais, apesar da diminuição da diminuição do pH no meio líquido no DFSBR ao longo da ETAPA 3, as populações metanogênicas (gênero Methanosaeta) foram preservadas, ao passo que a população de bactérias sulfato-redutoras (gênero Desulfovibrio) foi expressivamente enriquecida. A estratégia empregada, de abaixamento gradual (e não súbito) do $\mathrm{pH}$ do meio líquido, parece ter colaborado em evitar a falência imediata da metanogênese no sistema, por possibilitar a adaptação da biomassa.

A variabilidade de compostos orgânicos, bem como a presença de macro e micro nutrientes na vinhaça de cana-de-açúcar, também podem ser apontados como os fatores responsáveis pela manutenção de uma biomassa diversa e versátil, sustentando diversos metabolismos secundários no DFSBR.

\subsubsection{Estimativa do potencial energético do DFSBR tratando DAM em co- digestão com vinhaça de cana-de-açúcar}

O reaproveitamento do biogás rico em metano gerado no DFSBR tratando uma drenagem ácida em conjunto com vinhaça concentrada de cana-de-açúcar pode representar uma vantagem do ponto de vista econômico e ambiental, desde que as distâncias entre as usinas geradoras de vinhaça e as unidades de tratamento de DAM não sejam impeditivas para o transporte do substrato em questão. De fato, pelos extensos volumes gerados de DAM, é praticamente inviável realizar o tratamento dessa água residuária em um lugar distante da própria cava da mina, na qual a drenagem é gerada. 
Assim, para fins ilustrativos, o potencial de geração de energia a partir do biogás obtido no tratamento de uma DAM utilizando vinhaça como doador de elétrons foi estimado, levando em consideração as premissas já apresentadas na subseção 4.13.5, p. 101.

Partindo-se dos dados de produção de metano observados no DFSBR ao longo da ETAPA 3, das FASES 3B a 3G (nas quais simulou-se o tratamento de uma DAM com supressão da dosagem de álcali) foram calculados os potenciais energéticos mostrados na Tabela 5.17.

Tabela 5.17. Potencial de produção de energia a partir do biogás gerado no DFSBR tratando DAM utilizando vinhaça como doador de elétrons.

\begin{tabular}{|c|c|c|c|}
\hline $\begin{array}{l}\text { Fase } \\
\text { Operacional } \\
\end{array}$ & $\begin{array}{l}\text { Vazão de metano } \\
\text { observada }\left(m L . d^{-1}\right)\end{array}$ & $\begin{array}{l}\text { Rend }_{\mathrm{CH} 4} \\
\left(\mathrm{~m}^{3} \mathrm{CH}_{4} \cdot \mathrm{m}^{3} \text { vINHACA }\right)^{*}\end{array}$ & $\begin{array}{l}\text { PPE } \\
\left(\text { KWh.m }^{3} \text { VINHACA }^{-1}\right)^{*}\end{array}$ \\
\hline $3 B$ & 750 & 11,0 & 39,7 \\
\hline $3 C$ & 656 & 9,7 & 34,8 \\
\hline $3 \mathrm{D}$ & 450 & 6,6 & 23,8 \\
\hline $3 \mathrm{E}$ & 526 & 7,7 & 27,9 \\
\hline $3 F$ & 490 & 7,2 & 26,0 \\
\hline $3 \mathrm{G}$ & 458 & 6,7 & 24,3 \\
\hline
\end{tabular}

*Cálculos efetuados em termos de vinhaça adicionada ao DFSBR.

Fonte: $\mathrm{O}$ autor.

Devido à diminuição gradativa no pH afluente ao qual o reator foi submetido, como já amplamente discutido ao longo das subseções anteriores, menores produções de metano no sistema foram observadas durante as últimas fases operacionais. Assim, um menor rendimento observado de metano (em termos de volume de $\mathrm{CH}_{4}$ gerado por volume de vinhaça dosada ao sistema) também foi obtido. Isso implicou na queda do potencial energético do sistema quando submetido ao pH ácido de uma DAM sem adição de agentes alcalinizantes. 
Para casos mais específicos, em que as fontes geradoras de DAM estão situadas nas proximidades de usinas produtoras de açúcar e/ou etanol, ou seja, de usinas produtoras de vinhaça, o tratamento conjunto dessas águas residuárias pode se mostrar atrativo do ponto de vista econômico.

Vale ressaltar, uma vez mais, que as estimativas de ganho energético e autonomia para o transporte de vinhaça aqui apresentadas são preliminares. Outros fatores deverão ser levados em conta para o estudo da viabilidade econômica e ambiental de um projeto em escala maior.

Uma vez que a vinhaça utilizada como doador de elétrons para o DFSBR foi concentrada, apresentando alto teor de matéria orgânica, cada $1 \mathrm{~m}^{3}$ de vinhaça concentrada seria suficiente para efetuar o tratamento de cerca de $30 \mathrm{~m}^{3}$ de DAM (nas condições estudadas, ou seja, relação $\mathrm{DQO} / \mathrm{SO}_{4}{ }^{2-} \approx 2,0$ ). Caso seja desejável a utilização de vinhaça não concentrada, por exemplo, deve-se levar em conta o aumento do volume que será necessário transportar. Para efeitos comparativos, tomando por base uma vinhaça real diretamente coletada dos destiladores de uma usina de açúcar e etanol, com concentração de DQO total variando de 23,4 a 32,2 g.L. ${ }^{-1}$ ao longo da safra (FUESS, 2017), e valor médio de 28,3 \pm 4,6 gDQO. $\mathrm{L}^{-1}, 1 \mathrm{~m}^{3}$ de vinhaça seria o suficiente para o tratamento de apenas $7 \mathrm{~m}^{3}$ de DAM sob condições semelhantes às empregadas no presente estudo. Assim, para o tratamento de um mesmo volume de DAM, um volume 4,4 vezes maior de vinhaça não concentrada seria demandado em relação à vinhaça concentrada, resultando em um menor potencial de geração de energia (em termos de KWh.m ${ }^{3}$ vinHAÇA ${ }^{-1}$ ).

\subsubsection{Considerações finais relativas à ETAPA 3}

O estudo realizado durante a ETAPA 3 confirmou que a vinhaça de cana-de-açúcar se mostra um doador de elétrons adequado para a sulfetogênese, inclusive sob condições restritivas de $\mathrm{pH}$. De fato, a manutenção da atividade das BRS com altas eficiências de 
remoção de sulfato no sistema (próximas de 100\%) durante as fases operadas sem adição de álcali externo foi o fator chave para a manutenção do tamponamento do meio líquido no interior do reator, evitando o colapso do processo e garantindo a neutralização do efluente ácido tratado, validando a sub-hipótese 3A: A sulfetogênese estabelecida a partir da vinhaça de cana-de-açúcar possibilitará a neutralização de uma DAM sintética sem adição externa de álcali graças à geração de alcalinidade associada à redução de sulfato, provendo maior robustez ao processo.

Ademais, a diminuição do pH afluente não impactou negativamente as eficiências de remoção de ferro, mas ao contrário, favoreceu os processos de precipitação desse metal sob a forma de sulfetos insolúveis, ressaltando o potencial do reator DFSBR para o tratamento e neutralização de uma DAM sem a necessidade de introdução de agentes alcalinizantes, apesar da expressiva acidez encontrada nestas águas residuárias. Esse resultado validou a subhipótese 3B: A diminuição do pH afluente do DFSBR durante o tratamento de uma DAM sintética permitirá investigar a influência desse parâmetro sobre a precipitação de sulfetos metálicos no reator.

Menor participação da metanogênese no processo global de remoção de DQO, por outro lado, foi marcadamente induzida pela diminuição do pH e alcalinidade disponível no meio líquido. Em função desse resultado, a operação do DFSBR sem adição de álcali deverá ser realizada com menor dependência dessa via de remoção de DQO para o tratamento simultâneo das águas residuárias testadas, confirmando a sub-hipótese 3C: A supressão na dosagem de álcali externo implicará na acidificação do meio líquido, com modificação das populações microbianas presentes no sistema, e promoverá a restrição do metabolismo metanogênico, antes favorecido pelas condições aplicadas ao início da operação do reator. 
Todavia, apesar das condições mais restritivas relativas ao $\mathrm{pH}$ do meio líquido, populações de arqueias metanogênicas acetoclásticas (gênero Methanosaeta) foram mantidas no DFSBR, viabilizando a produção de metano em todas as fases operacionais da ETAPA 3. 


\section{CONCLUSÕES}

À luz dos objetivos inicialmente propostos para o presente estudo, e partindo dos resultados obtidos ao longo das três ETAPAS de operação do reator DFSBR, aplicado ao tratamento de DAM sintética em co-digestão com vinhaça, foram elencadas as seguintes conclusões:

I. A configuração do reator de leito fixo-estruturado e fluxo descendente (DFSBR) apresentou desempenho satisfatório no tratamento de uma DAM sintética sob relação $\mathrm{DQO} / \mathrm{SO}_{4}{ }^{2-}$ da ordem de 2,0 , verificando-se o estabelecimento de processos sulfetogênicos e metanogênicos associados, os quais concorreram para a obtenção das altas eficiências de remoção de sulfato (> 99\%) e DQO (> 90\%) observadas ( Objetivo específico 1: Sub-hipótese 1A) ;

II. A configuração do DFSBR se mostrou vantajosa para o tratamento das águas residuárias escolhidas, com favorecimento da precipitação e sedimentação de sulfetos de ferro. As eficiências de remoção de ferro alcançadas no reator (> 95\%) quando o mesmo foi submetido ao aumento da carga de ferro aplicada $\left(0,5\right.$ g.L $\left.L^{-1} \cdot d^{-1}\right)$ confirmaram o seu potencial para a viabilização da recuperação de metais a partir de DAM (Objetivo específico 1: Sub-hipótese 1B);

III. A diminuição do sulfeto dissolvido, induzida pelos mecanismos de precipitação de metais, permitiu elucidar a relevante contribuição do íon HS $^{-}$ para a capacidade tampão do meio líquido, especialmente em reatores sulfetogênicos (Objetivo específico 1: Sub-hipótese 1C);

IV. O padrão de escoamento do DFSBR nas condições ensaiadas se aproximou do modelo de mistura perfeita, mesmo na ausência de recirculação da fase líquida, graças à manutenção da produção de biogás, de forma que as maiores velocidades superficiais de escoamento não contribuíram para a melhoria do 
desempenho do DFSBR aplicado à precipitação de sulfetos metálicos. Dessa forma, a operação do sistema na ausência de recirculação se mostrou uma alternativa viável e mais atrativa para o tratamento de DAM visando à recuperação de sulfetos metálicos, especialmente pela diminuição dos gastos associados com a energia demandada pelo sistema de bombeamento do efluente (Objetivo específico 2: Sub-hipótese 2A);

V. Embora as maiores taxas de reciclo tenham resultado no cisalhamento e aumento do arraste de biomassa para fora do reator, não foi observada perda expressiva de desempenho do processo biológico, dada à adequada adesão do biofilme ao material suporte (polietileno de baixa densidade) utilizado (Objetivo específico 2: Sub-hipótese 2B);

VI. A vinhaça empregada se mostrou um doador de elétrons satisfatório para o tratamento biológico de DAM, promovendo o estabelecimento de uma biomassa versátil no DFSBR, responsável pela manutenção concomitante dos processos de redução de sulfato e produção de metano, viabilizando a codigestão desses efluentes gerados em larga escala no Brasil (Objetivo específico 2: Sub-hipótese 2C);

VII. A geração de alcalinidade pelo metabolismo das BRS sob as condições estudadas favoreceu a robustez do tratamento anaeróbio no DFSBR, garantindo com sucesso a neutralização do efluente ácido, mesmo após a supressão da dosagem de álcali externo, sustentado elevadas eficiências de remoção de sulfato (> 97\%) (Objetivo específico 3: Sub-hipótese 3A);

VIII. A operação do reator com valores menores de $\mathrm{pH}$ afluente não prejudicou o desempenho do DFSBR relativo à formação e precipitação dos sulfetos metálicos, possibilitando a manutenção de altas eficiências de remoção de ferro 
(93-97\%) com apreciável estabilidade (Objetivo específico 3: Sub-hipótese $\underline{3 \mathrm{~B}}$;

IX. Apesar da menor participação da metanogênese no processo global de remoção de matéria orgânica, a manutenção da produção de metano no DFSBR, mesmo sob condições mais restritivas para o metabolismo das AM, ressaltou o potencial de produção de energia pelo reaproveitamento do biogás gerado pela co-digestão das águas residuárias em questão (Objetivo específico 3: Subhipótese 3C);

X. A estratégia de diminuição gradual da dosagem de álcali no DFSBR ao longo da ETAPA 3 também evitou uma modificação acentuada da biomassa, com a manutenção dos principais metabolismos envolvidos no tratamento de DAM em co-digestão com a vinhaça. Os gêneros Desulfovibrio e Methanosaeta foram identificados como principais responsáveis pelos processos associados de redução de sulfato e metanogênese acetoclástica, respectivamente, colaborando para a viabilidade da proposta de tratamento estudada (Objetivo específico 3: Sub-hipótese 3C).

Por fim, as conclusões do presente trabalho de pesquisa permitiram validar a hipótese central de estudo: A utilização do DFSBR promoverá a melhoria dos balanços energético e econômico do tratamento de DAM pela eliminação da dosagem de substratos orgânicos comerciais, substituídos por uma água residuária complexa (vinhaça), com potencial para a recuperação de metais de interesse para a atividade industrial e pelo reaproveitamento do biogás rico em metano gerado. 


\section{SUGESTÕES PARA TRABALHOS FUTUROS}

Baseando-se nos resultados obtidos, e diante das limitações encontradas no presente estudo, as sugestões a seguir foram traçadas para propiciar maiores avanços no entendimento dos processos envolvidos, bem como para possibilitar uma avaliação mais ampla da aplicação prática do DFSBR no tratamento de DAM:

I. A diminuição do $\mathrm{pH}$ do meio líquido restringiu a contribuição da metanogênese no processo de remoção de matéria orgânica, o que indicou que o tratamento de uma DAM em condições viáveis, isto é, sem a dosagem de elevadas quantias de agentes alcalinizantes, deverá ser estudada em condições operacionais menos dependentes dessa via metabólica, isto é, em menores relações $\mathrm{DQO} / \mathrm{SO}_{4}{ }^{2-}$, favoráveis ao predomínio da sulfetogênese e com menor requerimento por doadores de elétrons;

II. Uma vez que o ferro foi utilizado como metal de referência para investigar o potencial do DFSBR aplicado ao tratamento de DAM com interesse voltado para a recuperação dos metais removidos da fase líquida, torna-se necessário estudar o comportamento do sistema proposto quando submetido a uma DAM real, ou ao menos o seu desempenho na precipitação de um meio sintético enriquecido com diferentes metais, usualmente presentes em diversas DAM;

III. A definição de um procedimento de descarte do material precipitado mais rigoroso, associado à aplicação de metodologias analíticas mais refinadas, podem ser considerados importantes desafios a serem enfrentados em vista da obtenção de balanços de massa mais consistentes, para comprovação do potencial de recuperação de sulfetos metálicos no DFSBR, bem como para determinação das espécies de sulfetos ou outros complexos metálicos formados no sistema; 
IV. A utilização de diferentes materiais suportes no DFSBR para estudo da influência do material escolhido sobre os processos de recuperação de metais, aderência microbiana, colmatação do leito e aumento da limitação à transferência de massa após longos períodos de operação também representam interessantes itens a serem acessados em trabalhos futuros;

V. Investigação dos efeitos da aplicação de TDHs mais elevados sobre a eficiência de remoção da matéria orgânica, para definição de um TDH ótimo, que apresente menores concentrações residuais de DQO no efluente tratado;

VI. E, por fim, o estudo do reator DFSBR tratando uma DAM real associada à codigestão de outros efluentes orgânicos como doadores de elétrons para o processo, especialmente águas residuárias com alta concentração de matéria orgânica, o que possibilita o transporte de menores volumes de resíduo para a realização do tratamento. 


\section{REFERÊNCIAS BIBLIOGRÁFICAS}

ADORNO, M.A.T.; HIRASAWA, J.S.; VARESCHE, M.B.A. Development and Validation of Two Methods to Quantify Volatile Acids $\left(\mathrm{C}_{2}-\mathrm{C}_{6}\right)$ by GC/FID: Headspace (Automatic and Manual) and Liquid-Liquid Extraction (LLE). American Journal of Analytical Chemistry, v.5, n.07, p.406-414, 2014a.

ADORNO, M.A.T.; MIRANDOLA, C.A.S.; PIMENTA, D.F.N.; TOMITA, I.N. Development and validation of a method (GC/TCD) to determine $\mathrm{N}_{2}, \mathrm{CH}_{4}, \mathrm{CO}_{2}$ and $\mathrm{H}_{2} \mathrm{~S}$ in biogas. In: LATIN AMERICAN WORKSHOP AND SYMPOSIUM ON ANAEROBIC DIGESTION, 11, 2014, La Habana. Proceedings... , La Habana, p.1636-1641, 2014 b.

ALVES, I. Caracterização de grânulos de reator UASB empregado no processamento de vinhaça. 2015. 85 p. Dissertação (Mestrado) - Escola de Engenharia de São Carlos, Universidade de São Paulo, São Carlos, 2015.

ANGEL, R.; CLAUS, P.; CONRAD R. Methanogenic archaea are globally ubiquitous in aerated soils and become active under wet anoxic conditions. ISME Journal. v.6, p.847-862, 2012.

AKCIL, A.; KOLDAS, S. Acid Mine Drainage (AMD): causes, treatment and case studies. Journal of Cleaner Production, v.14, p.1139-1145, 2006.

ANZOLA-ROJAS, M.P. Estratégias para a produção contínua de hidrogênio em reator anaeróbio de leito fixo. 2014. 161 p. Tese (Doutorado) - Escola de Engenharia de São Carlos, Universidade de São Paulo, São Carlos, 2014.

ANZOLA-ROJAS, M.P.; ZAIAT, M. A novel anaerobic down-flow structured-bed reactor for long-term stable $\mathrm{H}_{2}$ energy production from wastewater. Journal of Chemical Technology and Biotechnology, v.91, p.1551-1561, 2015.

ANZOLA-ROJAS, M.P.; ZAIAT, M.; DE WEVER, H. Improvement of hydrogen production via ethanol-type fermentation in an anaerobic down-flow structured bed reactor. Bioresource Technology, v.202, 42-49, 2016.

APHA, AWWA, WEF. Standard methods for examination of water and wastewater. 21 ed. Washington, DC, USA: American Public Health Association / American Water Works Association / Water Environment Federation, 2005. 
AQUINO, S.F.; CHERNICHARO, C.A.L. Acúmulo de ácidos graxos voláteis (AGVs) em reatores anaeróbios sob estresse: causas e estratégias de controle. Engenharia Sanitária e Ambiental, v.10, n.2, p.152-161, 2005.

AQUINO, S.F.; CHERNICHARO, C.A.L., FORESTI, E.; SANTOS, M.L.F.; MONTEGGIA, L.O. Metodologias para determinação da atividade metanogênica específica (AME) em lodos anaeróbios. Engenharia Sanitária e Ambiental, v.12, n.2, p.192-201, 2007.

BADZIONG, W.; DITTER, B.; THAUER, R.K. Acetate and carbon dioxide assimilation by Desulfovibrio vulgaris (Marburg), growing on hydrogen and sulfate as sole energy source. Archives of Microbiology, v.123, p.301-305, 1979.

BARRERA, E.L.; SPANJERS, H.; DEWULF, J.; ROMERO, O.; ROSA, E. The sulfur chain in biogas production from sulfate-rich liquid substrates: a review on dynamic modeling with vinasse as model substrate. Journal of Chemical Technology and Biotechnology, v.88, p.1405-1420, 2013.

BARRERA, E.L.; SPANJERS, H.; ROMERO, O.; ROSA, E.; DEWULF, J. Characterization of the sulfate reduction process in the anaerobic digestion of a very high strength and sulfate rich vinasse. Chemical Engineering Journal, v.248, p.383-393, 2014.

BEKMEZCI, O.K.; UCAR, D.; KAKSONEN, A.H.; SAHINKAYA, E. Sulfidogenic biotreatment of synthetic acid mine drainage and sulfide oxidation in anaerobic baffled reactor. Journal of Hazardous Materials, v.189, n.3, p.670-676, 2011.

BENEDETTO, J.S.; ALMEIDA, S.K.; GOMES, H.A.; VAZOLLER, R.F.; LADEIRA, A.C.Q. Monitoring of sulfate-reducing bacteria in acid water from uranium mines. Minerals Engineering, V.18, P.1341-1343, 2005.

BERTOLINO, S.M.; RODRIGUES, I.C.B; GUERRA-SÁ, R.; AQUINO, S.F.; LEÃO, V.A. Implications of volatile fatty acid profile on the metabolic pathway during continuous sulfate reduction. Journal of environmental management, v.103, p.5-23, 2012.

BIJMANS, M.F.M.; DOPSON, M.; ENNIN, F.; LENS, P.N.; BUISMAN, C.J.N. Effect of Sulfide Removal on Sulfate Reduction at $\mathrm{pH} 5$ in a Hydrogen Fed Gas-Lift Bioreactor. Journal of Microbiology and Biotechnology, v.18, n.11, p.1809-1818, 2008.

CABRAL, C.B.G.; CHERNICHARO, C.A.L.; PLATZER, C.J.; BARJENBRUCH, M.; BELLIFILHO, P. Evaluation of Biogas Production and Energy Recovery Potential in 5 Full-Scale 
WWTPs with UASB Reactors. Chemical Engineering \& Process Techniques, v.3, n.3, 1043, 2017.

CADAVID, D.L.; ZAIAT, M.; FORESTI, E. Performance of horizontal-flow anaerobic immobilized sludge (HAIS) reactor treating synthetic substrate subjected to decreasing COD to sulfate ratios. Water Science and Technology, v.39, n.10-11, p.99-106, 1999.

CALLANDER, I.J.; BARFORD, J.P. Recent advances in anaerobic digestion technology. Process Biochemistry, v.18, p.24-30, 1983.

CAMARGO, E.F.M.; RATUSZNEI, S.M.; RODRIGUES, J.A.D.; ZAIAT, M.; BORZANI, W. Treatment of low-strength wastewater using immobilized biomass in a sequencing batch external loop reactor: Influence of the medium superficial velocity on the stability and performance. Brazilian Journal of Chemical Engineering, v.19, n.3, p.267-275, 2002.

CAMILOTI, P.R.; MOCKAITIS, G.; RODRIGUES, J.A.D.; DAMIANOVIC, M.H.R.Z.; FORESTI, E.; ZAIAT, M. Innovative anaerobic bioreactor with fixed-structured bed for simultaneous sulfate reduction and organic matter removal. Journal of Chemical Technology and Biotechnology, v.89, p.1044-1050, 2013.

CAO, J.; ZHANG, G.; MAO, Z.; LI, Y.; FANG, F.; CHAO, Y. Influence of electron donors on the growth and activity of sulfate-reducing bacteria. International Journal of Mineral Processing, n.106-109, p.58-64, 2012.

CAPORASO, J.G.; LAUBER, C.L.; WALTERS, W.A.; BERG-LYONS, D.; LOZUPONE, C.A.; TURNBAUGH, P.J.; FIERER, N.; KNIGHT, R. Global patterns of 16S rRNA diversity at a depth of millions of sequences per sample. Proceedings of the National Academy of Sciences, v.108, p.4516-4522, 2012.

CASTRO, H.F.; WILLIAMS, N.H.; OGRAM, A. Phylogeny of sulfate-reducing bacteria. FEMS Microbiology Ecology, v.31, p.1-9, 2000.

CELIS-GARCIA, L.B.; RAZO-FLORES, E.; MONROY, O. Performance of a down-flow fluidized-bed reactor under sulfate reduction conditions using volatile fatty acids as electron donors. Biotechnology and Bioengineering, v.97, p.771-779, 2007.

CHEN, K.Y.; MORRIS, J.C. Kinetics of Oxidation of Aqueous Sulfide by $\mathrm{O}_{2}$. Environmental Science and Technology, v.6, p.529-537, 1972. 
CHEN, T.; YAN, B.; LEI, C.; XIAO, X. Pollution control and metal resource recovery for acid mine drainage. Hydrometallurgy, v.147-148, p.112-119, 2014.

CHERNICHARO, C.A.L. Anaerobic reactors. 1 ed. London: IWA Publishing, 2007.

CHOI, E.; RIM, J.M. Competition and Inhibition of Sulfate Reducers and Methane Producers in Anaerobic Treatment. Water Science and Technology, v.23, n.7-9, p.1259-1264, 1991.

COLLERAN, E.; FINNEGAN, S.; LENS, P. Anaerobic treatment of sulphate-containing waste streams. Antonie van Leeuwenhoek, v.67, n.1, p.29-46, 1995.

DAMIANOVIC, M.H.R.Z.; FORESTI, E. Anaerobic degradation of synthetic wastewaters at different levels of sulfate and COD/Sulfate ratios in horizontal-flow anaerobic reactors (HAIB). Environmental Engineering Science, v.24, n.3, p.383-393, 2007.

DAMIANOVIC, M.H.R.Z.; FORESTI, E. Sulfate and organic matter removal from paper recycling plant wastewater in a horizontal-flow anaerobic immobilized biomass (HAIB) reactor. Process Biochemistry, n.44, p.1050-1054, 2009.

DELFORNO, T.P. Degradação de surfactante aniônico em reator EGSB sob condição metanogênica e ferro redutora com água residuária de lavanderia comercial. 2014. 203 p. Tese (Doutorado) - Escola de Engenharia de São Carlos, Universidade de São Paulo, São Carlos, 2014.

DELGADO, A.G.; PARAMESWARAN, P.; FAJARDO-WILLIAMS, D.; HALDEN, R.U.; KRAJMALNIK-BROWN, R. Role of bicarbonate as a $\mathrm{pH}$ buffer and electron sink in microbial dechlorination of chloroethenes. Microbial Cell Factories, 11:128, 2012.

DEL NERY, V.; NARDI, I.R.; DAMIANOVIC, M.H.R.Z.; POZZI, E.; AMORIM, A.K.B.; ZAIAT, M. Long-term operating performance of a poultry slaughterhouse wastewater treatment plant. Resources, Conservation and Recycling, v.50, p.102-114, 2007.

DESANTIS, T. Z.; HUGENHOLTZ, P.; LARSEN, N.; ROJAS, M.; BRODIE, E.L.; KELLER, K.; HUBER, T.; DALEVI, D.; HU, P.; ANDERSEN, G.L. Greengenes, a chimera-checked 16S rRNA gene database and workbench compatible with ARB. Applied and Environmental Microbiology, v.72, n.7, p.5069-5072, 2006.

DILALLO, R.; ALBERTSON, O.E. Volatile acids by direct titration. Journal of water pollution control federation, v.33, n.4, p.356-356, 1961. 
ELLIOT, P.; RAGUSA, S.; CATCHESIDE, D. Growth of sulfate-reducing bacteria under acidic conditions in an upflow anaerobic bioreactor as a treatment system for acid mine drainage. Water Research, v.32, n.12, p.3724-3730, 1998.

ESPOSITO, G.; VEEKEN, A.; WEIJMA, J.; LENS, P.N.L. Use of biogenic sulfide for ZnS precipitation. Separation and Purification Technology, v.51, p.31-39, 2006.

FADIRAN, A.O.; DLAMINI, C.L.; THWALA, J.M. Environmental Assessment of Acid Mine Drainage Pollution on Surface Water Bodies around Ngwenya Mine, Swaziland. Journal of Environmental Protection, v.5, 164-173, 2014.

FORESTI, E. Fundamentos do Processo de Digestão Anaeróbia. In: Viñas, M.; Soubes, M.; Borzacconi, L.; Muxi, L. (Org.). Tratamento Anaeróbio. Montevideo: Universidad de la Republica, 1994, p. 97-110.

FUESS, L.T.; GARCIA, M.L. Implications of stillage land disposal: A critical review on the impacts of fertigation. Journal of Environmental Management, v.145, p.210-229, 2014.

FUESS, L.T. Biodigestão anaeróbia termofílicas de vinhaça em sistemas combinados do tipo acidogênico-metanogênico para potencialização da recuperação de bioenergia em biorrefinarias de cana-de-açúcar de primeira geração. 2017. 346 p. Tese (Doutorado) - Escola de Engenharia de São Carlos, Universidade de São Paulo, São Carlos, 2017.

GALLEGOS-GARCIA， M.; CELIS， L.B.; RANGEL-MÉNDEZ， R.; RAZO-FLORES， E. Precipitation and recovery of metal sulfides from metal containing acidic wastewater in a sulfidogenic down-flow fluidized bed reactor. Biotechnology and Bioengineering, v.102, n.1, p.91-99, 2009.

GARCÍA, C.; MORENO, D.A.; BALLESTER, A.; BLÁZQUEZ, M.L.; GONZÁLEZ, F. Bioremediation of an industrial acid mine water by metal-tolerant sulphate-reducing bacteria. Minerals Engineering, v.14, n.9, p.997-1008, 2001.

GARCÍA-BALBOA, C.; VICENTE, M.S.; BLAZQUEZ, M.L.; GONZÁLEZ, F.; MUÑOZ, J.A.; BALLESTER, A. Iron Speciation in Dissimilatory Fe(III)-reducing Cultures. Geomicrobiology Journal, v.28, p.371-379, 2011.

GAZEA, B.; ADAM, K.; KONTOPOULOS, A. A review of passive systems for the treatment of acid mine drainage. Minerals Engineering, v.9, n.1, p.23-42, 1996. 
GHIGLIAZZA, R.; LODI, A.; ROVATTI, M. Kinetic and process considerations on biological reduction of soluble and scarcely soluble sulfates. Resources, Conservation and Recycling, v.29, p.181-194, 2000.

GIL-GARCIA, C.; GODOI, L.A.G.; FUESS, L.T.; DAMIANOVIC, M.H.R.Z. Performance improvement of a thermophilic sulfate-reducing bioreactor under acidogenic conditions: Effects of diversified operating strategies. Journal of Environmental Management, v.207, p.303-312, 2018.

GIMÉNEZ, J.B.; CARRETERO, L.; GATTI, M.N.; MARTÍ, N.; BORRÁS, L.; RIBES, J.; SECO, A. Reliable method for assessing the COD mass balance of a submerged anaerobic membrane bioreactor (SAMBR) treating sulphate-rich municipal wastewater. Water Science and Technology, v.66, n.3, p.494-502, 2012.

GLEISNER, M.; HERBERT, R.B.; KOCKUM, P.C.F. Pyrite oxidation by Acidithiobacillus ferrooxidans at various concentrations of dissolved oxygen. Chemical Geology, v.225, p.16-29, 2006.

GODOI, L.A.G. Interferência da sulfetogênese sobre a produção de metano a partir de águas residuárias ricas em carboidratos. 2014. 102 p. Dissertação (Mestrado). Escola de Engenharia de São Carlos, Universidade de São Paulo, São Carlos, 2014.

GODOI, L.A.G.; DAMIANOVIC, M.H.R.Z.; FORESTI, E. Sulfidogenesis interference on methane production from carbohydrate-rich wastewater. Water Science \& Technology, v.72, n.9, p.1644$1652,2015$.

GODOI, L.A.G.; FORESTI, E.; DAMIANOVIC, M.H.R.Z. Down-flow fixed-structured bed reactor: An innovative reactor configuration applied to acid mine drainage treatment and metal recovery. Journal of Environmental Management, v.197, p.597-604, 2017a.

GODOI, L.A.G.; SANTOS, C.E.D.; FORESTI, E.; DAMIANOVIC, M.H.R.Z. Evaluating and Refining Alkalinity Calculations Due to Sulfide and Bicarbonate Accessed by Titration in Anaerobic Sulfate-Reducing Bioreactors. Water, Air, \& Soil Pollution, v.228, p.228-322, 2017 b.

GOMES, M.T.M.S.; EÇA, K.S.; VIOTTO, L.A. Concentração da vinhaça por microfiltração seguida de nanofiltração com membranas. Pesquisa Agropecuária Brasileira, v.46, n.6, p.633-638 , 2011.

GONÇALVES, M.M.M.; DA COSTA, A.C.A.; LEITE, S.G.F.; SANT’ANNA JR., G.L. Heavy metal removal from synthetic wastewaters in an anaerobic bioreactor using stillage from ethanol distilleries as a carbon source. Chemosphere, v.69, p.1815-1820, 2007. 
GRAY, N.F. Environmental impact and remediation of acid mine drainage: a management problem. Environmental Geology, v.27, p.358-361, 1997.

GREBEN, H.A.; MARAE, J.P.; MNQANQENI, S. Comparison between sucrose, ethanol and methanol as carbon and energy sources for biological sulfate reduction. Water Science and Technology, v.41, n.12, p.247-253, 2000.

GREBEN, H.A.; TJATJI, M.; MAREE, J.P. COD/SO ${ }_{4}$ ratios using propionate and acetate as the energy source for the biological sulphate removal in Acid Mine Drainage. In: INTERNATIONAL MINE WATER ASSOCIATION SYMPOSIUM, 8, 2004, Newcastle Upon Tyne. Proceedings... , Newcastle upon Tyne, 2004.

GRIFFITHS, R.I.; WHITELEY, A.S.; O’DONNELL, A.G. Rapid method for Coextration of DNA and RNA from natural environments for analysis of Ribosomal DNA and rRNA-based microbial community composition. Applied and Environmental Microbiology, v.66, p.5488-5491, 2000.

GUPTA, R.S. The phylogeny of proteobacteria: relationships to other eubacterial phyla and eukaryotes. FEMS Microbiology Reviews, v.24, n.4, p.367-402, 2000.

HAO, O.J. Sulphate-reducing bacteria. In: MARA, D.; HORAN, N.J. (Ed.). The Handbook of Water and Wastewater Microbiology. London: Academic Press, 2003. p.459-469.

HARADA, H.; UEMURA, S.; MOMONOI, K. Interaction between sulphate reducing bacteria and methane-producing bacteria in UASB reactors fed with low strength wastes containing different levels of sulphate. Water Research, v.28, n.2, p.355-367, 1994.

HILL, D.T., COBB, S.A., BOLTE, J.P. Using volatile fatty acid relationships to predict anaerobic digester failure. Transactions of the ASAE, v.30, n.2, p.496-501, 1987.

HILTON, B.L.; OLESZKIEWICZ, J.A. Sulfide-induced inhibition of anaerobic digestion. Journal of Environmental Engineering, n.114, p.1377-1391, 1988.

HOLT, J.G.; KRIEG, N.R.; SNEATH, P.H.A.; STALEY, J.T.; WILLIAMS, S.T. [Ed] Bergey's manual of determinative bacteriology, 9 ed. Baltimore: Williams \& Wilkins, 1994.

HULSHOFF POL, L.W.; LENS, P.N.L.; STAMS, A.J.M.; LETTINGA, G. Anaerobic treatment of sulphate-rich wastewaters. Biodegradation, v.9, p.213-224, 1998.

IMACHI, H.; SAKAI, S.; OHASHI, A.; HARADA, H.; HANADA, S.; KAMAGATA, Y.; SEKIGUCHI, Y. Pelotomaculum propionicicum sp. nov., an anaerobic, mesophilic, obligately 
syntrophic, propionate-oxidizing bacterium. International Journal of Systematic and Evolutionary Microbiology, v.57, p.1487-1492, 2007.

ITO, T.; YOSHIGUCHI, K.; ARIESYADY, H.D.; OKABE, S. Identification of a novel acetateutilizing bacterium belonging to Synergistes group 4 in anaerobic digester sludge. ISME Journal. v.5, n.12, p.1844-1856, 2011.

ITOH, T.; YOSHIKAWA, N.; TAKASHINA, T. Thermogymnomonas acidicola gen. nov., sp. nov., a novel thermoacidophilic, cell wall-less archaeon in the order Thermoplasmatales, isolated from a solfataric soil in Hakone, Japan. International Journal of Systematic and Evolutionary Microbiology, v.57, p.2557-2561, 2007.

JIMÉNEZ-RODRÍGUEZ, A.M.; DURÁN-BARRANTES, M.M.; BORJA, R.; SÁNCHEZ, E.; COLMENAREJO, M.F.; RAPOSO, F. Heavy metals removal from acid mine drainage water using biogenic hydrogen sulphide and effluent from anaerobic treatment: effect of $\mathrm{pH}$. Journal of Hazardous Materials, v.165, p.759-765, 2009.

JOHNSON, D.B.; HALLBERG, K.B. Acid mine drainage remediation options: A review. Science of the Total Environment, v.338, p.3-14, 2005.

JOHNSON, D.B.; SEN, A.M.; KIMURA, S.; ROWE, O.F.; HALLBERG, K.B. Novel biosulfidogenic system for selective recovery of metals from acidic leach liquors and waste streams. Mineral Processing and Extractive Metallurgy, v.115, p.19-24, 2006.

KAKSONEN, A.H.; FRANZMANN, P.D.; PUHAKKA, J.A. Performance and ethanol oxidation kinetics of sulfate-reducing fluidized-bed reactor treating acidic metal-containing wastewater. Biodegradation, v.14, p.207-217, 2003.

KAKSONEN, A.H.; PUHAKKA, J.A. Sulfate reduction based bioprocesses for the treatment of acid mine drainage and the recovery of metals. Engineering in Life Sciences, v.7, p.541-564, 2007.

KONARZEWSKI, V.H.; SCHNEIDER, I.A.H. Atenuação de efluente de aterro sanitário utilizando-se a mistura do chorume com drenagem ácida de minas. In: XXIII ENCONTRO NACIONAL DE MINÉRIOS E METALURGIA EXTRATIVA, 2, 2009, Gramado. Anais... , Gramado, 2009, p.219-223.

KOSCHORRECK, M. Microbial sulphate reduction at a low pH. FEMS Microbiology Ecology, v.64, p.329-342, 2008. 
KOSTER, I.W.; RINZEMA, A.; DE VEGT, A.L.; LETTINGA, G. Sulfide inhibition of the methanogenic activity of granular sludge at different pH levels. Water Research, v.20, n.12, p.1561-1567, 1986.

KUDO, Y.; NAKAJIMA, T.; MIYAKI, T.; OYAIZU, H.. Methanogen flora of paddy soils in Japan. FEMS Microbiology Ecology, v.22, p.39-48, 1997.

JAIN, S.R.; MATTIASSON, B. Acclimatization of methanogenic consortia for low $\mathrm{pH}$ biomethanation process. Biotechnology Letters, v.20, n.8, p.771-775, 1998.

JENKINS, R.; MOORE, R.C. A proposed modification to the classical method of calculating alkalinity in natural waters. Journal American Water Works Association, v.69, n.1, p.56-60, 1977.

LAANBROEK, H.J.; GEERLIGS, H.J.; SIJTSMA, L.; VELDKAMP, H. Competition for sulfate and ethanol among Desulfobacter, Desulfobulbus, and Desulfovibrio species isolated from intertidal sediments. Applied and Environmental Microbiology, v.47, 329-334, 1984.

LAZAROVA, V.; MANEM, J. Biofilm characterization and activity analysis in water and wastewater treatment. Water Research, v.19, n.10, p.2227-2245, 1995.

LENS, P.N.L.; VISSER, A.; JANSSEN, A.J.H.; HULSHOFF POL, L.W.; LETTINGA, G. Biotechnological treatment of sulfate-rich wastewaters. Critical Reviews in Environmental Science and Technology, v.28, n.1, p.41-88, 1998.

LENS, P.N.L.; KUENEN, J.G. The biological sulfur cycle: Novel opportunities for environmental biotechnology. Water Science and Technology, v.44, n.8, p.57-66, 2001.

LENS, P.N.L.; VALlERO, G.; ESPOSITO, G.; ZANDVOORT, M. Perspectives of sulfate reducing bioreactors in environmental biotechnology. Reviews in Environmental Science \& Biotechnology, n.1, p.311-325, 2002.

LENZ, M.; HULLEBUSCH, E.D.V.; HOMMES, G.; CORVINI, P.F.X.; LENS, P. N.L. Selenate removal in methanogenic and sulfate-reducing upflow anaerobic sludge bed reactors. Water Research, v.42, p.2184-2194, 2008.

LEVENSPIEL, O. Engenharia das reações químicas. São Paulo: Edgard Blucher, 2000.

LEWIS, A.M. Review of metal sulphide precipitation. Hydrometallurgy, v.104, p.222-234, 2010.

LIAMLEAM, W.; ANNACHHATRE, A.P. Electron donors for biological sulfate reduction. Biotechnology Advances, n.25, p.452-463, 2007. 
LÖFFLER, F.E.; YAN, J.; RITALAHTI, K.M.; ADRIAN, L.; EDWARDS, E.A.; KONSTANTINIDIS, K.T.; MÜLLER, J.A.; FULLERTON, H.; ZINDER, S.H; SPORMANN, A.M. Dehalococcoides mccartyi gen. nov., sp. nov., obligately organohalide-respiring anaerobic bacteria relevant to halogen cycling and bioremediation, belong to a novel bacterial class, Dehalococcoidia classis nov., order Dehalococcoidales ord. nov. and family Dehalococcoidaceae fam. nov., within the phylum Chloroflexi. International Journal of Systematic and Evolutionary Microbiology, v.63, p.625-635, 2013.

LONGO, R.R. Geração de metano em reator UASB: avaliação de parâmetros de monitoramento para controle do processo de tratamento anaeróbio de vinhaça. 2015. 146 p. Dissertação (Mestrado) - Escola de Engenharia de São Carlos, Universidade de São Paulo, São Carlos, 2015.

LOPES, F.A. Drenagem ácida de minas concentrada como fonte de ferro para a coagulação e para a reação de fenton: Aplicações no tratamento de esgoto sanitário de uma instituição de ensino superior. 2011. 99 p. Dissertação (Mestrado) - Escola de Engenharia, Universidade Federal do Rio Grande do Sul, Porto Alegre, 2011.

LOVLEY, D.R.; DWYER, D.F.; KLUG, M.J. Kinetic analysis of competition between sulfate reducers and methanogens for hydrogen in sediments. Applied and Environmental Microbiology, v.43, n.6, p.1373-1379, 1982.

LOVLEY, D.R.; GIOVANNONI, S.J.; WHITE, D.C.; CHAMPINE, J.E.; PHILLIPS, E.J.; GORBY, Y.A.; GOODWIN, S. Geobacter metallireducens gen. nov. sp. nov., a microorganism capable of coupling the complete oxidation of organic compounds to the reduction of iron and other metals. Archives of Microbiology, v.159, n.4, p.336-344, 1993.

MADIGAN, M.T.; MARTINKO, J.M.; PARKER, J. Brock biology of microorganisms. 9 ed. Upper Saddle River: Prentice Hall/Pearson Education, 2000.

MAILlACHERUVU, K.Y.; PARKIN, G.F.; PENG, C.Y.; KUO, W.C.; OONGE, Z.I.; LEBDUSCHKA V. Sulfide Toxicity in Anaerobic Systems Fed Sulfate and Various Organics. Water Environment Research, v.65, n.2, p.100-8109, 1993.

MCCARTNEY, D.M.; OLESZKIEWICZ, J.A. Sulfide inhibition of anaerobic degradation of lactate and acetate. Water Research, v.25, n.2, p.203-209, 1991.

MCMURDIE, P.J.; HOLMES, S. phyloseq: an R package for reproducible interactive analysis and graphics of microbiome census data. PLoS ONE, v.8, n.4, e61217. 
MEIER, J.; PIVA, A.; FORTIN, D. Enrichment of sulfate-reducing bacteria and resulting mineral formation in media mimicking pore water metal ion concentrations and $\mathrm{pH}$ conditions of acidic pit lakes. FEMS Microbiology Letters, v.79, p.69-84, 2012.

MELLO, J.W.V.; DUARTE, H.A.; LADEIRA, A.C.Q. Origem e Controle do Fenômeno Drenagem Ácida de Mina. Cadernos Temáticos de Química Nova na Escola, n.8, p.24-29, 2014.

MENEZES, J.C.S.S. Produção de coagulantes férricos na mineração de carvão. 2009. 120 p. Tese (Doutorado) - Escola de Engenharia, Universidade Federal do Rio Grande do Sul, Porto Alegre, 2009.

MERSMANN, A. Crystallization and Precipitation. Chemical Engineering and Processing - Process Intensification, v.38, p.345-353, 1999.

MESA, V.; GALLEGO, J.L.R.; GONZÁLEZ-GIL, R.; LAUGA, B.; SÁNCHEZ, J.; MÉNDEZGARCÍA, C.; PELÁEZ, A. Bacterial, Archaeal, and Eukaryotic Diversity across Distinct Microhabitats in an Acid Mine Drainage. Frontiers in Microbiology,v.8, n.1756, p.1-17, 2017.

MICHAUD, S.; BERNET, N.; BUFFIÈRE, P.; ROUSTAN, M.; MOLETTA, R. Methane yield as a monitoring parameter for the start-up of anaerobic fixed film reactors. Water Research, v.36, p.13851391, 2002.

MICHAUD, S.; BERNET, N.; ROUSTAN, M.; DELGENÈS, J.P. Influence of Hydrodynamic Conditions on Biofilm Behavior in a Methanogenic Inverse Turbulent Bed Reactor. Biotechnology Progress, v.19, p.858-863, 2003.

MOCKAITIS, G. Remoção de $\mathrm{Cd}^{2+}$ e $\mathrm{Cu}^{2+}$ de águas residuárias utilizando biorreator anaeróbio contínuo de leito fixo ordenado. 2011. 325 p. Tese (Doutorado) - Escola de Engenharia de São Carlos, Universidade de São Paulo, São Carlos. 2011

MOCKAITIS, G.; RODRIGUES, J.A.D.; FORESTI, E.; ZAIAT, M. Toxic effects of cadmium $\left(\mathrm{Cd}^{2+}\right)$ on anaerobic biomass: kinetic and metabolic implications. Journal of Environmental Management, v.106, p.75-84, 2012.

MOCKAITIS, G.; PANTOJA, J.L.R.; RODRIGUES, J.A.D.; FORESTI, E.; ZAIAT, M. Continuous anaerobic bioreactor with a fixed-structure bed (ABFSB) for wastewater treatment with low solids and low applied organic loading content. Bioprocess and Biosystems Engineering, v.37, n.7, p. 1361-1368, 2014. 
MOHAN, S.V.; BABU, V.L.; BHASKAR, Y.V.; SARMA, P.N. Influence of recirculation on the performance of anaerobic sequencing batch biofilm reactor (AnSBBR) treating hypersaline composite chemical wastewater. Bioresource Technology, v.98, p.1373-1379, 2007.

MORAES, B.S.; ZAIAT, M.; BONOMI, A. Anaerobic digestion of vinasse from sugarcane ethanol production in Brazil: Challenges and perspectives. Renewable and Sustainable Energy Reviews, v.44, p.888-903, 2015.

MOSEY, F.E. The toxicity of cadmium to anaerobic digestion: its modification by inorganic anions. Water Pollution Control, v.70, p.584-598, 1971.

MOSEY, F.E.; HUGHES, D.A. The toxicity of heavy metal ions to anaerobic digestion. Water Pollution Control, v.74, p.18-39, 1975.

MOTSI, T. Remediation of acid mine drainage using natural zeolite. 2010. 242 p. Thesis $(\mathrm{PhD})-$ University of Birmingham, Birmingham, 2010.

MOUNTFORT, D.O.; ASHER, R.A. Effect of inorganic sulfide on the growth and metabolism of Methanosarcina barkeri strain DM. Applied and Environmental Microbiology, v.37, n.4, p.670675, 1979.

MUDHOO, A.; KUMAR, S. Effects of heavy metals as stress factors on anaerobic digestion processes and biogas production from biomass. International Journal of Environmental Science \& Technology, v.10, p.1383-1398, 2013.

MUYZER, G.; STAMS, A.J.M. The ecology and biotechnology of sulphate-reducing bacteria. Nature Reviews: Microbiology, v.6, p.441-454, 2008.

MUTTON, M.A.; ROSSETTO, R.; MUTTON, M.J.R. Agricultural Use of Stillage. In: CORTEZ, L.A.B. (Coord.). Sugarcane bioethanol - R\&D for Productivity and Sustainability, São Paulo: Editora Edgard Blücher, 2014. p.423-440.

MYERS, R. J. The new low value for the second dissociation constant for H2S: its history, its best value, and its impact on the teaching of sulfide equilibria. Journal of Chemical Education, v.63, n.8, p.687-690, 1986.

NAGPAL, S.; CHUICHULCHERM, S.; PEEVA, L.; LIVINGSTON, A. Microbial sulfate reduction in a liquid-solid fluidized bed reactor. Biotechnology and Bioengineering, v.70, p.370-380, 2000. 
NASCIMENTO, M.R.L. Remoção e recuperação de urânio de águas ácidas de mina por resina de troca iônica. 1998. 93 p. Dissertação (Mestrado) - Departamento de Química, Universidade Federal de São Carlos, São Carlos, 1998.

NATARAJ, S.K.; HOSAMANI, K.M.; AMINABHAVI, T.M. Distillery wastewater treatment by the membrane-based nanofiltration and reverse osmosis processes. Water Research, v.40, p.23492356, 2006.

NAVARRO, A.R.; SEPÚLVEDA, M.C.; RUBIO, M.C. Bio-concentration of vinasse from the alcoholic fermentation of sugar cane molasses. Waste Management, v.20, p.581-585, 2000.

NICOLAIEWSKY, E. Tratamento físico-químico do vinhoto: floculação, sedimentação e filtração. Brasil Açucareiro, v.98, p.23-30, 1981.

NIELSEN, P.H. Biofilm dynamics and kinetics during high-rate sulfate reduction under anaerobic conditions. Applied and Environmental Microbiology, v.53, n.1, p.27-32, 1987.

NUBEL, U.; ENGELEN, B.; FELSKE, A.; SNAIDR, J.; WIESHUBER, A.; AMANN, R.I.; LUDWIG, W.; BACKHAUS, H. Sequence Heterogeneities of Genes Encoding 16S rRNAs in Paenibacillus polymyxa Detected by Temperature Gradient Gel Electrophoresis. Journal of Bacteriology, v.178, n.19, p.5636-5643, 1996.

NUNES, M.A.S. Tratamento combinado de drenagem ácida de minas e esgoto doméstico. 2010. 63 p. Dissertação (Mestrado) - Escola de Engenharia, Universidade Federal do Rio Grande do Sul, Porto Alegre, 2010.

O'FLAHERTY, V.; MAHONY, T.; O'KENNEDY, R.; COLLERAN, E. Effect of $\mathrm{pH}$ on growth kinetics and sulphide toxicity thresholds of a range of methanogenic, syntrophic and sulphatereducing bacteria. Process Biochemistry, v.33, n.5, p.555-569, 1998.

OMIL, F.; LENS, P.N.L.; VISSER, A.; HULSHOFF POL, L.W.; LETTINGA, G. Long-Term competition between sulfate reducing and methanogenic bacteria in UASB reactors treating volatile fatty acids. Biotechnology and Bioengineering, n. 57, p.676-685, 1998.

OVERMEIRE, A.; LENS, P.N.L.; VERSTRAETE, W. Mass transfer limitation of sulfate in methanogenic aggregates. Biotechnology and Bioengineering, v.44, p.387-391, 1994.

PATEL, G.B.; SPROTT, G.D. Methanosaeta concilii gen. nov. sp. nov. ("Methanothrix concilii") and Methanosaeta thermoacetophila nom. rev., comb. nov. International Journal of Systematic Bacteriology, v.40, n.1, p.79-82, 1990. 
PAUSS, A.; ANDRE, G.; PERRIER, M.; GUIOT, S.R. Liquid-to-gas mass transfer in anaerobic processes: inevitable transfer limitations of methane and hydrogen in the biomethanation process. Applied and Environmental Microbiology, v.56, n.6, p. 1636-1644, 1990.

PARNAUDEAU, V.; CONDOM, N.; OLIVER, R.; CAZEVIEILlE, P.; RECOUS, S. Vinasse organic matter quality and mineralization potential, as influenced by raw material, fermentation and concentration processes. Bioresource Technology, n.99, p.1553-1562, 2008.

PEIXOTO, G. Sistema fermentativo de duas fases para a produção de hidrogênio e metano a partir de esgoto sanitário combinado com águas residuárias industriais. 2011. 191 p. Tese (Doutorado) - Escola de Engenharia de São Carlos, Universidade de São Paulo, São Carlos, 2011.

POINAPEN, J.; EKAMA, G.A.; WENTZEL, M.C. Biological sulphate reduction with primary sewage sludge in an upflow anaerobic sludge bed (UASB) reactor - Part 2: Modification of simple wet chemistry analytical procedures to achieve COD and S mass balances. Water SA, v.35, n.5, p.535-542, 2009.

RAJESHWARI, K.V.; BALAKRISHNAN, M.; KANSAL, A.; LATA, K.; KISHORE, V.V.N. Stateof-the-art of anaerobic digestion technology for industrial wastewater treatment. Renewable and Sustainable Energy Reviews, v.4, p.135-156, 2000.

RAMOS, A.C.T.; RATUSZNEI, S.M.; RODRIGUES, J.A.D.; ZAIAT, M. Mass transfer improvement of a fixed-bed anaerobic sequencing batch reactor with liquid-phase circulation. Interciencia, v.28, n.4, p. 214-219, 2003.

REIS, M.A.M.; ALMEIDA, J.S.; LEMOS, P.C.; CARRONDO, M.J.T. Effect of Hydrogen Sulfide on Growth of Sulfate Reducing Bacteria. Biotechnology and Bioengineering, v.40, p.593-600, 1992.

RICKARD, D. Kinetics of FeS precipitation: Part 1. Competing reaction mechanisms. Geochimica et Cosmochimica Acta, v.59, p.4367-4379, 1995.

RICKARD, D.; LUTHER, G.W. Chemistry of iron sulfides. Chemical Reviews, v.107, p.514-516, 2007.

RIPLEY, L.E.; BOYLE, W.C.; CONVERSE, J.C. Improved alkalimetric monitoring for anaerobic digestion of high-strength wastes. Journal of Water Pollution Control Federation, n.58, p.406465, 1986. 
ROCHA, V.C. Processamento anaeróbio de vinhaça pré-tratada com biopolímero à base de cálcio. 2012. 104 p. Dissertação (Mestrado) - Escola de Engenharia de São Carlos, Universidade de São Paulo, São Carlos, 2012.

RODRIGUEZ, R.P.; OLIVEIRA, G.H.D.; RAIMUNDI, I.M.; ZAIAT, M. Assessment of a UASB reactor for the removal of sulfate from acid mine water. International Biodeterioration \& Biodegradation, v.74, p.48-53, 2012.

RODRIGUEZ, R.P.; ZAIAT, M. Influence of carbon source and inoculum type on anaerobic biomass adhesion on polyurethane foam in reactors fed with acid mine drainage. Bioresource Technology, v.102, p.5060-5065, 2011.

RODRIGUEZ, R.P. Aplicação de reatores anaeróbios para remoção de sulfato de águas de drenagem ácida de minas. 2010. 174 p. Tese (Doutorado) - Escola de Engenharia de São Carlos, Universidade de São Paulo, São Carlos, 2010.

RODWELL, A.W.; MITCHELL, A. Nutrition, growth and reproduction. In: BARILE, M.F.; RAZIN, S. (Ed.). The Mycoplasmas, Cell Biology, New York: Academic Press, v.1, 1979, p.103-139.

SAHINKAYA, E.; OZKAYA, B.; KAKSONEN, A.H.; PUHAKKA, J.A. Sulfidogenic fluidizedbed treatment of metal-containing wastewater at low and high temperatures. Biotechnology and Bioengineering, v.96, n.6, p.1064-1072, 2007.

SAHINKAYA, E.; GUNGOR, M. Comparison of sulfidogenic up-flow and down-flow fluidizedbed reactors for the biotreatment of acidic metal-containing wastewater. Bioresource Technology, v.101, p.9508-9514, 2010.

SAHINKAYA, E.; DURSUN, N.; OZKAYA, B.; KAKSONE, A.H. Use of landfill leachate as a carbon source in a sulfidogenic fluidized-bed reactor for the treatment of synthetic acid mine drainage. Minerals Engineering, v.48, p.56-60, 2013.

SAKAI, S.; EHARA, M.; TSENG, I-C.; YAMAGUCHI, T.; BRÄUER, S.L.; CADILLOQUIROZ, H.; ZINDER, S.H.; IMACHI, H. Methanolinea mesophila sp. nov., a hydrogenotrophic methanogen isolated from rice field soil, and proposal of the archaeal family Methanoregulaceae fam. nov. within the order Methanomicrobiales. International Journal of Systematic and Evolutionary Microbiology, v.62, p.1389-1395, 2012.

SAKAMOTO, I.K.; POZZI, E.; NERY, V.; OKADA, D.Y.; VARESCHE, M.B.A. Microbial community characterization of granulated sludge from UASB reactors (full-scale) used in poultry slaughterhouse wastewater treatment systems by Illumina Miseq sequencing. In: LATIN 
AMERICAN WORKSHOP AND SYMPOSIUM ON ANAEROBIC DIGESTION, 12, 2016, Cusco. Proceedings..., Cusco, 2016.

SALLAM, A.; STEINBÜCHEL, A. Clostridium sulfidigenes sp. nov., a mesophilic, proteolytic, thiosulfate- and sulfur-reducing bacterium isolated from pond sediment. International Journal of Systematic and Evolutionary Microbiology, v.59, n.7, p.1661-1665, 2009.

SANCHES-ANDREA, I.; SANZ, J.L.; BIJMANS, M.F.M.; STAMS, A.M.J. Sulphate reduction at low pH to remediate acid mine drainage. Journal of Hazardous Materials, v.269, p.98-109, 2014.

SANDER, R. Compilation of Henry's law constants, version 3.99. Atmospheric Chemistry and Physics Discussion, v.14, p.29615-30521, 2014.

SANTEGOEDS, C.M.; DAMGAARD, L.R.; HESSELINK, G.; ZOPFI, J.; LENS, P.; MUYZER, G.; BEER, D. Distribution of Sulfate-Reducing and Methanogenic Bacteria in Anaerobic Aggregates Determined by Microsensor and Molecular Analyses. Applied and Environmental Microbiology, v.65, n.10, p.4618-4629, 1999.

SARTI, A.; ZAIAT, M. Anaerobic treatment of sulfate-rich wastewater in an anaerobic sequential batch reactor (AnSBR) using butanol as the carbon source. Journal of Environmental Management, v.92, n.6, p.1537-1541, 2011.

SARTI, A.; SILVA, A.J.; ZAIAT, M.; FORESTI, E. The treatment of sulfate-rich wastewater using an anaerobic sequencing batch biofilm pilot-scale reactor. Desalination, v.249, n.1, p.241246, 2009.

SIERRA-ALVAREZ, R.; HOLLINGSWORTH, J.; ZHOU, M.S. Removal of copper in an integrated sulfate reducing bioreactor-crystallization reactor system. Environmental Science and Technology, v.41, n.4, p.1426-1431, 2007.

SPEECE, R. E. Anaerobic biotechnology for industrial wastewater, Environmental Science and Technology, v.17, n.9, p.416-427, 1983.

SPEECE, R.E. Anaerobic biotechnology for industrial wastewaters. Nashville: Archae Press, 1996.

STAMS, A.J.M.; PLUGGE, C.M.; DE BOK, F.A.M.; VAN HOUTEN, B.H.G.W.; LENS, P.N.L.; DIJKMA, H.; WEIJMA, J. Metabolic interactions in methanogenic and sulfate-reducing bioreactors. Water Science \& Technology, v.52, n.1-2, p.13-20, 2005. 
SULZBACH, T.S. Biorreatores a base de biocarvão para a remoção de sulfato e elementos-traço em águas de drenagem ácida de mina. 2015. 94 p. Dissertação (Mestrado) - Centro de Ciências Biológicas, Universidade Federal de Santa Catarina, Florianópolis, 2015.

SUN, J.; HU, J.; SHARMA, K.R.; NI, B-J.; YUAN, Z. Stratified Microbial Structure and Activity in Sulfide- and Methane-Producing Anaerobic Sewer Biofilms. Applied and Environmental Microbiology, v.80, n.22, p.7042-7052, 2014.

TABAK, H.H.; HOLDER, E.L.; KUPFERLE, M.J.; HAINES, J.R. Use of hydrogen respirometry to determine metal toxicity to sulfate reducing bacteria. In: ANNUAL WEST COAST CONFERENCE OF ASSOCIATION FOR ENVIRONMENTAL HEALTH SCIENCE AND INTERNATIONAL SOCIETY ENVIRONMENTAL FORENSICS, 14, 2004, San Diego. Proceedings... , San Diego, 2004, p.15-19.

TACONI, K.A.; ZAPPI, M.E.; FRENCH, W.T.; L.R., BROWN. Methanogenesis under acidic pH conditions in a semi-continuous reactor system. Bioresource Technology, v.99, 8075-8081, 2008.

TAKAHASHI, Y.; SUTO, K.; INOUE, C. Polysulfide reduction by Clostridium relatives isolated from sulfate-reducing enrichment cultures. Journal of Bioscience and Bioengineering, v.109, n.4, p.372-380, 2010.

THOMAS, F.; HEHEMANN, J.H.; REBUFFET, E.; CZJZEK, M.; MICHEL, G. Environmental and gut bacteroidetes: The food connection. Frontiers in Microbiology,v.2, n.93, p.1-16, 2011.

TSUKAMOTO, T.K.; MILLER, G.C. Methanol as a carbon source for microbiological treatment of acid mine drainage. Water Research, v. 33, n.6, p.1365-1370, 1999.

TSUKAMOTO, T.K.; KILLION, H.A.; MILLER, G.C. Column experiments for microbiological treatment of acid mine drainage: low-temperature, low-pH and matrix investigations. Water Research, v.38, n.6, p.1405-1418, 2004.

TORRES, P. Desempenho de um reator anaeróbio de manta de lodo (UASB) de bancada no tratamento de substrato sintético simulando esgotos sanitários. 1992. 185 p. Dissertação (Mestrado) - Escola de Engenharia de São Carlos, Universidade de São Paulo, São Carlos, 1992.

TOUZEL, J. P.; ALBAGNAC, G. Isolation and characterization of Methanococcus-Mazei strain MC3. FEMS Microbiology Letters, v.16, n.2-3, p.241-245, 1983. 
UCAR, D.; BEKMEZCI, O.K.; KAKSONEN, A.H.; SAHINKAYA, E. Sequential precipitation of $\mathrm{Cu}$ and $\mathrm{Fe}$ using a three-stage sulfidogenic fluidized-bed reactor system. Minerals Engineering, v.24, n.11, p.1100-1105, 2011.

UTGIKAR, V.P.; HARMON, S.M.; CHAUDHARY, N.; TABAK, H.H.; GOVIND, R.; HAINES, J.R. Inhibition of sulfate-reducing bacteria by metal sulfide formation in bioremediation of acid mine drainage. Environmental Toxicology, v.17, n.1, p.40-48, 2002.

VEEKEN, A.H.M.; DE VRIES, D.; VAN DER MARK, A.; RULKENS, W. Selective precipitation of heavy metals as controlled by a sulfide-selective electrode. Separation Science and Technology, v.38, p.1-19, 2003a.

VEEKEN, A.H.M.; AKOTO, L.; HULSHOFF POL, L.W.; WEIJMA, J. Control of the sulfide $\left(\mathrm{S}_{2}{ }^{-}\right)$ concentration for optimal zinc removal by sulfide precipitation in a continuously stirred tank reactor. Water Research, v.37, p.3709-3717, 2003 b.

VELASCO, A.; RAMÍREZ, M.; VOLKE-SEPÚLVEDA, T.; GONZÁLEZ-SÁNCHEZ, A.; REVAH, $\mathrm{S}$. Evaluation of feed $\mathrm{COD} /$ sulfate ratio as a control criterion for the biological hydrogen sulfide production and lead precipitation. Journal of Hazardous Materials, v.151, p.407-413, 2008.

VIEIRA, B.F.; COUTO, P.T.; SANCINETTI, G.P.; KLEIN, B.; VAN ZYL, D.; RODRIGUEZ, R.P. The effect of acidic $\mathrm{pH}$ and presence of metals as parameters in establishing a sulfidogenic process in anaerobic reactor. Journal of Environmental Science and Health, Part A: Toxic/Hazardous Substances and Environmental Engineering, v.0, n.0, p.1-5, 2016.

VILELA, R.S. Remoção de matéria orgânica de águas residuárias com elevada concentração de sulfato pelas vias sulfetogênica e metanogênica combinadas. 2012. 120p. Dissertação (Mestrado) Escola de Engenharia de São Carlos, Universidade de São Paulo, São Carlos, 2012.

VILELA, R.S.; DAMIANOVIC, M.H.R.Z.; FORESTI, E. Removing organic matter from sulfate-rich wastewater via sulfidogenic and methanogenic pathways. Water Science \& Technology, v.69, n.8, p.1669-1675, 2014.

VILLA-GOMEZ D.; ABABNEH H.; PAPIRIO S.; ROUSSEAU D.P.L.; LENS, P.N.L. Effect of sulfide concentration on the location of the metal precipitates in inversed fluidized bed reactors. Journal of Hazardous Materials, v.192, p.200-207, 2011.

VIOLLIER, E.; INGLETT, P.W.; HUNTER, K.; ROYCHOUDHURY, A.N.; VAN CAPPELLEN, P. The ferrozine method revisited: $\mathrm{Fe}(\mathrm{II}) / \mathrm{Fe}(\mathrm{III})$ determination in natural Waters. Applied Geochemistry, v.15, p.785-790, 2000. 
VOORDOUW, G. The Genus Desulfovibrio: The Centennial. Applied and Environmental Microbiology, v.61, n.8, p.2813-2819, 1995.

WAYBRANT, K.R.; BLOWS, D.W.; PTACEK, C.J. Selection of reactive mixtures for use in permeable reactive walls for treatment of mine drainage. Environmental Science and Technology, v.32, p.1972-1979, 1998.

WANG Y., ZHANG Y., WANG J., MENG L. Effects of volatile fatty acid concentrations on methane yield and methanogenic bacteria. Biomass Bioenergy, v.33, p.848-853, 2009.

WIDDEL, F. Microbiology and ecology of sulfate- and sulfur-reducing bacteria. In: ZEHNDER, A.J.B. (Ed.). Biology of anaerobic microorganisms. New York: Wiley, 1988, p.469-585.

WIEGEL, J.; TANNER, R.; RAINEY, F.A. An Introduction to the Family Clostridiaceae. In: DWORKIN, M.; FALKOW, S.; ROSENBERG, E.; SCHLEIFER, K-H.; STACKEBRANDT, E. (Ed.) The Prokaryotes. Volume 4: Bacteria: Firmicutes, Cyanobacteria, 3 ed., New York: Springer, 2006, p.654-678.

WILKIE, A.; RIEDESEL K.; OWENS, J. Stillage characterization and anaerobic treatment of ethanol stillage from conventional and cellulosic feedstocks. Biomass and Bioenergy, n.19, p.63$102,2000$.

WOLF-GLADROW, D.A.; ZEEBE, R.E.; KLAAS, C.; KÖRTZINGER, A.; DICKSON, A.G. Total alkalinity: the explicit conservative expression and its application to biogeochemical processes. Marine Chemistry, v.106, p.287-300, 2007.

XINGYU, L.; GANG, Z.; XIAOQIANG, W.; LAICHANG, Z.; JIANKANG, W.; RENMAN, R.; DIANZUO, W. A novel low $\mathrm{pH}$ sulfidogenic bioreactor using activated sludge as carbon source to treat acid mine drainage (AMD) and recovery metal sulfides: Pilot scale study. Minerals Engineering, v.48, p.51-55, 2013.

YAMAGUCHI, T.; HARADA, H.; HISANO, T.; YAMAZAKI, S.; TSENG, I.C. Process behavior of UASB reactor treating a wastewater containing high strength sulfate. Water Resource, v.33, p.31823190, 1999.

YANG, Y.; LI, Y.; SUN, Q-Y. Archaeal and bacterial communities in acid mine drainage from metalrich abandoned tailing ponds, Tongling, China. Transactions of Nonferrous Metals Society of China, v.24, p.3332-3342, 2014. 
YARZA, P.; YILMAZ, P.; PRUESSE, E.; GLOCKNER, F.O.; LUDWIG, W.; SCHLEIFER, K.H.; WHITMAN, W.B.; EUZEBY, J.; AMANN, R.; ROSSELLO-MORA, R. Uniting the classification of cultured and uncultured bacteria and archaea using 16S rRNA gene sequences. Nature Reviews Microbiology, v.12, n.9, p.635-645, 2014.

ZAGURY, G.J.; KULNIEKS, V.; NECULITA, C.M. Characterization and reactivity assessment of organic substrates for sulfate reducing bacteria in acid mine drainage treatment. Chemosphere, v.64, p.944-954, 2006.

ZAIAT, M.; CABRAL, A.K.A.; FORESTI, E. Reator anaeróbio horizontal de leito fixo para tratamento de águas residuárias: Concepção e avaliação preliminar de desempenho. Revista Brasileira de Engenharia - Caderno de Engenharia Química, v.11, n.2, p.33-42, 1994.

ZAO, Y.; REN, N.; WANG, A. Contributions of fermentative acidogenic bacteria and sulfatereducing bacteria to lactate degradation and sulfate reduction. Chemosphere, v.72, p.233-242, 2008.

ZELLNER, G. STACKEBRANDT, E.; MESSNER, P.; TINDALL, B.J.; MACARIO, E.C.; KNEIFEL, H.; SLEYTR, U.B.; WINTER, J. Methanocorpusculaceae farn. nov., represented by Methanocorpusculum parvum, Methanocorpusculum sinense spec. nov. and Methanocorpusculum havaricum spec. nov. Archives of Microbiology, v.151, p.381-390, 1989.

ZHANG, B.; CAI, W-M.; HE, P-J. Influence of lactic acid on the two-phase anaerobic digestion of kitchen wastes. Journal of Environmental Science, v.19, p.244-249, 2007.

ZHOU, J.; XING, J. Effect of electron donors on the performance of haloalkaliphilic sulfate-reducing bioreactors for flue gas treatment and microbial degradation patterns related to sulfate reduction of different electron donors. Biochemical Engineering Journal, v.96, p.14-22, 2015. 